Suzana Lopes Salgado Ribeiro

\title{
Tramas e Traumas: identidades em marcha
}


Suzana Lopes Salgado Ribeiro

\section{Tramas e Traumas: identidades em marcha}

Tese apresentada ao Departamento de história da Faculdade de Filosofia, Letras e Ciências Humanas da Universidade de São Paulo, como requisito parcial à obtenção do título de Doutor.

Área de concentração: História Social

Orientador: Prof. Dr. José Carlos Sebe Bom Meihy

\section{São Paulo}

Faculdade de Filosofia, Letras e Ciências Humanas

2007 


\begin{tabular}{|l}
\hline 2007 Ribeiro, Suzana Lopes Salgado \\
Tramas e Traumas: histórias de vida e identidades em \\
marcha. - São Paulo: FFLCH/USP, 2007. \\
$392 \mathrm{p.}$ \\
1.Identidade, Experiência, Trauma \\
2. História Oral, História de vida, Narrativa \\
3. MST, Ritual, Mística, Marcha \\
\end{tabular}


Ao meu orientador,

Aos amigos que fiz no Neho e no MST, Aos meus pais,

Pessoas importantes para a construção de minhas identidades. 


\section{Agradecimentos}

Este é um texto que escrevo com grande prazer, pois o trabalho de pesquisa não é algo que se possa fazer sozinho. A troca de conhecimento é marca para uma pesquisadora que aprendeu seu oficio em um núcleo de estudos. Por isso é preciso agradecer...

Ao núcleo, que não é mais composto pelas mesmas pessoas, o que deixa saudade. Sinto falta das acaloradas discussões com Luiz Filipe e Fábio. Das boas conversas, acadêmicas ou não, com Fabíola e Luana. O movimento das mudanças constantes trouxe, entretanto, outros colegas com os quais pude aprender também. Assim, antes de qualquer outra colocação, gostaria de agradecer a todos que fizeram e fazem parte do Núcleo de Estudos em História Oral e, em especial, aos pesquisadores que lá estão sendo formados. A figura do Professor Sebe merece especial citação, não apenas por ter sido criador do núcleo e meu orientador, mas por acolher muitos sonhos.

Aos professores Zilda Iokoi e Leland McCleary pela leitura atenta deste trabalho no momento do exame de qualificação e pelas muitas contribuições e diálogos estabelecidos.

Aos amigos: Patrícia e Cristhian que me abrigaram no final do trabalho de campo; Andrea, que acompanhou parte da pesquisa e parceira de muitas conversas até a finalização desse texto.

Aos colaboradores, por sua disponibilidade em participar do trabalho e contar suas histórias de vida.

À minha família pela torcida e ao Ioka pelo companheirismo. 


\section{Resumo}

Este trabalho propõe um estudo sobre o processo de construção de identidades, no MST. A pesquisa de campo acompanhou o dia-a-dia da Marcha à Brasília, realizada em 2005.

O texto é composto por uma apresentação de oito narrativas, seguidas de uma descrição do trabalho de campo. Na segunda parte, apresenta-se uma explicação teórica e metodológica conceitos como, experiência, memória, narrativa e identidade, sempre tentando explicar como esses conceitos são relacionados com o fazer da história oral.

No interior das discussões surgem os embates em torno da construção das identidades dos membros do Movimento e a visão identitária gestada por suas lideranças.

Palavras Chave: história oral, identidade, experiência, exclusão, trauma, sem-terra, ritual, marcha.

\section{Abstract}

The purpose of this research is to look at the process of construction of identities inside the biggest social movement in the contemporary Brazilian society: the MST. The field work accompanied the day-by-day live of the March to Brasilia (Brazil's capital), that happened in 2005.

The theses text is composed by a presentation of eight live stories, followed by a description of the field word. The second part presents theorical and methodological approach on questions as: experience, memory, narrative and identity, always trying to explain how these procedures are related with the labor in oral history.

In the core of the narrative's interpretation is raised a debate involving the identities construction of Movement's members and the identity created by its leaderships.

Key words: oral history, identity, experience, exclusion, trauma, landless, ritual, march. 


\section{Sumário}

$\begin{array}{ll}\text { Introdução } & 10\end{array}$

Parte I - Narracões e narrativas: entre raizes e opções

1. Adelir 18

2. Ana Paula 31

3. Aquiles 57

4. Daniel 77

5. Elizandra $\quad 87$

6. Luis 105

7. Ronaldo 114

8. Wanderléia 126

$\begin{array}{ll}\text { Cap } 1 \text { - Passo a passo do projeto } & 145\end{array}$

Um início para essa pesquisa $\quad 149$

Trabalho de campo em marcha 152

Atos de estréia $\quad 157$

A caminho 166

$\begin{array}{ll}\text { Epílogo } & 167\end{array}$

Balanço de uma experiência $\quad 172$

Parte II - Memórias e identidades: para além de uma e de outra 176

Cap 2 - Memórias e narrativas: percepções negociadas 177

Sobre memória $\quad 183$

Memória: um debate contemporâneo 194

Narrativas: usos e práticas $\quad 199$

Uma possibilidade de diálogo 206

Desdobramentos no campo da história oral 212

Diversidade epistemológica: diálogos com a história oral 228

$\begin{array}{ll}\text { Cap } 3 \text { - Exclusão: uma história anterior ao MST } & 231\end{array}$

Semente no campo da inclusão 244

Narrativas testemunhais 246

Tornar-se cidadão $\quad 252$

Democracia dissimulada $\quad 260$

Cap 4 - Processos de identificação: mediações no MST 273

Jogos de espelhos: historicizando identidade 287

Muitas necessidades, múltiplas identidades 304

Ausências e emergências: subjetividades e identidades 311

Cap. 5 - Participação e atuação: processo de consolidação identitária

Simbologia sem-terra 
Paradoxos cotidianos: acampamentos, ocupações e despejos 337

Místicas: emblemas identificadores 342

"Revolta mística": tradição e transformação 348

Educação e formação: bandeiras de luta 358

Marcha, um ritual místico 364

Caminhos pessoais, marchas coletivas 370 Bibliografia

381 


\section{Introdução}

- O senhor poderia me dizer qual caminho devo seguir para sair daqui?

- Isso depende muito do lugar para onde você queria ir - respondeu o Gato.

Lewis Carrol - Alice no país das maravilhas

Marchar. Caminhar. Estes verbos explicam muito do que será escrito. Guardam o significado do movimento para se alcançar um objetivo, um significado que implica mudanças constantes, pois sem elas permanece-se igual e no mesmo lugar. Além disso, os verbos também definem tramas e traumas biográficos que guardam algo de comum e por isso ajudam a definir identidades. A marcha se transforma em metáfora da luta e da constituição do Movimento dos Trabalhadores Rurais Sem Terra - MST. Também se apresenta como modo de organização que prevê o diálogo, não se vendo como concluída. Assim, o Movimento Sem Terra e as identidades a ele relacionadas estão em contínuo seguir em frente, prosseguindo em suas ações.

A origem dessa tese repousa sobre a proposta de um estudo teórico sobre a prática de pesquisa desenvolvida ao longo de dez anos de trabalhos junto ao MST. Como resultado dessas questões iniciais, esse texto marchou em duas direções. Uma sobre as identidades que envolvem o MST, seu processo de constituição por meio de experiências. Outra a respeito da aplicação da história oral como forma de produção e análise, especialmente no que se refere à maneira de se memorizar e narrar algo e as relações estabelecidas entre sujeitos (entrevistador e entrevistado).

Destacam-se três conceitos para o fazer da história oral: mediação, ao propor um novo papel do pesquisador frente à comunidade selecionada para a pesquisa; colaboração, ao estabelecer preceitos éticos para o relacionamento com os entrevistados; e transcriação, ao supor uma interação entre os sujeitos envolvidos no 
processo de transposição do discurso oral para o escrito. Tem-se, assim, a constituição da narrativa, como ato de negociação das memórias pessoais e de luta, que baseada em uma experiência, tornou-se outra forma de construção de identidades sem-terra.

Os dois temas (história oral e identidades sem-terra) foram tratados de forma conjunta, primeiro porque muitas vezes a reflexão sobre a metodologia, envolve a análise do tema, e vice-versa; mas, mais que isso, porque experiência e memória são essências do narrar e também do identificar. Assim, teoria, trabalho de campo e interpretações não são (d)escritos separadamente, mas juntos, de forma a estabelecer sentidos entre todos.

Esta tese não tem a intenção de esgotar nenhuma discussão. Antes de mais nada, o que se pretende é apontar trilhas de pesquisa e reflexão sobre temas. Trilhas estas que devem ser alargadas em trabalhos futuros.

Com isso em mente, passou a ser importante explicar a realização das entrevistas e as interações propostas para que as narrativas encontrem-se da forma que estão. Além disso, apresentou-se outra narrativa, que tentou achar os sentidos do caminho de pesquisa. Esses textos compõem a primeira parte do trabalho, na qual se apresentam os resultados de construção das narrativas.

Trabalhou-se, inicialmente, com um universo de 47 entrevistas, realizadas durante a marcha nacional, que ocorreu de $1^{\circ}$ a 15 de maio de 2005. Desse universo inicial, foram selecionadas oito narrativas. Os colaboradores foram mulheres e homens, de idades e etnias distintas, oriundos de 23 estados brasileiros representados nessa última marcha nacional organizada pelo MST. Essas entrevistas foram feitas com a preocupação de entender como essas pessoas sentiam-se em relação a sua participação no movimento social. "Estar lá" com o grupo, marchando, marcou um posicionamento, que possibilitou a realização desse trabalho. Para quem estava preocupado em entender o processo de formação das identidades dos sem-terra, ter participado da marcha foi fundamental. A marcha é um dos momentos em que, ao 
mesmo tempo, constituem-se e afirmam-se identidades, principalmente uma identidade "oficial" que as lideranças do Movimento convencionaram chamar de identidade Sem Terra.

Neste caminho optou-se por iniciar pelos textos resultantes dos diálogos entre pesquisadora e entrevistados, as histórias de vida. Cabe aqui explicar por que é importante que os primeiros passos sigam as narrativas. Elas foram o ponto de partida para todas as reflexões presentes nessa tese. As narrativas são o material a ser lido e interpretado. Grande parte do trabalho de campo se concentrou em registrar esse conjunto de referências, para mais tarde constituí-lo e analisá-lo.

Como esse trabalho iniciou-se ouvindo os narradores, colocar algum tipo de análise sobre o que foi dito, antes de apresentar a conversa em si, seria uma inversão que poderia acarretar em prejuízos para a compreensão. Pareceu coerente conduzir o texto pelo mesmo caminho percorrido pela pesquisa, e ter o cuidado de, como se diz no campo, "não colocar o carro na frente dos bois". Essa é uma opção também ética, que tenta dar destaque ao diálogo estabelecido entre pesquisadora e sujeitos da pesquisa.

A opção feita reforça o compromisso assumido com essas pessoas de tornar públicas suas histórias e segue a prática de pesquisa do Núcleo de Estudos em História Oral - Neho/USP que enfatiza a importância das narrativas aparecerem integralmente, destacando que todo trabalho com as entrevistas deve partir de suas análises. Portanto, apresento as entrevistas em primeiro lugar e destaco que esse não é formato inédito, iniciativas parecidas estão presentes na produção dos pesquisadores Neho/USP, ao longo da década de 1990 e trabalhada no livro "Augusto e Lea". ${ }^{1}$

É importante destacar que esse movimento de valorização das experiências e dos sujeitos, base da noção de colaboração, não é um movimento isolado da história oral. As funções do trabalho de campo

\footnotetext{
${ }^{1}$ MEIHY, J. C. S. B. Augusto e Lea: um caso de (des)amor em tempos modernos. São Paulo: Editora Contexto, 2006.
} 
clássico vêm sendo mudadas nas humanidades e merecem destaque as discussões levadas à frente pelos antropólogos. Além disso, amplo debate vem sendo travado sobre as questões da subjetividade e das narrativas nas humanidades em geral.

Toda uma tradição profissional mostra sinais de adaptação, frente à valorização da experiência do sujeito e a emergência de normas explícitas de colaboração. ${ }^{2}$ Cada vez mais tal princípio mostra-se como central e faz-se presente em uma gama de projetos que conscientemente realizam pesquisa como parte da própria identidade e prática política.

Faz-se necessário também marcar que a noção de colaboração é "parceira" das noções de intervenção e de mediação. Ou seja, a colaboração se dá no diálogo, no qual a intervenção está presente por meio de uma mediação.

Nos últimos anos, a história vem incorporando as fontes orais em várias pesquisas. Prática essa que tem alimentado um debate teórico sobre métodos de pesquisa e seus desdobramentos quanto à produção do conhecimento. Esse é um passo fundamental para a compreensão de como as especificidades sociais e culturais podem ser expressas por esses meios e permite ainda uma melhor conceitualização da idéia de tradução cultural em contextos de comunicação e trocas culturais.

A experiência de campo com os colaboradores fez com que eu fosse muitas vezes questionada sobre a importância e sobre o processo de produção das tramas biográficas. Desses diálogos estabelecidos para a realização das gravações resultou uma relação marcada pela produção compartilhada de conhecimentos, que (des/re)orienta aquela anteriormente estabelecida entre pesquisador e "pesquisado".

O papel do pesquisador em um trabalho como esse se delineia na perspectiva de entender o movimento social e tentar explicá-lo. Para tanto foi preciso ocupar uma posição de fronteira entre os "de dentro" e os "de fora", posto que se algo foi compreendido, isso é resultado de

\footnotetext{
${ }^{2}$ MARCUS, G. E. A estética do trabalho de campo contemporâneo em Arte e Antropologia, apresentação no Simpósio Internacional - Tradução e percepção - Ciências Sociais em diálogo. Disponível em http://www.lisa.usp.br/simposio acessado em 20/09/06.
} 
uma participação no Movimento. Ao mesmo tempo, escrever essa tese é uma explicação que respeita normas externas. Assim, a própria pesquisa foi um processo constante de colaboração.

Ao longo da pesquisa em história oral a questão da autoria tem sido vista com suspeita. Enquanto, a história convencional considerava o documento como um instrumento científico, qualquer evidência de um caráter autoral era tratada como corrupção dos dados que o documento deveria fornecer. Afinal ele teria que ser imparcial e objetivo para conter a verdade. Quando este paradigma foi substituído por uma história dialógica e interpretativa, nos anos de 1980, a questão da autoria foi considerada suspeita por outro motivo: era importante "dar voz aos sujeitos" da pesquisa, e assim, por vezes, o pesquisador cedeu seu lugar. Para além desse modelo, defende-se a importância de uma autoria negociada e claramente assumida, por se acreditar em uma nova forma de produção de conhecimento.

Como resultado dessa visão, este trabalho é um texto intersubjetivo e ideologicamente posicionado, em que a história é vista como possibilidade de construção de conhecimento baseado em um jogo de linguagem, localizado no tempo e no espaço. ${ }^{3}$ As leituras e as interpretações, presentes na parte II, procuram mostrar como tais narrativas ajudaram a entender as possibilidades e os problemas da constituição de identidades e os usos da história oral como caminho para se compreender os elementos dessa constituição.

Identidades, para essa tese não é simplificação (fuga de uma discussão mais detalhada, ou fetichismo gramatical dos plurais que geralmente encerra o problema da multiplicidade de perspectivas). $O$ plural se justifica como tributo à diversidade, como indicador da existência de uma - identidade que pretende ser singular - forjada pelo Movimento - e de outras, plurais, as múltiplas e particulares identidades das pessoas que o compõem.

A intenção foi produzir um texto em sintonia com as profundas mutações vividas pela história após a publicação dos

\footnotetext{
${ }^{3}$ JENKINS, K. A história repensada. $3^{\text {a }}$ ed., São Paulo: ed. Contexto, 2005.
} 
trabalhos do filósofo e historiador Michael Foucault, que com sua obra questionou o documento como mera transparência da realidade, reflexo do real, ou meio de acesso direto a acontecimentos e personagens do passado. Os documentos que se apresentam nesta tese foram "lidos" como discursos que compõem e organizam o mundo, transformam e fazem parte do real, feitos por alguém, em um determinado tempo e espaço, com intenções específicas que justificam escolhas. E assim também essa tese deve ser lida. Entendo que essa(s) história(s) é(são) uma dentre várias possíveis.

Tal afirmação só é possivel ao se fazer um balanço histórico e retomar os conhecimentos produzidos por pensadores que compuseram grupos como a Escola de Frankfurt com sua "teoria crítica da sociedade", os Annales e seus desdobramentos em décadas posteriores na "Nova história". Por meio da produção de intelectuais como esses, diferentes modos de narrar a história passaram a existir e ser aceitos. As diferenças entre a história dos vencedores e dos vencidos são enfrentadas, de modo a desmistificar o processo de construção do conhecimento e dar visibilidade a "outras histórias". No caso dessa pesquisa, uma "história vista de baixo"4, e também uma história dos movimentos sociais. De qualquer maneira, trata-se de histórias plurais, construídas a partir de diversas interpretações que ora se entrecruzam, ora se contradizem ou sobrepõem, em constantes disputas de poder. Cabe a cada um decidir com quais concordará e quais combaterá, encontrando seus caminhos.

Procurou-se nesse trabalho dar conta desses desafios colocados à minha geração de historiadores, pontuando as escolhas realizadas, seguindo uma trilha apontada por Foucault:

O intelectual me parece atualmente não ter tanto o papel de dizer verdades, de dizer verdades proféticas sobre futuro. Talvez o diagnosticador do presente [...] possa tentar fazer as pessoas perceberem o que está para acontecer, exatamente nos campos em que o intelectual talvez seja competente. Pelo

\footnotetext{
${ }^{4}$ Sobre esse tema ver: THOMPSON, E. P. History from below. In: The times literary supplement, 7/4/1966, p.279-280; SHARPE, J. A história vista de baixo. In: BURKE (org). A escrita da história: novas perspectivas. São Paulo: Ed. UNESP, 1992, p.40.
} 
gesto mínimo que consiste em deslocar o olhar, ele visibiliza o que é invisivel, faz aparecer o que está próximo, tão imediato, tão intimamente ligado a nós que, exatamente por isso, não o vemos. ${ }^{5}$

Por fim, deve ser dito que muitas mudanças também aconteceram na forma desse trabalho e na arquitetura final de sua apresentação. Dessa maneira, não é possivel "uma" forma definitiva de apresentá-lo. Antes mesmo de acabá-lo acho que poderei ter pensado outra melhor e ele mudou várias vezes enquanto não foi definitivamente impresso.

\footnotetext{
${ }^{5}$ Dits et écrits (éditions Quarto) II, p. 594. Citado por ARTIÈRES, P. Dizer a atualidade: o trabalho de diagnóstico em Michel Foucault. In: GROS, F. (org). Foucault: a coragem da verdade. São Paulo: Parábola Editorial, 2004, p. 22.
} 


\section{Parte I}

Narrações e narrativas: entre raizes e opções 


\section{Adelir}

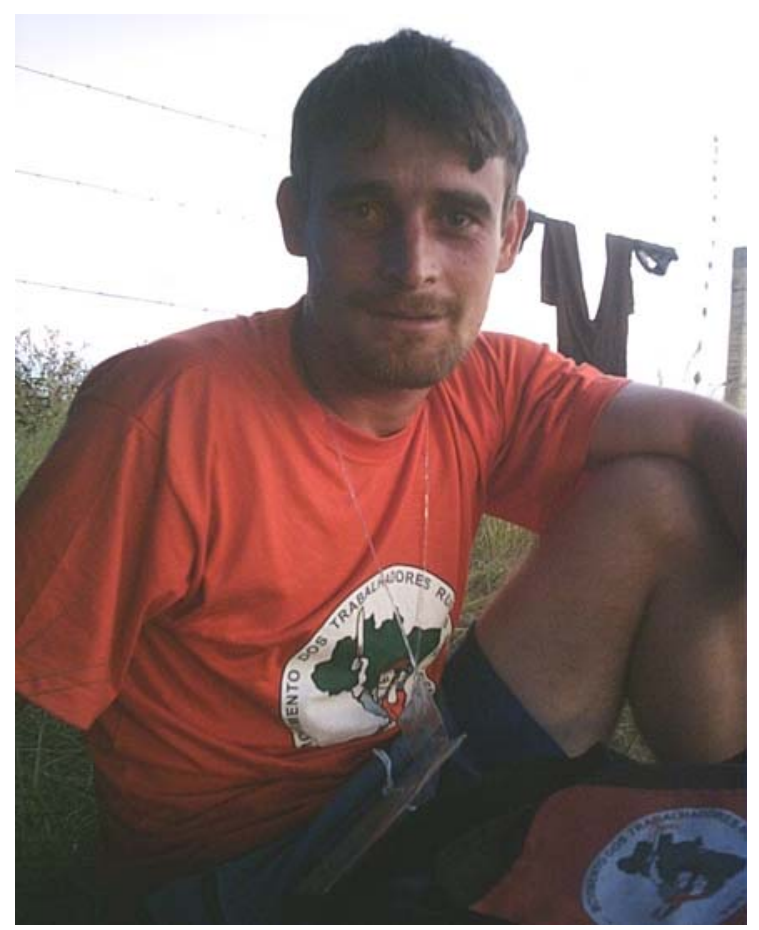

Preocupado com o que ia ser falado, Adelir fez com que a gravação parasse várias vezes. Durante esse tempo conversávamos sobre o que seria falado novamente. Afinal, sua posição dentro do Movimento exige, de suas palavras, cuidado e comprometimento. Embaixo de uma barraca pequena de lona azul, sentados na grama conseguimos registrar essa narrativa e dar algumas risadas. Entrevista gravada em 15 de maio de 2005. 
Acho que minha vida mudou muito. A gente costuma dizer que se hoje tem a terra, o local para plantar, a vaca para tirar o leite, a casa para morar... tem tudo isso porque a organização fez com que tivesse.

Tá gravando já?... Então, meu nome é Adelir de Lima. Moro no assentamento Nova Esperança no município de Pitanga, Paraná. Nasci em Santa Helena, no Oeste do mesmo estado. Sou de origem do campo. Sou filho de família pobre. Somos dois irmãos.

Desde pequeno ajudava com alguma coisa na roça. Mesmo assim estudei. Tenho o primeiro grau completo. Gostava, mais ou menos, de estudar. Sabe como é! Na verdade, quando estava com 15 ou 16 anos, o trabalho exigia um pouco mais, então parei. Também não estudei mais por falta de capricho!

Quando terminei o primeiro grau, a escola para onde eu teria que ir era longe, em torno de 25 quilômetros. O ônibus que pegava para levar saía seis horas da manhã e voltava duas horas da tarde, então ocupava praticamente o dia todo pra estudar. Isso também dificultou e tive que parar. A outra escola era mais próxima, não gastava tanto tempo. $\mathrm{Na}$ verdade, eu estudava à noite e podia trabalhar durante o dia.

Meus pais sempre trabalhavam de agregado, na terra dos outros, fazendo a meia. Mas foi um muda pra cá muda pra lá... Até os dez anos, percorremos vários municípios, ali do Oeste e Sudoeste. Sempre tinha vários problemas. Por exemplo, trabalhava um ano, o patrão mandava embora e tinha que ir para outra terra. Na família, devido a tudo isso, tinha alguns problemas. Meu pai tomava bastante... Minha mãe e ele se separaram. Eu tinha 11 anos de idade. Aí fomos morar com o meu avô. Sabia que não podia ficar ali. Então, tinha um acampamento e com a ajuda do meu avô fomos para lá. Acampamos e depois de um tempo, fomos assentados, em 1992, nesse lugar que estou até hoje.

A ida para o acampamento foi uma decisão da minha mãe. Mas, na verdade, foi meio que uma contribuição nossa também. Como 
vivia no campo o sonho era sempre ter um pedaço de terra, para trabalhar, morar e construir alguma coisa. Então também contribuímos para que ela tivesse a coragem de ir. O fato é que o Movimento não era tão conhecido como hoje, era o início do Movimento. Faz 16, 17 anos.

Dos dez para os 11 anos, o meu tempo foi o acampamento... Antes era meio sozinho. Geralmente a fazenda era longe... Só brincava com meu irmão. Depois mudou. No início, era um acampamento que tinha 800 famílias. Com o tempo foi dividido, fiquemos num grupo menor, mas sempre era um grupo que tinha bastante pessoa, bastante criança. Já participava das discussões e das reuniões desde pequeno.

Lá montamos um grupo coletivo. Trabalhamos nesse grupo durante dez anos. Uma das primeiras atividades que saí do assentamento foi em 1997 para a marcha, que saiu de São Paulo e veio à Brasília. Foram dez anos de cooperativa, então foi dividida. Por uma série de questões. Uma que o povo tem uma cultura ainda do "teu" e do "meu", e não do "nosso". Por mais que o nosso também tenha o "meu", eles acreditam que só o "meu" seria melhor. Mas foi uma experiência muito boa para mim e para todos que participaram da cooperativa, do coletivo. Muita coisa foi formada nesse tempo... Então há três anos faço parte também da Direção Estadual, de uma brigada de 500 famílias.

Acho que minha vida mudou muito. A gente costuma dizer que se hoje tem a terra, o local para plantar, a vaca para tirar o leite, a casa para morar... tem tudo isso porque a organização fez com que tivesse. Lógico que cada um de nós fez a sua parte, mas quem possibilitou foi ela. Não conseguimos imaginar como seria fora dela. Com certeza, as dificuldades seriam muito maiores. Como eu colocava que houve a separação do meu pai e da minha mãe e que a gente era pequeno... Na cidade, não teria nenhuma possibilidade da nossa mãe ter dado uma condição de vida melhor para nós, do que conseguiu no Movimento. Porque dentro do Movimento além de tu estar vivendo um pouco na terra em que era acostumado a viver, o conjunto, o 
acampamento, as pessoas que te cercam também contribuem para educação, para formação, para o crescimento... Às vezes, lá na cidade, não teria isso. Se a mãe fosse trabalhar de empregada certamente a gente iria ficar sozinho. Quando fomos para o acampamento, eu tinha nove... meu irmão é dois anos mais novo que eu.

Uma das coisas que contou para a gente ir para o acampamento foi que tinha aquele sonho de ter a terra, que foi iludido pelos patrões meio que a vida inteira. Quando a gente já conseguia entender, sempre que ia trabalhar com patrão, ele falava que quando saísse de lá ia ajudar nós a comprar um pedaço de terra. Meu pai, minha mãe passavam de um patrão para outro e isso não acontecia. A outra das coisas é que o Movimento apresentava uma opção, uma possibilidade de ter o pedaço de terra. Isso fez com que a gente ajudasse ela a ir, e a acreditar que isso era possivel.

Logo que chegamos no acampamento tinha algumas coisas que a gente pensava que era diferente. Mas também a questão de adaptação na época foi bastante fácil, até em função da gente ser criança. Era até mais divertido viver no acampamento do que antes.

A vida no acampamento é sofrida, mas ao mesmo tempo não é sofrida... É o exemplo aqui da marcha. Por mais que monte o barraco, ponha o colchão no capim, enfrente um sereno... ao mesmo tempo que tem esse sofrimento, é um momento divertido! É um momento que tu olha para o companheiro e vê que ele está mais molhado que você! Tu olha para o companheiro e vê que o torrão que ficou embaixo dele, o carocinho embaixo do colchão lá é maiorzinho do que o teu. E faz a caminhada. Se está doendo o pé não é só teu. Acho que cada pessoa, por mais que tenha as dificuldades, está acreditando numa coisa melhor, e não só para ele, mas para a sociedade como um todo!

As coisas dificeis ficam escondidas atrás das boas. O que parece dificil fica escondido atrás do que tem de bom, e isso em todas as lutas do Movimento: o acampamento, a marcha... 
Na verdade, nós acampamos primeiro no pátio de uma igreja. Lá nós ficamos um período de seis meses. Quando entramos no acampamento teve uma duração maior e depois, em 1986, ocupamos a fazenda Padroeira, no município de Matelândia, Paraná. Essa ocupação foi feita por 800 famílias. Esse acampamento, que não lembro quanto tempo durou, não conquistou área para o assentamento. E todos os grupos ali, como eram de vários municípios, foram saindo para um lado e para o outro. Tanto que hoje tem gente daquele acampamento quase em todo o estado do Paraná... no Noroeste, no Centro-Oeste, no centro... em todas as regiões.

Nós saímos dali e fomos para Castro, mais no Sul do Paraná, entramos numa área, mas também não conseguimos ali. Depois disso, fomos para Pitanga, já em 1987, em 1988. Só conseguimos o assentamento em 1992. Já estava com dezesseis anos.

Então, foram cinco anos nesse ocupa-sai, ocupa-sai. E, na verdade, sai com aquele sentimento... Porque, quando ocupa a área, acredita que ali vai ser a tua terra. O local que vai sair o assentamento e sonha com toda uma infra-estrutura... Então, tem essas!... Mas também tu - acreditando que para conquistar a terra tem que continuar - saía e ia para outra que tinha essa possibilidade. Mas ficava um sentimento doído. Acho que todos os acampamentos que as pessoas têm que sair por reintegração de posse, por despejos, fica a vontade de um dia ocupar a terra de novo. Um dia fazer lá o assentamento e a reforma agrária.

Já participei de despejo, mas não foi nas áreas que nós passamos. Quando saímos da Padroeira foi com um entendimento de que teria muita dificuldade daquela área ser destinada para o assentamento. Quando saímos de Castro, estávamos num grupo pequeno de famílias. Não tinha nem como resistir a um despejo. Então, não passei por despejo, no meu tempo de acampamento. Mas, como ajudei em ocupações... passei em outras situações, quando estava como grupo de apoio. 
Esse apoio é importante e fica bem claro dentro dos objetivos do Movimento Sem Terra. Lutar pela terra. Entender que os nossos problemas não estão resolvidos mesmo depois ter a terra, porque estão dentro de um conjunto bem maior. Nós estamos lutando com cinco, seis alqueires de terra, dependendo da região, contra um latifúndio. Nós não vamos conseguir competir com ele. É desigual. Além disso, é importante lutar pela reforma agrária para que te possibilite ter uma vida melhor, na terra que conquistou, e também para que as outras famílias sem terra tenham acesso a essa terra. Também acho que é a questão da sociedade diferente. A nova sociedade que queremos construir... Vamos conseguir se lutar pela reforma agrária e fazer a luta maior para transformar a sociedade que está aí!

É difícil falar numa entrevista assim... O gravador às vezes assusta um pouco...

Na marcha de 1997, a gente participou porque acreditava que é possivel fazer a reforma agrária. É possivel fazer uma sociedade melhor, em que haja terra e trabalho para todo mundo. Haja, então, uma vida mais digna para todos os brasileiros. E para todos os seres humanos! Um mundo melhor, diferente, em que a desigualdade não seja tão grande, pelo menos. E o que trouxe para essa marcha, de novo, foi isso.

Se for olhar pelas experiências de assentamentos que temos no país, dos que a gente conhece, diria que tem pessoas que quando foram para lá não tinham comida para comer. Sobreviviam da arrecadação de fora, da ajuda dos assentados e da sociedade. Hoje, tu vai na casa, tem o arroz, o feijão, a galinha, o porco, a vaca produzindo leite e uma casinha que construiu com o trabalho dele. Talvez não a melhor, mas é bem melhor que antes. Ele tem o espaço de viver. Não só o lote, mas uma comunidade também para participar. Ele recebeu contribuições e hoje consegue contribuir com as outras famílias acampadas e para que aconteça uma marcha do tamanho dessa. A marcha tem todo um custo, para cada estado, para cada brigada, para cada família. 
Quem não estava dentro, ainda não conhecia. Talvez aí esteja a importância da marcha. Quando nós organizamos a marcha além de botar os pontos de reivindicação, a nossa pauta, fazemos com que o Movimento seja conhecido pela sociedade, que passa a vê-lo de um jeito diferente. Passa a ver no Movimento uma possibilidade de se ter conquista, de se ter uma vida melhor, conseguir um pedaço de terra. E para outras lutas da cidade também, pelo emprego, pela moradia...

Estamos identificados: sem terra. Não sei como explicar, mas em função de todas aquelas questões que já foram colocadas... Lá no assentamento, nós temos que ser exemplo para outros que vão para luta. Temos que garantir isso. Se for assentado, não sair mais, para contribuir com os outros. Se não vai ser maior a dificuldade de formar novos acampamentos, de ter nova ocupação. Mas se o assentado contribuir para formar outros acampamentos, para fazer outras ocupações, vai ter mais facilidade porque é conhecido dentro do município. E muita gente olha para o assentamento e vê uma produção, vê a mudança que se teve no tempo de assentamento e se espelha neles. Um empurrãozinho do assentado facilita para que outro também vá fazer a luta.

Por exemplo, quando nós chegamos no assentamento, tinha uma realidade diferente. Todo mundo era pobre; pobres somos até hoje, mas antes, com muito mais dificuldade. E a sociedade em volta não conhecia. A gente até comenta, volta e meia, que muitas pessoas que moravam em volta de nós não davam nem carona para a cidade. Tinha que fazer 25 quilômetros a pé. Para ir e para voltar. Porque os vizinhos não davam carona para nós, porque não conheciam o Movimento. Mas hoje muitos filhos deles estão nos acampamentos. Por quê? Porque viram que o Movimento não era do jeito que eles pensavam, era diferente e viram no assentamento uma possibilidade, uma solução para os filhos deles também. A convivência mudou.O vizinho que não dava carona, hoje pega e também dá carona para os assentados. Hoje pega o maquinário emprestado dos assentados. 
Então acho que essa é uma tarefa nossa, de cada um ajudar a construir...

Acho que em todos os momentos estou identificado com o Movimento. Isso porque a partir do momento que foi para um acampamento, tudo que fizer, tudo que falar, passa a não ser olhado unicamente como tu. Passa a ser olhado como parte daquele assentamento ou acampamento. Pois faz parte daquele acampamento.

Quando saímos para uma mobilização do tipo a marcha que está acontecendo, ela tem a função de mostrar que é possivel fazer mudanças, e de reanimar o espírito como sem terra. Com discussão, com um trabalho de formação, nós pudemos fazer tudo, como por exemplo, a marcha de 10 mil pessoas para Brasilia. Quando discutia essa tarefa de fazer a marcha... dava dúvidas. Mas fomos fazendo a discussão, fomos criando condição, e estamos fazendo com uma infraestrutura melhor do que tivemos em marchas menores. Como a de 1997, que teve muito mais dificuldades, com relação à água, ao transporte, à alimentação, aos barracos... A coluna que participei saiu de São Paulo, no dia 17 de fevereiro e chegou em 17 de abril em Brasília. Teve um tempo e um caminho mais longo. Foram 1.200 quilômetros de marcha e um grupo menor, com 650 marchantes na coluna. Então a caminhada era maior, a infra-estrutura era menor. Andava o dia inteiro. Variava de 15 a 37 quilômetros, dependia do dia. Tinha os mesmos objetivos. Mas acho que as marchas que aconteceram em 1997 e 1999 foram o que deu suporte e a idéia de fazer uma com mais de 10 mil.

Então, se for olhar assim, aqui nós temos hoje um grupo de 12 mil pessoas! Dessas oito ou 10 mil no mínimo, eu nunca vi antes. Coloca todas juntas. Um montante de gente que dá a metade da população do município que eu vivo. Mas quais são as diferenças? Lá nós temos a polícia, a prefeitura e o fórum. Isso tudo para resolver os problemas que na verdade não conseguem resolver. E nós juntamos tudo isso sem ter polícia ou poder judiciário. Temos uma coordenação e uma representação de cada 40,50 pessoas que fazem parte de um 
grupo e não tivemos nenhum problema. Nós conseguimos organizar o banheiro, a comida, conseguimos fazer com que todos participem do estudo sem precisar ninguém mandar. Mas pela discussão e pela conscientização de cada um. Acho que o que oferece isso é a questão da discussão feita nos assentamentos. As pessoas que estão aqui têm a tarefa de representar os outros que ficaram no assentamento, no acampamento. E de chegar lá e, não prestar contas, mas transmitir a discussão, e as tarefas e os objetivos que se teve com a marcha.

Hoje, são poucos e muito poucos os que dizem que não vêm mais na marcha. Mas são muitos os que dizem que, se tiver, "eu venho de novo". Por quê? Porque além dele ter a conscientização do porquê está marchando, lá no assentamento foi feita toda uma discussão de todos os problemas que poderia ter. E conseguimos fazer com que esses problemas fossem menos do que estávamos preparados. Daí fica claro para nós que os problemas da sociedade, os juízes não vão resolver. Nem a polícia, nem a cadeia. Só o que vai resolver é a formação, a educação, se tiver trabalho, se tiver condições de sobrevivência para cada ser humano. Isso é que vai resolver os problemas da sociedade.

Acho que essa marcha ofereceu condições melhores que as anteriores. Uma das coisas: não temos mais que ficar uma tarde com sol quente como hoje embaixo de uma lona preta daquelas... É uma situação. Agora fica debaixo de uma lona clara como essa aqui... Por mais que essa organização teve um certo custo, que tem que considerar como investimento para a reforma agrária.

Antes a infra-estrutura tinha muito mais dificuldades. Não era questão da organização em si. É que a realidade do Movimento Sem Terra era outra, nunca se tinha feito uma marcha... Não sabia quais eram as dificuldades que ia se ter na marcha, ninguém tinha idéia disso. As condições financeiras eram dificeis, e são até hoje.

Mas certamente era mais dificil. E então foi o início... As outras pequenas serviram para trazer todas as preocupações e para se construir essa. Com os mesmos objetivos, e acreditamos que essa tem 
que se transformar em outra maior. Daqui a cinco anos tem que fazer uma com 50 mil, 100 mil, um milhão de pessoas!! Bem maior, porque essa aqui nós não vamos fazer as mudanças. Essa aqui nós estamos vindo até o posto para abastecer, para daí poder andar. É mais um pequeno passo. Tem muito para construir. E essa tarefa é de cada um de nós, dos 10 mil companheiros que estão aí. Acreditando que tem a tarefa de marchar, de fazer a caminhada até Brasília, de reivindicar a pauta de negociação que está colocada. Mas também tem a tarefa de voltar lá para o assentamento, o acampamento, o município, o estado e ajudar a construir coisas, condições, para fazer a mudança que é necessária, a reforma agrária, a nova sociedade.

Participei de cursos de formação. Mas, acho que essa questão da formação se dá também no dia-a-dia. Por exemplo, dava para separar por graus de escolaridade: tratamos a marcha como se fosse a faculdade porque é o momento que mais forma militante. Forma dentro de uma realidade diferente de onde está vivendo, o que possibilita enxergar realidades que ele não conhece. Por exemplo, em todos os espaços que nós passamos, foi visto pessoas morando embaixo do viaduto, pedindo esmola, as grandes favelas.

Como disse, a formação se dá também no acampamento. Desde que se começa o acampamento, além de ter o barraco e de estar lutando pelo teu pedaço de terra, está participando da reunião de como organizar a infra-estrutura: a segurança, a alimentação... Então isso também faz parte da formação porque ela exige que a pessoa não passe a pensar só no "eu", mas a pensar e discutir o "nosso". E tem momentos lá dentro do acampamento de estudos mais teóricos, juntando com a prática também do dia-a-dia. Tem uma coordenação que vê o todo do acampamento. Tem encontros da regional e da estadual. E tem vários cursos de formação política e técnica, que vai pessoas dos acampamentos e dos assentamentos. Hoje uma das tarefas é formar militantes que consigam ter o conhecimento técnico da questão agroecológica. Por quê? Porque se nós fizemos a luta pela terra, agora, tem que mudar esse modelo tecnológico. A nossa semente 
e a maneira de trabalhar a terra. Porque ao contrário disso, seremos novamente os futuros sem terra. Podemos não perder a terra para o banco, porque conquistamos isso, mas vão obrigar a deixar as áreas porque vamos nos endividar e não vamos ter condição para sobreviver no nosso lote.

Então, tem que trabalhar essa questão técnica para mudar isso, porque muitas vezes o nosso povo perdeu essas referências. Alguns até aprenderam um pouco com o agronegócio. Mas, por exemplo, se há 10 ou 15 anos plantava a nossa semente de milho, hoje nem temos mais a nossa semente. Perdemos, desaprendemos... e tem que resgatar isso.

Outra coisa que tem é o trabalho de formação com a sociedade. Apesar de ter uma certa deficiência aí. Ainda temos dificuldades, no Movimento, de fazer esse trabalho, mas sempre é feito. Acho que no momento que nós vamos fazer a reunião para que a família venha para o acampamento, participa gente que não vai vir para o acampamento. Mas mesmo que não venha, de uma certa forma, vai ficar conhecendo o Movimento. Alguma coisa do Movimento fica, vai ter a referência de um amigo que foi para o acampamento. O mesmo acontece com o trabalho com estudantes. Acreditamos que teria que trabalhar melhor essas questões da reforma agrária e do conjunto com a sociedade como um todo: a Igreja, os estudantes, o desempregado. Fazer com que cada um construa um pouco da história.

Sou casado. Eu conheci ela na sede da cooperativa nossa, a cooperativa regional. Ela é filha de assentado, só que de outro município, do Sudoeste do estado do Paraná. Eu tinha a tarefa de acompanhar a questão da produção de leite da cooperativa regional. Ela veio passear e eu conheci. Faz sete meses que estou casado, e ela está grávida de seis meses, de um piá. Meu primeiro!

Ela ficou em casa. Até porque teria a dificuldade de marchar... seis meses... Achamos melhor que ela ficasse. Quinta-feira, vou estar em casa. Estou contando... 
Mas é isso. Na verdade ficou dessa vez, vai ter que ficar da outra. Enquanto o menino não ficar sozinho, vai ter que vir junto, porque vai ter que aprender, também vai lutar por isso. Se nós estamos começando eles têm que dar continuidade. Porque não é só nós que vamos transformar. Mas são os futuros que vêm pela frente que têm a tarefa de fazer a mudança mesmo.

Se me perguntam sobre a melhor coisa que vivi, digo que na verdade não tem como separar uma. São muitas as coisas boas da vida. Eu acho que... Sou uma pessoa feliz.

Quanto ao pior, acho que também não dá para separar assim... Tem coisa que aconteceu que talvez são difíceis. Não só para mim, mas para um certo grupo de pessoas. Por exemplo, quando a gente fala dos despejos, que aconteceram na nossa região nos últimos tempos que foram bastante violentos... Ninguém quer viver aquilo. $\mathrm{O}$ que aconteceu num dos despejos nossos, foi a polícia dando muito tiro no meio de homens, de mulheres, de crianças, de velhos e tirando duzentas famílias de uma área que tu tinha certeza de que era improdutiva. Tinha consciência que era de uma pessoa, que se dizia proprietário, e que não depende dela para viver, nem para nada. Nem para explorar. Mas não basta dizer "não quero viver mais", e desistir, tem que lutar. Porque senão vai acontecer de novo. Mesmo lutando vai acontecer de novo, em outras áreas. Mas lutando pode ser que chegue o dia que não aconteça mais.

Eu trabalho na Direção Estadual. O estado do Paraná está todo distribuído em brigadas de 500 familias. Cada brigada tem um dirigente político, que é o responsável, para acompanhar as famílias. E todos os setores têm um responsável, para a questão da educação, formação, saúde, produção, frente de massa, e mais dois que não me lembro agora... Ah, comunicação e cultura. Então tem um dirigente e mais os sete companheiros que fazem parte dos setores estaduais.

As 500 famílias estão organizas em brigadas de 50, que tem que ter um coordenador e uma coordenadora. Um pouco na idéia de contribuir para a participação das mulheres. Porque tendo uma 
companheira como coordenadora, ela vai fazer com que haja mais participação de outras companheiras nas reuniões do grupo. $\mathrm{Na}$ brigada de 50 familias tem também um responsável, por cada setor desses que já foi colocado. E a brigada de 50 está dividida em cinco grupos de 10 famílias. Então cada cinco núcleos de base, de dez famílias,formam uma brigada de 50 famílias. E cada brigada de dez núcleos de 50 famílias, forma uma brigada de 500 famílias.

O dirigente da brigada de 500 famílias faz parte da Direção Estadual do Movimento. Então, no caso, é a minha tarefa fazer parte da Direção Estadual e acompanhar a brigada e os setores. Além de fazer parte da Direção, acompanho um pouco a questão da produção, principalmente do leite. $\mathrm{Na}$ cooperativa regional, que pega três brigadas de 500 famílias, trabalhamos a coleta do leite. Mas, já participei também do setor de formação.

Hoje, na verdade, não fazemos uma coleta da produção do leite de todas as famílias. Mas nós fizemos a coleta de uma brigada, por causa da localização dela. A produção deles varia. Mas chega em torno de 100 mil ou 140 mil litros de leite, por mês. A gente trabalha o leite que é uma questão que está se reforçando hoje. Todo mundo que está produzindo, está aumentando a produção, está pegando mais vacas para produzir mais. Tem também a produção da erva mate que é bastante forte. E dai tem o tradicional, a planta do milho, do feijão, do arroz e também tem a soja.

Quanto ao leite, até agora só fizemos uma coleta e repassamos para um laticínio, conseguindo um preço melhor. No passado teve uma discussão para nós montarmos um laticinio próprio. Mas aí tinha que passar pelo município e teve uns travamentos e não passou. Mas também, por mais que fosse montado, estaria montando dentro do sistema que está aí. A competição de mercado seria difícil...

Agora está bom o que eu falei. Acho que seria isso. 


\section{Ana Paula}

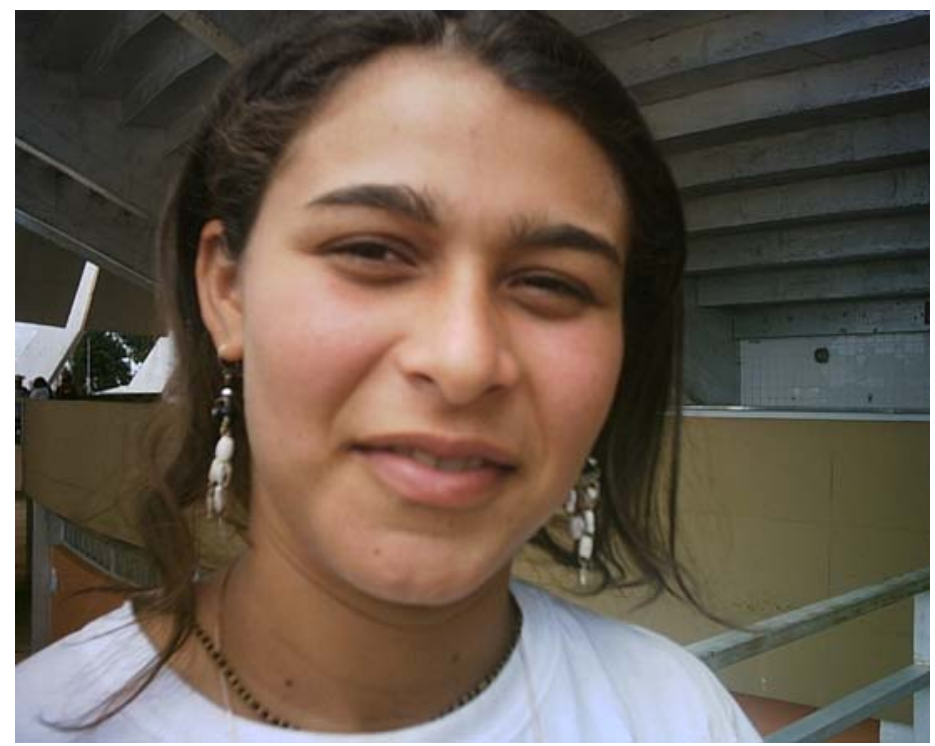

Ana Paula escolheu ser entrevistada logo no início da pesquisa. O que ora se apresenta é o resultado de três horas de conversa e de dois encontros. Cheia de detalhes, Ana Paula mostrava-se contente ao narrar suas experiências. Fato reforçado por ter me procurado no final da marcha para finalizar sua história de vida.

Entrevistas gravadas em 11 e 18 de maio de 2005. 
Hoje, eu sou muito feliz por ter tomado a decisão de ficar no assentamento, porque foi uma opção. Eu mudei de mundo!

Meu nome é Ana Paula Pinheiro Paiva. Nasci em 21 de fevereiro de 1985, no interior de Bacabau, uma cidade bem pacata e muito bonita do Maranhão. Uma das partes bem interessantes, que gosto de contar é como eu nasci. O que minha mãe passou. Qual foi a trajetória que ela percorreu para me parir. Era no sábado à tarde, quando vou falar me emociono. Ela começou a ter dor e nesse sábado tinha uma festa no interior próximo e minha mãe pela manhã brigou com meu pai, eles tiveram uma discussão feia. Ele foi para o jogo que tinha na parte da tarde, antes de começar a festa. E ele disse que ia para o jogo, e para festa. Minha mãe, pela manhã, pediu para ele não ir porque ela já estava sentindo algumas dores. Estava no inverno e para ir para cidade, tinha um igarapé muito fundo e muito grande. Aí ela começou a ter dor. A casa da minha avó, da mãe dela, ficava distante do interior que ela morava. Ela pediu para um menino ir lá, montado de cavalo. Ele foi e trouxe minha avó. Elas foram para Bacabau, atravessaram o igarapé, nadando, e ela foi para casa de um tio meu. Passou o resto da noite com dores e no outro dia pela manhã ela foi para o hospital. Lá ela sofreu muito pelo fato dela não conhecer ninguém. Estava só com minha avó e não tinha dinheiro de jeito nenhum. Ela comprou poucas coisas para mim, do enxoval.

Ela me teve com a maior dificuldade. Sozinha, só com minha avó. Às vezes, minha avó ficava lá fora também, passou muita fome porque ela não tinha dinheiro para comprar comida. Sabe que na cidade tudo é comprado e o hospital ficava distante da casa de meu tio. A relação deles, da minha mãe com ele não era muito boa. Ela passou dois dias no hospital. Meu pai foi lá visitar e ela voltou. Voltou para casa comigo! Aí começou nós...

Eu sou a caçulinha. Sou a última de quatro filhos. Aí começa a minha vida, os meus primeiros passos. Minhas irmãs e meu irmão 
cuidavam de mim. Minha mãe tinha muita dificuldade porque começou a luta dela. Ela gostava muito de participar da Igreja. Meu pai é MUITO fechado e muito machista! Não queria, de jeito nenhum, que ela participasse. E ela teve iniciativa. Disse "é isso que eu quero" e começou a se engajar na Igreja. Daí começa a trajetória dela. Nessa época, meu pai era bem rígido e brigava com ela. A relação deles não era boa. E até aí eu conheço porque ela me falou. A gente conversa muito.

Mas eu queria falar agora sobre o meu entendimento de vida. Ela mais meu pai foram embora para outro interior, que até hoje nós moramos. Na Bomba, no interior de Bacabau.

Eu quero explicar o porquê desse nome. Bomba é porque era uma terra indigena e tinha um poço muito grande e o povoado era bem grande nessa época. Só tinha um poço e as pessoas iam pegar água. Ao redor do poço, o pessoal encontrava um monte de bombinhas. Acho que deixadas pelos portugueses. É muito interessante. Achavam essas bombas antigas. E as pessoas começaram a falar: "Ah, tu vai para onde?” "Ah, vou pegar água lá na bomba”. Ai surgiu o nome Bomba.

Eu vou falar um pouco de como eu iniciei na escola, o meu estudo. Comecei com sete anos a ir para o colégio. É uma coisa bem interessante. Quem foi minha professora? Minha mãe! Acho engraçado isso. Minha mãe foi minha professora do primário, desde a $1^{\text {a }}$ série até a $4^{\mathrm{a}}$ série.

E, para chegar nisso ela... Tá!... Antes eu falei da participação dela na Igreja. Foi aí que ela despertou que ela tinha que estudar porque antes o meu avô não deixou ela estudar de jeito nenhum. Aí ela começa, fez a prova do Logos naquela época. Ela passou e ela começou a estudar o Logos. E nessa época meu pai viajou para São Paulo porque nossas condições de vida eram muito precárias. Aí ele viaja para São Paulo, porque lá, é como é falado, tem muitas oportunidades. Ele vai para São Paulo e deixa nós cinco: minha mãe e os filhos.

Nessa época era inverno, nós passamos muitas dificuldades. A gente às vezes só almoçava ou só jantava e a gente só não morreu de fome por causa do meu avô que ajudava a gente. E meu pai passou uns 
dois anos em São Paulo. Mas minha mãe continuou estudando. Todo sábado, ela tinha que pagar passagem para ir até a cidade fazer as provas. Ela estudava a semana inteira e no sábado ia fazer as provas daquele conteúdo. Então, um detalhe bem interessante é que para minha mãe para sustentar a gente e pagar essas passagens tinha que quebrar coco a semana inteira. Cuidava dos filhos, estudava e quebrava coco. A primeira professora do nosso povoado foi ela. Foi ela que deu os primeiros passos. Bem bonita a história da minha mãe! Eu começo a ir para escola com sete anos. Era uma emoção muito grande nesse dia... Ter aula com minha mãe! Ficava pensando, será como que é? A curiosidade, aí. Ela comprou o meu material, e acho que durante um mês antes eu pegava esse material e ficava olhando, achava muito bonito. Meu Deus que eu vou fazer desse material? Era um caderno, uma caneta e uma bolsa bem bonitinha .... E eu ficava olhando para aquilo... Todo dia antes de dormir eu pegava aquela bolsa e ficava olhando. "Vai chegar o meu dia de ir para escola!" Eu via todo mundo indo para escola. Ficava olhando às vezes na porta. "O que será que eles estão fazendo?" Mas sempre a porta ficava fechada e eu tinha a curiosidade. Tinha um momento, que é o recreio, e as crianças brincando, pulando... "Mas um dia eu vou ficar daquele jeito ali com meus coleguinhas". Eu não podia nem ficar com eles porque ficavam brincando com os colegas da escola. Eu ficava sempre de fora.

Foi o primeiro dia de aula, o dia esperado para mim. Eu me arrumei toda, tomei banho de manhã, coisa que não gostava de jeito nenhum! Aí a minha mãe me chamou e fez um cocózinho no meu cabelo. Ela pegava a xuxinha e amarrava o cabelo da frente. Mas eu tinha raiva! Não gostava, detestava quando ela fazia isso. Mas tudo bem, aí fui para o colégio. Aí a gente começou. Ela se apresentou e todo mundo foi se apresentando, porque eram alunos novos. Falamos sobre a vida da gente nesse dia. Foi um dia muito bom, que a gente brincou muito. No primeiro momento, eu gostei muito. Eu digo, iche isso é muito bom. E já no segundo momento eu não gostei, eu digo não, não gosto de estudar. Para mim, o primeiro dia, foi ruim demais porque 
chegou o momento de escrever no quadro, da gente prestar atenção. Eu imaginava que estudar só era brincar... Sempre fui muito sapeca, muito danada mesmo. E minha mãe, nos outros ela não batia de jeito nenhum. Como eu era filha dela, ela me batia. Não para os outros colegas de classe ver. Mas por trás dos bastidores, ela dava uns beliscões, puxava a minha orelha e às vezes dizia "quieta menina!", "se comporta menina".

Eu tinha muita raiva! Eu digo, “mãe, por que a senhora sempre me bate e não bate nos outros?" Ela disse: “não, tu é minha filha, os outros não são meus filhos, eu tenho o direito de te bater". Eu respondo: "não dona, você não tem direito de me bater". Eu sempre questionei isso. Não explicava o porquê, mas eu achava que aquilo não era certo de jeito nenhum. Ela me bater e nos outros não.

A gente com sete anos ia para a primeira série, passei três anos na primeira série para poder aprender a ler!! Ave Maria, a mãe disse que eu era muito ruda que eu não aprendia a ler. Ela falava: "menina, mas tu é ruda, os outros tudinho já passaram e tu ainda está nessa!" Aí chegou o ano que eu passei. "Agora eu vou me livrar da senhora" porque tinha duas professoras. Mas cadê? Eu não me livrei, não. No ano seguinte foi com ela de novo. "Caramba, vou apanhar de novo!" Até a $4^{\mathrm{a}}$ série estudei com minha mãe. Tive muitas lições. Cada dia, eu admirava mais minha mãe, a força de vontade e o jeito dela se relacionar com as pessoas. Ela foi conquistando o espaço dela. Hoje admiro muito ela por isso. Ela é uma lutadora mesmo!

Aí eu passei na $4^{a}$ série, e tinha que ir estudar num interior mais longe ainda onde tinha da $5^{\mathrm{a}}$ a $8^{\mathrm{a}}$ serie. Era no Brejinho que ficava a três quilômetros de distância. Eu tive a mesma curiosidade! "Como que vai ser? Aqui eu já sei, eu conheço todo mundo...”, eu convivia com todo mundo do povoado. Lá no outro interior eu não conhecia quase ninguém porque eu não saía de casa. Aí chegou o momento de nós irmos. Para ir, eu tinha que aprender a andar de bicicleta. E aí foi muito engraçado, até hoje eu sorrio quando lembro disso. Atrás de nossa casa tem um campo de futebol bem grande. Eu aprendi a andar de bicicleta 
nesse campo que tinha uma descida muito grande. Nós tínhamos uma bicicleta lá em casa que era do meu pai. O varão dela era bem alto. Não dava para mim porque eu era pequena, tinha treze anos quando fui fazer a $5^{a}$ série. Era muito magrinha, magricela mesmo! Mas eu aprendi a andar de bicicleta muito rápido. Eu peguei várias quedas no início.

Nunca tinha andado de bicicleta. Era daquelas bicicletas grandes, bem antigas que tem uma roda, um círculo dentro do varão. Colocava a bicicleta encostada na parede e punha o meu pé dentro para subir. Aí saía na bicicleta e caía demais. "Chega de cair, eu tenho que chamar alguém para me ensinar". A Andreia, minha prima, e eu fomos para o campo. Aí ela segurava a bicicleta para montar. E eu montava. E como ela era magrinha, ela não dava conta de sustentar a bicicleta. Aí a bicicleta terminava caindo, mas com isso eu aprendi a andar. Às vezes ela empurrava e a bicicleta descia com tudo, às vezes ela fazia de propósito só para me derrubar e ficar sorrindo!!! Eu digo: “Ah, gaiata!” Mas com isso foi bem legal foi bem divertido aprender a andar de bicicleta.

Começou meu primeiro dia de aula na $5^{\mathrm{a}}$ série. Nós éramos cinco colegas que tinham que estudar no Brejinho. Aí a gente foi. E nosso colégio era bem feinho lá na Bomba, só tinha duas salas. Só fedia a rato lá. Não tinha ninguém que limpasse o colégio, era nós mesmos quando chegava. Quando eu cheguei no povoado na entrada, tudo era muito bonito. As casas bem feitinhas, também era bem pacato, mas era bem organizadinho. Aí nós fomos para o colégio que era muito grande. Para mim era enorme, tinha quatro salas. E tinha um pátio muito grande, tinha umas árvores bem bonitas. Tinha espaço para gente correr, brincar. Tinha um corredor enorme. E a gente colocou a bicicleta na calçada, na frente do colégio, a gente sempre jogava as bicicletas.

Tá, eu vou falar primeiro de como foi. Aí eu entrei na escola, me encantei com o colégio. Bem limpinho, as paredes brancas de tijolo, de telha. E meu colégio antes era uma casa de taipa. E eu fiquei encantada com a escola e os colegas que eu conheci. Eu sempre fui uma pessoa de me entrosar rapidinho com as pessoas. A gente 
começou, e no princípio eu achei muito pesado estudar. O conteúdo era pesado. E tinha umas professoras rígidas, como a Dona Graça. Mas tinha umas professoras muito boas que ajudavam, como a Dona Pastora, professora de Matemática. A Dona Graça era profesora de Geografia. Rígida, era diretora e professora ao mesmo tempo. Era gordinha, eu lembro como se fosse hoje às vezes a gente pegava briga, discutia. Eu nunca fui uma pessoa de falarem comigo e eu ficar só ouvindo. Se eu tivesse errada eu ficava na minha, agora se eu tivesse certa eu ia para o enfrentamento mesmo. E ela sempre falava: "menina, só tu mesmo que tem papas na lingua e vem me enfrentar". Sempre falava isso para mim. E eu era muito danada na escola, brincava, puxava um puxava outro e enfrentava ela. Mas só que uma vez ela disse assim: "eu vou te deixar reprovada ainda por causa das suas molecagens". Eu digo: "pode deixar". Mas ela não deixou, porque eu sempre tirava nota boas na matéria dela, que era a matéria que me preocupava mais. Aí no decorrer do ano a gente percebeu que deixava nossas bicicletas na frente da escola e não dava certo. Os meninos tiravam o pito, a tampinha do pneu da bicicleta. Aí quando a gente saía da classe estava esvaziado o pneu. Às vezes a gente até chorava porque não sabia onde ia encher. Depois a gente descobriu uma oficina, e sempre levava lá. Tinha uma colega, a Alcilene, que morava lá no Brejinho mesmo. Aí ela disse: “oh, Ana Paula, coloca a bicicleta de vocês lá em casa". A Dona Anita era a mãe dela. Começou a colocar a bicibleta lá. A gente se tornou uma família. Nós éramos cinco e chegava na casa dela e ela tratava a gente como filho. Até hoje a gente tem essa relação bem boa. Às vezes eu vou na casa dela visitar.

A gente saía do colégio morrendo de fome, não levava nem um dinheiro para comprar lanche. Às vezes encostava lá na casa dela, sempre tinha alguma merenda, um suco, alguma coisa para oferecer para gente. Tinha merenda no colégio, mas era vendida. A gente saía de casa às cinco horas, todo dia de manhãzinha. Chegava seis e meia na escola. Sempre levava roupa para trocar porque às vezes chovia, levava os livros dentro da bolsa, mas numa sacola, para não molhar. 
A gente, no período do inverno, tinha muita dificuldade. Era uma lama que grudava no pneu da bicicleta. Não dava para andar de bicicleta, a gente tinha que ir a pé então ficava mais dificil porque de bicicleta era mais rápido. E a pé, a gente vinha meio dia com fome, mas era bom, vinha brincando, cantando. Era muito bom, a vinda! Quando a gente ia, todo mundo calado. Agora quando a gente vinha, porque a fome era tão grande, que tinha que fazer alguma coisa para esquecer.

Chegava em casa à uma hora quando voltava a pé. Às vezes, doze e meia, quando era de bicicleta. A gente fez isso até a $8^{a}$ série nós juntos, a nossa galerinha. Tinha ano que a gente estudava de manhã, tinha ano que a gente estudava a tarde. A $5^{\mathrm{a}}$ eu fiz pela manhã, a $6^{\mathrm{a}}$ à tarde, a $7^{\mathrm{a}}$ pela manhã e a $8^{\mathrm{a}}$ à tarde. Eu nunca fiquei reprovada nenhum ano. Eu me esforçava porque era muito difícil ir para lá. E eu pus na minha cabeça assim, "cara, eu vou para lá todo dia, tenho a maior dificuldade então eu tenho que estudar e passar". Sempre minha mãe me cobrava isso.

$\mathrm{Na} 5^{\text {a }}$ série meu pai já estava em casa. Ele passou só dois anos em São Paulo. Ele sempre mandava algum dinheiro para minha mãe para ajudar nas despesas da casa. Aí ele voltou para casa e nossa vida melhorou. Minha mãe trabalhava em dois horários. O dinheiro era muito pouco. Mas meu pai fez outra casa para gente. Nossa casa era bem feinha, bem pacata mesmo! Nossa casa ele fez de barro e cobriu de telha porque antes era de palha. Isso para nós foi ótimo! Foi um avanço muito grande financeiramente. Meu pai trabalhava na roça. Mas essa terra era do fazendeiro. No povoado tinha umas cem famílias na época. Nós não tínhamos terra, ele doou uma parte para gente plantar, todo o ano. Para usar a terra, tinha que pagar uma porcentagem da produção.

Todo ano, meu pai plantava o arroz e o feijão. Nunca eles plantavam mandioca porque isso ia dar prejuízo para o fazendeiro. Plantava o arroz e o feijão porque era uma coisa mais rápida e a mandioca não, dura mais tempo. Em relação à farinha a gente sempre tinha que comprar no outro povoado. 
Aí eu terminei a $8^{a}$ série. Estava tendo uma discussão no povoado sobre o que ia fazer com todos os estudantes. Porque a gente sabia que todo mundo não tinha condição de ir estudar na cidade. Eram quatro turmas de $8^{a}$ série. O presidente da associação e alguns representantes dos povoados próximos fizeram uma reunião para discutir com as lideranças o que fazer. "Nós temos que chamar o prefeito e o secretário de educação para discutir com eles o que vai ser desse povo". "Essas pessoas que terminaram a $8^{a}$ série vão parar?" Aí dessa discussão a promessa deles era que ia ter o segundo grau, o ensino médio. Mas só que a gente não sabía com certeza. Nós não tínhamos certeza de que isso ia acontecer mesmo, sempre estava uma pergunta no ar. Eu tinha dezessete anos.

Minha irmã mais velha já estudava em Bacabau na casa da tia. Minha tia, irmã da mãe, era casada. E os outros irmãos estavam estudando em Brejinho. Aí nós sentamos e conversamos. Meu avô, pai da minha mãe, que morava no povoado tinha uma casa bem pequenininha em Bacabau que estava alugada. Eu perguntei para mãe, "nós vamos ficar esperando, nós vamos para Bacabau estudar, como é que vai ser?" A gente discutiu sobre isso, eu disse: "para casa da minha tia eu não vou porque lá já tem muita gente. Não dá para gente ir, todo mundo para casa dela". Aí ela chamou meu avô e discutiu com ele que nós tínhamos que morar na casa dele porque não ia parar de estudar de jeito nenhum. E ele aceitou. A gente foi para lá morar os três. Eu, Paulo, meu irmão, a Fabiana, minha irmã e minha tia Nena, irmã da mãe. Ela tinha uns vinte e cinco anos. Era uma pessoa mais velha, de confiança deles, para cuidar da gente, para acompanhar nesse processo.

No início, nós tivemos muita dificuldade na questão financeira, de sustentabilidade mesmo, porque nós não tínhamos condição. Nós tínhamos o arroz e o feijão que meu pai mandava. No princípio nós sofremos muito porque não era acostumado. Ali a gente ficava preso, não saía para lugar nenhum. Apesar de ter colegas na escola mas a gente ficava presa. E eu chorava muito, principalmente 
nos finais de semana porque não tinha nada para fazer. Eu queria ir para o interior. "Eu quero ir para casa, eu quero ir embora". Quando a minha mãe ia visitar a gente eu sempre dizia para ela, "mãe, não vou agüentar de jeito nenhum". Tinha dia que, meu Deus do céu, lá em casa não tinha nada para gente comer mesmo. Só o arroz e o feijão. A gente não precisa só de arroz e de feijão para se alimentar. Sofremos muito. Aí tinha uma amiga da mãe que disse: "Neide, tem uma amiga minha que está precisando de uma pessoa para trabalhar na casa dela". Aí a mãe conversou comigo se eu não queria ir para lá porque eu sabia das nossas condições. Então ela falou: "Ana Paula, tu sabe que lá vai se alimentar melhor. Tu vai trabalhar, vai ganhar algum dinheiro para comprar alguma coisa que está precisando. E tu também vai ter teu espaço para estudar". Aí eu aceitei e fui para a casa da Maura e do Zé Coutinho. E meus irmãos ficaram na casa passando uma barra.

Eu estudava na parte da tarde e trabalhava pela manhã. Tinha que passar o pano na casa todinha que era ENORME! Tinha limpar os móveis, os banheiros, fazer a faxina. Trabalhava só na limpeza da casa. E eu tinha que dar conta até doze horas. Às vezes eu acordava cinco horas da manhã, começava a trabalhar para doze horas estar tudo pronto. Mas sempre, doze horas estava tudo pronto. Eu fazia de tudo para não perder a aula de jeito nenhum. Aí eu ia para o colégio. Também passei muita dificuldade na escola. Tive vários problemas de depressão. Tinha uma professora que eu hoje lembro muito dela, a Margarete, professora de literatura. Ela também atua, ela é do PT. E ela me acompanhou muito. Eu acho que por isso hoje lembro dela, porque ela falava dessas outras organizações que eu não conhecia.

Quando eu voltava da escola tinha que apanhar a roupa do varal e colocar no guarda-roupa, dobrar a roupa todinha. E à noite eu tinha que esquentar a comida deles. E quando eu terminava isso, já estava cansadona. Às vezes pegava meus livros e ia estudar, se tivesse alguma atividade para fazer. Eu passei seis meses na casa dela, foi muito bom, aprendi muito. Daí comecei a dar mais valor para minha mãe, para minha família. O dinheiro que eu ganhava, apesar de ser 
pouco, dava para minha mãe e ajudava também na despesa de casa. Enquanto isso meu irmão estava fazendo magistério e minha irmã também. A Fernanda, a mais velha, ela viajou para Serra dos Carajás, para casa da irmã do meu pai, ela estava estudando e trabalhando para lá também. Daí a gente começou a se alinhar mais, a se achar porque as dificuldades eram enormes. Eu passei seis meses na casa da Maura e não agüentei mais.

No início, eu arrumei um namoradinho na rua. O nome dele é Rômulo. Ele era evangélico. E nessa época, quando saí da casa da Maura era carnaval. Eu estava com muita vontade de sair, de me divertir. E como tinha bastante colegas, a gente se juntava e ia para o carnaval, era numa pracinha bem pertinho lá de casa. Eu passava lá, em frente à casa dele, que era pertinho da minha, uns quinhentos metros. Quando eu passava lá, ele sempre estava sentado olhando o pessoal passar. Uma vez fui comprar um biscoito no final da rua, onde tinha um comércio. Eu vinha sozinha, ele estava sentado na calçada com o irmão dele na frente da casa. Topei numa pedra, agachei e passando a mão na minha perna, ele perguntou se eu queria ajuda. "Não, precisa não! Aí começou eu a conversar com ele. Um dia teve uma chuva enorme! E pensei: "Vou banhar na chuva". Estava banhando na chuva e ele e os irmãos dele estavam num alpendre na frente da casa dele. Sempre que eu passava, falava com ele, porque eu só conhecia ele. Os irmãos dele disseram assim, "vai lá cara, vai banhar na chuva com ela!". Aỉ ele foi. Por livre e espontânea pressão dos irmãos dele!! A gente conversou um montão, e ele perguntou onde eu morava, de que família eu era. E os avós dele, a família do pai dele morava bem pertinho do meu interior num povoado que chama Boa Vista. Ele ia lá em casa. Um dia a gente estava sentado lá, conversando, e de repente ele me deu um beijo.

Foi então que começou o nosso namoro. Os três anos do ensino médio, que passei em Bacabau, a gente namorou. E ele sempre me ajudou a enfrentar os problemas. A família dele tinha boa condição financeira. Mas teve momentos no nosso relacionamento que foi bem 
dificil. Como eu era muito jovem, não pensava como penso hoje. Aí eu namorava com outros garotos na escola. A família dele é muito conservadora. E eu sempre ia na casa dele, a família dele todinha conhecia até a minha família porque ficava muito próximo os interiores. Eles souberam que eu tinha ficado com um menino da escola. Foi uma confusão! A família dele pediu para ele terminar comigo. Aquela história que "meu filho não vai namorar com mulher sem vergonha". A gente terminou. Passou uns quinze dias afastado, mas depois a gente começou a namorar de novo. Desde aí, a gente nunca, nunca mais terminou. Durante esses 3 anos estamos namorando direto. Ele foi meu primeiro namorado e eu também fui a primeira namorada dele. Bem interessante mesmo. Aí tá, eu terminei o terceiro ano.

Um ano antes o meu pai foi visitar minha bisavó numa cidade que se chama Igarapé do Meio. E nessa época estava tendo trabalho de base. Até quem estava lá era o Noé, que faz parte da Direção Nacional da frente de massa. E eles estavam fazendo trabalho de base numa fazenda que se chama Flor do Vale. E coincidiu bem na época que meu pai foi visitar. Ele participou de uma das reuniões. E foi participando até quando ele despertou. Gostou muito do trabalho e decidiu que iria fazer a ocupação junto com o pessoal que estava lá. Ligou para minha mãe e falou que ia ficar. Ele participou da ocupação dessa fazenda, que não teve muita repressão por parte do fazendeiro. Foi uma coisa bem tranqüila. O fazendeiro até queira mesmo vender a fazenda. Ele passou dois anos morando sozinho... Eu estava na cidade, minha mãe na Bomba e ele lá sozinho, acampado. Foi um momento assim, que nossa família desfacelou. Foi uma divisão muito grande! Para gente se reunir tinha muita dificuldade. Passou um tempão para reunir todo mundo.

Nesse momento ele entrou no MST. Mas eu nem sabia o que era. Às vezes ia para casa na Bomba e ele estava lá. Ele falava e eu sempre dizia: "Ah papai, parece que tá é doido". "Ficar com esse povo, que não tem nada o que fazer!". Ele participou de um ato em São Luiz e trouxe umas fotos dos companheiros que estavam nesse ato. Todo mundo vestido, com a blusa do MST, blusa branca e as letras em 
vermelho M S T. Achei muito bonito. Todo mundo com bandeiras, debaixo de uma árvore. Era assim umas trinta pessoas. Eu achei muito bonito e eu comecei a perguntar para ele como que era. Ele sempre foi trancadão, mas falou: "Isso daí é muito organizado, Ana Paula, é muito bonito o trabalho que eles fazem”, mas ficou por aí. No último ano a minha mãe conversou comigo: "Ana Paula, agora tu vai ter que ir morar com teu pai”. Eu não queria de jeito nenhum pelo fato de eu estar namorando, estar bem integrada, tinha muitos amigos, já gostava muito de Bacabau. Acho que foi um choque na minha vida, quando ela falou isso. Deus me livre! As condições que meu pai falava que vivia lá. Pensei "não vou de jeito nenhum, já basta o que no princípio nós sofremos em Bacabau".

Minha mãe disse: "Ana Paula, tu vai ter que acompanhar teu pai, porque não tem ninguém para ir." Meu pai sempre foi bem doente, tem crise de gastrite. Eu falava: "Por que não vai a Fabiana?" Mas ela estava terminando o magistério que tinha um ano a mais que o curso que eu fiz e tinha terminado. Era muito dificil, mas eu tinha que ir. Se meus pais mandassem eu tinha que fazer. Numa noite estava conversando com o Rômulo e falei para ele: "Rômulo, vou ter que viajar no dia doze". Isso era no dia 12 de dezembro de 2002. E ele disse "tudo bem, tu não pediu a minha opinião tu já falou que ia viajar”. No dia 12 arrumei as minhas coisas e fui. Cheguei na cidadezinha, procurei onde que era a casa da minha tia. A cidade é bem pequena, dez mil habitantes, todo mundo conhece todo mundo. Fiquei na casa da minha tia Maria, a irmã da minha avó que é mãe da minha mãe. Perguntei: "Tia, como é que eu faço para ir onde o papai está? Ela disse: "É bem pertinho, um quilômetro da cidade para o assentamento”. Deixei minhas bolsas lá e fui.

Descobri que primeiro eles ocuparam a sede da fazenda. Como a área era muito grande e estava tendo muita ocupação pelo sindicato, eles estavam com medo. Por isso umas pessoas foram para o início da área, umas ficaram no meio, e outras no final da área. Meu pai estava com esses que ficavam no final. E nessa época que eu fui para lá tinha 
saído o crédito habitação, já tinha as casas. Fiquei numa casa morando com ele.

Era inverno e lá é uma baixada, que nessa época é um aguaçeiro, uma lama que dava bem na canela da gente. Olhei aquilo lá e pensei: "Ó meu Deus do céu, eu vou morar aqui?!" Eu me desesperei quando eu olhei para aquilo ali. Um monte de crianças com um buchão, com aquela barrigona, toda suja. As mulheres muito maltrapilhas mesmo... Antes vivi no povoado, na Bomba, mas as condições eram bem melhores que as de um pré-assentamento. Foi um choque muito grande, um choque cultural apesar de ser no mesmo estado, mas a cultura é diferente. A questão de relacionamento com as pessoas mesmo, porque sabe que num assentamento tem pessoa de todo o jeito, do Sul e do Norte do estado. Vai juntando as pessoas daquelas redondezas. E tinha umas pessoas que falavam bem baixadero mesmo... eu acho muito bonito. Quando eu cheguei, eu conversei com essa senhora. Ela arrasta mesmo o sotaque da baixada. Ela falava e eu sorria!

Cheguei lá perguntei onde que meu pai, o Artur, morava. Ela mostrou a segunda casa do assentamento. Eu fui lá, bati palma e ele veio. "Boa tarde, seu Artur". E ele não estava me esperando, para ele foi surpresa. Tomou um susto. "Menina que tu está fazendo aqui?" "Eu vim lhe visitar". "Visitar? Não, tu vai é morar comigo agora". Porque ele já tinha conversado com a minha mãe, sobre isso. Depois eu fui pegar minhas coisas com ele na casa da minha tia Maria.

Sempre tinha reuniões no assentamento e eu participava das reuniões das discussões. No assentamento, me integrei rapidinho. Ia na casa de todo mundo e conversava. Nesse período teve a discussão que ia ter o magistério no estado do Maranhão e cada assentamento teria uma pessoa. No assentamento teve um racha, em volta dessa discussão. Porque não tinha ninguém com a $8^{a}$ série. E tinha que ter a $8^{a}$ série para fazer o magistério que é nível de segundo grau. Dois nomes foram apontados: o meu e o da Silene, uma outra menina que morava lá. Nós fomos para assembléia. Aí teve toda a discussão. Metade 
do assentamento queria que eu fosse e metade não queria, mas a Silene disse logo que não queria fazer o magistério.

Eu até entendi o porquê deles não quererem. Aceitei numa boa. Eu era novata, estava chegando ali e não conhecia como era a organicidade do Movimento Sem Terra, como que era estruturada essa organização. Estava morando lá há um mês. A questão é que era um curso muito bom e era uma responsabilidade muito grande. Porque ia fazer um curso representando todo o assentamento. Se eu fizesse alguma coisa eles iam dizer: "o assentamento mandou uma pessoa que só foi para dar trabalho para gente, uma pessoa irresponsável. Não fez uma boa escolha”. A preocupação deles era essa... Mas como não tinha ninguém, eu comecei. Isso para mim foi muito bom porque eu não estava fazendo nada no assentamento. Passava o dia em casa, sozinha, e meu pai na roça. Para mim foi muito dificil, acho que foi um dos momentos mais difíceis da minha vida. Eu entrei em depressão. Eu digo: "Meu Deus o que é que eu estou fazendo aqui? Eu tenho que ir embora daqui". E eu tinha um dinheiro guardado na minha conta, trezentos reais, que gastei tudo em cartão telefônico. Para ligar para o Rômulo, para minha irmã dizendo que lá era ruim... eu não agüentava mais... Eu não tinha ninguém para conversar! Então queria ir embora dali de qualquer jeito. Um mês depois começou o magistério. Eu fui e minha prima, a Leninha, também foi uma das escolhidas para o curso no assentamento dela, na Água Branca.

Nos arrumamos cedinho e fomos para Vila Diamante. Eu nunca tinha ido na Vila Diamante, que é um dos assentamentos mais velhos da nossa regional Mearinho, onde o conflito para a conquista da terra foi muito grande.

O assentamento, muito bonito, bem organizado e estruturado. Lá é o Centro de Formação Padre Josino. Quando cheguei na porta, vi todo mundo sentado conversando. E tinha muita gente da mesma regional que já se conhecia dos assentamentos. Eu só conhecia a Leninha daquela turma. Foi muito bonito! Cheguei com duas bolsas e todo mundo ajudou, e foram perguntando como era meu nome, de qual 
regional eu era. E aquilo ali foi muito bom. As pessoas são muito acolhedoras. Eu nunca tinha vivido uma uma situação daquela, chegar num ambiente e as pessoas me tratarem da forma que elas me trataram ali. Senti como se tivesse em casa. Eu me achei aqui. Aí eu comecei a conversar com as pessoas e é uma relação muito boa e amigável. Falei da minha vida e as pessoas falaram da delas também. Esse primeiro dia foi um dia de integração. Um dia para todo mundo se conhecer. Teve um momento de todo mundo contar um pouquinho da sua história. No outro dia o pessoal da CPP - Coordenação Político Pedagógica - foi lá e explicou como ia funcionar o curso, a metodologia e o objetivo. No primeiro dia foi mais para organização interna, a nucleação, as divisões de tarefas. Definir como era o dia-a-dia, o que que a gente ia que fazer, os horários, tudo... A importância do curso para o estado, o peso e a responsabilidade que nos tínhamos que carregar. Porque era uma das primeiras turmas de magistério do Maranhão. Era uma experiência nova. Não conhecia o Movimento Sem Terra nesse momento, mas conheci o curso, como era organizado, sua estrutura.

Vendo tudo isso eu me assustei. "Meu Deus como que nós vamos fazer tudo isso? Será se vai dar para fazer?" Nesse primeiro momento tudo foi dado por eles, e teve discussões que nós tínhamos que aprovar. Tínhamos que falar o que a gente queria, se aquilo ali ia dar certo ou não. Aí fiz a relação entre o segundo grau na escola tradicional e aquela escola. Aqui nós temos voz e vez. Nós temos que falar, e lá não; só os professores falavam e a gente tinha que ouvir. E naquele momento foi um choque muito grande para mim. Será que aqui eu vou me achar? Porque até então eu estava perdida. Eu não conhecia tudo aquilo. Foi um choque bom. Porque ali dei meus primeiros passos para a descoberta, para olhar o mundo de uma outra forma. Um mundo libertador, não um mundo opressor como a gente via, tão opressor que até então nem conhecia que ele era assim.

No terceiro dia começaram as aulas. Nós tínhamos que cumprir os horários, acordar cinco horas, ir para o estudo seis horas, até sete horas tomar o café, às sete lavar a louça e fazer as atividades 
práticas... Nos primeiros dias foi bem dificil eu acordar porque quando eu estava no assentamento eu dormia até tarde. Eu conheci a Mazé. Ela faz o magistério junto comigo. Estava com outras pessoas, no quarto, no primeiro dia quando cheguei. Elas me olharam de um jeito desconfiado, mas elas me trataram bem. Foi ruim. Fiquei até triste. Cheguei lá, aí cumprimentei todo mundo, me apresentei elas se apresentaram também. Coloquei as minhas coisas lá e saí. Elas ficaram lá. Depois, com o tempo, elas me falaram, que imaginavam que eu era uma menina rebelde que não ia ficar ali de jeito nenhum. A Mazé conhecia já a luta, como era difícil. E eu não conhecia nada, mas fui me adaptando àquele cronograma e tudo. Fui começando a me achar dentro do curso. Aí a gente concluiu a primeira etapa. Foi mais um momento de integração e de conhecer a diversidade de cultura dentro do próprio estado. A questão do temperamento das pessoas. Foi um momento bem interessante que percebi um pouco de mim, como eu era. Porque a partir do momento que começa a viver no coletivo você se descobre. Eu descobri que eu tinha um medo muito grande de falar. Tinha um momento em que todo mundo tinha que falar. E quando era o meu momento de falar, eu me fechava. Teve até momento em que ficava calada. Eu não sabia desse meu medo. Também descobri de onde vinha esse medo. O que a escola tradicional faz com a gente, como ela nos trata. É uma das formas que o sistema usa, de dominação das pessoas humanas. E dentro da escola você não é tratado como ser humano, você é tratado como aluno, alguém que tem que ouvir, que é um banco de informação. Tem que ouvir os professores falando. Tem que só receber. Eu descobri que tinha que desenvolver, tinha que falar. Foi muito difícil na primeira etapa, não falei nada, até mesmo no momento de eu contar um pouco da minha história quase que a voz não sai, era trêmula. Foi dificil, mas foi muito bom, uma coisa muito emocionante!

O primeiro momento que me emocionei foi na noite cultural, que teve uma mística muito bonita. Muito bonita mesmo! A CPP que fez. Foi sobre a integração, o compartilhar. Nessa mística todo mundo pegava uma fita e colocava no braço do outro. Teve uma falação muito 
bonita sobre o peso da responsabilidade nossa. E naquele momento eu senti o quanto eu era importante! Para o povo do meu assentamento, para as pessoas. O quanto minha responsabilidade era grande. E eu não podia deixar, tinha que carregar o peso dessa cruz. Porque eles precisavam muito de mim. Esse discurso, feito pelo Juca, dirigente estadual do MST, chamava muito a gente para responsabilidade, para o compromisso. E também mostrava um pouco da organização do MST.

Quando terminou a primeira etapa do curso e a gente foi para o momento comunidade, teve uma mística muito bonita. Nesse momento todo mundo chorou, apesar de ser primeira etapa e de todo mundo estar se conhecendo. Foi um momento muito bonito! Todo mundo se despedindo. E, aí todo mundo foi para as suas casas, e eu voltei para o assentamento.

Chegando lá tinha algumas atividades políticas para desenvolver dentro do assentamento, fazer reuniões. Um dos temas das reuniões era a diciplina. Tinham também algumas entrevistas para fazer...O que era mesmo? Eu sei que tinha que conversar com todo mundo sobre determinados temas que eu nem lembro mais. E também fazer reunião discutindo sobre o encontro dos sem-terrinhas. No curso do Magistério, eles explicaram qual a importância do encontro para o Movimento Sem Terra dentro do assentamento. Deram um texto falando sobre o encontro como que eram os critérios de escolha das crianças e das pessoas que tinham que ir para o encontro. Aí eu estudei e convoquei todo mundo para reunião, que foi boa. A gente fez a escolha das crianças e de quem iria. Isso foi uma das primeiras reuniões que fiz. E nessa primeira reunião estava muito nervosa. Ave Maria! Eu estava tremendo. Ficava me perguntando o que eu vou falar. "Será se vai sair alguma coisa?" O pessoal vai me achar insegura porque quando eu falo, fico insegura. Um dos meus problemas é esse. "Mas eu tenho que falar, falar normal". Teve um companheiro que disse assim, "Ana Paula, relaxa, que nós estamos aqui para aprender contigo e você também vai aprender com a gente". Aí ele começou a falar, e naquele momento, bem ali, aquilo me chamou mais ainda para o compromisso. Aí ele fez um 
discurso bem bonito, dizendo que a comunidade me escolheu e que eu não tinha que ter medo de jeito nenhum. A comunidade estava me apoiando, em tudo que eu precisasse eles estavam ali para me ajudar. Se eu tivesse alguma dificuldade é só chamar todo mundo e conversar. Foi muito bom. Naquele momento eu percebi. "É aqui mesmo que eu tenho que ficar. Esse povo precisa de mim".

Daí começa a ter uma relação maior com Movimento Sem Terra. Fui para segunda etapa e foi melhor ainda. Hoje está com três anos, está quase no final do curso!Vai terminar no final do ano. Eu percebo o quanto cada etapa que passa, a cada atividade, a gente vai aumentando o nível de consciência e de certeza de que aqui é o lugar onde tem que estar. Junto com o povo. Nós precisamos uns dos outros para poder superar esse problema, essa desigualdade social. Tudo isso que nos oprime e nos exclui.

Eu já tinha participado de duas etapas do curso de Magistério. Aí chegou o momento que meu pai no assentamento passou por muitas dificuldades. Ele plantou a roça dele, só que era não cercado. Tinha uns assentados que não tinham uma relação boa com meu pai. E gado deles entrou na roça e acabou comendo tudo o que ele já tinha trabalhado. Acabou com tudo. Ele passou uma semana triste por conseqüência disso. A gente sentou e conversou. Ele disse que tinha tomado uma decisão: não iria ficar mais no assentamento. Nosso assentamento também estava passando por um momento muito dificil, estava desorganizado. Eu pedi muito para ele não ir. Ele participou de todo o processo de ocupação desde o início e nós já estávamos naquele estágio e não era para ele desistir. Eu estimulei muito, mas ele resolveu que não iria ficar. Então, ele perguntou se eu iria com ele e eu falei que não. Eu fiz uma opção na minha vida: resolvi ficar. Depois disso, não tivemos uma relação boa como antes. Ele foi embora, morar com a minha mãe que estava sozinha lá no nosso povoado. E eu fiquei no assentamento. Passei uns três meses morando sozinha. Eu comia na casa dos assentados porque eu não tinha dinheiro para comprar tudo que precisava. Mas sempre minha mãe ajudou, mandava dinheiro para 
me alimentar. Eu ia em casa e ela comprava o básico que eu precisava. O tempo foi passando e eu fui me adaptando, apesar das dificuldades serem muito grandes. Tinha dia que eu pensava na decisão que eu tinha tomado. "Meu Deus, será se eu vou agüentar ficar só?" Porque antes eu morava em Bacabau, tinha minhas amizades.

Foi um momento muito difícil de mais! Imaginava que eu não iria suportar. A tristeza, a solidão de não ter alguém para conversar como antes. As pessoas que ali estavam eram pessoas que não conhecia muito. Tinha uma relação de conversa sobre os problemas da comunidade, que tentava resolver. Mas para uma conversa mais pessoal, não tinha ninguém. E isso foi muito difícil para mim. Mas o tempo passou, acabei me adaptando a tudo aquilo, superando esses problemas. Muitas pessoas durante esse tempo me ajudaram, o Juca, o Noé, a Mazé. Nas etapas do Magistério, a gente conversava muito. Foram pessoas que me deram muita força. Durante esse tempo tirei como lição o quanto a família da gente é importante. Antes via a família como uma coisa natural. Nunca tinha passado por momento igual aqueles. Comecei a dar valor para as pequenas conversas, o simples gesto, que para gente, nesse momento, vale tudo. Hoje, a gente se aproximou mais, eu e meu pai. Ele percebeu a importância de eu ter ficado. A gente conversa muito sobre a organização do nosso povoado. Como que a gente vai fazer para organizar porque lá não tem a organização como tem no MST. Quando chego a gente faz reuniões com a associação. A gente está trabalhando, chamando a comunidade, mostrando qual a importância de se organizar para reivindicar os nossos direitos. E as pessoas lá no povoado me respeitam. Fico muito feliz com isso.

Hoje, eu sou muito feliz por ter tomado a decisão de ficar no assentamento, porque foi uma opção. Eu mudei de mundo! Tudo é muito diferente.

Meu pai perdeu o direito à terra a partir do momento que ele saiu do assentamento. Então, eu não sou assentada. Eu só milito no Movimento. E meu pai hoje ainda está morando lá na Bomba com 
minha mãe. Meus irmãos estão em Bacabau, estudando, passaram no vestibular. Minha mãe faz Filosofia e meus dois irmãos fazem Pedagogia.

Uma das coisas bem interessantes é meu irmão. Ele tem uma concepção muito boa. Ele era da PJ - Pastoral da Juventude. Ele diz que ainda vai trancar o curso, para morar comigo porque ele acha muito interessante, muito bonito. Sempre que eu vou para casa a gente conversa muito. Ele questiona muito. E a gente vai aprendendo um com o outro porque ele tem uma formação muito boa. Uma das pessoas com quem gosto de conversar a questão política é ele, meu irmão Paulo.

No curso do magistério tem leituras tão boas ou melhores do que no curso de Pedagogia que meu irmão faz. Sempre que vou para casa ele pega o meu material do Magistério e fica olhando. A primeira coisa que ele pega é a minha pasta de livro. "Ana Paula tu tem livro diferente? Deixa eu ver. Trouxe algum livro de presente para mim?” A gente conversa muito sobre os conteúdos do curso e a gente foi descobrindo que tem muita coisa a ver. O que a gente está vendo no Magistério, às vezes, é a mesma apostila que ele está vendo no curso dele.

Eu adorei ficar no curso pela questão do relacionamento. Sente como ser humano, se sente importante!

A identidade sem terra é muito forte porque não é pelo fato de plantar, de ser uma camponesa, de trabalhar na terra, mas sim pelo fato de você levar essa identidade com você. Essa identidade é muito forte, ela vai além disso. A gente sente essa identidade quando leva os sentidos da organização, como o compromisso. Um dos princípios é a organicidade. Quando você vê a organização no todo, se sente como sem terra. Essa coisa da organização interna da nucleação, da estruturação...

$\mathrm{Eu}$ acho que o compromisso mais importante é com a luta mesmo. A luta de classe. Estar ali lutando pelos seus direitos, acho que é uma das coisas mais importantes. 
A discussão no estado é que as pessoas que estão fazendo magistério não iriam para marcha. Porque a etapa do magistério vai começar dia 16 e ia atrasar. Na preparação da delegação para vir para marcha a gente trabalhou muito. A gente dividiu a brigada de organicidade em dois grupos. No meu grupo, éramos cinco pessoas e ficamos com os assentamentos mais longe, geograficamente, de mais dificil acesso. Nós tínhamos que fazer essa discussão em uma semana. Nós fomos para lá e fizemos em todos os assentamentos. Lembro que tinha que atravessar um lago enorme de canoa. A gente passou muita dificuldade para fazer essa discussão da marcha. Mas a gente fez. Foi um mutirão. Discutimos a questão da arrecadação de alimento, dos critérios, o que era e qual o objetivo da marcha... Como estou na frente de massa, fiquei mais o Noé na articulação do ônibus, para conseguir o dinheiro na nossa regional. Não tinha recursos para pagar o ônibus. Já estava em cima da hora, o Noé tinha que vir para Brasília conseguir recursos para marcha junto com a equipe nacional. Às vezes nós íamos para a prefeitura da cidade próxima, ficava até meio dia sem comer nada, na porta, esperando o prefeito nos receber. Mas a gente conseguiu. Quando o Noé veio, fiquei só, trabalhando. A responsabilidade é muito grande, a minha regional só viria se eu conseguisse sete mil reais para pagar o ônibus. Nessa articulação a gente conseguiu cinco mil reais. O restante, conversei com o Jonas, e o Movimento Sem Terra do Maranhão iria pagar. Daí tudo bem, conseguimos.

Mas tinha certeza que eu não vinha. Tinha chorado tanto! Ficava imaginando: "dez mil pessoas marchando, deve ser uma coisa muito bonita!" Chegou o dia que esperávamos toda a delegação. Íamos fazer um estudo antes da delegação partir. Eu mais o Juca ficamos responsáveis para fazer isso. Foi muito bonito a forma que o Juca falou, chamando o pessoal para o compromisso, a responsabilidade que nós tínhamos, todo mundo ia representando o assentamento. E nessa hora eu comecei a chorar. Aí eles: "calma Ana Paula, que na próxima marcha tu vai. Vai ser vinte mil, então tu vai". Nós tínhamos nesse dia que 
esperar o ônibus que vinha de São Luiz, da outra regional que estava atrasado. Quando o Jonas, dirigente estadual, chegou, disse: "cuida, cuida. Se arruma que tu vai”. A discussão que foi feita na direção estadual decidiu que eu e a Mazé, como éramos da frente de massa, tínhamos que vir acompanhando o pessoal. Fiquei tão feliz que comecei a pular, gritar. Não sabia se chorava ou se sorria. Eu disse: "Não acredito que eu vou". Eu abraçava e beijava todo mundo. Eu corri, arrumei minhas coisas, botei umas três mudas de roupa na bolsa. Eu não sabia que tinha que trazer roupa de frio, eles falaram que aqui estava muito quente. Saí toda suja, nem tomei banho. Entrei no ônibus e a gente veio. $\mathrm{E}$ foi muito bom mesmo! Vieram quatro ônibus do Maranhão. Toda parada a gente se encontrava e começava a conversar. O Jonas, vendo a minha alegria, falava sorrindo: "taí, menina, tu veio!" No primeiro dia, conversando sobre a articulação, o Jonas perguntou: "o que tu está achando da marcha?" Eu disse: "meu irmão, tu é doido. Isso é uma coisa maravilhosa!" Sente assim... como se... não sei nem explicar o que estou sentindo. A gente fica encantado com o Movimento, a força de organicidade que tem para colocar mais de dez mil pessoas aqui, saber quem é quem, ter todo o controle. Além disso, sentir a força de articulação do Movimento Sem Terra e o nível de consciência que as pessoas têm. É muito bom ver a alegria de todo mundo, conhecer pessoas de outro estado, ver a diversidade cultural, o sotaque. Alguém passa e a gente fica rindo do sotaque do outro. Todo mundo sente aquela harmonia como se fosse uma família.

Eu adorei participar da marcha. Se eu tivesse perdido, não ia perdoar ninguém. Quando o pessoal que veio, voltasse para os estados, iam falar sobre a marcha. E eu também iria acompanhar pela televisão apesar de ser uma coisa distorcida, mas pelo fato da gente conhecer, sente como que é a coisa.

Gostei de todos os momentos da marcha. Mas um momento que marcou mesmo foi aquele tumulto, aquela confusão de ontem na Esplanada dos Ministérios. Porque a gente sabe que estava fazendo uma manifestação passiva. E como que os caras reagiram. Isso foi já 
uma coisa planejada, pensada, dá para perceber a provocação que eles fizeram. A gente percebe o quanto eles estão articulados, o quanto nós temos que nos organizar para que não cair nessas provocações e o quanto a gente falhou.

Isso marcou de forma negativa pelo fato de toda a trajetória da marcha, fizemos tudo certinho. Apesar de toda aquela coisa bonita que a mídia mostrou, no final fechar com isso a imagem do Movimento. E isso é muito ruim para nós.

Não teve ninguém do nosso estado que ficou machucado. Eu não estava muito perto, mas deu para ver a violência dos policiais, como que eles agem.

Quando a gente ia marchando tinha uns policiais que perguntavam de onde a gente era, porque que a gente estava ali. Sorria, fazia um gesto... Apesar deles serem mandados, a gente percebia que muitos deles ali são a favor do MST. A gente percebe o que o sistema faz com as pessoas. Chega um momento que não olha para um companheiro, ou para outra pessoa como um ser humano. E isso é muito decepcionante.

Tudo tem seu lado bom e o seu lado ruim. No Movimento mesmo temos várias dificuldades, a questão financeira, a questão da alimentação que não chega no horário, essa questão da estrutura. A gente, não, nós temos dificuldades. Mas eu acho que essa força e essa vontade superam as dificuldades que nós temos. Tudo isso não chega aos pés do objetivo que nós estamos tendo e que está sendo realizado.

A luta é complicada. É até difícil a gente falar sobre isso. Tem o seu lado ruim. Seria tão bom se todo mundo tivesse o seu pedaço de terra e não estar desse jeito. Se todo mundo tivesse onde trabalhar e o que comer. Se tivesse mais justiça. Não precisaria ter sem terra.

Às vezes queria que algumas coisas fossem diferentes. Por exemplo, na parte financeira. Estou atuando na regional, só que eu não ganho ajuda de custo de jeito nenhum e minha mãe que me ajuda. Tem momentos que a gente quer sair ou comprar alguma coisa e não tem dinheiro. A gente imagina se tivesse condições... Porque a gente vê as 
situações de outras pessoas que estão melhores do que a gente. A questão financeira é muito forte, pesa muito. Eu não queria deixar de ser sem terra porque tem muita gente que tem dinheiro mas não vê o outro como ser humano, vê como um objeto. E nessa parte, bem aí, que eu não quero nunca deixar de ser sem terra, de perder essa minha identidade. Porque você valoriza a questão humana. A questão cultural. Respeita o outro. Essa identidade é muito bonita por tudo isso!

Não consigo mais estar fora do Movimento. O que eu me identifico mais é quando eu estou fazendo o trabalho de base mesmo. A gente está na comunidade, trabalhando, discutindo os problemas. A gente vê a importância que as pessoas dão para gente e isso é muito valoroso. A gente fica até emocionada quando chega nos assentamentos. A gente termina de almoçar numa casa, as pessoas insistem "Come lá em casa!" ou "tu tem que comer, nem que seja um pouquinho lá em casa”. A gente se sente feliz com isso. A importância que as pessoas dão para gente. É muito difícil ter isso fora do Movimento.

Estou no setor da frente de massa, um dos setores que eu mais me identifiquei. Eu já participei do setor de formação, de educação. Como eu fazia Magistério eu acompanhava as escolas na nossa regional, com o Juca e outros companheiros. Depois a gente discutiu que a nossa regional estava com muito problema em relação ao setor da frente de massa. Aí eu comecei a acompanhar, e hoje acho que é nele que eu vou ficar. Porque trabalha com o povo. Ali a gente sente o cheiro do povo. Como é gostoso!

Por outro lado, não sei, mas no Movimento, o que eu percebo que eu não gosto de jeito nenhum é a disputa de poder. Tem muito isso. Acho isso feio. Eu acho que se todo mundo está ali é porque já tem aquela formação adquirida. Então, acho que todo mundo sabe porque que está ali e reconhece que somos iguais. Nós temos os mesmos direitos. Acho que as pessoas não poderiam ver e agir dessa forma. Às vezes mesmo no trabalho da frente de massa a gente percebe isso. 
Sempre tem aquelas pessoas que querem falar, não dão espaço para as outras. E a gente percebe isso. Porque a partir do momento todo mundo está falando, estamos nos formando e formando novas consciências.

Eu queria dizer assim: hoje eu vejo o mundo muito diferente do que eu via antes. O Magistério para mim foi uma abertura no meu modo de ver as coisas. Porque eu acho que se não fosse a minha ida para o Magistério, eu não sei o que seria de mim hoje. Eu não tinha essa visão que tenho de se libertar dessas correntes que está nos machucando ideologicamente e que não vemos. Estamos sendo maltratados, oprimidos, excluídos dessa sociedade. O Movimento Sem Terra está resgatando valores. Para viver melhor, para olhar e ver o outro. É nesses valores que, cada dia, a gente tem que se apegar mais porque assim que nós vamos construíndo nossa casa. Já temos um alicerce bem grande que cada dia está aumentando mais. O nosso objetivo maior é a reforma agrária, que é bem ampla, como todo mundo já sabe.

Estou feliz de ter contado minha história. Foi muito bom ter participado dessa pesquisa. Falar dos outros, é fácil. Mas a partir do momento que vai falar da sua história fica pensando, relembra tudo o que aconteceu e isso é um exercício muito bom. Voltando ao passado, reflete algumas coisas que futuramente vai melhorar. Faz essa reflexão da sua vida toda, isso é muito bom. Gostei muito mesmo de dar a entrevista.

Eu queria dizer que o Movimento Sem Terra cria vários momentos de formação. Uma entrevista dessas é um momento de formação. Dá para perceber a história do nosso povo. A história de cada um e cada uma não é diferente, está envolvido numa coisa só, muito bonita, a nossa organização. A luta de todos é igual, um só objetivo. 


\section{Aquiles}

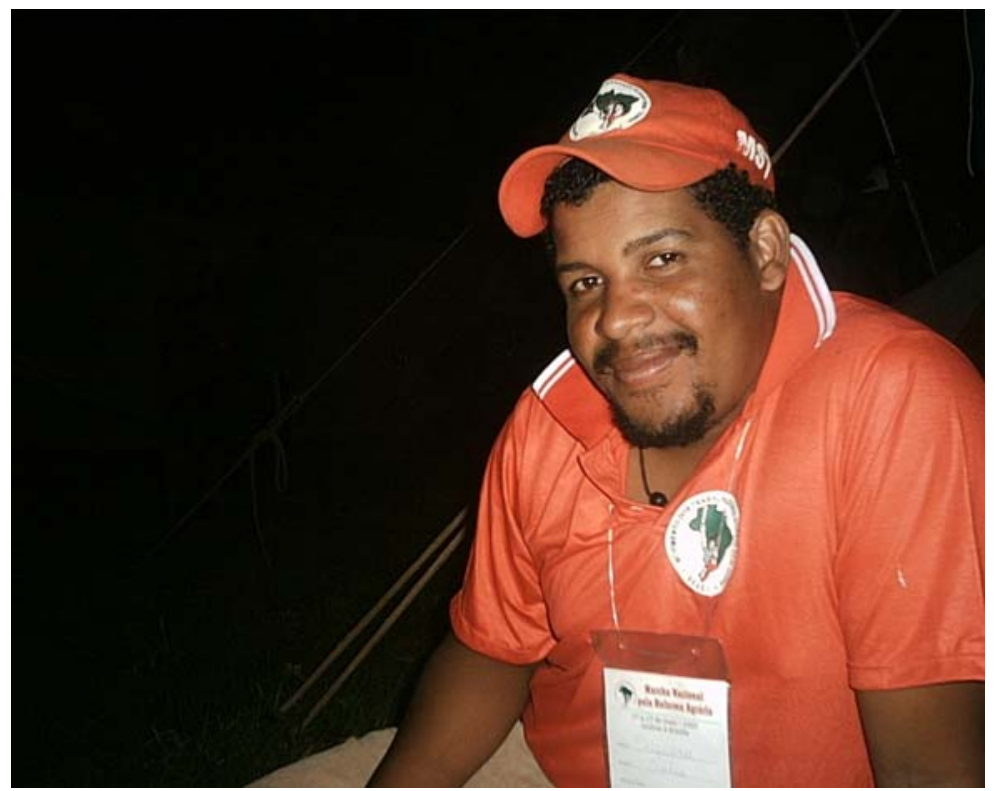

Sica, como era conhecido, é um jovem convicto e muito bem humorado. A única coisa que o fazia por vezes perder a fala era a tosse, sintoma da gripe que estava por todo o acampamento. Liderança, sentiu na pele os efeitos e a força da luta coletiva. Antes mesmo de começarmos a gravar a entrevista, enquanto estava explicando o projeto, disse: "não sou nada sem o Movimento". Essa afirmação foi seu ponto de partida. E ecoou na minha cabeça durante todo o tempo da pesquisa até esse ponto de "chegada".

Entrevista gravada em 15 de maio de 2005. 
Eu não tive vida fora do Movimento.

Você me pergunta sobre minha vida antes de entrar no MST... Eu não tive vida fora do Movimento. Tudo que sou é graças ao Movimento. Aprendi tudo aqui. Antes... não tem como contar! Entrei com sete anos no MST. Tudo que fiz... Todos meus estudos... Não fiz nada fora do MST.

Essa história da marcha nasceu também, no Movimento Sem Terra, na luta, a mobilização nacional no Estado.

Às vezes, quando a gente participa de uma caminhada dessa, as pessoas acham estranho. Na marcha de 1997, eu tinha 22 anos. Lembro que muita gente colocava assim: "Vocês são jovens! Participar de umas caminhadas dessas é muito ruim. Por que não procuram um caminho pra vocês?" Mas, para alguém que falava isso, era fácil, porque às vezes tinha um pai que era fazendeiro, ou então empresário. Para quem sabe que tem que procurar o futuro, que o pai já nasceu na exclusão desse país, é diferente. Então, a gente vive a história nossa. E não é uma história triste. Muita gente acha: “Ah, isso é triste. Como é que passa o tempo todo caminhando?... o tempo todo fazendo ocupação?..." Para nós não foi triste, foi alegria. É um negócio que acho que nasce plantado dentro da gente e que não quer abandonar. Hoje, se o povo perguntar: "Quer uma vida fora do Movimento Sem-Terra?” Vou responder assim: "Que vida fora do Movimento Sem Terra? Essa foi a vida que nós construímos!" Quando constrói, não pode abandonar o que construiu.

Iniciei os estudos de alfabetização dentro do assentamento, com idade de 11 anos. Tenho uma alegria muito grande de nunca ter estudado fora de assentamento. Até o magistério, que terminei o ano passado! E tem mais outra alegria: essa escola foi nós mesmos que construímos... lutamos, corremos atrás. Foi uma luta importante da 
marcha de 1997, que era por reforma agrária, mas que a gente pedia que o Governo Federal investisse na educação dos assentamentos. E conseguimos!

Em 1999, a gente participou de outra manifestação que foi a marcha popular pelo Brasil. Naquela marcha, uma das questões que a gente desacreditava, e ainda desacredita, era o presidencialismo, ou seja, a questão de um presidente ganhar a eleição, governar país e fazer alguma coisa. Hoje a gente sabe que ninguém faz nada. Presidente da República não é nada, diante do que a gente precisa e necessita. Sobre a reforma agrária, por exemplo: o Lula pode querer assentar 10, 20, 30 mil sem terra, mas tem o limite que a justiça coloca... A gente participou de uma reunião, nessa marcha, com o presidente nacional do Incra. Fui participar desacreditado, porque o que ele falou hoje foi o mesmo de 2003. E o avanço que teve em 2003 é o mesmo que tivemos em 2004, e já estamos em 2005... É muita conversa... E nada. A justiça impede que a reforma agrária seja feita, a justiça impede que o pobre, consiga alcançar...

Não consigo nem falar direito de tanta tosse...

Então, a justiça impede que a gente conquiste o sonho nosso. Mas, nem por isso a gente vai baixar a cabeça, parar. Fizemos a marcha de 1997, com aquele número de famílias que era muito importante. Em 1999, fizemos a marcha com mil pessoas: 70\% era jovem! $\mathrm{E}$ a gente falou assim: "Meu Deus, será que um dia vai conseguir fazer a marcha com 10 mil?" E conseguimos! Nessa, agora fica pensando: “Será que algum dia vai fazer uma marcha com 50 mil?”

É uma pergunta que a gente não faz para ninguém, faz para nós mesmos, e já sabe que consegue fazer. No dia que falar vamos botar 100 mil pessoas do Movimento Sem Terra dentro de Brasília, vamos fazer!

Então, essa é uma luta que a juventude tem que abraçar. A gente vê que $50 \%$ dessa marcha é jovem. Aí o povo fala: "Por que vocês não vão pra escola?!” Temos as nossas escolas. Escolas que permitem 
vir aqui e quando voltar vão estar lá esperando nós para estudar. Como é que foi que conquistamos essa escola? Conseguimos nessa luta. Fazendo ocupação, pedindo ao Governo Federal que faça investimento na educação do jovem do campo!

A marcha de Juiz de Fora deixou um exemplo grande para nós, de humildade, de luta, de estar junto um com o outro. Às vezes, se sumia um colchão da marcha, dormia três em dois colchões... Cada dia que passa, vai sendo humilde um com o outro. Então, quando fala assim: "Vamos pra marcha!", cada um desses 10 mil, tem a tarefa de trazer mais 10 . Se tem a tarefa de trazer mais 10 , não impede daqui a três anos fazer uma marcha com 100 mil. Entendeu? Fazer a marcha com 100 mil é a coisa mais fácil que tem! A gente sabe que tem que conquistar apoio, mas tem governador que ajuda. Acha importante a marcha para os estados, porque a gente está correndo atrás de questão de investimento para o Estado também.

A justiça tenta impedir como aconteceu agora com um governo de Goiás. Criou uma polêmica grande, com o prefeito de Goiânia... Mas, a gente sabe que mais de 500 prefeituras e mais de cinco governadores nesse país contribuíram com essa marcha. E vão continuar contribuindo, de uma forma ou de outra. A gente fica bastante satisfeito de ver o empenho de alguns governantes desse país, que acreditam no Movimento Sem Terra. Que acreditam que a gente está pronto e preparado para ajudar a fazer a mudança desse país. Isso, para nós é importante. Essa marcha está deixando claro que o que a gente quer o Governo Federal não consegue. Então, tem que fazer mobilização na porta, do Ministério da Justiça, da Educação, de Reforma Agrária, todos os Ministérios... Antes só vinha para o Ministério da Reforma Agrária. A gente achava que era nosso lugar, porque a reforma agrária tinha que ser feita lá. Hoje é diferente, tem que ir em todos os Ministérios.

Às vezes, a gente tem muitos presos políticos. Que vai preso pela versão da justiça... não tem a versão do trabalhador. "O Movimento 
Sem Terra é formador de quadrilha... Está preso!" Aí bota isso na mídia, e muita gente pensa que é verdade. Pensa que assistir a mídia é saber da verdade. Mas não é porque queremos a reforma agrária que somos formador de quadrilha. Somos pessoas que formamos grupo de opinião para mudança desse país, como a reforma agrária, a educação e outras questões. Hoje, não lutamos só pela reforma agrária, lutamos por mudança social. Lutamos para que a cidade seja feliz com a forma de ser governada e que o povo do campo seja feliz também. Então, só a marcha, só o povo em fileira, com um pensamento, para conseguir alcançar o objetivo que queremos.

Mas, voltando para trás. Como disse, entrei no Movimento com sete anos. Foi assim... Em 1982, um senhor era gerente de uma fazenda e chamou meu pai e meu tio para ser meeiro. Só que tinha um negócio estranho. Porque a fazenda era tudo capoeira. Aí, conforme os trabalhadores iam fazendo as roças, colhia e, naquele lugar, no outro ano, não podia plantar mais, porque eles vinham atrás plantando capim. Ia desmatando... e ele plantando capim... Estranhamos e falamos: "daqui a algum dia você não vai querer que plante mais, porque está plantando capim..." Foi dito certo!...

Mas, já tinha 120 famílias organizadas, que foi discutir com ele. Aí, ele pediu para todo mundo afastar da fazenda que ia criar boi. Trouxe mais de 1500 bois, jogou dentro, das roças do povo, e estragou tudo que tinha. Foi aí que fomos para o sindicato, município de Itamaraju, no sul da Bahia, e organizamos uma mobilização. Em 1985, saiu o decreto de desapropriação da área, onde minha mãe é assentada hoje.

Completou 21 anos de assentamento. Nesses anos, o processo da gente foi esse, junto com os pais nossos. Antes, a gente cuidava... com 11 anos a gente pegava em espingarda para enfrentar os pistoleiros do fazendeiro. A polícia federal também ia lá e abusava bastante de nossos pais, na questão de pegar o animal que a gente tinha. Mandava matar: jegue, cachorro, tudo. Mandava derrubar as casas nossas. 
Pistoleiro junto com a polícia. Os pistoleiros derrubando e a polícia dando suporte. A polícia federal e a militar. Aquilo era um desgosto!... A gente achava que ia crescer com aquele desgosto na cabeça, de ódio. $\mathrm{E}$ ai de acordo com processo da reforma agrária, viu que a mudança veio. E iniciou o Movimento Sem Terra, em 1987. Já tinha uma base no assentamento nosso que era feito pelo sindicato. Era para ter assentado as 120 famílias, mas só deu para assentar 44. Então, iniciou o Movimento Sem Terra pegando o restante das famílias e assentando em outros assentamentos como o Guaíra.

Depois disso, o movimento cresceu. Formamos mais de 11 assentamentos no Sul da Bahia, e expandindo em todo estado. Hoje, sou dirigente do Movimento Sem Terra, sou da direção estadual e dirigente da região Oeste. Na região Oeste hoje tem 11 assentamentos e cinco acanpamentos, envolvendo 1800 famílias. Às vezes, quando estou lá, paro para pensar: quem eu era em 1985? Quem sou hoje? Quem me deu aquilo? Como é que foi? Tudo o que a gente tem foi conquistado. Através de uma bandeira vermelha. Uma bandeira importante: a do Movimento Sem Terra. A gente tem um amor muito grande por ela e a cada dia que passa, quer ir construindo e fazer com que ela cresça, expanda por aí a fora.

Hoje, me sinto muito alegre de ser acreditado dentro da organização. Tenho 13 anos na direção do Movimento Sem Terra. Com 15 anos assumi a função, e nunca vim trazer desgosto para organização.

Tenho 22 irmãos. Filhos do meu pai!... Filho de minha mãe, que foi o último casamento, só 12 . Desses 22 irmãos, só eu faço parte da organização do MST. Tem mais uns que estão no assentamento, produzindo. Cada um tem seu pensamento, mas penso que se ficar no assentamento não vou ter nunca como pagar o Movimento Sem Terra por aquilo que fez pela minha família. Porque hoje são assentados, duas tias, dois tios e mais três irmãos. Então, alguém tem que fazer alguma coisa no Movimento Sem Terra para pagar, e fiquei com essa tarefa na 
organização, de estar correndo atrás, de outra família, fazendo com que cresça.

Hoje estou um pouco triste porque tem nove meses que não vejo a mãe, na Bahia. Às vezes ligo para ela, mas quando não consigo falar, fico meio preocupado. Dentro do Movimento Sem Terra a vida é essa. A gente vai tocando porque dentro do MST tem outras mães que a gente vai construindo no dia-a-dia, nos acampamentos, nos assentamentos novos. E essas mães nos acalentam enquanto está distante da mãe da gente. Mais nunca apaga aquela memória de dentro da gente. Qualquer tempo que tiver, tenho que escapulir para ver ela, porque se não fosse ela, não estava hoje na organização.

O Movimento Sem Terra, na Bahia, é uma família coletiva! Mas que não apaga um pouco o amor que tem pela mãe da gente de verdade. Ela mora num assentamento que fica no município de Prado, 55 quilômetros da cidade, 12 quilômetros de Itamarajú. Lá, tenho oito irmãos, cinco homens, três mulheres, e outros companheiros. Trabalhei no assentamento cinco anos. Também fui responsável pela fábrica de cachaça que a gente tinha. Depois vi que não dava para ficar ali direto, me sentia preso. Aí começamos a botar o pé na estrada e caímos fora. Saí do extremo sul, em 2001, e fui para o Recôncavo para algumas ações do Movimento Sem Terra. Depois desci para o Oeste e assumi a coordenação lá, onde estou até hoje! Um dia, se houver discussão no Movimento Sem Terra na questão do rodízio de dirigente posso mudar, estou preparado para fazer o possivel pela organização.

É por isso que posso dizer que me sinto do Movimento Sem Terra. Ser Sem Terra hoje é importante para nós. Porque muita gente coloca assim: "Sua mãe é assentada. Você, se quisesse ser assentado, já era assentado. Por que que você continua sendo Sem Terra?” É uma matéria nossa. Somos todos filhos da terra. Mas será que todos filhos da terra têm a terra? Não têm. Então já que tantos irmãos nossos não têm terra, a gente prefere continuar sendo Sem Terra... Quem sabe um dia a gente não vai ser Com Terra? Mas até hoje a gente prefere ser sem 
terra porque tem mais de dois milhões de trabalhadores sem terra do campo no Brasil. Então, enquanto houver família na cidade que era do campo, que prefere o campo e está na cidade, continuamos sendo Sem Terra.

Carregar esse emblema no peito, vestir essa camisa vermelha para mim é a minha maior alegria. Um dia, estava no Oeste, e a TV Oeste, um canal da Bahia, me chamou para dar entrevista, falar sobre que avanço tivemos no governo Lula, como é que o Movimento Sem Terra estava vendo o primeiro ano de governo. Fiquei um pouco sentido porque não tinha camisa, aí pedi para adiar a entrevista para três dias depois. Vim ver em Salvador se tinha uma camisa para mim. Aí, quando eu falei com o jornalista que eu não tinha camisa, que eu não ia por causa disso, ele disse: "que nada, bota um boné!" Mas esperei os três dias e a camisa chegou! Muita gente coloca que é uma doença. Não é! É questão de adotar o Movimento Sem Terra. Se vou falar da nossa organização, tem que estar vestindo a camisa, vestindo o nosso símbolo.

Essa sigla está plantada na gente por mais que não esteja por fora, no nosso corpo, já está por dentro da gente. Muita gente chega na rua e conhece a gente sem precisar estar com a camisa e com o boné. Acho que a presença do Movimento Sem Terra está no rosto, na memória, no nosso falar. Quando chega numa escola e coloca algum assunto, o povo já toca, "esse povo é do MST. É do Movimento Sem Terra”. Há uns dois meses, no início das aulas, fui para o Colégio Modelo, dar uma entrevista. Quando coloquei que a gente discordava da posição do Governo Federal, com a questão da reforma agrária, questão de sindicatos isso e aquilo, a maioria falou: "Esse menino é do MST". Eu nem tinha falado. Então a presença desse "nós" está no nosso corpo, nosso rosto, nosso cabelo, o nosso andar, nosso dormir, no nosso jeito de se expressar...

Amém!? Ficou engraçado do jeito que disse tudo isso!!...

Mas, continuando, a respeito dessa marcha... cabe uma questão... Às vezes, a gente está aqui, porque tinha um costume de ter 
andado do Rio de Janeiro à Brasília... Porque participou da marcha de maior distância que já teve do Movimento Sem Terra. Foram 72 dias, caminhando direto, e a gente cria aqui na memória da gente. É tipo jogo de futebol. Quando bota na memória que todo dia de manhã tem que jogar bola, então todo dia de manhã tem que fazer isso! Na marcha do Movimento Sem Terra, viemos para caminhar...

$$
\text { Mas quando a gente }
$$
chega aqui, às vezes tem outras funções. Para a marcha dar certo, tem que ter 10 pessoas responsáveis pelas bolsas dos estados, 10 pessoas de cada mil para cozinhar para aqueles que estão caminhando e ainda 10 pessoas para fazer as barracas.

Essa tosse não para!
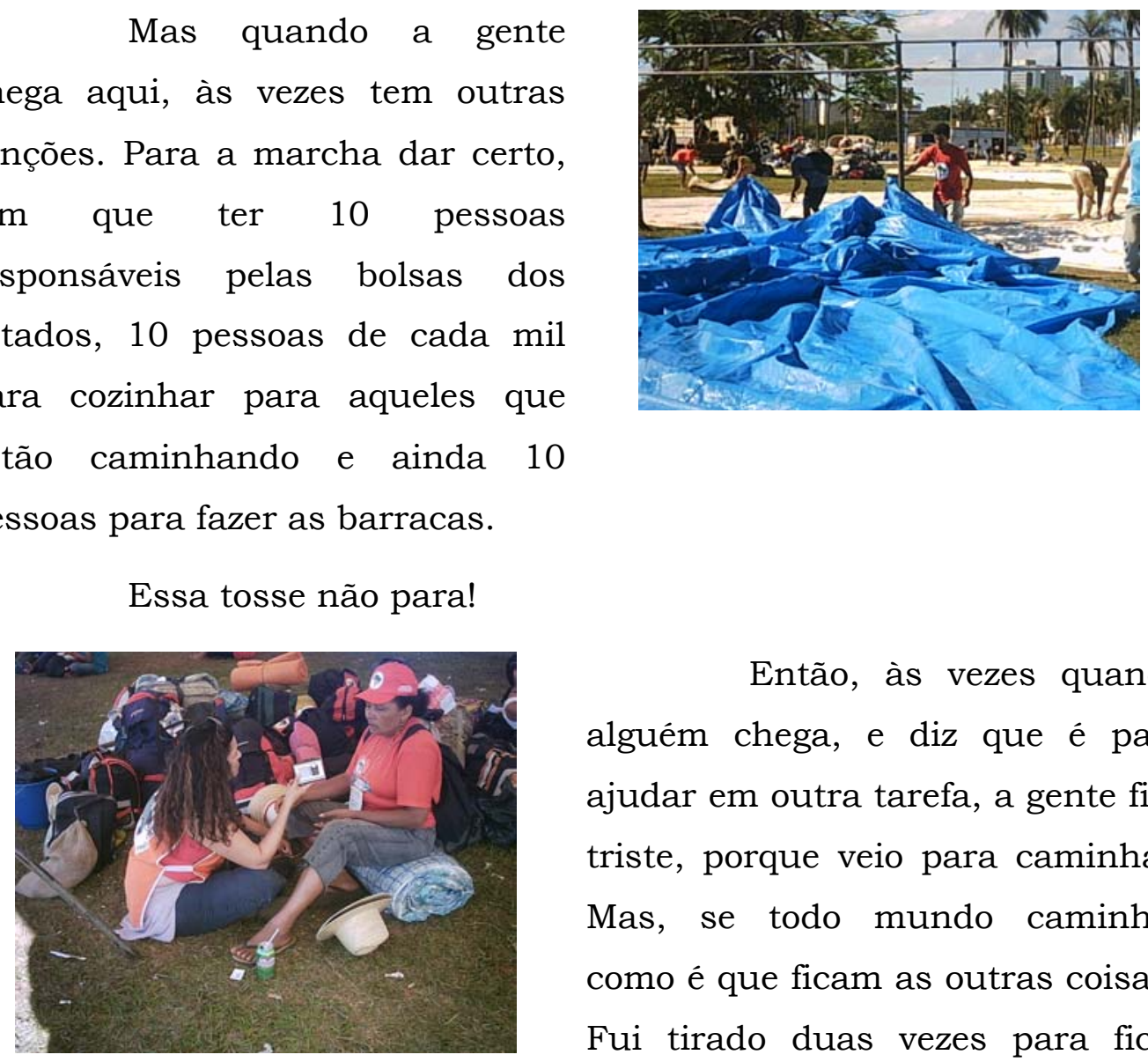
Então, às vezes quando alguém chega, e diz que é para ajudar em outra tarefa, a gente fica triste, porque veio para caminhar. Mas, se todo mundo caminhar como é que ficam as outras coisas? Fui tirado duas vezes para ficar responsável pelas bolsas... Eu não quis, discuti e botaram outro no lugar. Estamos caminhando. Estamos firmes porque é uma tarefa nossa.

Às vezes, tem pessoas que não se sentem bem na marcha. Algum tipo de gripe, febre... por isso tem que ficar parado, de repouso. Aí fica responsável pelas bolsas. E a gente pica o pau caminhando. Estamos firmes caminhando. Não está doendo o pé nem a cabeça! Deu 
uma gripe muito forte que está pegando todo mundo, mais gripe não é doença!

Fico mais orgulhoso quando a gente levanta 5 horas da manhã e vê 10 mil pessoas na estrada caminhando. Aí estou satisfeito! Porque se tiver menos, não é a mesma coisa. Para nós é um orgulho grande completar os 10 mil.

Sinto orgulho de muitas coisas no Movimento Sem Terra: de ser jovem e de estar aqui e das mulheres do Movimento também. Quando a gente fazia uma mobilização do Movimento Sem Terra com 100 pessoas, ia 10 mulheres e 90 homens. Hoje é diferente. Olhando a lista tem quase quatro mil mulheres aqui. É uma alegria muito grande. Qual era a função da mulher no início do Movimento Sem-Terra? A gente achava que a mulher tinha de ir para mobilização para cozinhar. A mulher tinha de ir para tomar conta da bolsa do marido. Hoje é diferente. A mulher tem a mesma função que nós temos. Essa questão de gênero a gente está tomando pesadamente, que o homem tem que ir para cozinha. Ou seja, se tiver 100 pessoas para cozinhar para esses dez mil, 50 tem que ser homem e 50 mulher. Isso vem trabalhando e cada dia a gente vai vendo a mudança. Ainda não tem 50\% das mulheres na marcha, mas a gente torce para que um dia tenha. Não só na marcha, como também nos assentamentos, na mobilização, na direção do Movimento Sem Terra. Em tudo quanto é função que tiver. Então tenho um orgulho muito grande de ver isso! De ver as mudanças que teve na organização e uma delas foi essa da participação das mulheres.

A gente participou de muita coisa no Movimento Sem Terra, essas três marchas nacionais foram uma questão de grande importância histórica... de algumas ocupações do Incra, da CDA, Coordenação de Desenvolvimento Agrário, que é um órgão do governo do Estado da Bahia... de outras ocupações em outros estados como Paraíba, Sergipe, Pernambuco... Então, para nós é importante isso! 
Sente orgulho de estar sempre firme. Mesmo com as perseguições: da televisão, da polícia, de alguns governos...

Eu tinha um pensamento, de criar uma correlação de forças dentro do Movimento Sem Terra... um grupo de 10 mil jovens de todo o Brasil para estar quebrando algumas correntes traçadas para organização. Cada estado poderia formar 500 jovens para o que der e vier, dentro da organização. Tipo agora, tem uma deficiência grande em Alagoas, um companheiro nosso foi preso... Não pode concordar com aquilo. Acho que se um companheiro nosso vai esperar julgamento da justiça, tem que ser fora da cadeia, fazendo a reforma agrária. Tinha que ir lá e mobilizar para tirar nossos companheiros! Outra coisa, hoje o Governo Federal tem uma dificuldade grande porque dentro do Incra tem a procuradoria. Se ela disser que naquela área não sai reforma agrária, não sai mesmo. E o Governo Federal não tem como bater, porque só a procuradoria diz o que sai. Então, existe isso. Tem que quebrar isso! Deputado estadual, federal, senador, governador... não vão quebrar nunca. Ou jovem organizado quebra ou então adeus! Acho que isso é importante o Movimento Sem Terra estudar bastante e ajudar para que a gente faça essa discussão.

A gente tinha um encontro importante, de jovens do campo e da cidade. Acontecia na Unicamp. Todo ano! Mas parou. É importante um encontro nacional da juventude do Movimento Sem Terra Ela tem muita coisa para botar em prática, e para isso tem que estudar a história do país, conhecer. Então era bom discutir na organização, na direção, para ver se volta esse encontro, se for na Unicamp bem, se não for, pode ser em um assentamento nosso. O importante é que todo ano esteja reunindo a juventude para discutir o andamento da organização também.

Lembro quando ouvi falar do MST pela primeira vez. Foi num aniversário, 12 de maio. Nasci em 12 de maio de 1977. Completei anos antes de ontem! Estava iniciando o Movimento Sem Terra só que a gente não tinha conhecimento. Tinha conhecimento de Valmir, Joel, 
Ademar Bogo, Zé Rainha e Jaime Amorim que estava chegando na Bahia para organizar o Movimento Sem Terra. Lá os fazendeiros começaram a retomar os assentamentos, depois de desapropriado do Governo José Sarney. Aí reunimos todo o povo do assentamento, e o Movimento Sem Terra foi lá junto com nós. Ficamos cinco dias... enfrentamos polícia, pistoleiro, quebramos a sede toda... Esse foi um dos grandes exemplos que teve, para gente conseguir a terra, e ter reforma agrária de verdade. Primeiro tem que ter coragem, porque sem coragem e disponibilidade nunca que sai a reforma agrária. E essa disponibilidade e coragem tem que partir de nós, não do Governo Federal, nem do Incra. Se tiver família, vai ter a reforma agrária. Se tiver a família vai ter que ter o assentamento! E se não tiver, não vai ter nunca.

A tarefa nossa é organizar a família e começou a acontecer no momento em que conheci o Movimento Sem Terra. Com as famílias que sobraram do nosso assentamento... Lembro da primeira bandeira do Movimento Sem Terra, era pequena com letreiro grande, que foi passando para o assentamento. Nós empunhamos e até hoje a gente permanece ainda com a bandeira.

Fui formando minhas idéias... A gente pegava pelo rádio. "O Movimento Sem Terra vai fazer isso, e isso..." Ai fui para o assentamento. Naquele tempo, os assentados iam tudo armado para a área. E um sonho que eu tinha de primeiro era andar armado... contra a polícia, por causa de alguma questão que aconteceu... Aí de acordo com o processo do Jozé. Ai a gente viu que era diferente. Uma visão voltada para a família. E que a mão armada não resolve o problema também.

Quando chegamos no assentamento nosso para conseguir a reforma agrária, o que a gente via era a polícia e pistoleiro armados, contra os pequenos, e que não podiam estar armados. A polícia chegava e desarmava o pequeno e deixava os pistoleiros que estava junto com eles armados. Eu achava que a gente tinha que tomar uma providência, 
trabalhar para estar comprando armas de grande porte para enfrentar. Arma para enfrentar arma. Depois a gente foi ver que não. Que tem que ter gente para enfrentar as armas. Naquele tempo, cheguei a enfrentar pistoleiro... sem arma...

Agora, um ano atrás, no "Abril Vermelho" tivemos a casa nossa, da regional Oeste quebrada. A gente, dentro da cidade e a polícia não fez nada. É, tivemos acampamento queimado... mataram um companheiro nosso... Não foi com tiro. Era uma hora da manhã quando os pistoleiros chegaram e começaram queimando, batendo em gente. Esse companheiro tinha pressão alta, acho que subiu e ele acabou morrendo... A polícia até hoje não fez nada. Foi muito complicado. E a gente sabe que tem que estar caçando uma forma de organizar porque cada dia que passa os fazendeiros estão se organizando. A polícia federal não desarmou os ricos, desarmou os pobres que tinham espingarda velha. Vi em Salvador várias espingardinhas velhas que a polícia recolheu e não recolheu as principais armas que está na mão dos fazendeiros, que permanecem matando gente. Então, depois da campanha do Governo Federal de desarmamento, a gente teve perda de mais de 8 trabalhadores no Brasil do Movimento Sem Terra. Matado por fazendeiros e a gente sabe que não somos nós que estamos armados e que nem a justiça nem o Governo vai fazer nada para desarmar esses trapaceiros que andam por aí fazendo o que faz com a família que luta por um pedaço de chão.

Hoje, a gente tem as ferramentas, instrumentos nossos, que tem que ter. Se chegar 10 pistoleiros armados e tiver 500 famílias organizadas, não vão dar um tiro, nem matar ninguém. Porque tem família disponivel, para estar enfrentando eles. Eles armados e nós não. Um fazendeiro antes de atirar numa pessoa no meio de 500 vai pensar. Pistoleiro para matar um trabalhador, no meio de 100, vai pensar três vezes. Hoje estamos organizados. Não igualmente eles, estamos organizados com famílias corajosas com suas ferramentas, foice, facão e machado, para plantar seu pedaço de terra. 
Então do tempo que queria andar armado, fui percebendo que a tarefa do Movimento Sem Terra não era essa. A tarefa era ajudar a família a conquistar o seu pedaço de chão. E aqueles trabalhadores de primeiro que ia com espingarda, cartucheira... hoje sabe que o perigo é muito grande ter uma arma de fogo dentro de casa. Com filho, com criança, neto... O processo do Movimento Sem Terra na mudança foi conscientizar os trabalhadores de que não é armado que vai estar resolvendo os problemas e que aquela arma pode servir para gente mesmo dentro da casa nossa. Então, esse foi o pensamento do Movimento Sem Terra que adotamos e hoje eu concordo.

Você me pergunta em que momentos me sinto mais Sem Terra. Todos! Lá em casa quando estou dormindo, dentro do acampamento na assembléia ou quando estamos discutindo crédito, dentro do Incra, quando discutindo com o Governo, com o representante do Incra... em tudo quanto é canto. Hoje, não precisa nem separar onde sou menos ou mais.

Fiz curso de formação e fiz o de magistério também. Como disse, atuei primeiro no setor de produção, que era a questão da cachaça dos assentamentos, segundo na frente de massa... terceiro na direção do Movimento Sem Terra. E na coordenação geral do Movimento Sem Terra na Bahia.

Já participei de várias ocupações...

Se eu já fiz mística? Muitas. E gosto! Adoro porque mística é uma conversão que desperta dentro da gente a necessidade de estar permanecendo, construindo. A mística, cada dia que passa você vai construindo. Inclusive depois de amanhã a gente estar participando de uma mística fenomenal! A gente nem sabe direito que papel vai ter... Hoje à noite vou estudar o meu papel. Sei que a mística é o resgate, da cultura brasileira, principalmente na Bahia. Candomblé, índio, isso e aquilo outro... Estamos firme na questão da mística para despertar nos companheiros a vontade de viver e lutar. 
Sobre a preparação da marcha... desde o ano passado que a gente já vinha trabalhando a importância de fazer uma mobilização nacional envolvendo todos os estados. Trazer para Brasília e ficar com cem mil trabalhadores acampados até o Governo decidir resolver o problema e assumir a responsabilidade de assentar o número de família que ele dizia para nós que ia assentar esse ano. E que, às vezes, não teve avanço nenhum. Começamos a preparar, para uma coisa ou outra. Podia ser a marcha, ou um encontro. Esse era o pensamento do Movimento Sem Terra. Em dezembro, nos encontros estaduais nossos, a gente definiu que era a marcha nacional, com dez mil participantes e que cada estado ia ter sua cota. A cota da Bahia foi definida sendo 900 trabalhadores. Então, começamos a preparar. Ia atrás de prefeitura, pedir ajuda para os ônibus. Ia atrás do Governo... de uma coisa e outra... Conseguimos preparar tudo, trouxemos o povo e estamos no final, com vontade de voltar para começar outra marcha de novo! Ah!

No começo não sabia quem vinha. A direção definiu que dos oito dirigentes vinham cinco e ficavam três. Então, ficava sem saber: "Meu Deus, será que vou?" Mas sempre que tinha oportunidade colocava meu nome. Todos queriam vir. Aí no final, faltando 15 dias, com a morte do Papa, sentamos e definimos quem era que vinha, e aí graças a Deus meu nome foi escalado, e participei da terceira marcha nacional. Ficaram dois companheiros e viemos seis.

Como participei das três marchas, escrevi uma cartilha. Agora estou terminando, pegando todo dia de tarde nos tempos de estudo, escrevendo um pouquinho, para depois juntar e ver o que vou escrever quando chegar em casa. Quero fazer uma cartilha que envolva histórias das três marchas, e a diferença na questão das reivindicações. Às vezes, a gente fala "a marcha do MST". Mas qual é a diferença? Por que marchamos em 1997? Em 1999? E 2005? Então, a cartilha que estou pensando em escrever tem esses três momentos.

Em 1997, tinha o Fernando Henrique com o Ministro da Reforma Agrária que queriam acabar com o Movimento Sem Terra e 
fundar o Banco da Terra ${ }^{6}$ para comprar áreas para assentar as famílias. $\mathrm{O}$ que não deu certo. Lutamos para quebrar isso. Com tanta terra devoluta, o governo não pode estar tirando dinheiro dos cofres nacionais, do Tesouro Nacional para comprar terra. Vamos enfrentar o latifúndio e as terras que não produzem têm que ser desapropriadas e divididas. Não compradas!

Em 1999, eram as questões do investimento na educação, na infra-estrutura e questão da Consulta Popular. O Movimento Sem Terra continua pensando na união de vários movimentos sociais no Brasil para construir a Consulta Popular. Ontem, tinha todos pensadores, como Frei Beto, Leonardo Boff, Ademar Bogo, que a gente vinha lendo e estudando junto.

Essa marcha agora é diferente, mais avançada. A de 1999 foi com vários movimentos, essa agora só com o Movimento Sem Terra com uma visão de quebrar várias formas que é criada pela justiça para impedir que o Governo Federal, que Lula, faça a Reforma Agrária. Porque cada área que Lula desapropria eles acham que está dando força para o Movimento Sem Terra. A justiça está investindo pesado com a questão do meio de comunicação, com juizes dos municípios, dos estados, para impedir que a reforma agrária seja feita. Tivemos reunião com Ministro da Justiça e com outros ministros. Essa marcha é mais

\footnotetext{
${ }^{6}$ Em 1999, durante o governo Fernando Henrique Cardoso, foram implementadas a política de financiamento rural do Banco da Terra e do Projeto Cédula da Terra. Esse sistema consistia em um financiamento imobiliário para compra de propriedades rurais, controlado pelo BNDES, usando recursos do Banco Mundial. Esse processo de compra de terras foi apelidado pela oposição de “a reforma agrária de mercado". Isto porque o sistema de juros do empréstimo bancário não respeita o tempo da produção rural e com isso, invertia-se a lógica do uso da terra. A reforma agrária, conforme exige a Constituição, propõe punir o proprietário por não cumprir com sua função social, utilizando suas terras de forma produtiva. Com essa política recompensava-se o latifundiário especulador, garantindo compradores e o pagamento à vista e a preço de mercado, transformando o latifúndio em um ativo financeiro. Segundo FERNANDES e STÉDILE: assim o governo FHC descaracterizava de vez a reforma agrária e mercantilizava a questão agrária. Brava Gente: a trajetória do MST e a luta pela terra no Brasil. São Paulo: Fundação Perseu Abramo, 1999c, p. 141.
} 
ampla. Reivindica educação, reforma agrária, crédito, questão de justiça, tudo junto.

No meio desse trabalho todo, sobra pouco tempo para outras coisas... Tive três namoradas, só que terminam comigo... nunca terminei com nenhuma, terminavam porque achavam que tinha um tempo para o MST e não tinha para elas. De fato, fui parar, pensar e era verdade. É verdade! Mas essa é a questão do militante do Movimento Sem-Terra. Querem que separe um tempo para elas, mas não é fácil, tem que definir lá na região. Às vezes, tem um dia de domingo que a gente está preparado para ir no campo mais ela, aí tem reunião na direção, tem que largar e ir para reunião. Se definir que tem que fazer ocupação no sábado e domingo, vou fazer ocupação e não sei que dia volto. Elas ficam indignadas e terminam comigo.

Agora estou namorando, tem uns dois meses. Trouxe ela para marcha. Mas está com raiva. Não da marcha, de mim! Porque às vezes me chamava: "Vamos tomar banho". Aî, eu falava assim: "Você vai tomar banho, porque agora vou para reunião da coordenação da marcha." Ai ela fica com raiva. Outras vezes, eu estou aqui e alguém fala assim: "Sica, tem que ir lá na cozinha ver um problema, tal, tal..." Aí eu vou. Quando chego na cozinha, não tenho condições de voltar hoje, porque fica longe do acampamento. Então, só volto amanhã às cinco da manhã. Ela fica com raiva pensando que é malandragem da gente... E não é. Quando a gente estava em Anápolis, tive que sair para trazer a coordenação e o dirigente nacional nosso a Brasília. Quando chegou lá, noutro dia de manhã, ele tinha que voltar, eu tive que trazer, quatro e meia da manhã... Cada dia que passa elas acham que a gente está com malandragem, mas não é... É o processo da organização... mas para arrumar uma menina para entender isso, vai dar trabalho. Ela não entendeu. Quero que ela seja do Movimento Sem Terra e que tenha esse entendimento. E que a mesma regra que tem para mim na organização, que tenha para ela também. No dia que ela, quem sabe, assumir uma função no Movimento Sem Terra, vai ter esse entendimento. Se ela for 
para Salvador para voltar amanhã e não voltar é porque algumas tarefas surgiram e ela teve que cumprir. Mas para gente encontrar uma menina com esse pensamento dá trabalho. O sofrimento é muito grande!

Por enquanto estou namorando. Não sei se quando chegar lá, ela vai querer terminar comigo!! Mas, se terminar... ... Tenho amor demais pelo Movimento Sem Terra... Gosto de falar isso porque é verdade! Para amar alguém mais que o Movimento Sem Terra... não sei como vou fazer.

Não sei dizer um melhor e um pior momento da minha vida...

Minha voz está falhando... acho que por causa da tosse...

Ah... tem assim! Tem uns três, que já sei um para falar!

Vivia um momento feliz, na marcha de 1999... Tinha um menino que era de Goiânia, só que gostava muito do povo da Bahia. Todo dia de tarde ele vinha para barraca da Bahia para gente ficar conversando. Quando chegou no rio Araguari, em Minas Gerais, na divisa de Minas e Goiás, fomos tomar banho no rio. Tomamos banho embaixo da ponte porque o rio era muito perigoso. Mas, ele subiu na ponte. Chegando lá tinha uns caras pulando da rua, ele foi pular também. Pulou e sumiu no rio. Encontraram oito dias depois...

Para mim foi o pior momento que tive no Movimento Sem Terra.

Perder um companheiro... Ver e não poder fazer nada, porque quando ele caiu, sumiu de junto de nós... ficamos preocupados, mas foi passando os minutos, aí todo mundo ficou num palavuero. Fiquei com um peso muito grande porque pedimos para ele não subir na ponte.... Ele falou que era acostumado a pular de ponte de outro lugar e que ia pular... pulou... A última vez que vimos ele, foi esse dia. Não vimos mais nunca. Fiquei com aquilo, até o ano passado ficava com aquele pensamento na minha cabeça... Foi um momento muito difícil, de um 
jovem do Movimento Sem Terra que tinha tudo pela frente e acabou em nada!...

Outro momento foi uma questão política, que a gente é muito apegado, no Movimento Sem Terra. Em 1998, lançamos um companheiro nosso na Bahia candidato a deputado estadual, e aí ele perdeu. Tinha que ele ia ser eleito! Nas cidades, onde passava o povo tinha orgulho de falar que o Movimento Sem Terra teve coragem de lançar um assentado para deputado estadual. Lutamos de dia e de noite. Três meses. Aí perdeu... Com 11 mil votos! Fiquei chocado. Era do PT, nosso partido. Partido dos Trabalhadores. Fiquei uns meses desacreditado, achava que foi culpa nossa, de 3 mil militantes na Bahia não conseguir arrumar cada um 30 votos! Fiquei bobo!

Depois, no outro ano, lançamos ele candidato de novo, e ganhou! Em 2004. Aí voltou a alegria! A gente viu que não existe ninguém derrotado hoje. Existe um momento que tem que parar, que sentir que sofreu uma decaída, e que tem tudo para repor aquela recaída que teve. A campanha dele foi nossa, com ele... Serviu de lição. Da primeira vez viu que não deu certo, não pode abandonar. Se é um sonho seu, tem que lutar, para ver se consegue.

Quando era pequeno, pensava ser advogado. Subia naquilo. Com uns 13 anos de idade, ainda estava estudando na primeira série. Pensei assim: "acho que não vou conseguir"... Aí larguei pra lá e pronto. Agora, depois de 15 anos no MST, entrei na escola, estudei, me formei no magistério e vou estudar agronomia. Vou fazer um teste e cursar agronomia no Movimento Sem Terra. Não é mais sonho!

Com o processo de sua vivência, vai vendo o que fazer de sua vida... Cada criança tem um pensamento de ser alguma coisa um dia, e cada criança do Movimento Sem Terra cresce com aquele pensamento. Um pensamento que pode crescer com a organização. O que for conseguido dentro organização, é bom. Se eu conseguir estudar para ser agrônomo, bem, porque vou estar com o povo da roça. Se conseguir 
estudar para ser professor, bem. Se eu conseguir para outra coisa, bem, também.

Meu maior sonho é que um dia a gente tenha assentadas todas essas famílias que estão por aí afora... 


\section{Daniel}

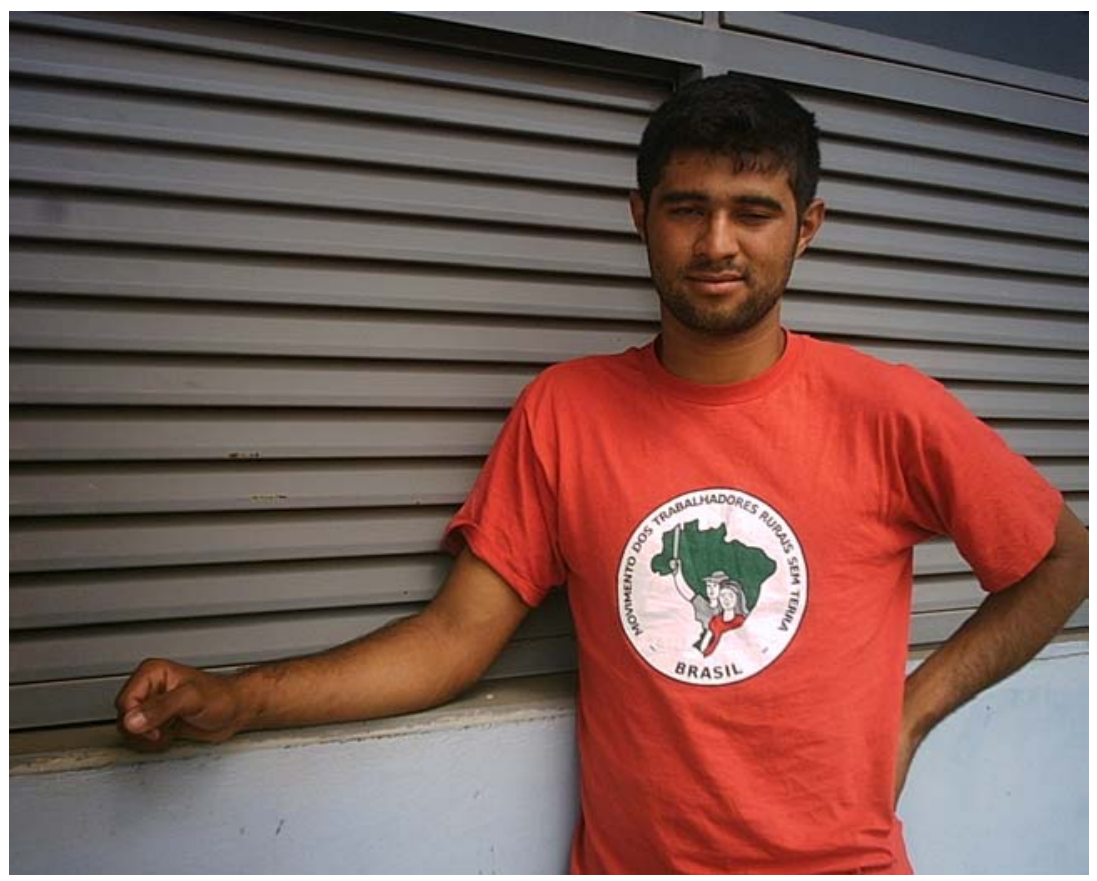

Gaúcho tímido, Daniel foi sucinto. Nosso encontro aconteceu na escola itinerante, montada para acompanhar a marcha. Sentados no chão ao lado da escola ele contou sobre sua trajetória de educador. $\mathrm{O}$ olhar sorria ao falar de boas experiências com as crianças. Os lábios riam ao narrar outras nem tão boas. Emblemático o fato de ter acampado no Incra, em Porto Alegre, se pensarmos em uma vida passada dividida entre campo e cidade.

Entrevista gravada em 12 de maio de 2005. 
O que me fez ficar, acho que foi mais por ser educador.

Sou o Daniel Weber, tenho 18 anos. Meu pai era acampado até pouco tempo, agora ele foi assentado e eu fiquei acampado. O meu acampamento é em Arroio dos Ratos, no Rio Grande do Sul, mas eu estou contribuindo, dando aula na Escola Itinerante na região Sul do estado. Sou acampado na região metropolitana. Estava morando no acampamento do Incra, que não existe mais. Fiquei sete meses dando aula lá. Em fevereiro, a gente fez uma reunião para redividir as pessoas em cada acampamento. Os educadores têm carteira assinada, tudo. Somos contratados pelo Estado e a gente foi redistribuído nos acampamentos. Eu fui para a região Sul e agora estou lá. É um acampamento novo que começou dia 18 de fevereiro. Ele ainda não tem nome, está no município de Capão do Leão.

Tem muita gente que é sem terra, mas não sabe por quê. No passado, seus pais, seus avós eram donos de pequenas propriedades e foram expulsos das terras que tinham. Isso foi o que aconteceu comigo. Meu avô e meu pai eram pequenos agricultores. No Rio Grande do Sul, tem uma reserva que é dos índios e eles foram expulsos de lá pelos indios mesmo. Naquela época, eles não tinham como recorrer a nada, porque a terra era dos índios mesmo. Eu nasci em Planalto, nesse lugar onde nós morávamos. Daí eles foram embora. Meu pai foi morar na cidade, meu avô continuou no interior. Meu pai foi para Novo Hamburgo. Começou a trabalhar, ele é pedreiro. Depois de um certo tempo, veio o cara chamando para ir acampar. Meu pai resolveu ir acampar porque ele já era agricultor e queria voltar para terra. No ano retrasado ele foi assentado.

No Rio Grande do Sul tem que ter 16 anos para concorrer a um lote, para fazer um cadastro. Por isso, eu resolvi ficar acampado para tirar um lote para mim. Faz três anos e meio mais ou menos que 
estou acampado. E eu contribuo na escola, com o Setor de Educação. Dou aula para séries iniciais há quase dois anos.

Eu estou fazendo o $2^{\circ}$ grau agora. Estou terminando naquelas turmas de EJA média - Educação de Jovens e Adultos nível médio - que saíram no Rio Grande do Sul. Mas eu comecei a dar aulas depois de um ano e pouco que estava no acampamento. Agora, faz dois anos que cheguei lá, e fui pegando mais na prática: como se dar aula e quais os conteúdos. Os projetos que a gente tem é de trabalhar a partir da realidade das crianças.

Tem vários aspectos. Por exemplo, uma criança do Movimento que estuda na cidade, vai trabalhar a realidade da cidade, sem estar fechada, ela tem que conhecer a realidade do campo também. Na Escola Itinerante a gente busca isso. O perfil dos sem terra no Rio Grande do Sul, é bastante urbano, porque o pessoal do campo já foi quase todo assentado. Agora o perfil é do pessoal da cidade mesmo, que vive nas vilas, nas favelas. São bastante rebeldes, dá briga, tem envolvidos com drogas, com roubo, esses negócios já apareceram. Por isso, tem que tentar trabalhar a história de vida deles para saber qual a realidade que eles viviam. Talvez uma criança daquelas sofreu muito mais que qualquer um de nós, toda a tua vida. E trabalhar a partir da realidade em que ele está. Como é que vou explicar?... Estou um pouco nervoso e me fogem as palavras...

Por exemplo, não podemos ensinar para uma criança do campo que não conhece o mar o " $b$ " de baleia, afinal ela talvez não conheça uma baleia, ou mesmo o "a” de avião, que ela vê que passa lá em cima da roça. Ela vai ver o avião, mas são coisas muito distantes da realidade dela. Trabalhando mais a realidade delas, as crianças assimilam bastante. Por exemplo, no acampamento você trabalhar o " $\mathrm{b}$ " de barraco, o "a" de acampamento, de assentamento. Partir da realidade é mais ou menos isso. Não que seja só isso, mas é essa base que eu tenho. A idéia é partir do palpável, do concreto, do que você está vendo. Assim a criança entende. 
Falando em história de vida, quando era pequeno eu ia na aula, brincava bastante na terra, no meio do mato. Era uma criança normal assim como as outras. Meu pai era carpinteiro e fazia uns caminhõezinhos para a gente.

Hoje, com as crianças a gente inventa. No meu acampamento tem uma roça de milho, a gente faz boneco de milho, faz colagem. Aprende a fazer brinquedo das coisas que estão ali nos Tempos-Oficina. Se alguma criança tem alguma experiência, alguma coisa para mostrar, tem que deixar ela ser educadora.

Não morava na cidade, morava no interior, em Caxias do Sul, com meu avô. Eu me criei desde pequeno com ele. Era uma pequena propriedade de hortifrutigranjeiro, tinha três hectares e meio. Nós tínhamos horta. Aí nós começamos a trabalhar com isso. Eu não trabalhava fora, trabalhava mais em casa, assim, cuidava das coisas. Quando eu morava com o meu avô, estudava meio turno, depois ia trabalhar, ajudar na roça. O que eu mais gostava era quando andava assim de trator e não fazia nada. Às vezes, meu avô deixava eu ficar andando para lá e para cá, nas terras dele.

Depois que meu avô morreu em 2001, eu vim morar com meu pai na cidade de São Leopoldo. Não era bem na cidade. Como é que eu vou explicar? Eram pequenos lotes, não chegava a um hectare. Quem morava lá era um pessoal mais do campo, criava cavalo, gado, vaca. Meu pai trabalhava na cidade. Com o tempo, meu pai começou a brigar, e ele e minha mãe separaram. Daí meu pai foi morar no centro da cidade, eu continuei morando com a minha mãe. Depois meu pai voltou para casa e veio o cara, o articulador de massa. E ele resolveu ir acampar. Um dia, por causa de umas férias da escola, fui visitar ele no acampamento e resolvi também ficar lá. A princípio eu não estava gostando, mas o meu pai estava meio sozinho. Foi mais de solidariedade a ele. O que me fez ficar, acho que foi mais por ser educador. Por exemplo, eu trabalho com as crianças, e eu gosto de fazer 
isso. É um trabalho gratificante ver a criança aprendendo, se ensinar a ler e escrever.

Antes quando estava fora, não tinha aquele senso crítico das coisas. No começo da luta, a gente entra no acampamento só por um lote de terra. Mas percebe que tem uma luta maior, que é educação, saúde e até mesmo a construção da nova sociedade que a gente quer. $\mathrm{Eu}$ acho que é mais isso. Depois que a gente vai aprendendo. O acampamento é uma escola. A gente vê as coisas, e vai despertando o senso crítico. Vê o mundo como está.

Eu acho que comecei a ver essas coisas no decorrer do tempo, porque no começo eu tinha vergonha de ser sem terra. Eu ia para casa no final de semana, e eu tinha vergonha... eu era bastante criticado, eles ficavam zombando. Mas depois, com o que a gente passa dentro do acampamento, vai aprendendo. A gente vai se descobrindo por esse senso crítico das coisas. Passa a pensar que "morava lá no interior, perdeu a terra", e se pergunta, "mas por que perdeu a terra?" Será que perdeu por perder ou teve influência de alguma coisa? Eu acho que foi isso que fui percebendo.

A minha mãe continua morando na cidade. Só que ela não quer fazer parte do Movimento. Meu pai está feliz, casou de novo. Do primeiro casamento dele, somos em seis irmãos. Tenho uma irmã mais nova com cinco anos, que é filha da minha mãe também. Todos os meus irmãos ficaram com o pai.

Tenho uma relação boa com os educandos, porque convivo o dia inteiro com a criança dentro do acampamento. Não se vê só por meio turno. Elas ficam o dia inteiro com a gente, na barraca da gente e na escola também. As crianças no acampamento não têm muita coisa para se ocupar. Na parte da manhã elas estudam, depois tem os tempos educativos que vão trabalhar na horta e tem Tempo Oficina. 
Queria vir para a marcha. Mas a gente teve a tarefa no estado de vir contribuir na Escola Itinerante e com a Ciranda. A turma nove do magis-tério do Iterra foi designa-da para Ciranda e cada acampamento deslocou um educador. Dentro do meu acampamento foi discutido, e eu queria vir. Tem dez acampamentos

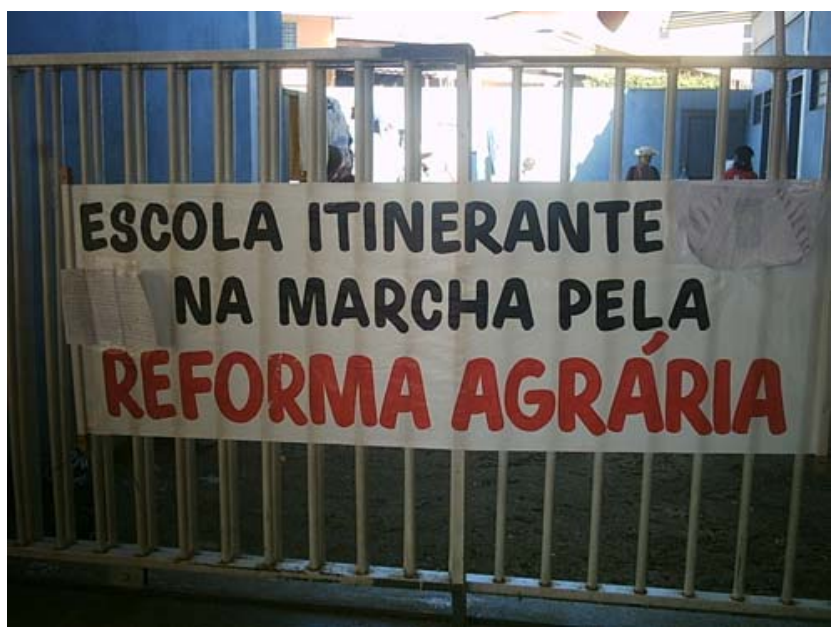
no estado. Depende do número de crianças, se não saísse nenhuma criança do acampamento, não precisa-va ir nenhum educador.

No meu acampamento tem eu e mais dois piás que dão aula, um faz pedagogia e o outro magistério. Aí eles não podiam vir porque tinham estágio para fazer. Daí eu vim. Eu estava com vontade de vir. E foi legal. Uma coisa que deu para perceber é que a Ciranda foi a única equipe que não foi pensada nacionalmente. Cada estado se organizou, e aqui, de uma hora para outra, foi juntando tudo. Isso está sendo legal, a gente está conseguindo fazer, meio improvisado. Está sendo difícil porque não foi pensado que todos os estados iam se juntar, daí falta estrutura. E também porque tem as tuas crianças que tu conhece lá no estado, não convive com elas, mas conhece dos encontros que vai trabalhar na Ciranda ou nalgum outro negócio. Mas aqui é diferente, tem umas crianças de outra realidade diferente. Tem uns que mordem. Tem umas crianças que são muito dificil da gente trabalhar, que a gente não conhece.

Sobre a estrutura, hoje a gente está nessa escola e sempre teve a estrutura mais ou menos como essa. Mas essa foi a melhor que a gente conseguiu. No primeiro dia, a gente ficou no acampamento. Foi organizado lá para gente ficar. Depois, ficou dois dias numa escola de 
umas irmãs em Alexânia. Em seguida, a gente ficou três dias numa outra, escura, lá embaixo, na escola agrícola.

A gente tem dezoito educadores do Rio Grande do Sul e em torno de vinte e seis crianças. Tem bastante educador porque a gente pensou em fazer um rodizio. Para uns ficarem na Ciranda um dia e os outros fossem marchar. Eu já marchei três dias. Foi bom! Mas como tenho o meu joelho aberto, doeu um pouco de noite. Aí não fui mais, fui para a Ciranda.

Tem uma menina que é meio vampirinha, ela disse que é vampira. Quase arrancou um pedaço do meu braço! Ela, ninguém segura. Não sei de onde ela é. Por isso que fica difícil, a gente não sabe, não conhece as crianças. Ela conta que mora só com o pai dela, daí a gente vai fazer o quê?...

$\mathrm{Na}$ preparação da marcha, a gente se envolveu na parte de pensar a escola, a Ciranda. O que ia precisar para escola, o material que ia usar, entrar em contato com as regiões para ver quantas crianças vinham. Mas na marcha, não nos envolvemos, só no processo de educação. A experiência está valendo a pena. Não é sofrido porque sempre aprende a conviver nessa rotina. Muitas vezes, planeja uma coisa, e é totalmente diferente. A gente planejou que ia trabalhar só o estado, com vinte e seis crianças e dezoito educadores. Nove educadores dariam conta por dia de separar a Ciranda e a Escola Itinerante. A gente separava as crianças em idade escolar das que estavam na educação infantil. Não deu certo, mas a gente está improvisando as coisas. A Ciranda é de zero a seis anos. A partir daí, vai para a Escola Itinerante. Tem umas crianças que são maiorzinhas que já têm uma noção de fazer redação, de fazer cartaz e outros tipos de material, de estudar a história de porquê marchar. É isso que a Escola Itinerante está fazendo, uma atividade pedagógica com as crianças que o tema gerador é a marcha.

Os melhores trabalhos estão pregados na parede. Mas eu não estou acompanhando muito a Itinerante, estou ajudando na Ciranda. 
Pois a gente separou, quem queria ficar na Ciranda, quem queria ficar na escola. No estado, eu também contribuo com a educação infantil de vez em quando.

No estado, a Escola Itinerante é reconhecida como uma escola normal, estadual. Somos funcionários do estado. Mas muda com os acampamentos.

O acampamento do Incra era de pessoas que foram para lá porque foi ocupada uma fazenda, e foi dada reintegração de posse. $\mathrm{O}$ pessoal foi em marcha para o Incra até a capital. Lá três acampamentos se encontraram e a gente juntou as escolas todas. A gente ficou lá sete meses, depois saímos de lá. Dois acampamentos ficaram juntos, um retornou para o seu lugar. Mas agora estão os três juntos. É média de tempo, a pessoa que sai no sorteio vai sendo assentada. Foram assentadas umas duzentas famílias no começo do ano.

Tem acampamentos com mais criança que tem ir na cidade e tem outros com menos, para onde a gente é deslocado. Para ser deslocado não recebe nada assim de documentos. A gente só tem que ir à cidade assinar quarenta horas semanais no livro ponto para receber o salário. Tem um convênio com a Secretaria de Educação, por isso tem a carteira assinada.

Por exemplo, quando a gente chegar da marcha, vamos assinar o livro do ponto e essas crianças daqui também que vão ter o caderno, e no diário de classe vai estar anotadas as atividades. Conta como aula normal esse tempo da Escola Itinerante na marcha.

Prestamos contas para a escola base, e ela presta conta para a $27^{a}$ Coordenadoria de Educação que é de Canoas. Isso todo final de ano. As aulas são de janeiro a janeiro, não tem férias. Por esse motivo de ser itinerante. Em tempos de ocupação tem que mudar a aula. A criança sai, vai para base, fica três dias, volta... Só final de ano que a gente tem uma liberaçãozinha de quinze, vinte dias. É dada liberação massiva para o pessoal ir para base, passar Natal, final de ano, e a gente também é liberado. Mas a gente reveza porque tem gente que 
continua no acampamento: algumas crianças ficam e elas não podem ficar sem aula. Daí um educador fica o Natal, e o outro, o Ano Novo. Tem dado certo. Às vezes alguém fica de cara virada, mas é feita a discussão, se a maioria aceitou... A gente vive no coletivo tem que aceitar.

$\mathrm{Na}$ área de educação a gente faz no estado uma vez por ano, uma semana de formação dos educadores. Tem os encontros da Coordenação Estadual onde a gente presta conta do que foi feito nas escolas. A gente participa das místicas de vez em quando com as crianças. No Fórum desse ano, esteve lá com as crianças e vinha o pessoal visitar o acampamento, preparava mística. A mística tem vários significados. Mas para mim, acho que ela tenta passar alguma coisa que aconteceu... O que a gente quer passar para as pessoas depende do tema que a mística trabalha, de como ela é feita, de como ela é pensada. Às vezes tem que estar horas pensando.

É difícil explicar o que é ser sem terra. Como eu vou falar? Acho que bastante gente é sem terra e não sabe.

O que mudou para mim é essa vida no coletivo. Antes não prestava conta para ninguém, vivia lá no meu mundo, fechado. E agora vivo junto com o povo. Acho que aprendi um monte de coisa. Eu gosto de viver assim. Desse ponto de vista, agora acho que eu vivia muito isolado.

Eu acho que na escola lá de fora a gente é educado para o mercado de trabalho. Porque quem não estudar, não consegue emprego. Agora, vai estudar não para conseguir um emprego, mas para você ter conhecimento, para ajudar os outros, para passar para os outros. Eu quero um monte de coisa, mas eu acho que o que mais estou querendo no momento é estudar. Talvez abra uma turma de magistério ou pedagogia. Tanto faz onde. No Rio Grande do Sul, tem o Iterra, o Cefap, que é o Centro de Formação de Aperfeiçoamento, tem um monte desses lá. Quero estudar alguma coisa...

Tenho planos: se tiver estudando, acho que não vou querer 
ser assentado tão logo, e vou deixar o lote para alguém que queira. Mas se eu tiver parado, assim, ainda, talvez eu vá assumir meu lote, tente tocar. Mas não fugir da luta. Continuar no MST. Ainda não penso em casar, nem tenho namorada. A gente muda muito... é itinerante também.

Acho que não tem um momento que eu seja mais sem terra. Eu acho que tem alguns momentos que arrepiam. Por exemplo, numa ocupação, numa marcha, no começo da marcha aqui. A gente fica mais emocionado que em outros momentos. Participei acho que de umas quatro ocupações. Participei também de uma marcha no estado que durou 73 dias. Não fiquei o tempo todo porque nos acampamentos bases que tinha que ficar gente dando aula. A gente revezava de um ir, ficar até um período depois o outro ia. Mas o que eu mais gosto de fazer é ocupação. O melhor é entrar no latifúndio. 


\section{Elizandra}

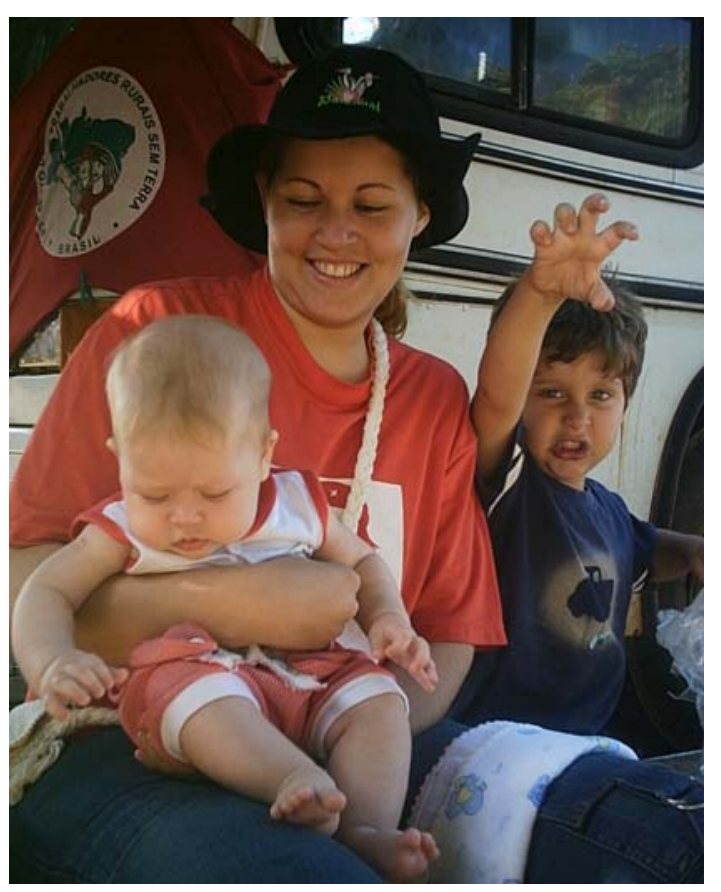

Embalando sua filha nos braços, Elizandra conversou comigo já em Brasília, na chegada da marcha, um dia realmente emocionante. Com sensibilidade, narrou momentos fortes de sua vida, seu despertar para as causas políticas e para a educação. Mesmo sendo liderança, ao trazer o assunto gênero para sua narrativa, fez críticas ao Movimento, ao mesmo tempo que mostrou conquistas realizadas por meio da ação do coletivo do qual faz parte.

Entrevista gravada em 17 de maio de 2005. 
Fomos na festa, o pessoal sempre tratando a gente super bem, uma recepção muito boa. E ai fui mudando... me apegando... vendo aquele povo que eu achava que não trabalhava, não prestava, que eram baderneiros, vagabundos. Foi mudando essa lógica de pensamento...

Sou Elizandra, do Mato Grosso do Sul. Faço parte da Direção Estadual pelo Setor de Educação. Nasci em Dourados, no estado do Mato Grosso do Sul, mas a minha infância, adolescência, um pouco da minha juventude, mais grandinha, foi numa cidade do interior próxima a Dourados, município de Douradina. A minha infância foi maravilhosa, no sentido de que a vida no interior é boa de viver. Digo que foi boa porque tive muito carinho, tanto da minha mãe quanto do meu pai. É muito gostoso. Eu me lembro, tinha três ou quatro aninhos, lembro quando meu pai me colocava na cacunda, assim nas costas, e saía cantando músicas, passeando comigo... me levava para escola.

Essa aqui no meu colo é minha filha, Inara... Ô filha! Não chora não...

Estudei toda a minha infância em Douradina, a minha adolescência. E, na realidade, tive uma infância de brincar de roda, de casinha. Até meus doze anos... Vim de uma família humilde. Meu pai, meus avós, sempre moraram, trabalharam nas fazendas. Meu avô paterno tinha um pedacinho de terra e a minha mãe também. Meus avós, por parte da minha mãe, são do campo, mas eles depois de maiores estavam na cidade, em Douradina. Tenho três irmãos: dois irmãos e uma irmã.

Minha mãe era muito cuidadosa. Pelo menos meu pai e minha mãe souberam dar uma boa educação e deixar a gente ser criança, brincar e ser feliz. Deixava a gente ficar sujinho, mexer com a terra. E depois, na hora do banho que era o chorerê, mas era uma coisa normal, de toda criança. Eu e meus irmãos, acho que a gente não tem o que reclamar nesse sentido. 
Daí veio a pré-adolescência. Cidade pequena a gente conhece todo mundo, tem amigos...

Tinha obrigação: desde pequeno, o pai e a mãe sempre trabalharam isso com a gente. Então, meu pai tinha um bar e minha mãe era professora. Nós dividíamos a obrigação de casa, com a minha irmã que é mais velha do que eu. Ela geralmente ficava com a parte do almoço, de fazer comida, e a gente limpava a casa. Eu ajudava a limpar o bar também. Meu pai e minha mãe sempre falavam: primeiro as obrigações e a escola, depois o lazer.

Estudava no período da tarde, e às vezes no tempinho a gente jogava bola. Eu gostava muito de jogar vôlei. Cidade assim a gente brinca muito. A gente tinha um time, brincava de vôlei.

A gente sempre trabalhou junto. Mas, quando eu fiquei com meus 17 anos, já não era mais um bar, era uma lanchonete, então trabalhava toda a família junto na lanchonete. A minha mãe continuou dando aula. Em finais de semana, porque durante a semana é mais tranqüilo. No final de semana era todo mundo, todos os meus irmãos juntos, a minha mãe, trabalhando no bar para pagar o aluguel da casa onde era a lanchonete. $\mathrm{E}$ também para comprar comida e as coisas para a gente. Sempre tinha quando precisava de alguma ou outra coisinha, porque a gente ajudava. Sempre trabalhamos em familia para conseguir adquirir pelo menos para o sustento família. Não faltava, mas também não sobrava. Batalhava para caramba. $\mathrm{E}$ acho que o importante era que um ajudava o outro.

Toda a minha infância, minha adolescência foi nessa cidade do interior. Quando meu pai e a minha mãe eram jovens, solteiros ainda, moravam no campo. Depois, quando adultos, mudaram para a cidade. Minha mãe perdeu a mãe dela muito novinha, com 14 anos e foi trabalhar na casa dos outros. Ela foi começar a estudar e hoje minha mãe é sucedida, no sentido de que tem uma profissão, é professora. Estudou muito, mas ela teve que batalhar muito também para conseguir se formar, fazer o ensino fundamental, o médio e a própria 
faculdade. De lavar roupa para os outros, de viver na casa dos outros. E meu pai toda vida trabalhando para os outros de peão.

O pai da minha mãe morreu novo. A mãe do meu pai também. Ele era criança. Então, só tinha o avô paterno. A gente sempre morou na cidade depois que meus pais se casaram. Até meus vinte anos. Quando eu tinha 17, 18 anos, por aí, veio como é de costume, os companheiros, um grupo de militantes do Movimento fazer o trabalho de base na cidade. Nisso minha mãe resolveu ir para o acampamento do Movimento Sem Terra, que eles iam fazer no município vizinho, Rio Brilhante. Fica há uns 50 quilômetros de onde a gente morava. Foi ela e um grupo de professores da cidade. Mas, desse grupo, permaneceram no acampamento só a minha mãe e o meu tio. A grande maioria voltou, desistiu.

Nesse período, ela deixou a gente em Douradina. Vinha no final de semana só. Deixou de dar aula. Contribuía no acampamento no Setor de Saúde e de higiene. Ela sempre trabalhou nessa questão das mulheres. Era do movimento de mulheres do Estado. Já tinha trabalhado nessa questão do remédio homeopático, antes de entrar para o Movimento.

Nesse periodo, fui uma vez no acampamento, numa noite cultural. Depois disso, nunca mais voltei. Porque meu pai era contra, ele não aceitava! Dizia que minha mãe não precisava disso. Nós também não éramos a favor. Éramos contra! A nossa vida era aquela ali, para nós não tinha outra vida além daquilo. Nós não acreditávamos em nada disso de Movimento. Não conseguia me ver no campo, na "zona rural". Mesmo sendo de uma cidade pequena, mas estávamos na cidade.

Mas o acampamento mudou. Ficou mais distante. Foi para o município de Nioaque, uns 200 e poucos quilômetros de Rio Brilhante. Aí minha mãe desistiu, voltou, continuou dando aula. Ela tinha um trabalho muito importante dentro do acampamento. Por isso, quando foi no período que estava para sair a terra, o pessoal chamou de volta. "Olha, nós estamos dando uma outra oportunidade"... Perguntaram se 
ela queria tornar a contribuir no acampamento. Foi a segunda vez que a minha mãe deixou tudo, abandonou tudo e foi. Ela levou um sobrinho meu, mais novinho, que tinha dois anos na época. Nesse acampamento minha mãe ficou um ano mais ou menos. Só vinha para casa de vez em quando.

Eu sentia muita falta da minha mãe, porque sempre fui muito apegada com ela e com meu pai. O xodó, porque sou a caçula da turma. Eu não aceitava, porque meu pai falava um monte de coisas... Ele não aceitava... Também, não conhecia nada! Viveu um mundo que é esse mundo aí de muita gente, que não conhece nada só vê o que passa na televisão. Então, automaticamente, vai falar que é um bando de baderneiro, de vagabundo... Eu cansei de falar isso. Porque não conhece.

Dessa história do Movimento em si. Quando foi o período de sair a terra para o sorteio do pré-assentamento, veio eu mais uma amiga minha, com uma turma de Douradina, para festa do corte do lote. Festa de conquista do assentamento. Foi o outro contato que tive. Foi diferente. Tinha aquela coisa... todo mundo gostava da minha mãe, e nos tratavam bem. A gente veio de manhã, de madrugadinha e, no final da tarde, fomos embora.

Continuei estudando em Douradina. Tinha 19 anos. Meu pai naquelas conversas: separa ou não? Por que como vai viver longe? Minha mãe só ia lá de vez em quando... E a gente continua naquela vidinha, a lanchonete...

Por isso eu digo, foi desmontando a família, porque acaba que aí um dos meus irmãos se mudou, foi transferido do trabalho dele. O outro, tinha casado. Foi ficando vazia a casa, só eu, a minha irmã, meu pai mais uma sobrinha minha que é filha da minha irmã. A gente ficava meio sozinho. Meu pai falou que daquela forma não dava mais para se viver. Ele queria descansar. Estava muito cansado daquela vida, porque trabalhar em lanchonete não tem descanso. É de dia correr atrás de cobrar as pessoas, para cobrir cheque, pagar conta, só vivia para isso: 
para pagar conta, cobrir cheque de bebida, disso e daquilo outro. Meu pai cansado, porque saía madrugada da lanchonete, acordava e, noutro dia de manhã, tinha que abrir a lanchonete. A vida era corrida, não era fácil.

Quem acompanhou a minha mãe para o assentamento foi a minha cunhada, que a minha mãe tinha levado o filho dela. Até então a gente não queria ir. Aí meu pai e minha mãe foram se combinando: "vamos ficar juntos! Até o final do ano, no Natal". Não é fácil, acabar com um casamento de mais de 25 anos.

Nesse periodo, eu tinha terminado o meu terceiro ano e estava parada, tinha perdido de fazer o vestibular. Porque no dia que era para fazer as inscrições, não tinha dinheiro para pagar. Pensei: "Deixa, mais para frente eu faço o vestibular... Continuo os estudos".

Então, ficou decidido que meu pai ia para o assentamento com a minha mãe, e eu e minha irmã e minha sobrinha íamos mudar para Aquidauana, que era uma cidade próxima, 60 quilômetros de onde minha mãe estava. Ela era professora no assentamento. Íamos morar na cidade para ver se conseguia estudar e trabalhar. Aquidauana tinha uma faculdade. Assim, quando foi lá para junho, julho por aí, a gente veio embora para Aquidauana. Eu, particularmente, não queria ir embora de Douradina. Porque fui criada lá, toda a minha vida, vinte anos!... Mas... chegamos em Aquidauana e não conseguimos emprego. Então, meu pai continuou com a lanchonete. Ele tinha que bancar a despesa dele e a nossa. Ou seja, duas famílias... e ajudar a minha mãe que estava no assentamento também. Muito gasto! A família, um para um lado, o outro para o outro. Ou seja, espatifou a família. Por isso, quando foi no final do ano, nós fomos todos para o assentamento.

No início de dezembro, meu pai veio com a mudança. Algumas coisas que sobraram da lanchonete, mais as tralhas de casa. Já tinha um pouquinho em Aquidauana. Estava tudo espalhado. Fomos ajuntando o que tínhamos e fomos para o assentamento. Eu não iria ficar no assentamento. Ia passar o período de férias, janeiro e fevereiro, 
e voltar a morar em Dourados na casa de uma tia que tinha uma oferta para mim, de trabalhar num escritório de secretária. Não conseguia imaginar eu dentro do assentamento!

Mas quando nós fomos para o assentamento, a família toda junta! Meus irmãos vieram também... Teve uma festa de final de ano. Assentamento novo, o pessoal sem terra gosta muito de festa. Fomos na festa, o pessoal sempre tratando a gente super bem, uma recepção muito boa. E aí fui mudando... me apegando... vendo aquele povo que eu achava que não trabalhava, não prestava, que eram baderneiros, vagabundos. Foi mudando essa lógica de pensamento...

Uma coisa que me lembro bem era o cuidado com a gente, com o ser humano em si. "Seja bem vindo ao assentamento", o jeito na festa de apresentar a gente. "Ó, essas aqui são as filhas da professora Cida", "Vão vir morar aqui no assentamento junto com a gente". A gente não era acostumado com isso. Minha mãe ia tomar chimarrão na casa da senhora vizinha. Pessoal muito humilde também.

Aquilo para mim era tudo novo. E um pouco sofrido... Para a gente, por mais que antes a vida fosse sofrida - porque tinha que dar um trampo, ajudar desde pequena - comparando com o assentamento, era mil maravilhas. Pois lá sem energia, tinha que puxar a água, para lavar a roupa, para tomar banho, para tudo!... Tinha que buscar água em carriola, na mina, que dava um quilômetro mais ou menos da onde a gente morava. Até então, a minha mãe não estava na casa nossa, dentro do nosso lote. Estava na casa que era da sede. Tinha a sede e tinha várias casas que é normal isso em fazenda. As casas dos antigos peões. A gente ficava numa dessas casas. Todo dia ia para o lote, andava quatro quilômetros... Não era fácil. Nossa! Aquilo para mim era a pior parte. E se tem água para beber, lá era quente! A gente queria assistir uma televisão, não tinha. Tudo assim. Não conseguia me ver naquela vida. Por mais que tivesse coisas boas, para mim isso era sofrimento, porque eu nunca tinha passado por isso. 
Falo que foi minha mãe que me trouxe para dentro do Movimento. Porque, por mais que meu pai sempre falasse e a gente também era contra, ela sempre chegava e falava: "não é isso, o Movimento é isso". Quando vinha para casa, sempre trazia uma novidade. Sobre o que tinha acontecido, os encontros, a disciplina... Ela falava muito da disciplina... Do jeito do tratamento, que um companheiro abraçava a companheira, mas não com segundas intenções. É claro que às vezes tem pessoas que se aproxima por questões afetivas. Para namorar. Mas falava do cuidado de chegar e abraçar o companheiro sem malícias. A gente não tinha muito esses costumes, porque achava que, na sociedade em que vivemos, um homem chegar e se aproximar da mulher, já é com segundas intenções. E a mulher sempre tem que recuar. Por que? Porque senão vai ficar falada. Fui educada dessa forma. Então, a gente ficava meio assim. Só que minha mãe sempre tentando ponderar, tentando explicar. Até que participei da primeira atividade no Movimento, um encontro da juventude. Minha mãe falou: "Vem um ônibus aqui, é interessante vocês irem, participar". Aí foi eu, minha irmã, todo mundo! Foi gostoso de mais. Eu adorei! Tudo para mim era novidade. Tem todo um jeito de trabalhar com jovem, gostava muito de trabalhar a questão da autoestima, do afeto, essa questão dos valores. Tudo eu queria! Aí eu já comprei boné, já queria colocar. Estava naquele momento me apaixonando pelo Movimento! Eu sei que não queria mais parar de participar, depois do encontro. Minha mãe colocava que no assentamento nós tínhamos que começar a participar das reuniões do grupo. Era grupo que eles falavam, não tinha nem essa questão de núcleo de base. Tem que participar do grupo, das reuniões, que a orientação é que tem que participar toda a família. "Vocês estão chegando no assentamento". A minha mãe sempre tacando a gente, colocando a gente para participar das atividades do Movimento. Chamando mesmo. Foi quando eu comecei a participar. As pessoas colocavam a gente porque a gente tinha um pouquinho mais de estudo, tinha o ensino médio completo. Botava a gente para relatar, mas eu 
nem sabia o que era relatar uma reunião, porque a gente não aprende essas coisas na escola.

Quando foi em fevereiro, teve um assassinato de um professor nosso, no Assentamento Andalucia e... os professores foram embora. Mais porque eles não eram dali. O Movimento tem essa prática: se não tem educador, pega de outro assentamento. Desde que a pessoa queira trabalhar lá. Então os dois companheiros que tinha, também estavam retornando para os seus assentamentos. Na realidade era um préassentamento que estava virando assentamento. Eles estavam indo embora. Por isso, estava faltando educador para trabalhar.

Fizeram uma reunião na escola, que tinha um coletivo interno de educação, aí eles colocaram, chamaram a minha irmã e eu, se a gente não aceitava dar aula. Eu sempre falava para minha mãe: "Se há uma coisa que eu não quero na minha vida é ser professora!” Porque a gente via o sofrimento da minha mãe. Não ganha nada, não é valorizado, que o professor não é valorizado dentro do que merecia ser remunerado. E o sofrimento: ficava sábado e domingo mexendo com diário... Não conseguia me ver como uma educadora. A minha irmã aceitou, porque ela adorava matemática, ser professora de $5^{\mathrm{a}}$ a $8^{\mathrm{a}}$.

Eu não ia conseguir me ver de jeito nenhum dando aula. Não aceitei num primeiro momento. Não quis. Disse: "Já estou indo embora do assentamento, eu não quero, eu não vou.” Não conseguiram outros educadores e vieram conversar de novo. Aí minha mãe disse: "Eu te ajudo"; e outra pessoa disse: "eu te ajudo", todo mundo disse que ajudava. Falei, mas eu nem sei dar aula. Era para dar aula de educação física, de $1^{\mathrm{a}}$ a $4^{\mathrm{a}}$ série; de artes, de ciências e de ensino religioso, de $5^{\mathrm{a}}$ a $8^{\mathrm{a}}$. Eu falei, "mas como é que eu vou dar aula disso aí? Eu não sei nem para onde que vai? Eu sei para mim, mas como vou passar para as pessoas? Eu não." Disseram: "No início, vamos colocar para os educandos que um vai ajudar o outro." A minha mãe insistiu: "Fica aqui com a mãe, agora tem o serviço, não precisa estar voltando". Eu também já estava apaixonada pelo MST. Aí aceitei o desafio de dar aula. 
Tem a prática de que os educadores do assentamento têm que participar das reuniões do grupo, dar satisfação para a comunidade. Então, tudo quanto é reunião que tinha, eu participava. Eu ia, e aí levantava o dedo, se prontificava para fazer as coisas. Eu não falava muito, porque estava só conhecendo. Na realidade, tinha medo de dar bola fora, de falar umas coisas que não estava dentro da opinião. Tinha muito medo disso.

Quem me trouxe para o Movimento foi minha mãe. Foi mudando. Meu pai também foi se transformando. Hoje quem olha meu pai não fala. Mudou! Todo mundo muda.

Quando eu aceitei esse desafio, fiquei um ano e meio. Era coordenadora do coletivo interno de educação, participava das reuniões do coletivo regional de educação. Minha mãe dava aula e a minha irmã também. A gente fazia parte do coletivo de educação e meu pai ficava no lote, ele que cuidava, tocava a terra. Meu pai ficava em casa, tocando, mexendo nos afazeres de casa enquanto a gente ia dar aula. A gente ficava praticamente o dia todo na escola. Isso no início do assentamento. A minha vida se transformou, "do roque para o clássico", porque, é uma coisa totalmente diferente. Como não tinha transporte, íamos de manhã cedinho, seis horas da manhã, já estava na estrada para às sete começar a aula. A escola era na sede da fazenda. Não tinha estrada ainda, era uma picada. O quartel estava vindo para fazer as estradas. Quando chegou, nós tivemos que sair da sede para os milicos ficarem alojados... e nós tivemos que construir outra escola de madeira... Então, a escola mudou de lugar.

Era gostoso, mas muito sofrido, ter que ir a pé. $O$ assentamento não era só do Movimento e uma parte era da Fetagri Federação dos Trabalhadores na Agricultura. Eram duas facções. Eu tinha que dar aula lá também. De onde eu morava até lá, dava oito quilômetros, de serra a pé. Um dia na semana tinha que descer a serra 
depois subir no final da tarde para ir dar aula na outra escolinha. Assim, foi um ano e meio...

Recebi o convite de vir para contribuir no coletivo estadual de educação, e me deram o desafio de contribuir na direção estadual pela regional. Eu topei, saí do assentamento, da escola e fui contribuir no estado, pela direção, na regional Pantaneira. O assentamento que meus pais moram faz parte dessa região. Eu fui, larguei tudo. Digo que larguei, porque eu tinha um salário, mas dentro do coletivo não, recebo uma ajuda do Movimento. A gente foi pelo amor à causa porque se fosse pela questão financeira, não iria. Não tinha jeito de ir. Agora a gente está aí até hoje.

Desde quando entrei no Movimento, contribuo no Setor de Educação. Primeiro internamente, como educadora, depois como coordenadora do coletivo interno, depois do coletivo regional e no estadual. $\mathrm{Na}$ direção estadual, a minha tarefa não era só coordenar a questão da educação dentro dos assentamentos e acampamentos, era também o conjunto do Movimento, as linhas políticas. Eu fazia de tudo um pouco.

Para mim, foi um desafio porque era uma responsabilidade muito grande. Dentro de mim, tinha muito medo de errar porque a gente que é mulher sempre é colocada, não pode errar. Se a gente vai fazer uma atividade, tem que se preparar mesmo, porque se errar uma coisinha, a gente é massacrado. Não pode errar! É diferente dos companheiros. Tive que amadurecer na marra, digo assim porque as coisas foram acontecendo muito rápido na minha vida, no Movimento. Em um ano e meio eu já era da direção. Na realidade, não tinha claro qual era o meu papel. As pessoas mais experientes do Movimento sempre colocavam que muitas coisas não têm a dosagem certa, vai ter que aprender na prática, errando e acertando, mas sempre tendo em mente as normas, as linhas do Movimento, os principios. Sempre tive essa preocupação de não errar, tinha muito medo. 
Outra coisa é que a gente foi educada a não falar, e me deparava às vezes de ter que falar numa assembléia porque a gente é da direção, de ter que ir em negociação, numa prefeitura negociar um transporte para uma mobilização, de coordenar, de falar na imprensa. Tudo para mim era... Nossa! Quer ver: até hoje não gosto de falar na imprensa porque acho que eu não tenho as manhas. Mas tem que ir, porque a gente está nessa instância e cada um tem que cumprir o seu papel. Eu procurava estudar muito, ler muitas coisas, para não falar bobagem. Ponderava muito essas questões, mas confesso, não é uma tarefa fácil. E a gente tem muito medo de falar. Nossa!

No início, quando dava aula, tinha aquele medo. Depois vai pegando jeito, as crianças e os adolescentes te deixam muito à vontade. Tinha aluno que era da minha idade. Eu tinha que me controlar, no sentido de me comportar o máximo. Tem que ser exemplo. Até dentro do assentamento. Tem que tomar cuidado porque a gente está sendo vigiada 24h. Chegar numa festa e dançar e... tem que se segurar, controlar. E a gente é jovem, na flor da idade. Nossa! Tive que amadurecer muitas coisas. A luta foi colocando que tinha que ser dessa forma.

Quando entrei no Movimento, eu era noiva. Tinha um namorado e a gente ia casar. Logo que fui para o assentamento, de mês em mês, ia lá me ver. Ele morava em Douradina, então ficava há 200 quilômetros. Toda vez que vinha me ver, queria me levar embora com ele, e eu dizia: "Tenho que ficar com a minha mãe, não deixo a minha mãe de jeito nenhum”. Era noiva para casar, comprando casa, móveis... Só que a minha vida tinha se transformado... não conseguia me ver fora do Movimento. E o meu noivo era de classe média, não gostava do Movimento... Eu viajava para ir para num encontro, uma mobilização ou uma outra coisa. Nessa loucura do Movimento! Mas ele não aceitava essas coisas. Foi onde nós começamos a brigar porque ele falava que eu tinha que largar, eu falava que não. Enfim... Foi nesse vai e vem que acabou noivado. 
Mas acho que isso foi uma coisa que me marcou e ajudou na minha militância, na minha atividade no Movimento. Depois como continuei aconteceu uma coisa que vou agradecer ao Movimento o resto da minha vida. A oportunidade única de ser candidata a uma vaga do curso de Pedagogia da Terra no estado do Mato Grosso. Acho que era a segunda turma de Pedagogia da Terra do Movimento... E eu fui!! O pessoal confiou em mim, me deu essa chance. Como eu disse no início, eu não tive dinheiro para pagar a inscrição. Se não tivesse no Movimento, acho que não tinha uma faculdade hoje.

O curso foi de férias pela Pedagogia da Alternância. A gente ficava 70 dias lá estudando, cedo, tarde e noite. À noite eram questões mais gerais do Movimento, formação, diversos setores, enfim, do conjunto do Movimento. E, durante o dia, são as questões mais da universidade, da grade curricular do curso. Depois do Tempo-Escola que a gente fica lá, retorna e tem o Tempo-Comunidade. Aí vinha um monte de tarefas para a gente fazer no estado, no assentamento, na região. Mas para mim era normal aquilo ali, porque eu tinha que fazer independente do curso porque estava na direção. Tinha que contribuir, fazer as atividades. Mas só que além de eu cumprir as atividades, tinha que fazer relatórios, leituras dirigidas... a Andrea, nossa companheira, que está com você nessa pesquisa também, acompanhou essa fase minha.

Esse curso de pedagogia ajudou muito na minha militância, a questão a evolução do entendimento das linhas políticas do Movimento. Porque lá nós tínhamos oficinas. Tinha que ir para negociação na universidade, tinha que coordenar reunião, núcleo, setor... A forma da organicidade do curso é a mesma do Movimento. Isso ajudava a gente a depois a implementar, porque vai aprendendo na prática. Foi uma fase muito marcante na minha vida, que me ajudou muito e eu agradeço ao Movimento por essa oportunidade de estudar.

Como tinha terminado o noivado, namorava nos encontros, como é normal. Até que encontrei há quatro anos meu companheiro, 
que é do Mato Grosso do Sul. Ele tem 15, 16 anos de Movimento. Nessas idas e voltas, fomos namorando, casamos e hoje tem a Inara, fruto desse nosso amor.

Eu me identifico muito com o Setor de Educação. Hoje, estou na coordenação represento o setor na direção estadual. Gosto muito desse trabalho de acompanhar, ir nos cursos. Tem que estudar, se preparar muito, porque a gente é uma das formadoras do setor. Gosto muito de participar de negociações, de ir nas escolas, de acompanhar as regionais, porque esse é o nosso trabalho.

Isso mal ou bem, porque não é fácil o coletivo. A gente sempre está ampliando, massificando, mas a gente nunca consegue, pois sempre tem uns indo outros vindo. Gosto muito do trabalho que faço dentro do Movimento, porque é em busca, como diz Paulo Freire, de uma educação libertadora. Uma educação diferente desse modelo educacional da nossa sociedade. É nas escolas da cidade que querem colocar as crianças do campo, não respeitando as diferenças, a identidade do povo camponês. É um grande desafio para nós. Às vezes, a gente desanima.

Por exemplo, essa marcha aqui dá uma injeção de ânimo na gente. É uma coisa maravilhosa. Está na história! Vim os quatro dias para terminar a marcha, porque só acompanhando pela internet e pela televisão, minha vontade de vir foi maior. Aqui está o povão. A gente se sente povo e quer vir, quer participar. A gente é Movimento, não quer estar de longe, quer estar perto, junto, vendo chegar. Hoje, a hora que a marcha estava chegando me emocionei. Ver na televisão, em foto é diferente de sentir as pessoas gritarem, o calor humano, esse sentimento que passa. Ver os companheiros, uns com os lábios tudo queimado, rachado, mas estão aí dando palavra de ordem, gritando. Ver mãe com criança no colo, ver as crianças. Só o Movimento proporciona, o cuidado com o ser humano, no sentido de buscar uma sociedade mais justa, mais igualitária, mais fraterna para todos.

O Movimento é constituído pelo povo. E não é fácil trabalhar com o povo, porque a gente nunca vai contentar a todos, sempre vai ter 
aqueles que não vão gostar, que não vão querer daquela forma. Nós temos num grande desafio no conjunto do Movimento que é essa questão da organicidade, massificar e fazer o trabalho de base. Massificar os nossos acampamentos, buscar o povão para a luta. É um desafio essa questão da organicidade que é a participação da mulher, do homem, da família, da criança, não é só participar os homens, mas ter a coordenadora ali junto.

Acho que a parte que não gosto é a parte machista que ainda existe dentro do Movimento. E que é um desafio. Pelo menos está trazendo o debate, discutindo. Essa marcha é o exemplo, mais de 30\% de companheiras participando. Outra coisa que não gosto é que às vezes a gente faz, e ainda tem pessoas que te critica, mas vai tocando porque dentro do Movimento é assim.

Sempre tem aquele que não sabe das coisas e critica sem saber o que está acontecendo. O que eu não gosto dentro do Movimento - que não é o Movimento em si, são algumas pessoas - é o chefismo que às vezes existe. Essa questão de que "faço parte", "mando", "sou maior". Acho que isso às vezes atrapalha. Mas a gente está superando isso, pelo menos estamos tentando. Dentro da organicidade, todos têm a sua tarefa, têm a sua função. Essa participação vai acabando com esse chefismo. Mas infelizmente ainda existe isso em algumas instâncias. Mas tem mais coisas boas do que ruins. Essas são coisas que dá para gente relevar, perto de tudo que conquistamos...

Dessa marcha, participei da organização do antes. Ajudei no estado, nas discussões, no acampamento, no assentamento. Aonde a gente ia tinha que fazer o debate. Do ano passado para cá o ponto de pauta principal era a marcha.

Teve um periodo que fiquei de licença maternidade para ter a neném. Foram uns 40 dias, mas mesmo assim sempre contribuí numa coisa e outra, com a limitação, porque não posso ficar andando mais para todo lado. Mas a gente contribuiu ajudando nas discussões, nas negociações. O que a gente pôde estar contribuindo para acontecer. Não acompanhei o todo da marcha, mas vim no final, porque não 
agüentei ficar olhando pela televisão... Quis vir para cá para sair na televisão!!! Mentira. Brincadeirinha.

Uma mudança que acho importante no Movimento é que se for pegar os companheiros mais antigos, muitos não tinham esse cuidado com a família em si. Porque de fato, tinha que andar para um lado, para o outro. E hoje a gente vê mais preocupação do Movimento, das lideranças, da gente ter um espaço para a família, para cuidar dos filhos, porque são eles os continuadores da história, os sem terrinha. E se não estiver com as crianças, elas não vão entender que têm que conduzir o processo, essa história para frente. Dentro do planejamento, o pessoal tem que colocar um ponto: família. Eu e meu companheiro, a gente discute muito isso. É muito importante, porque somos os dois na militância. Ele é da frente de massa e da direção nacional pelo estado. A gente sempre consulta o planejamento um do outro porque são setores diferentes, tarefas diferentes, mas tem que ter o momento da família. Sim, se não quem cuida da Inara? A gente vai se ajudando, um ao outro. Esse é um ponto que o Movimento está tendo cuidado com a participação da família e a organicidade vem proporcionando isso.

O avanço e a amplitude são pontos marcantes do Movimento, que cresceu demais. Vem crescendo e essa é a maravilha do Movimento. E não é só Brasil. No facão, o Movimento trinchou o mapa para fora do Brasil. Às vezes a gente escuta alguns companheiros que está lá na base e não vê televisão, tem só um radinho, e fica sem saber, não consegue ter essa dimensão maior do Movimento. A gente tenta conversar, colocar essas questões de que tem que olhar um pouco além. Se ficar só naquele mundinho nosso não consegue crescer. Tem que imaginar também. Hoje, está difícil para imaginar o Movimento, porque está muito grande, esticou e a tarefa cresceu junto. Mas é isso: lutar, resistir, produzir e massificar. Acho que esse é o lema principal, é a nossa tarefa de continuar na luta. Com Inara, daqui um tempinho vem um outro sem terrinha.

O melhor momento da minha vida foi o nascimento da Inara. Fico contente só de lembrar. Ela tem cinco meses. Está sendo ótimo 
cuidar dela. Maravilhoso! É uma experiência única ser mãe. Uma dádiva de Deus! E eu agradeço muito por ter dado essa oportunidade de ser mãe, porque é muito gostoso. Às vezes esquece da gente porque o bebê precisa da gente para tudo. Falo que a Inara hoje é minha vida. Não consigo ficar nem meia hora longe dessa menina. Inara, papai da Inara, vovó, vovô são as coisas preciosas da minha vida. Além dos companheiros e companheiras do Movimento.

Acho que é isso. A vida da gente se transforma dentro do Movimento e aprende a viver e a ser gente, porque dá essa oportunidade da gente ser gente, de fazer coisas. Tarefa tem para todos, é só querer. O Movimento dá essa oportunidade que a sociedade não dá para os excluídos. O mais importante que o Movimento proporciona para a gente é o cuidado com o ser humano. A questão do estudo que é o primordial. E as pessoas às vezes não conseguem admitir, um sem terra estudando, "para quê esse povo quer estudar?" Acho esses valores do estudo, da disciplina, do cuidado com o ser humano, os maiores da nossa organização. O Movimento tem muito esse cuidado que acho que é a injeção que vai animando a gente. Às vezes, tem momentos que se desanima... Não vou mentir. Porque as coisas não são fáceis para a gente sem terra. Tudo é mais dificil, porque vem a discriminação da sociedade. Se passa com a camiseta, com boné... pode perceber, as pessoas ficam olhando... Às vezes é discriminado. Nada para nós é fácil, mas temos que mostrar que fazemos parte dessa sociedade e queremos mudar. Acho que esse cuidado é o importante. E a gente não vê aí fora... com as pessoas, os políticos que não têm compromisso com a causa do povo trabalhador. Têm compromisso no bolso deles no final do mês. É muito importante esse cuidado com o ser humano. Acho que isso que é o principal. E acho que foi o que mais mexeu comigo dentro do Movimento. O que me trouxe para dentro do Movimento. Porque foi me cativando com o cuidado das pessoas comigo, desde quando entrei no assentamento. E o cuidado que as pessoas têm um com o outro. A gente está precisando, tem sempre um que pega a criança um pouco, 
nunca deixa a gente sozinha, sempre tem uma pessoa te ajudando, te dando a mão, sendo solidário. É a melhor coisa que tem. 


\section{Luis}

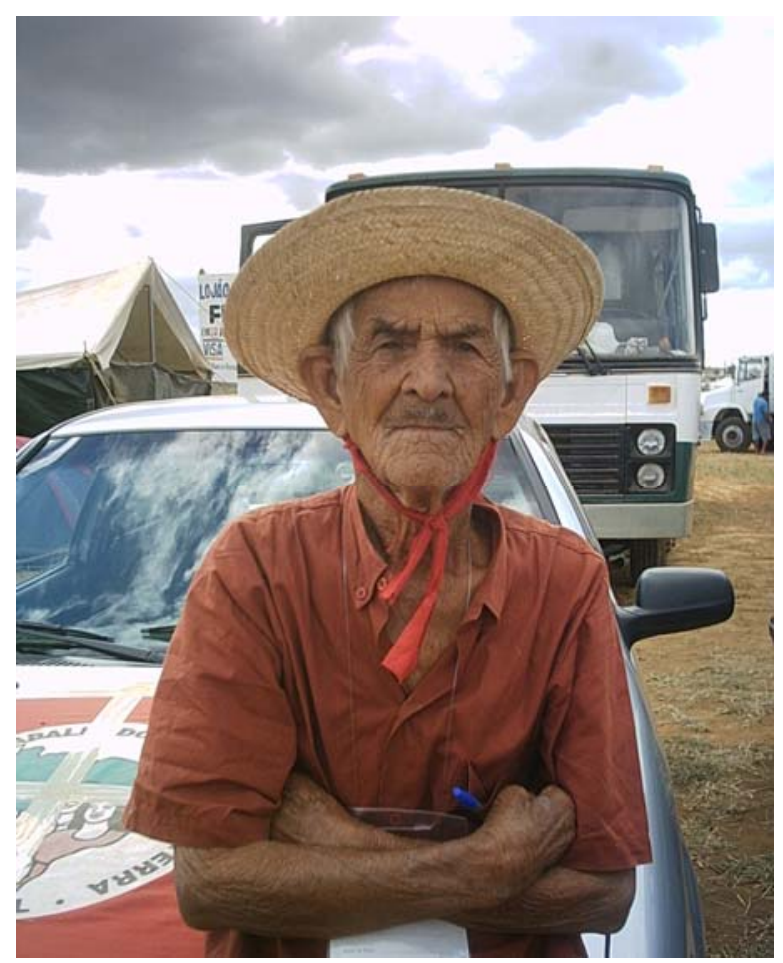

Seu Luis estava acostumado a "dar entrevistas". Por ser o participante mais velho da marcha sua presença é uma mistica. Todos queriam falar com ele e por isso iniciou sua narrativa antes mesmo de ligar o gravador. Fui fazendo perguntas sobre sua vida particular. Assim a família foi aparecendo. Suas respostas, embora bastante curtas, foram fortes e emocionantes. Encostados em um caminhão, gravamos essa densa conversa, indo e vindo, passado e presente... $O$ final desse encontro presenciou outro: dois amigos que marcharam com Seu Luis em 1999 o viram e relembraram alguns momentos.

Entrevista gravada em 14 de maio de 2005. 
Não deixo nada encoberto, porque vou no caminho certo com o MST!

Sou Luis Beltrame de Castro. Estou com 97 anos. Todos os dias marcho um pouco. Não vou de fora a fora, mas vou. Ando... dez ou 12 quilômetros. Até eles chamarem. Minha vida foi só trabalho. Cheguei da Bahia... vim aqui para Ribeirão Preto, fui mexendo com lavoura de cana... e daí saí para a região de Olímpia, lá fui tocar café...

De menino, meu pai foi me ensinar a trabalhar... Não sabia assinar o nome. Meu pai me ensinou a conhecer as letras. Conheci as letras. Peguei estudando com um, com outro... Aprendi a assinar os nomes. Aí fui trabalhar para a roça, para o campo, só trabalhando. Quando é de noite a gente chega cansado, não tinha tempo de estudar. Não aprendi muita coisinha... Assinar o nome, eu assino! Mas, para estar lendo, eu não leio.

Quando foi em 1996, meu filho tinha acampado e já estava assentado. Eu vi que o MST deu condição da gente pegar uma terra... para melhorar de vida. Então, entrei numa marcha. Em 1996, de Campinas a São Paulo, nós gastemos quatro dias de viagem. Daí para cá não perdi mais nenhuma. Fiz a de Sorocaba... a de Ribeirão Preto... Quando foi em 1997, fiz uma de São Paulo a Brasília. Levamos 60 dias de viagem. Teve mais outras, no meio... Está com oito marchas, que eu marcho. Essa não era para vir, era para ficar com medo de vir. Depois falei: "eu vou nessa marcha, porque é a mais preferida para nós... para a luta". "Eles querem, eu vou!" Então vim. Estou andando um pouco, todo dia. Ando uns dez quilômetros. Isso porque não deixam eu marchar mais... Andei 12 um dia. Mas agora eles não querem... para chegar em Brasília mais folgado... descansado... Mas estou aí, hoje marchei um pouco, dali um bocado fui para o carro de som e montei... Chegamos aqui. 
Acho bom marchar... para melhorar o país... A gente fazendo uma força dessa, às vezes, melhora o país. Porque o Lula prometia muita coisa e para nós ele não está fazendo... Quando o Lula perdeu uma vez, ele foi no acampamento e falou muita coisa da reforma agrária. Falou que precisava fazer a reforma agrária e que não era só dar terra, era dar um jeito de tocar a terra. Falou que o agricultor precisava de remédio, estrutura, essas coisas. Ele falou isso. Queria falar com ele, se alembra. Eu lembro do que ele falou. Mas ele, não sei se lembra.

O meu filho é assentado, eu não. Eu não podia pegar mais terra, quando fiz a inscrição, por causa da idade. Estava com 72 anos. Sou sem terra. Mas, agora só quero terra para me cobrir, só preciso de terra para me cobrir! Então está bom...

Sempre vivi na roça. Trabalhei muito em cana, em Ribeirão Preto... Quando fui para lá trabalhava carpindo para o fazendeiro. Como bóia-fria. Pegava empreita, para ganhar mais. Porque por dia, tinha que acompanhar o regime dos dias, e de empreita a gente se esforçava mais, levantava mais cedo para pegar mais trabalho... para ganhar um pouco a mais. Cansava mais, mas ganhava mais. Depois vim para Bebedouro plantando café. Sempre de patrão em patrão... Quando um não dava certo, precisava mudar para outro. E só dando lucro para eles... Só trabalhando e sem ter lucro de nada!

Aí fui para Olímpia, em Cajobi. Ali fiquei... Foi onde eu comecei... Ali eu casei. Fiquei naquela zona 20 anos, trabalhando muito. Casei... criei família lá. Mas os filhos já foram esparramando. Depois fui para Uberlândia, Minas. Morei seis meses ali, mas não me serviu. Queria ir para Goiás, a mulher não queria, porque ficava longe da mãe. Então, voltei para trás...

Minha mulher é baiana também. A gente se conhece desde criancinha... Os velhos é que fizeram esse casamento porque eles queriam. A menina nasceu em 1902, e eu em 1908. Os pais falaram: "olhe, essa menina é para casar com esse menino"... Aí ficou, passou... 
Minha família veio para São Paulo. Depois, passado um tempo veio a dela. Aí nós corremos a reformar o casamento. Casei e se dei muito bem com ela... Vivi 30 anos de casado. Mas... depois ela morreu e ficou um menino para criar.

Nunca mais quis casar. Tinha muita mulher atrás, mas não queria. Tinham muitas loucas que queriam casar comigo, mas eu não quis. Porque pensei: "cria dois amor: amor na mulher, amor nos filhos... Não dá certo". O filho não é dela, a gente fica em rolo. Se ela bater num filho, eu não quero porque é meu filho, então... Ficar com os filhos, com outra mulher, é ruim. Se o filho chega na casa e não acha a mãe, e diz: "essa não é minha mãe!", fica feio. Achei que não estava certo. Não quis.

Quando ficou tudo criado, casado, fiquei sozinho e fui para Mato Grosso trabalhar. Sempre trabalhando com gente. O patrão gostava do meu serviço, do meu jeito de mandar. Então eles diziam: "Luis, você vai fazer um serviço para mim no Mato Grosso". Eu juntava uma turma e ia para o Mato Grosso, ficava lá, 40 ou 50 dias depois voltava para onde eu morava...

No Mato Grosso foi aquela coisa da empreita. Plantava capim, depois ia para tirar as sementes de capim para o fazendeiro. Plantava e colhia a semente para vender. Outras vezes, ele ajuntava o preço e depois fazia a derrubada. Queimava e a gente ia ajuntar aqueles paus para fazer coivara para queimar. Eu reunia com a turma e fazia aquilo.

Depois meu filho pegou terra. Falou: "agora não vai andar, vamos para a terra". Aí fui para lá. O assentamento do meu filho é em Promissão, na fazenda Reunidas. O nome dele é Djalma Beltrame de Castro.

Eu estava com 75 anos quando trabalhei numas fazendas pela última vez. Mas vou dizer... vão achar que não é verdade... eu ainda trabalho na roça. Pego na enxada e ajudo o filho. Ajudo assim... Não vou ganhar nada, vou trabalhando só para ajudar. 
O que mudou na minha vida é que a gente pode ficar mais sossegado. Não precisa ficar vem para lá e para cá, fazendo serviço para os outros e ganhando pouco... Vamos mexer na terra, que dá um frutozinho para gente comer. Dá para sobrar um pouquinho. O que sobra a gente faz qualquer coisa, faz qualquer negocinho. Então resolvi fazer isso.

Aí entrei no MST... e quando tem um negócio para fazer eu vou. Agora saí de lá no dia primeiro. Aí faz um mês que estou fora de casa. Volto para casa e fico contente. Meu filho está contente comigo, já telefonei para lá, está contente lá. Aqui também está tudo bem. Nem fico com muita saudade. Tem mais amor agora na irmandade, na companheirada que a gente aí... Eu chego, é todo mundo: "seu Luis", "seu Luis"...

Todo mundo trata bem, me respeita. Também respeito todo mundo... Se eu fosse fazer 50 centavos por todo mundo que falasse "seu Luis”, eu chegava lá rico! Já pensou, 12 mil pessoas... É um dinherinho bom! Não é!!!

Então, como estava dizendo, acho muito importante marchar. Porque, se não é com marcha, ninguém faz nada. Vejo falar das marchas que Moisés fez, porque lutou 40 anos para poder pegar uma terra... E a primeira marcha que teve foi no tempo de Abraão que ele saiu de Canaã, procurando chão... Desde aquele tempo que era para ter reforma agrária. Antes, quando Deus fez o mundo, não vendeu a terra para ninguém! A terra foi dada! Para o povo trabalhar, para comer, para viver. É isso aí. Essa marcha é importante por causa disso também, porque naquele tempo, 40 anos eles marcharam para ter terra.

No MST, só participei de marchas... Gosto de estar na marcha. Aonde eles me chamam, eu vou. Onde eles falam que precisam de mim. Eu estou por isso.

Tenho feito muitas entrevistas, essa é mais uma entrevista e mais aproveitada para mim. Estou gostando dessa entrevista. Eu gosto de dar entrevista. Não vou fora de dar entrevista. Que quem falar, eu 
falo, se quiser falar mais com ele, eu falo, se não quiser eu não falo também. Eu acho muito importante. Eu me sinto muito importante! A senhora é mais importante ainda... porque é pessoa estudada. Eu sou um analfabeto... Converso mesmo do jeito que aprendi a conversar... do jeito caipira...

Aprendi a escrever com 14 anos. Não sabia nada, fui morar na fazenda não tinha professor e meu pai foi me ensinando a conhecer as letras, “a”, "b", “c”... Depois que conheci as letras, eu peguei a juntar elas para fazer nome. Comecei assim... Nunca tive um dia de professor, numa escola. Eu tinha vontade, mas naquele tempo, as crianças não tinham isso. Quando nós viemos para São Paulo, que começou a estudar um pouquinho, aprender os nomes. Tinha uma vontade de ir na escola, mas miou... A escola nossa, na roça, é trabalhar, é enxada, é foice, é machado, o que fosse. De tudo eu fui! Eu faço de tudo! Nessa escola "da roça" aprendi a carpir, plantar, colher e vender, que é mais fácil... Quando está pronto... é só achegar o preço que a gente está querendo vender.

Tem vez que vendia bem os produtos, tem vez que não dava peixe. Em 1964, quando entrou aquela revolução, tinha muito algodão plantado, mas o patrão foi vender... Fazia uma base de vender o algodão por pelo menos cinco real, não, cinco cruzeiro, naquele tempo. Isso para pagar a conta. Mas baixou, veio para dois cruzeiros por arroba. Aí eu perdi aquela roça. Fiquei cativo do banco, devendo uns tempos, mas depois trabalhei... Paguei, limpei meu nome...

Trabalhava sempre na porcentagem, pagava mais de meia, porque a gente pagava $25 \%$, mas era tudo por nossa conta. Era $25 \%$ para ele e $75 \%$ para mim. Mas não dava porque ele recebia o dele limpinho e nós tinha que comprar a semente, plantar, tratar, colher e dar limpinho a parte dele. Não achava justo, mas a gente não podia falar nada. Não tinha como, tinha que trabalhar. Tinha que trabalhar de todo jeito. Sempre era mais da metade que ia para eles. Eles sempre melhorando a vida e nós sempre para trás. Pior. 
Minha mulher teve... A mulher teve oito filhos!... Morreu um. Tenho sete filhos ainda. E 47 netos! E 64 bisnetos! E oito tataranetos! Conheço todos eles. Eles moram esparramados, mas sempre vejo. Vou na casa de um e de outro. Vejo todos. Só não conheço os que estão escondidos... que ninguém contou que são seus netos, ou bisnetos. Mas aí não dá para saber.

A coisa mais importante da minha vida foi andar direito... conhecer muita gente amiga. Porque se andar torto está arriscado a cair. Sempre andando certo, olha para o chão para ver onde tem toco, para não tropeçar. O melhor é isso! Andar direito, sério, respeitar todo mundo. Quem respeita, tem respeito. O melhor que eu acho na vida é isso.

O mais ruim, foi a morte da mulher, porque é a companheira que a gente vivia junto. Para mim, a pior coisa foi essa... Conhecia desde pequeno... Nascemos no mesmo lugar, em Paramirim na Bahia. A gente brincava, mas não muito junto... Quando é menino, fica com vergonha de estar com uma menina... Ficam dizendo que é namorado. Por isso, pegava e brigava. Dizia: "fulana é isso e aquilo..." A gente não sabia que ia se casar. Os pais que sabiam, mas nós... Os pais que tinham prometido. Mas eu não sabia de nada.

De quando era criança, alembro que gostava muito de cantar... dançar... Tudo isso eu fazia, era meu gosto. Quando desse uma cantoria eu estava lá, para aprender a cantar. Até hoje eu danço e canto. Agora não, mas nas marchas para trás, todo dia nós dançava. Chegava cansado, mas tocava... o lugar era mais plano. Aqui é muito ruim porque não tem jeito. Hoje é bom, aqui está plano. Eu também tocava viola. Mas hoje não estou tocando mais...

E aí cantei muitas coisas. Fazia algum verso. Fazia e faço até hoje. Vou falar para senhora um que lembro, daqui dessa marcha: 
Eu pensei muito... para falar, para escrever o meu nome, para meu nome não esquecer...

Com a verdade na frente e a cara não esconder, e não deixo nada encoberto, porque vou no caminho certo com o MST!

E não é nada de mais, já basta saber conversar,

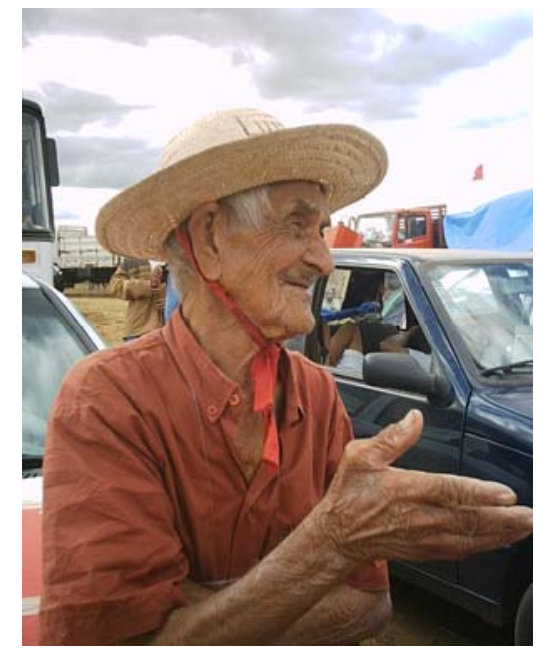
a respeito da reforma agrária, quando a justiça vim procurar porque a reforma agrária é uma lei, não é que inscrição no correios para ficar do jeito que tá.

Porque essa reforma agrária que eles estão fazendo agora é assim: faz a inscrição no correio, que nem Fernando Henrique fez. Todo mundo pode fazer inscrição. Mas a terra até hoje não saiu. Agora vamos ver nessa marcha como é que vai ser. O que é que o Lula vai fazer agora.

Participei da marcha de 1997. Caminhava todos os dias, ia andando de fora a fora. Aí não pegava beira, não. Às vezes perguntavam se eu queria uma carona. Falava: "Não, eu não vim para pegar beira. Vim para marchar!" De São Paulo, saindo da Praça da Sé, a Brasília, não peguei uma beira. Andei o tempo inteiro. A do Rio de Janeiro a Brasília, em 1999, também foi a mesma coisa. Caminhei toda! Ela saiu do Rio de Janeiro, passou em Minas, veio descendo e terminou aqui em Goiás para chegar em Brasília.

Meu aniversário é dia 10 de outubro. Nessa marcha festejaram meu aniversário na beira de um lago. Me deram uma bola, me deram... dois litros de conhaque... Mas eu não bebi tudo... Sempre bebia um 
conhaque... O conhaque fazia bem porque tomando uma dosinha é bom, é fortificante. Então, tomo um conhaque com leite, com mel...

As marchas não têm diferença porque tudo é a mesma coisa. Agora tem esses barracos, aquelas não tinha. A gente ia fazer barraco quando chegava. Montava do chão... Agora está melhor, porque está mais arrumada a marcha. Naquelas marchas antigas sofria muito.

Se Deus quiser, se tiver outra eu venho! Coisa muito bonita a marcha.

Acho importante essa conversa nossa. Porque agora eu fico conhecendo a senhora, e a senhora fica me conhecendo. Para mim é prazer encontrar as pessoas, nessa marcha de 2005. Vim mesmo para encontrar mais companheiro. Tem muitos companheiros que não me conheciam ainda, mas agora ficaram conhecendo. 


\section{Ronaldo}

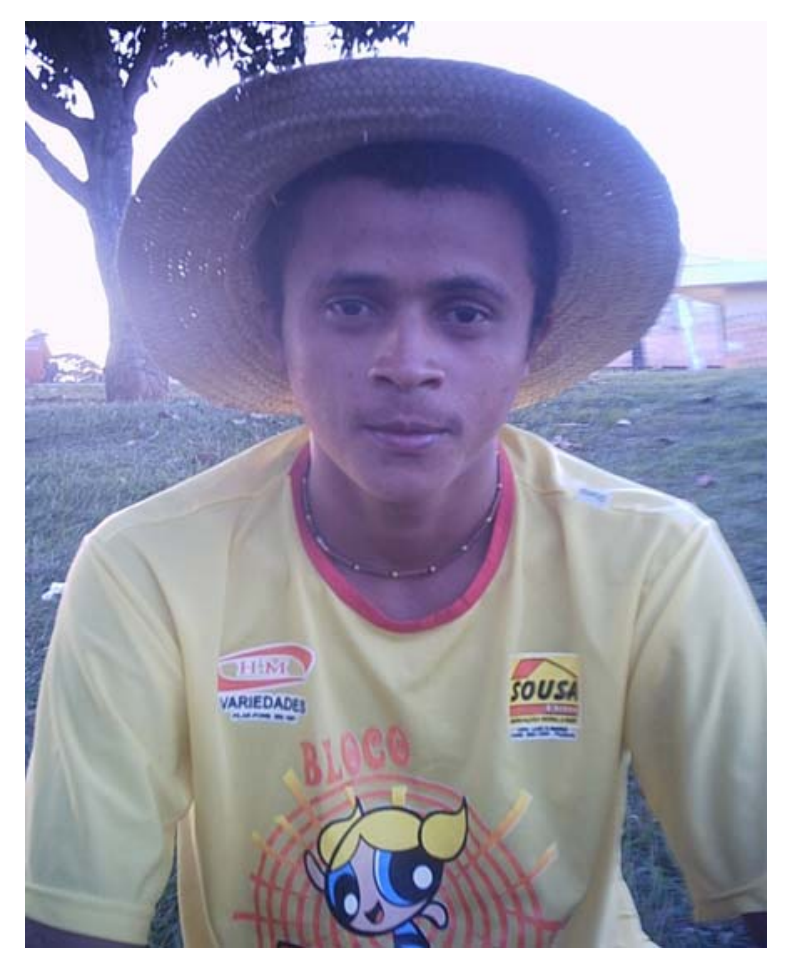

Bem humorado, Ronaldo foi contando sua vida. Paraibano, de sotaque arretado, falou em detalhes sobre seu trabalho no Setor de Frente de Massa, explicando sua forma de organização. Sobre seu passado, contou as dificeis relações de mando que envolvem o cotidiano do trabalhador rural em uma fazenda.

Entrevista gravada em 16 de maio de 2005. 
Depois que nós fomos conhecendo, convivendo, percebemos que a realidade não era aquela que eles mostravam. Fomos tendo mais conversas com as coordenação de lá. E hoje nossa visão é diferente de antigamente.

Sou Ronaldo, moro no assentamento de Tiradentes município de Mari. No estado, tenho a tarefa de contribuir na Frente de Massa, faço parte da coordenação regional. Tenho seis anos de Movimento Sem Terra, desde o acampamento. Em 1999, ocuparam a antiga fazenda de Jindiroba e hoje, nós veve lá. Agora é o assentamento Tiradentes e estou indo no decorrer da luta... Tenho quatro anos de organização, militando. No estado da Paraíba tem seis regionais, contribuí em todas. Tem muita dificuldade de militantes, de uns que aceitam, desafiam a contribuir outros que não.

Muitas vezes, o Movimento Sem Terra vai para a periferia da cidade mais pobre fazer um trabalho, um convite. Conscientizar as famílias para ir para terra. E não foi bem assim nossa história de vida, porque nós morava nessa fazenda. Quando ocuparam a fazenda o proprietário não quis pagar a indenização dos moradores e a solução foi se ajuntar com o MST. Até hoje estamos... Meu pai e minha mãe são assentados. Meu pai é separado da minha mãe. Minha irmã é casada e é assentada também. Cada qual tem seu lote para sobreviver.

A vida melhorou, porque na fazenda só podia criar a soma de três bichos. A gente gostava muito de criar vaca leiteira, galinha capoeira, cabrito... Hoje, quem diz a quantidade são as famílias. Cada qual tem sete hectares e meio, uma parte é para criação uma parte é para roça, para plantar mandioca, feijão, milho. Mas a cultura mesmo, para vender, é mandioca. O ano retrasado deu trinta centavos o quilo. Hoje está doze. Na região a mandioca é boa. Tem outra região que é mais o abacaxi, em outra é o milho, mas nossa região do brejo é mais a mandioca.

Nasci e me criei nessa fazenda. Meus pais, meus avós nasceram e se criaram na fazenda. Meus avós faleceram e saíram da fazenda, sem 
direito a nada. Meu pai ainda conquistou um pedaço de terra, uma casa e está sobrevivendo lá.

Quando o Movimento chegou, tinha treze anos. Só estudava. Cuidava dos bichos que tinha, da vaca leiteira e depois ia para o colégio. Meu pai trabalhava como mecânico na fazenda.

Na fazenda tinha uma sala de aula, mas a escolaridade nossa não tinha. Desde a alfabetização até a $4^{\mathrm{a}}$ série, eu fiz lá. Aí $5^{\mathrm{a}}$ série não tinha mais. A gente deslocava para cidade a bicicleta. Aí depois teve um projeto e veio um ônibus para deslocar as pessoas do sítio para a cidade. Mas quando terminei a $6^{\mathrm{a}}$ série, desisti de estudar. Agora o estado colocou, não é proposta, é obrigação, que todos os militantes têm que estudar. Antes, não tinha como estudar porque vive indo de um canto para outro, fazendo trabalho de base. Porque o trabalho da Frente de Massa é ir para o município convidar as famílias. Então no estado foi formada uma Escola Itinerante. Onde tivesse a equipe de Frente de Massa tem os professores acompanhando, dando formação política. E, nós aprendemos mais. Nesse processo de luta quanto mais formação política para nós, melhor.

Quando ocuparam a fazenda eu mesmo era contra. Eu não concordava com aquilo, porque veja como a elite amostra os movimentos sociais: ela só mostra o lado contrário da organização. A realidade que a gente via nas TVs fazia a nossa visão ser outra. A gente era contra pensando que era um bando de ladrão, baderneiro que entrou lá para tomar a terra do patrão. Não concordava com isso. Nós ficamos a bem dizer obrigados. Obrigados e bravos, porque não tinha para onde ir. Depois que nós fomos conhecendo, convivendo, percebemos que a realidade não era aquela que eles mostravam. Fomos tendo mais conversas com as coordenação de lá. E hoje nossa visão é diferente de antigamente.

Na fazenda, eram 25 moradores. A coordenação do acampamento, umas duas semanas depois da ocupação, convidou todo mundo para uma reunião, uma assembléia com esses moradores para saber a 
posição nossa com eles. E nessa conversa, todo mundo da fazenda não era doido de dizer que era contra. Ficou todo mundo a favor. Eles montaram a coordenação dos moradores. Eu e minha mãe participamos da coordenação logo no início. Dessa conversa, nós fomos conhecendo o companheiro que era dirigente da regional, que era o companheiro Edivaldo. Fomos ficando amigos. Era muito amigo, sempre ia lá em casa, e convenceu a gente a ficar. Nossa briga toda era que o proprietário indenizasse os moradores para ir para cidade, comprar uma casa e conviver lá. Mas até hoje, faz de seis anos de assentamento e os moradores não viram a vela na frente! Não viram uma prata, como dizia o ditado. Só quem saiu de lá foi o administrador que era contra. Ele ainda acionou o batalhão e tentou organizar alguns pistoleiros. Aí os moradores se reuniram e botaram as coisas dele para fora, na marra. Pegaram as coisas dele jogaram em cima de um caminhão. Deram um prazo, ele não quis. Tentava arrumar pistoleiro para ir lá tocar fogo no acampamento, mas ninguém tinha coragem, porque são 160 assentados, fora os moradores. Então são 180. Depois disso, ainda veio um bocado de processo para alguns moradores. Minha mãe mesmo veio processo. Os moradores que ele conhece de nome completo, processou tudinho. Mas nessa fazenda não teve violência, porque o cabra estava falido, pedindo a Deus que alguém tomasse conta.

A minha vida mudou muito depois disso. A juventude hoje pensa em formar um grupo de jovens no assentamento. Não está bem organizado, mas estão pensando em organizar. Na organização quem quer desenvolver a sua própria vida, uma coisa que sabe fazer, tem espaço e oportunidade de fazer aquilo. $\mathrm{E}$ antigamente não tinha a oportunidade nem de estudar direito. Andava mais de quatro quilômetros por dia de bicicleta para poder estudar. Agora os estudos vêm a nós. Isso mudou muita coisa na minha vida.

Eu gosto é de acampamento. Quando forma um acampamento eu fico doido! Eu saí de casa nos meus treze anos para um acampamento, minha mãe não queria deixar eu ir. Eu saí de casa para dizer fugido, e 
fui para essa ocupação e até hoje estou vivendo nos acampamentos no estado.

Eu sou filho de assentado, mas não sou assentado, eu contribuo na regional nos acampamentos, quando tem a necessidade de ter uma pessoa lá ajudando na formação política de cada um, tem uma equipe de oito companheiros, eu e outras pessoas que estão aí, que desloca para lá. Dois, contando comigo três desses ontem embarcamos do estado, para a marcha.

Nós fizemos duas ocupações novas no estado. Esses oito companheiros foram divididos nesses dois acampamentos novos. Quando chego em casa, para passar dois dias, fico doido de voltar para o acampamento. Em casa vejo minha mãe e, agora que sou casado, minha mulher e volto para o acampamento. Porque minha mulher mora com a minha mãe.

Eu tenho 19 anos, me ajuntei tinha dezessete anos. Minha mulher é do Movimento. Os pais dela são assentados no outro assentamento próximo ao nosso. Lá têm três áreas, uma na frente da outra: Assentamento Tiradentes, Assentamento Zumbi dos Palmares, e um acampamento.

A maioria dos militantes que estão aqui era tudo solteiro, agora é tudo casado. Algumas tarefas a gente está tentando encaixar as mulheres na organização. Porque minha mulher e as outras companheiras que são casadas gostam de contribuir também na luta. Em alguns trabalhos de base, nos assentamentos nós levamos elas para puxar a organização dos grupos de mulheres na região. Só não podemos trazer para marcha porque elas estão gestantes. Minha mulher está com seis meses. Estou ansioso para voltar. Mas não vai dar nem para curtir a gravidez. Nós não vamos passar uns dias em casa porque vamos chegar no estado, lá para o dia 21. No dia 26, tem um curso da Frente de Massa. Tipo um seminário que vai durar 20 dias. Tem uma região que é carente, a regional tem muitas dificuldades para tocar. Por isso vai ser deslocado uns 50 militantes de todo o estado para lá, para 
passar dez dias na teoria e dez dias praticando na regional para ver se cresce a região. Porque todas as regionais de lá deram um salto muito grande de qualidade, de acampamento, de desapropriação de terra. E só essa regional que não teve como crescer. Aí a direção do Movimento Sem Terra resolveu fazer um estudo e refazer o melhor para regional. Isso faz parte da luta.

Tem coisa que a gente fica meio triste, como quando vêm algumas avaliações para cima de nós, e nós não cometemos aqueles atos. Na regional, teve uma avaliação que apareceu coisa que a gente não fez. Aí, os coordenadores "pega bonzinho", como diz o ditado, mas não procura saber a realidade da conversa, de onde saiu, porque nossa regional tem uma dificuldade muito grande: um fala da vida do outro. Alguns camaradas, alguns militantes antigos, tudo que eles pudessem fazer para sujar os militantes, para destruir aquela organização eles fazem. São pessoas dos assentamentos. Nós temos muito assentamento rachado. Teve um tempo que o assentamento que a gente convive, foi rachado. Lá dentro não podia andar com o boné do Movimento Sem Terra. De 160 assentados somente 20 ficaram no Movimento Sem Terra. Tem um acampamento pequeno que estava numa terrinha, onde estava tendo conflito. Teve despejo, e nós obtivemos um lote e assentados se mobilizaram, se organizaram e foram expulsar acampamento de lá.

A gente acha ruim porque tudo que a gente faz da militância para algumas bases... As pessoas que são assentadas hoje, amanhã ou depois não contribui com a organização. Podiam dar ao menos contribuição para a organização que é o fomento, para contribuir para comprar uma moto para a regional, estruturar mais a regional... se der briga no estado, para nós poder bancar a discussão. Não vê que o Movimento foi gastando para fazer a ocupação e hoje são assentados por causa do Movimento Sem Terra. Tem camarada que não tem consciência disso. Quando o assentamento acerta de fazer uma 
discussão dessas tem militante que sai meio avexado. Esse é nosso lado negativo que tem no estado.

Antes de nós ir fazer um trabalho na Frente de Massa, passa um dia de estudo, conhecendo a realidade da cidade. Tem apoio na cidade e nós vamos lá passar dois, três meses organizando as famílias dos bairros carentes, convidando porta a porta para uma reunião. Trabalhamos mais com associações e centro comunitário. Tentamos organizar as famílias, que foram cadastradas pelo correio antigamente por aquela propaganda que o Fernando Henrique Cardoso fez. Muitas pessoas têm esperança daquilo. E de conseguir junto do Banco da Terra um crédito fundiário. A gente vai lá tentar mostrar a realidade que não é aquela. Mostrar a realidade da vida das pessoas! A nossa atividade é ir para as cidades carentes com o objetivo de formar acampamento. Quanto mais formar acampamentos, melhor. O estado tem 33 acampamentos. É pequeno ainda. Antigamente, em 2002, tinha mais dificuldade de trabalhar na Frente de Massa, porque esse setor era composto por oito companheiros para andar todo o estado. Era eu e os companheiros Negro, Paulo Sérgio... Mas hoje nós superamos essa dificuldade. Cada regional tem seus dez militantes só para Frente de Massa. Fora o setor de formação, educação...

Como eu dizia, tenta pegar o número de pessoas da periferia que foi cadastrado pelo correio que tem um controle. Depois divide e vamos para a comunidade falando: "Nós estamos convidando para uma reunião de base, somos do MST e vamos dar uma palestra da reforma agrária, sobre o desemprego na cidade". "Muitas pessoas viviam no campo e hoje estão na cidade, e sonham ter um espaço no campo de novo". "A gente está tentando achar uma solução para isso, e está convidando vocês para participar da reunião. Se vocês quiserem ir, estamos lá. Vamos debater isso para ver o que se pode fazer". Muitas vezes, convence... Para o cabra chegar e falar assim fica difícil. Quando tem algumas perguntas fica mais fácil. Mas tem vezes que a gente não conversa, vamos para o corporal. Porque a meta do porta a porta é 
cinco, dez minutos para cada casa. Mas se isso não está atingindo o que nós queremos, pode passar até uma hora, para tentar convencer aquela pessoa a ir para a reunião. Na reunião cada pessoa domina um tema. Um domina o pé da reforma agrária hoje no Brasil, outro a conjuntura do estado ou da região. A gente divide ponto por ponto para cada camarada poder discutir. Cada pessoa já tem uma função, antes de ir para a reunião. Porque senão, deixa frouxo e ninguém consegue alcançar nada.

Tem pessoa que recebe bem e tem pessoa que bota o camarada para correr. Cabra que é contra o Movimento, que é ignorante não recebe a gente. Agora tem pessoa que é simpatizante, que quer ir para o acampamento, elas recebem bem, servem até um cafezinho ou uma água. A gente vai pegando mais intimidade com o povo. Tenta fazer mais amizade nos bairros com presidente de sindicato, de associação, enfim, com as pessoas mais conhecida na comunidade.

Sobre a marcha cada militante teve uma tarefa. Tarefa de conseguir espaço ou algum recurso com a prefeitura, de ir para os assentamentos fazer arrecadação de alimento... Nossa tarefa, minha e de outro companheiro, foi organizar o povo de um acampamento novo e arrecadar dinheiro para marcha. Foi obrigado até a fazer ocupação na prefeitura, porque já tinha marcado umas três reuniões com o prefeito na fazenda Pilar, no município Pilar, e ele não ia para essa reunião. Estava a cargo de pedir a ele algumas coisas para o acampamento também, como lona, alimentação, cadeira para fazer escola da EJA. Aí um dia que a coordenação aceitou nós definimos a ocupação da prefeitura. Nessa ocupação nós alcançamos o objetivo do acampamento e o objetivo da marcha. Aí foi interessante isso, porque só uma coisa resolveu dois problemas. Hoje ele banca todo dia 8 a alimentação para o acampamento novo que tem dois meses. Banca a lona, bancou 50 cadeiras para escola, bancou quadro, essas coisas mais básicas, e bancou mil reais para marcha. 
Às vezes as coisas só saem na ocupação, na pressão mesmo.

Todo dia de vida é importante. Mas, o meu dia mais importante foi a primeira ocupação! Foi na fazenda São Salvador, município de Sapé. Foi muito bonito, a primeira vez que eu fui, madrugada, 300 famílias, em torno de umas 600 pessoas com filho, marido, esposa. E foi muito bonita a ocupação. A primeira ocupação que nós fomos foi interessante. Não tinha o domínio de conversar com as pessoas. As pessoas que vinham da periferia da cidade é que iam conversar conosco. Puxavam a gente para a conversa. Nem na escola eu aprendi tanto. Foi no acampamento sem terra, foi o Movimento Sem Terra que me ensinou a maioria do mundo, do mundo hoje para mim. As pessoa desse acampamento São Salvador tiveram em grande parte contribuição para isso. Me ajudavam em tudo, meus problemas dificeis, problemas pessoais, da minha família. Como eu saí de casa, minha mãe ficou meio apavorada porque eu tinha 13 anos.

Quando chegava lá nesse acampamento, que já acabou, sentava numa fogueira e ficava relembrando os momentos bons e os dificeis. Foi interessante para mim, porque conheci pessoas diferentes, que ficaram marcadas na nossa vida como um amigo, uma amiga. Lá na antiga fazenda que nós vivia, não tinha essa oportunidade de conhecer gente diferente. Igual, está tendo na marcha oportunidade de conhecer pessoas de vários estados, de vários tipos e até fora do país. Por isso esse acampamento para mim foi importante. E hoje é marcado na minha vida.

Lá, as famílias sempre falavam logo as coisas ruins delas, da vida na cidade, que era obrigado a trabalhar a cinco reais por dia. E minha realidade era igual a deles. Meu pai que era obrigado a trabalhar para os fazendeiros para manter a família em casa. Aí eles perguntavam: "Hoje, seu pai vive no acampamento, na fazenda?" Nesses tempos, meu pai ainda estava meio em cima do muro. Minha mãe já estava decidida a ficar no acampamento. A minha dificuldade grande era meu pai que não se definia, se queria ficar no acampamento ou no assentamento. 
Teve alguns amigos, algumas amigas que fui conhecendo, que tiveram a oportunidade de conhecer a minha família e eles convenceram meu pai a ficar. Pelo meu pai ele ia para cidade. Nesse tempo, ele ainda era cabeça dura. Hoje é mais conscientizado das coisas.

O momento mais difícil, que não quero viver mais nunca, e hoje eu tenho fé em Deus que não vou viver mais, é viver em fazenda. Viver obrigado a um camarada que manda em tudo. A gente levava muito esporro do administrador da fazenda. Mesmo a gente que não trabalhava lá.

O assentamento é muito bonito. Logo na entrada tem umas carreiras de manga e de jaca, de um lado e de outro. É muito lindo! As casas são todas divididas. Na fazenda, tinha cana de açúcar e manga, mas não podia chupar uma manga, mesmo que estivesse no chão. Se o administrador, o vigia, visse você chupando, ele botava para fora a manga da sua própria barriga. Era muito ruim por causa disso. Esse momento não quero viver mais nunca e não quero ver algumas pessoas convivendo com isso. Por isso nós estamos nesse Movimento porque tem pessoas que ainda passam por esse processo. Nossa meta é acabar com isso.

Esse administrador não sabia falar com as pessoas. Para ele, a gente era um monte de burro bravo, só ia na volta do grito, nos carão, nos esporros. Não media canto, nem hora, nem espaço para falar. Ficava muito indignado com isso. Nós temos a obrigação de ter respeito com o ser humano, temos a obrigação de ter o máximo de respeito e ele não estava respeitando nós. Tanto que nós, que vivíamos na fazenda respeitávamos ele como chefe.

Tenho algumas boas lembranças da minha infância. Dava para brincar com outras crianças. O bom era jogar bola, lá na fazenda. Jogava muita bola. Logo no início, teve um tempo em que o bendito do fazendeiro cortou o campo para ninguém mais jogar bola. Depois foi deixando. Toda tarde chegava do colégio e jogava bola. Todo final de semana era jogo grande, meninos contra meninas. Lá era bom por 
causa disso também. Eu sinto saudades dessa infância que eu passei. A minha infância foi mais no sítio, não foi bem nas periferias da cidade. Conhecia muito pouco a cidade, somente Mari que é o município da fazenda. Nem a capital da Paraíba não conhecia direito, antes de entrar no Movimento. Ia numa praia uma vez por ano. Fazia lotação e ia. Viam a quantidade de pessoas que iam, alugavam um do ônibus e viam quanto dava por família, uns três, cinco reais. Ia a família toda. Quando chegava na praia, Ave Maria! Era muita alegria! Chegava umas oito horas da manhã e ia até às quatro da tarde sem sair de dentro do mar. Tinha gente que almoçava lá. Mas nós levávamos a comida feita de casa. Era um dia de festa para nós. Passava o resto do ano lembrando Então era muito interessante! $\mathrm{Na}$ nossa juventude, para mim umas partes foi boa e outras foi magoada.

Era difícil outros dias assim, como esse. Na fazenda não tinha festa de São João, porque o camarada não deixava. Agora, no assentamento nosso todo ano tem Festa Junina com a quadrilha que é apresentada na cidade, em Mari, e nos outros sitios ao redor. Quando estou em casa e tenho tempo, eu danço. E gosto. Nossa, é uma tradição boa para nós!

Tem algumas músicas que eu gosto. Agora tem algumas músicas que desmoraliza nós mesmos, desmoraliza principalmente as mulheres. Outras músicas meio sebosas, eu também não gosto.

Participei de um curso de formação. Participei da Escola Estadual, prolongado Escola Nacional Florestan Fernandes. A Escola Estadual foi logo no início quando eu entrei no Movimento. Estava pegando um pouco mais de experiência. O prolongado a mesma coisa. Mas, mais importante desses cursos todos para mim foi a Escola Nacional. Eu fiz o curso em Goiás, em 2003. Peguei mais experiência. Tinha medo, tinha dificuldade de falar na frente de uma multidão de gente. Hoje é mais fácil. 
Quando eu cheguei no estado da Escola Nacional, tinha proposta na direção para discutir meu nome. Se eu iria contribuir no setor de formação, ou ajudar a coordenar o setor de cultura no estado. A coordenação me chamou para ir na direção e perguntou porque eu não queria. Eu disse que eu não podia fazer uma coisa que eu acho que não sou capaz de cumprir. Vou fazer um negócio que gosto, que tenho prática de fazer, que é trabalhar na Frente de Massa. Ir para as periferias da cidade conhecer a realidade. Eu gosto disso. Já coordenei algumas regionais do estado, como o Cariri, o Brejo e a Vazea.

Eu acho que eu já falei quase tudo. 


\section{Wanderléia}

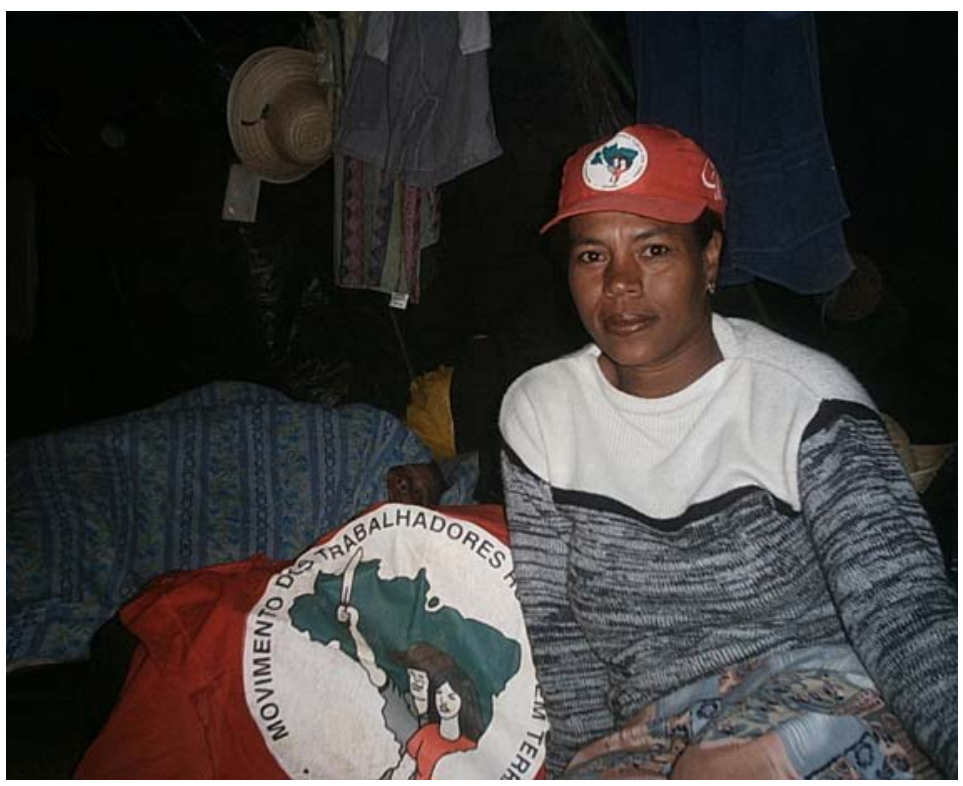

Debaixo de um barraco, assim como tem vivido nos últimos tempos, Wanderléia contou sua vida. Mulher de fibra, confessou momentos de desespero. Sua entrevista mostra uma "volta por cima”. A família hoje está unida por causa da força da mãe e do Movimento.

Entrevista gravada em 16 de maio de 2005. 
O sangue do MST corre na minha veia.

Bom, me chamo Wanderléia, sou do Rio de Janeiro. Morava em Japeri, e conheci o Movimento através de vizinhos, que eu tinha... Sofria muito antes de conhecer o Movimento, meu marido estava desempregado. Eu era doméstica, às vezes tinha trabalho, às vezes não. Tinha três filhos, passava muitas necessidades. Meu marido ficava atrás de emprego, saía de manhã, voltava à noite com fome, cansado e não tinha nem o que dar para os filhos comer. A gente vivia muito apertado... Eu já estava em pânico, quando um vizinho me falou do Movimento, do MST, me convidou para participar de uma reunião.

Fui participar da reunião e chegando lá, conheci várias pessoas. Gostei muito, me senti importante, no meio do pessoal. Aí foram fazer uma ocupação em Pais Leme, isso foi em 99. Fomos para a ocupação, numa noite muito fria... O céu estava estrelado... Chegamos, ocupamos a terra e ficamos lá mais ou menos uns dois anos, por aí...

Mas não deu certo porque o fazendeiro comprou o pessoal do Incra, que foi fazer a vistoria... A terra era improdutiva e eles acabaram comendo churrasco com o fazendeiro, então ficaram do lado dele! Despejados de lá, fomos parar em Santa Cruz, Rio de Janeiro. Ficamos lá uns meses, depois não agüentamos... Era muita bandidagem por perto. Muita favela e a gente com criança pequena... Me apavorei com meu menino, ele estava pequeno ainda, fiquei com medo por ele... Era favelado para todo lado!... E as pessoas não respeitavam mesmo.

Daí, fomos embora para casa de novo e ficamos mais um tempo passando necessidade. Depois a gente já acreditava no Movimento e voltamos para outro acampamento... Onde estamos até hoje. Desde 99 nessa luta! Já ocupamos várias fazendas, passando frio, fome, muita necessidade... 
Daí minhas filhas e meu filho cresceram... A Vanessa que está com 19 anos, tem o Erli que está com 17, e tem a Valéria que está com 14 anos.

Graças ao Movimento consegui fazer o casamento da minha filha. No Manuel Congo, um acampamento que tem em Valença. No ano de 2004, dia 19 de dezembro, minha filha se casou! Aí eu aproveitei casei junto também. Não tinha casado, ainda, não tive oportunidade. Meu marido é o meu companheiro de toda essa luta. Nós temos 23 anos convivendo junto. Agora é que a gente conseguiu casar. Graças ao MST a gente conseguiu realizar!... A companheirada estava toda junta lá no Manuel Congo. Compartilhamos tudo! Pão! Foi muito bom! Muito divertido. Foi um padre fazer o casamento dos dois casais. Eu e minha filha casamos no mesmo dia! Foi muito bom o casamento!

Sei que o Movimento proporciona muita coisa boa. Antes quando estava fora do Movimento não me sentia uma brasileira, uma pessoa importante, eu me sentia... nada!... O Movimento resgatou a minha dignidade!

Nós estamos aqui sofrendo nessa luta. O governo não fez nada até hoje, só prometeu a reforma agrária. Não fez nada por nós. Tem muita gente passando fome, pessoas debaixo dos viadutos... Eles dizem que vão fazer isso, fazer aquilo, mas não fazem nada. Confio no Movimento, que um dia vai haver reforma agrária, se o povo se unir vai haver reforma agrária. Nós estamos cansados, estamos sofrendo muito e eu espero que o presidente compreenda nosso sofrimento. O povo está angustiado, já não agüenta mais sofrer. Fica nessa vida, o desemprego, a miséria, a fome... Espero que ele compreenda que nossa trajetória até Brasília não é briga é pela reforma agrária. Não vamos lá para brigar, "não queremos guerra, nós queremos terra"! Nós estamos cansados dessa vida. É muito sofrimento.

Então me sinto gente no Movimento, me sinto EU, antes não me sentia nada. Não tinha prazer para nada... Agora não, me sinto uma pessoa importante no Movimento. Eu não tenho nem como explicar!... O 
sangue do MST corre na minha veia. Aqui na marcha a gente reparte. No nosso acampamento é repartido tudo, pode ser um quilo de arroz, um quilo de fubá... Quando o governo demora para mandar alimentação, passava tempo de pegar um quilo de fubá botar no panelão, para fazer uma água de fubá para todo mundo. Mais de 100 famílias comer! Ficava aquela água suja, porque não tinha outra coisa para poder sobreviver e agüentar a luta. Já passamos isso.

Queria que o presidente visse isso e passasse pelo menos uma semana debaixo da lona preta para ele ver que durante o dia se botar um bolo você assa e a noite, fica uma friagem... Quando chove é uma tristeza, a gente dorme dentro d'água. Muitas vezes, eu e meus filhos dormiam, assim em pé... Época de natal, de festa, ano novo passava com as crianças no braço e a chuva caindo dentro da barraca. Muitas vezes passei isso. Mas não fui só eu, as outras famílias também. Nesses dias a gente não tinha para onde ir. Passamos muito sufoco, com fome... A barriga roendo e nós lá. Por quê? Acreditando que um dia o ser humano pudesse ter alguma coisa na vida, já passamos muita necessidade.

Isso porque antes eu não tinha nada, antes eu não era, não me sentia nada na vida... Antes, trabalhava de doméstica... Um dia ia trabalhar, outro dia não tinha emprego mais... Chegava na casa das pessoas para trabalhar e era tratada igual cachorro! Só comia se sobrasse a comida. Quando voltava para casa ainda tinha que fazer o serviço de casa, tinha que fazer comida, lavar a roupa tarde da noite para deixar no outro dia para as crianças. Não tinha tempo de cuidar dos meus filhos, nem da minha casa... do meu barraquinho. Porque pobre não tem casa, não dá, não tem como. Era um barraquinho pequenininho em Japeri. Não era uma vida digna! Mesmo trabalhando, quando levantava de manhã não tinha o que dar para as crianças comer, não sobrava dinheiro, porque tinha que pagar água, luz...

Quando as crianças ficavam doentes, tinha que ir para fila do posto de saúde. Tinha que se humilhar para conseguir uma consulta, 
senão voltava com as crianças doente para casa. Sabe o que é uma mãe ver os filhos queimando em febre e não ter como ter socorro? Era tratada igual cachorro! Me sentia humilhada!

Já no Movimento não, é outra coisa. A gente tem chance de aprender, de compartilhar o seu sofrimento com outras pessoas. Pode conversar com elas. Se por algum motivo levanta de manhã e está de mau humor, ou angustiado com alguma coisa, os companheiros chegam, conversam... repartem o pão... Reparte tudo! Não só o pão, como a dor, o sofrimento, qualquer coisa... Ensina as coisas e dá a chance para ser alguém. Se o que a pessoa não sabe é ler, ensinam a ler, dá chance para ser alguém na vida. Veja, jamais eu poderia estar aqui em Brasília, sou do Rio de Janeiro, qual movimento que poderia fazer isso? Me trazer até aqui. Quando poderia conhecer Brasília? Como? Jamais poderia conhecer Brasília. Estou aqui. Graças a quem?

Temos que lutar pelo futuro das crianças, para terem uma boa escola, uma boa educação, lazer e uma boa formação. Tudo isso, nós estamos tentando fazer com que o governo entenda que a nação é de todos, não é só dos ricos, latifundiários. A nação é para todos! A terra é do povo, não é de um só! Quem descobriu o Brasil? Essa história de descobriu o Brasil, aí, está fora. O Brasil foi tomado dos índios! A terra não é para ser comprada, é para ser conquistada! Tem que dar terra para o povo plantar. Tem muita terra e muita gente passando fome. Se o governo desse terra e condições financeiras, ajudasse o povo, não teria tanta fome. Nós queremos terra para a gente plantar, gerar emprego para as pessoas. Para que elas possam ter boas condições de vida, ter um pão na mesa para dar para os filhos de manhã... Poder pagar uma boa educação para as crianças, não escola, que tem que ser grátis. O livro das crianças deveria ser de graça também... Poder botar um filho na faculdade! Imagina, nós pobres poder botar um filho na faculdade!

Então acho que é buscar igualdade para todos... Quando o presidente fala da fome zero, de acabar com a miséria do país... Olha o 
Rio de Janeiro em todo lugar é criança de baixo do viaduto, menina se prostituindo, criança cheirando cola, roubando... Por que que tem marginal hoje em dia? Por que as crianças pequenas estão roubando? Graças a quem? O nosso governo!... Os gravatinhas se dizem "pessoas de bem", mas de bem não tem nada. Pessoas de bem olham para o próximo. Se passar numa calçada ver uma pessoa arriada, caída, rastejando, que vai resgatar aquela pessoa. Não é olhar e fingir que não viu e virar a cara. Não! É olhar e dizer: "fulano, você está precisando de ajuda?". É isso que a gente tem que fazer. Mas eles não fazem...

Acho que o governo tinha que trabalhar mais, não é ficar no escritório, no ar condicionado, tomando água gelada e cafezinho. Não. Tem que sair e se mexer. Botar a mão na massa, não é só falar. Quando tomam posse, falam "vou fazer e acontecer". Não precisa prometer, que não somos santo para ter promessa. É fazer acontecer, é fazer reforma agrária, dá terra para o povo trabalhar e sobreviver. Ninguém aqui está pedindo uma coisa muito diferente, estamos pedindo uma coisa, que é direito nosso. A terra que é do povo, para o povo trabalhar! Quero, que o presidente, os "braços direito" e os "braços esquerdo" dele entendam que o que o povo está fazendo aqui é pedindo a reforma agrária. Não queremos guerra, queremos terra para plantar, queremos uma vida digna! E vida digna é levantar de manhã, os filhos terem um alimento para comer, é não precisar pegar condução para ir para o trabalho longe de casa. Não queremos levantar de madrugada, sair de casa às quatro da manhã e voltar às dez da noite, sem ver os filhos. Queremos ter condições de trabalhar em casa, ver os filhos, criar. Ter a família unida. Poder chegar à tarde, sentar junto com os filhos, com o marido. Poder dar uma educação, conversar com eles. Para não deixar o filho virar um traficante, maconheiro, viciado, alcoólatra... É isso que queremos! $\mathrm{E}$ é isso que a gente quer que o presidente entenda. Queremos um trabalho, não ficar ganhando cestinha básica, que isso é humilhação!

Quando ele tomou posse disse: "Se um dia eu puder fazer 
alguma coisa, a primeira coisa a fazer é a reforma agrária”... Cadê a reforma agrária que ele prometeu? Ele falou, agora é cumprir. Queremos já. Não é para amanhã, é para ontem. Quero que o presidente entenda o nosso sofrimento, que não agüentamos mais ficar debaixo da lona preta. Alguns acampamentos têm anos e anos e não resolveram nada!... Minha indignação é essa, estou cansada de ver as pessoas passarem necessidade, passar aperto.

Por exemplo, quando eu era criança minha mãe e meu padrasto trabalhavam para fazendeiro. Trabalharam a vida toda. Eu tinha sete anos quando fui para companhia do meu padrasto. A minha mãe é mãe solteira, não tive chance de conhecer meu pai... Minha mãe trabalhava em sítio dos outros. A mão da minha mãe era calo puro, parecia a mão de homem... Aquela mão toda estourada. Meu padrasto também. Eles trabalhavam dia e noite, direto, não tinha salário decente... Não tinha nada. Eu não tinha nem chance de ir para escola. Foi depois de grandona que consegui estudar alguma coisa... fiz até a $5^{a}$ série, mais ou menos...

Fui para escola, tinha uns... uns 13 anos, mas aquela coisa assim... Entra na escola e sai porque tem que mudar de fazenda. Nunca consegui aprender nada! Fui crescendo e meus pais trabalhando para fazendeiro... Trabalha aqui, trabalha ali, sempre aquele negócio de meia. A meia é trabalhar assim, um tanto era para o patrão e outro tanto era para o empregado, aquela enrolação quando a fazenda ficava bem preparada, bem plantada, quando estava bem bacana o sítio, eles arrumavam um jeitinho e botava nós para fora. Aí ia para outro sítio... Assim ia. Mas nunca teve um salário digno, decente, a gente passava mais fome que outra coisa. Passava muita fome!

Fui crescendo, crescendo, daí... arrumei meu marido. Tinha o quê? 15 anos, e quando foi com 16 anos a minha filha nasceu, ela está agora com 19 anos. Depois nasceu o menino que está com 17 anos e assim vivendo nesse sofrimento...

Foi aí que saí da casa dos meus pais.Meu marido morava no 
campo, a gente se conheceu lá. Mas eu saí, fui para cidade, tentar uma vida melhor. Meu marido foi tentar emprego de pedreiro, trabalhava numa obra, mas com aquele negócio de contrato de 3 meses, aí parava a obra, e já estava desempregado. Eles não queriam saber de nada não, desempregava a pessoa. Porque passava três meses mandava a pessoa embora para não precisar assinar a carteira. Aí foi trabalhando assim, depois ficou ruim para arrumar emprego, aí a gente fomos morar num sítio. Fomos tentar a vida morando de caseiro, num sítio, com as crianças pequenininhas, morei no sítio um tempão, plantando. Minhas mãos ficava cheia de calo, levantava cedinho ia dormir tarde, não tinha tempo para nada. Foi passando, foi passando, depois voltei para cidade de novo.

Não deu certo no sítio, porque o que ganhava não dava nem para comer, o patrão dava uma miséria, até foi na Serra das Araras que eu trabalhava. Aí o patrão dava muito pouco não dava nem para comprar para fazer a compra da semana... Comprava, quando chegava na quinta feira, já não tinha mais nada para comer dentro de casa, com três crianças! Não tinha mais nada para comer, daí não agüentei, falei vamos embora para a cidade, vou trabalhar de doméstica... Aí arrumei um serviço de diarista, um dia aqui, outro dia ali e assim foi...

Ele foi trabalhando de pedreiro, fez um contrato por três meses, e quando estava completando os 3 meses, falavam que a firma tinha que sair dali... Como é que terminava a obra do prédio em três meses? Dispensaram ele.

Por intermédio do vizinho que chegou e falou: "você não quer participar do Movimento?” e convidou a gente para ir assistir uma reunião, como eu estava dizendo, fomos para assistir a reunião. Chegou lá, a gente gostamos do calor humano que teve, o pessoal falando com a gente, se queria lutar pela terra que não sei o quê, e aí fomos...

Antes de ir para essa reunião, eu ouvia falar mais ou menos do MST. Mas não muito. Ouvia falar na televisão, quando via falar assim: “o MST invadiu uma terra”, "baderneiros não sei o quê". Eu ficava meio 
assustada. Mas minha mãe falava para mim desde criança, nada do que os outros falam você acredita, primeiro você tem que conferir. Aquele ditado: sou igual São Tomé gosto de ver para crer. Aí eu falei, não, vou lá participar sim dessa reunião. Foi passando o tempo, e falei: Vou participar!

É, vou ver como é que é. Aí eu fui numa reunião, aí voltei para casa. Fui eu e meu marido primeiro. Só que arrumamos dinheiro de passagem só para ir, porque tinha que deslocar de um lugar para o outro e tinha que pagar a passagem do ônibus... Aí fomos lá fazer reunião, para ver como era.

Gostamos da palestra, um companheiro lá falou tudo. Gostamos muito. Conversou, explicou... não botou fogo na fogueira, não. Ele falou como é que era o Movimento, falou que se a gente queria participar, que era de livre e espontânea vontade, que não queria, que as pessoas achasse que estava querendo botar lenha na fogueira, mas se a pessoa queria uma terra para plantar...

Gostei, e na próxima vez, fui e levei as crianças, meus três filhos. Vamos lá, seja o que Deus quiser! Arrumamos uma carona com caminhão do vizinho e fomos lá. Chegamos lá, fez outra reunião, conversou de novo, explicou tudinho como que era o Movimento, explicou mais um pouco das coisas, e o que tinha que levar quando fosse acampar. Colchonete, cobertor, que ia passar frio, tinha que levar bastante agasalho para as crianças, se possivel tinha que levar panela, mamadeira se as crianças mamassem, ferramenta de trabalho que era foice, facão, enxadão e martelo. Quem tivesse lona, arrumar lona para levar... Fomos para casa, e ele falou para aguardar e na próxima reunião levar tudo. Fomos na outra reunião, com o vizinho de novo, que a gente não tinha como arrumar dinheiro para ir, aí o vizinho deu carona para gente, botou as coisas tudo em cima do caminhão. Chegamos lá, nem estava preparado ainda, foi em cima da hora, aí, é hoje que nós vamos. Ficamos lá dentro da igreja, um montão de gente, a criançada, criança chorando com frio, morrendo de frio, querendo 
mamar, e, um montão de criança bebezinho, esperando. Aî depois pessoal juntou e falou: é hoje que nós queremos ir.

A gente foi arrecadando alimento, porque no começo o Incra não dá cesta básica. Cada um assim que pôde levou um quilinho de arroz, de feijão, fubá, açúcar, levou sabão, essas coisa para o dia a dia. A gente juntou tudo e fomos lá para Pais Leme. Aí chegou lá de noite, de madrugada, era mais ou menos umas três horas da manhã, entramos para dentro da fazenda, no meio do mato. Todo mundo entrou! Cortamos o arame. Entramos para dentro, foi uma loucura! Estava eu meus filhos! Ainda levamos uma cachorrinha junto!

Uma loucura! É ainda tínhamos uma cachorrinha. Aí demos o nome do acampamento de Terra Prometida. Fico muito emocionada quando falo disso. Foi um momento muito importante.

Ficamos no acampamento, e o pessoal da polícia chegou... E briga daqui briga dali, sai não sai, sai não sai, aí... A gente falava de um lado "Nós queremos reforma agrária, nós queremos terra para plantar" Mas sem desrespeitar. Queríamos a presença do Incra. Começamos a conversar o pessoal da coordenação com os policiais. O pessoal da imprensa veio também, para conversar perguntando porque a gente estava lá, porque a gente estava fazendo bagunça. A gente respondia "a gente quer terra para plantar, essa terra é improdutiva”. O fazendeiro estava com tudo atrasado, as dividas da terra, os impostos. Aí ele começou a pegar boi e botar na terra, sabe, arrumar boi emprestado e colocar na terra, para dizer que a terra era produtiva, mas quando a gente entrou não tinha nada, não tinha um pé de goiaba plantado. Mas mesmo assim tiraram a gente de lá. A justiça é cega mesmo!

Fomos para dentro de um brejo, dormimos uma noite lá, aí choveu no meio do mato. Acordamos com água aqui, ó, na perna. Tudo ficou molhado! Os colchão tudo boiando... Mas insistimos assim mesmo. No outro dia só via gente atolando até as canelas.

Eu fiquei angustiada. A justiça está vendo como estamos sofrendo aqui... Começou dar ferida nas crianças, que a gente ficou 
dentro da lama, então começou a ficar doente, os nariz tudo escorrendo, deu febre, deu pneumonia... O povo angustiado, estressado, naquela friagem... Mas isso foi só para gente se revoltar mais, com a justiça.

Assim mesmo, tirou a gente de lá. Falou que a gente não podia ficar naquele lugar, e botou a gente mais para fora, para a beira da pista. Daí os carros passava, chamava "cambada de vagabundo, vão trabalhar". Eu respondia: "Dá o trabalho, que é isso que a gente quer!" Outro aplaudia, falando que a gente tinha que fazer isso mesmo! Assim foi passando o tempo, sei que a gente ficou lá dois anos. Com mais ou menos uns vinte dias que a gente estava acampado, o pessoal do Incra esteve lá e mandou algum alimento, foi o que deu uma melhoradinha, a equipe de infraestrutura começou a organizar as coisas, fazer banheiro, organizou tudo direitinho... Porque somos pessoas civilizadas também. Tomamos banho no acampamento... As pessoas acham que sem-terra são tudo... sem... Não, a gente tem organização no acampamento. Nós temos capricho! Nós temos coordenação, temos infra-estrutura que é para cuidar dos barracos, temos limpeza, que nós cuidamos da limpeza... Somos contra queimadas, nós juntamos o lixo, temos higiene no acampamento! A gente vive normalmente, igual uma comunidade.

No nosso acampamento não temos uma liderança. Não temos líder, porque quem tem chefe é índio! Lá trabalhamos em grupos, temos uma coordenação, tem o coordenador de saúde, de infra, da limpeza, da educação. Porque nossos filhos estudam! A primeira coisa que organizamos quando chegamos no acampamento é a escola. Mesmo assim é difícil, a gente corre atrás, tem que implorar pela condução, kombi ou ônibus, vir buscar as crianças. A gente tem que se humilhar para que o prefeito mande condução para as criança irem para escola. É um absurdo, criança tem que ficar fora da escola? Não é crime? Mas tem que se humilhar. Tem lugar que eles maltratam o sem-terra. Acham que somos um qualquer.

Estávamos na beira da pista em Dorandia, ficamos lá oito meses, nessa ocupação. Antes disso, estava em Manuel Congo, em 
Valença, fomos para esse acampamento dar uma força um apoio. Ai ficamos lá, onde casei, uns nove meses, mais ou menos. Daí fui embora para outro acampamento Vida Nova e minha filha ficou no acampamento Manuel Congo com o marido dela, que era de lá. Ela e o marido fazem parte do Movimento.

Fui embora para Vida Nova, que o acampamento estava meio vazio. Fomos lá para dar uma força. Como a gente já tem entende mais ou menos, sabe como é que organiza as coisas direitinho.

Aí a gente ocupou uma fazenda em Ipiabas. Estrela Branca o nome da fazenda, no dia 17 de abril desse ano. Depois disso vim para cá, na marcha.

Essa marcha foi falada em todo o país, nossa! Teve uma organização do MST, os coordenadores, pessoal da regional, que escolheram as pessoas para vir na marcha. Um pouco de cada acampamento. Fiquei sabendo que eu ia vir, por um companheiro, o Guilherme que contou para mim! Fiquei super feliz e se fosse preciso vinha de novo e de novo! Vinha com disposição. Espero que da próxima vez seja para agradecer!

Não para pedir, porque é uma coisa que já é direito nosso... Não era necessidade da gente estar aqui pedindo.

Essa é a primeira manifestação grande do Movimento que participo. Fora as ocupações. Já participei de muita manifestação no Rio de Janeiro, contra o leilão da Petrobrás... Participei contra os transgênicos, também.

Já fui no Incra. Reivindicar os direito nossos, que é um absurdo pedir uma lona para cobrir a barraca, alimentação... Para eles trabalharem, fazerem alguma coisa que estão muito paradinho... Para fazer a coisa funcionar, tem que ser com pressão? Tem que catucar. Por isso fomos, dormimos, e moramos no Incra...

Já participei de muita manifestação no Rio, fechamos estrada. Ih!... Já participei de muita coisa, eu venho participando não é de hoje... 
Digo que o sangue do MST corre na minha veia. E quando estou nas manifestações me sinto... nossa me sinto enfeitiçada! Me sinto gente! Quando estou no Movimento, me sinto importante! Cada um de nós aqui é importante! O calor humano que tem entre nós!... Aqui repartimos tudo. Até se um companheiro precisar chegar para dormir no chão aqui na friagem, no colchonete, embola e dorme. Compartilhamos o pão, a água, banheiro, tudo nós compartilhamos, aqui! Não temos orgulho, somos tudo unido! Se compra uma bala, a gente parte. Aqui a gente se sente uma família! Imagina quantas pessoas tem aqui, quantas mil pessoas tem aqui. Mais ou menos 10 mil pessoas! Quando as mulheres vão para o banheiro tomar banho é todo mundo junto, não tem diferença de cor, de raça, como é que se diz, de lugar, de língua, não tem nada! É união! É aquela coisa calorosa! Uma coisa muito boa, as pessoas aqui não são orgulhosas.

Me sinto bem, me sinto ótima quando estou no Movimento! Apesar de estar muito gripada, porque a gente pegou uma gripe terrivel. Espero que o presidente compreenda que nós não estamos brincando, não. Tomando friagem, levantando de madrugada, caminhando esse tempo todo... Muita gente passa mal, minha filha esses dias passou mal a beça. Estou com a minha família inteira aqui. Meus três filhos, meu marido e meu genro. Caminhamos juntos. Para ver, como é que é a luta.

A coisa que mais gosto de fazer, que mais me sinto bem é quando a gente reivindica os direitos. Antes de ir para o Movimento eu tinha medo de por exemplo, entrar numa fila e pedir alguma coisa. Eu queria brigar pelas coisas, mas ficava com medo. Me sentia uma formiguinha!... Me sentia assim pequenininha! Um nada... Agora não, eu sei dos meus direitos, chego num lugar sei que eu tenho direito e vou reivindicar.

Agora sim, eu me sinto gente! Me sinto uma pessoa de verdade, um ser humano! Me sentia um lixo antes de entrar para o Movimento... Agora me sinto um ser humano, uma pessoa de verdade. Muito melhor! 
Nossa, não tem comparação! Apesar que cada um de nós tem um temperamento, temos nosso jeito de ser, nós tudo erramos, mas mesmo assim somos uma família, cada um de nós tem o nosso jeitinho de ser. É um calor humano! Uma coisa muito bonita. Valorosa! Não tem explicação, não tem como distinguir... Não tem palavras. Não tem mesmo, é uma coisa muito boa!

Mudou tudo na minha vida, tudo! Antes eu levantava de manhã, passava o dia e não tinha uma pessoa para conversar, não tinha ninguém para desabafar... Eu ficava muito deprimida em casa... Meu marido saía de manhã para ver se arrumava trabalho, eu ficava deprimida dentro de casa, não sabia o que fazer. Ficava angustiada... Já tive até vontade de morrer!... Teve uma época que cheguei a tomar veneno, porque eu me senti muito humilhada... arrasada... Eu pensava assim, em acabar com a minha vida e acabar com a vida dos meus filhos, uma época... Pensei em morrer!... Em acabar com tudo... Estava cansada desse mundo... Pensava assim: "já não agüento mais! Levantar de manhã, não ter o que dar para os meus filhos..." O dia inteiro aquele sufoco... Olhava para o armário não tinha nada para fazer para comer. E as pessoas era "bom dia"! Mas não tinha com quem se abrir, não tinha ninguém para dividir aquilo que eu estava sentindo!... Eu acordava, me sentindo mal... Meu marido saía de manhã, eu ficava arrasada... Aí falei: vou morrer!... Quando meu marido saiu, peguei um copo botei um pouco de chumbinho, olhe só, aquele veneno de rato... Mas Deus foi tão grande, tão bom!... Porque eu pensei em dar para as crianças, eu ia dar para eles não dei, eu mesma tomei aquilo, fui parar no hospital, fiquei em coma.

Eu sentia arrasada porque a gente não conseguia ir para frente, não conseguia, não é melhorar de vida, ficar rico... Mas ter uma vida mais decente... Eu não conseguia, não conseguia... Minha mente ficou tão ruim que eu pensei em acabar com tudo.

Aí meu marido chegou, me achou arreada no sofá... Eu vomitava, botava por baixo e por cima. Aí ele me levou para o hospital, 
não sabia o que estava acontecendo comigo. Chegou lá o médico falou que eu tinha tomado veneno e que ia ver o que podia fazer por mim. Fiquei desacordada, e só no outro dia acordei. O médico foi conversar comigo falei que estava cansada dessa vida. Falei com ele que não agüentava mais ver meus filhos passar fome e que entrei em pânico. Meu marido ficou louco, quando me viu daquele jeito!...

Mas aí parece que Deus me deu uma luz, que aí eu consegui... Conversando com o vizinho, com a vizinha, eles falaram "vamos participar de uma reunião?”. Por isso estou aqui... Desde 99.

Não é fácil, não! Uma luta muito grande! O povo sofre...

Lembrança pior, que tenho desse tempo é das crianças falarem: “mãe, não tem nada para comer não?” Não gosto nem de lembrar!

Nunca mais isso aconteceu. Nunca mais! Depois que a gente entra para o Movimento, tem umas pessoas a nosso favor e outros contra, mas as igrejas ajudam muito, nunca deixa faltar coisas para as crianças... Vivemos de doações. No acampamento a prioridade são as crianças e os idosos. Então qualquer coisinha de bom, de diferente que chega a gente logo reserva para eles, se sobrar, vai para mais gente. Mas pensa primeiro no "futuro da nação".

Mais uma coisa que eu tenho lembrança triste é o marido sair quatro horas da manhã e chegar de noite, falar que não arrumou nada. Com os olhos fundos, de quem não almoçou, não tomou café de manhã, não comeu nada o dia inteiro... Chegar até com diarréia de desidratado, porque na cidade não se dá um copo d’água, no Rio de Janeiro... Banheiro é pago!... Ver meu marido passando mal de franqueza, não ter o que comer e dormir sem saber o que fazer no outro dia!... E falar assim: "mulher amanhã só volto se eu arrumar alguma coisa, se não arrumar não volto aqui nunca mais, não volto enquanto eu não conseguir algo". Triste isso, eu não sabia o que responder!

Mas a vida me trouxe alegria, também! 
Acho que os 20 anos do MST que foi uma comemoração muito boa. Teve uma festa em vários lugares. Na festa que eu fui teve todo mundo, o povo tudo junto, é aquela comemoração, é homenagem às pessoas que ajudam a gente, como o Betinho.

Essas homenagens são as místicas. Cantam música, chamam as pessoas na frente e homenageia. Por exemplo, entregam a bandeira, o boné e aplaudem as pessoas que são homenageadas. É um calor humano, é muito bom... As festas do MST.

O MST não é rico, a nossa riqueza é a união.

Eu me lembro de uma mística que me tocou lá no Manuel Congo, quando o acampamento fez um ano. A gente fez uma festinha e uma mística, que homenageava os amigos do Movimento. Fez uma mística, com a gente entrando na terra, parecia que estava vivendo aquilo de novamente!

Também um momento feliz da minha vida, foi de casar a minha filha no Movimento sem pagar nada, com a ajuda do povo, dos amigos. Para a festa todo mundo ajudou, as pessoas da cidade, os amigos do Movimento, os advogados... Cada um doou o que pôde, não foi uma coisa chique não... Mas um arrumou o altar, outro levou um saquinho de pipoca, outro um pacotinho de arroz, um pacotinho de farinha, uma lingüiça para fazer uma farofa... Foram coisas simples.

Com o pessoal que estava lá eram umas 120 famílias, com mais o pessoal de fora, acho que tinha umas 300 pessoas, por aí. Foi muito bonito casar uma filha no Movimento, sem pagar nada com a ajuda do povo. Então, isso foi um momento muito bom, me senti a mãe coruja de tão feliz. Não sei nem explicar!

No acampamento, levanto de manhã e a primeira coisa que a gente faz depois de acordar é escovar os dentes, depois vai para reunião, dia sim, dia não, tem reunião. A gente faz parte da coordenação. A reunião é para organizar o dia, quem vai fazer o quê, o quê tem de trabalho no acampamento. Quando o acampamento está 
começando tem muito trabalho para organizar tudo, é muita gente, é muita família... É a disciplina. Tem que decidir o que vai fazer, para ninguém ficar à toa, zanzando no acampamento. Por exemplo uma pessoa vai plantar, outra pessoa vai tomar conta da segurança, tem que sair para resolver alguma coisa na rua, para ver a escola das crianças. Tem a ciranda para tomar conta das criancinhas pequenas do acampamento. Tudo em ordem. A coordenação logo cedo, organiza a pauta e é assim que a gente vive. Chega a tarde, as pessoas vão descansar cada qual na sua barraca, tomar seu banho e dormir. Outros vão tirar vigia, pois cada núcleo tira a sua vigia por noite. Isso é para segurança, porque a gente é muito visado. Então é muito perigoso. Está arriscado a tudo ali. Está dentro do que é nosso direito, mas ainda corremos risco de ter algum problema. Às vezes, à noite, tem alguém que vai ameaçar a gente. Tem noite que não tem sossego para dormir, vem alguém fazer gracinha, ameaçar a gente no acampamento. É um terror. Vida de acampamento não é fácil, em dia de frio, quando está muito frio a gente passa um sufoco.

Não temos luz elétrica lá. Água a gente tem porque quando a gente vai para um lugar que tem nascente preserva aquela água, não deixa sujeira ali, procura deixar limpinha para poder usar. Agora estamos numa área que tem muito eucalipto e isso está acabando com a mina. O fazendeiro plantou muito eucalipto, aí a gente cavou um poço. É de lá que está pegando água nos baldes para levar para o barraco, para tomar banho, para o banheiro...

O barraco é de lona preta, não tem outro jeito. Barraquinho de lona de chão. Só que a gente vai melhorando, vai dando uma ajeitadinha, bota tapete, para parecer uma casa, a nossa casa, lá eu moro mesmo.

Há poucos dias, uns dois dias antes da gente vir para cá, impedimos de sair um caminhão de eucalipto de lá. Era para a polícia impedir. Nós tivemos que impedir. Porque era clandestino. O fazendeiro vendeu, mas não tinha nota fiscal... Então eles vieram buscar o 
eucalipto e impedimos do eucalipto sair. Ficou naquela coisa, fechamos a rua e não deixamos sair, aí veio a polícia brigar com a gente, conversar que não podia fazer aquilo. A gente falou: "Se tiver nota fiscal pode sair já que é tudo dentro da lei, tem que ser na lei!". Foi então que o capanga da fazenda falou: "Tem nota fiscal, mas não está aqui. É vencida a nota fiscal." "Então traz a nota fiscal para gente ver!" Ele não trouxe a nota fiscal... Aí o policial enrolou, enrolou, e o caminhão teve que sair. Mas mesmo assim pedimos os nomes do policial e do capataz. A gente pediu uma ajuda para um advogado, Francisco Lima. Ele falou com o policial... Foi uma briga danada, não vamos deixar mais tirar eucalipto de lá, da próxima vez, nem com nota fiscal vai tirar mais madeira dali.

Está tudo errado! Começa pelo erro do eucalipto, não está certo plantar eucalipto perto da nascente, pois ele só faz sugar. Depois onde tem eucalipto não tem um pássaro... Eucalipto estraga tudo.

Participei de uma palestra do Movimento... sobre transgênicos... Curso ainda não fiz.

Tenho vontade de continuar estudando. E vou, porque o Movimento proporciona para todos direito à escola. O Movimento não só ajuda a pessoa a conquistar terra como a estudar. Além disso, dá trabalho também! Quando voltar para casa, ainda vou resgatar a minha educação. Com certeza!

Tudo que falei é de coração. É o que aconteceu comigo. Não foi com fulano ou com sicrano. Foi comigo! Foram fatos da minha vida! O que tenho para falar é isso aí... Mas não me canso de dizer que eu me sinto GENTE no Movimento. Me sinto uma pessoa importante. Aqui cada um de nós tem direito e oportunidade. Oportunidade de ser o que quer no Movimento. Tenho para falar que sou muito satisfeita com o Movimento. Agradeço muito ao MST, e aos companheiros também. Fico muito satisfeita de estar aqui, apesar do nosso sufoco, de levantar cedo, da friagem, de ficar doente resfriada, de ficar rouca, de tanto gritar... Me 
sinto feliz de estar aqui no meio do povo, dos companheiros. A gente se sente uma família, como eu estava dizendo.

Espero que o presidente faça alguma coisa, porque é o povo dele! Não é só o presidente que vai fazer, mas queremos que ele compreenda, que não estamos aqui à toa, que nos ajude. Que quando chegar lá em Brasília, que ele atenda o nosso pedido e resolva logo, para gente não ter que voltar aqui. Porque o povo já está cansado, não agüenta mais. Não sou só eu.

Que da próxima vez que a gente vier seja para agradecer... Queremos isso. Riqueza pro nosso país, não é riqueza para tirar daqui e botar para fora do país. A alimentação boa tem que ser na mesa dos brasileiros, sobrando, transporta para lá. Mas a prioridade é o Brasil. Se ele é brasileiro e é um presidente que honra a terra dele não pode mandar tudo que é nosso para fora. O povo brasileiro está morrendo à míngua, então ele que se mexa. Tenho esse recado para ele.

Nós estamos querendo uma vida digna para todos, não é só para os sem-terra, é para toda nação. Porque lá fora o povo está morrendo de guerra, de tiro. Mas a pior guerra é essa aqui nossa, a fome, a miséria, isso sim é uma guerra! Então ele tem que zelar pelo país dele.

Se ele falou: "sou presidente dessa nação". Tem que fazer alguma coisa, para a gente se orgulhar dele, o povo não está se orgulhando dele. Sou uma pessoa que não sei falar bonito, mas eu falo de coração! 


\section{Passo a passo do projeto}

Ao invés de tomar a palaura, gostaria de ser envolvido por ela e levado bem além de todo começo possivel.

Michel Foucault - A ordem do discurso

De onde começar? Essa é a pergunta que ocorre quando inicia-se algo. Penso que minha formação me fez treinar o olhar para enxergar as relações entre os fatos do passado e do presente e por isso a tendência é iniciar tudo no "Fiat Lux". Tentando evitar tal digressão, mas fazendo alguma, uma história desse projeto pode-se iniciar nos tempos de graduação quando comecei a fazer pesquisa. Sendo assim, esse é um momento também de balanço e reflexão de uma trajetória acadêmica junto aos dois principais temas de estudo que apresento nesse trabalho: a História Oral e o Movimento dos Trabalhadores Rurais Sem Terra.

O critério de organização geral do texto foi o cronológico, no entanto, em alguns pontos, o ir e vir do pensamento contesta essa lógica e subverte o texto. De forma geral, o que se apresenta é um entrelaçar de uma história de vida com uma história dos estudos na vida.

O estudo da história oral acompanhou, desde muito cedo, minha formação em história. No segundo semestre de graduação, nas aulas de Metodologia II, ministradas pelo professor José Carlos Sebe Bom Meihy, se deu o primeiro contato com essa forma de produção de conhecimento, que foi aprofundado ao começar a fazer parte de um grupo de estudos, ainda sem nome, mas que mais tarde seria batizado como Neho/USP, no qual fiz amigos que me acompanharam pelos quatro anos de faculdade e com os quais ainda hoje discuto questões referentes à história oral e à vida.

Assim, influenciada pelas amizades e por um professor sempre presente e provocador, fui envolvendo-me cada vez mais com a 
pesquisa. Desenvolvi um trabalho de iniciação científica sobre "história de vida de prisioneiros de guerra no Vale do Paraíba". ${ }^{7}$ Entrevistando imigrantes alemães pude entender temas da história recente do Brasil e do mundo como a Era Vargas, a República de Weimar, o Nazismo e a II Guerra Mundial, além de colocar em prática as leituras e discussões feitas acerca da história oral.

Foi nesse momento que encontrei uma possibilidade daquilo que, à época, pensei significar "fazer história". Sair às ruas, construir documentos, estar em contato com pessoas que participaram de momentos históricos importantes. Pessoas que fizeram história e que por sua vivência podiam contar o que tinha acontecido. Vejo, com os olhos de hoje, o quanto mudei em relação àquela prática inicial. Nesse sentido, compartilho do que Paul Thompson ponderou sobre sua própria experiência de pesquisa:

Nossos primeiros e, um tanto ingênuos, debates metodológicos e nosso entusiasmo pelos depoimentos acerca "do que realmente aconteceu" amadureceram, dando lugar a um entendimento comum das questões técnicas e humanas fundamentais de nossa profissão e o que é igualmente importante, a uma percepção muito mais apurada de como cada história de vida interliga inextricavelmente evidências tanto objetivas quanto subjetivas, que são diferentes, mas igualmente importantes. ${ }^{8}$

Nas reuniões periódicas no Neho, comecei a conhecer os debates teóricos sobre memória, narrativa e história oral. Em respeito a tais leituras, devo aqui fazer um adendo. Evidentemente, o texto apresentado aqui não é a reconstituição do que aconteceu, como aconteceu, mas a narrativa daquilo que lembro, reorganizada pela necessidade do hoje: a escritura de uma tese. Assim, da mesma forma que as histórias de vida que compõem esse trabalho, essa apresentação de linhas teóricas que me influenciaram é uma reconstrução de um passado, à luz do presente.

\footnotetext{
${ }^{7}$ Pesquisa desenvolvida com bolsa de pesquisa Fapesp de novembro de 1996 a novembro de 1997 e CNPq - Pibic março de 1998 a março de 1999.

${ }^{8}$ THOMSON, A., FRISCH, M. e HAMILTON, P. Os Debates sobre memória e história: alguns aspectos internacionais. IN: FERREIRA, M. M. e AMADO, J. Usos e abusos da história Oral. Rio de Janeiro: Editora FGV, 1996, p. 69, citando THOMPSON, P. em editorial Oral History, 1989.
} 
A vivência relatada nesse texto não é tão emocionante ou sedutora quanto às apresentadas pelos colaboradores dessa pesquisa, mas dá conta de explicar um caminho acadêmico percorrido. Caminho esse iniciado em diálogo com autores como Benjamin, Halbawchs e Pollak. ${ }^{9}$ Lembro-me da primeira vez que entrei em contato com eles. A estranheza que senti. Tudo neles me era alheio. Lê-los, no entanto, me impulsionava a desvendar um universo de conhecimento completamente diferente daquele com que tinha me deparado até então.

Ficaram-me algumas percepções desses autores. Em Benjamin, o pensamento de que a narrativa não está interessada em transmitir o "puro em si" da coisa narrada como uma informação ou um relatório. Que a narrativa mergulha na vida do narrador, mas não a descreve, ou melhor, seu objetivo não é informar sobre ela.

Assim definido, o narrador figura entre os mestres e os sábios. Ele sabe dar conselhos: não para alguns casos, como o provérbio, mas para muitos casos, como o sábio. Pois pode recorrer ao acervo de toda uma vida (uma vida que não inclui apenas a própria experiência, mas em grande parte a experiência alheia. O narrador assimila à sua substância mais intima aquilo que sabe por ouvir dizer). Seu dom é poder contar sua vida; sua dignidade é contá-la inteira. ${ }^{10}$

Cito "O Narrador" ciente das críticas que esse texto vem recebendo nos últimos tempos, em especial as leituras feitas por Agamben e por Sarlo que relacionam as análises de Benjamin com seu tempo. ${ }^{11}$ Mas qual texto não é atrelado ao tempo de sua escrita? E sem dúvida, as colocações de Benjamin foram tão fortes que permanecem como possibilidade de diálogo até o presente.

Das leituras iniciais ficou também a idéia defendida por Halbwachs, nos anos 20-30 do século XX, de que a memória devia ser entendida, sobretudo, como um fenômeno coletivo e social. Ou seja,

\footnotetext{
${ }^{9}$ BENJAMIN, W. O narrador. In: Obras escolhidas: magia e técnica, arte e política. São Paulo: Brasiliense, 1985; HALBAWCS, M. A memória coletiva. São Paulo: Vértice, 1990; POLLAK, M. Memória e identidade social. In: Estudos Históricos, Rio de Janeiro, vol. 5, ano 10, 1992, pp.200-212.

${ }^{10}$ BENJAMIN, W. Op. Cit., p.221.

${ }^{11}$ AGAMBEN, G. Infância e história: destruição da experiência e origem da história. Belo Horizonte: Editora UFMG, 2005 e SARLO, B. Tempo passado: cultura da memória e guinada subjetiva. São Paulo: Companhia das Letras, Belo Horizonte: Editora UFMG, 2007.
} 
como um fenômeno construído coletivamente e submetido a flutuações, transformações, mudanças constantes, contrariando a idéia de que a memória seria um fenômeno apenas individual, algo relativamente intimo, próprio da pessoa. Devo também destacar a leitura de Pollak, com críticas ao seu mestre e apresentação de novas "memórias". A respeito desses autores e seus estudos sobre memória, falarei mais detalhadamente no próximo capítulo desta tese.

De maneira geral, posso dizer que li esses textos, mas somente quando me deparei com essas questões empiricamente é que afinal fizeram sentido. A formação junto ao Neho possibilitou-me experimentar trabalho de campo e estudo teórico. Assim fui constituindo um diálogo entre os teóricos que lia e as entrevistas que fazia.

Uma prática em história oral foi se configurando e outras leituras surgiram. Evidentemente, tais leituras começaram a me colocar em contato com discussões distintas das que participava em sala de aula, nas disciplinas regulares do curso de história onde estavam presentes leituras relacionadas aos estudos das linhas de pensamento e de dimensões do campo histórico.

Nesse debate travado em nossas reuniões, destaco a contribuição dos textos de Portelli12 e de Zeldin ${ }^{13}$. Esses me mostraram uma outra história possivel. Uma história de sonhos e de sentimentos. Portelli, por exemplo, priorizou ver na lógica e no entendimento dos argumentos do entrevistado, uma verdade. Não a verdade universal, mas uma, que dá sentido e justifica opções e caminhos de uma trajetória de vida.

Alessandro Portelli afirma suscintamente que: "the fact that a culture is made up of individuals different from on another is one of the

\footnotetext{
${ }^{12}$ PORTELLI, A. Sonhos ucrônicos: memórias e possíveis mundos dos trabalhadores. IN: Projeto história. Revista do programa de Estudos Pós-Graduados em história e do departamento de história da PUC/SP. São Paulo: EDUC, n. 10, dez 1993, pp. 41-58.

${ }^{13}$ ZELDIN, T. Uma história íntima da humanidade. Rio de Janeiro/São Paulo: Ed. Record, 1996.
} 
important things that social sciences sometimes forget, and of which oral history reminds us."14

Esses textos foram marcantes na medida em que fizeram entender a importância do conceito de alteridade, caro à antropologia, com o qual tinha tomado contato por meio da leitura de Todorov ${ }^{15}$ e Rosaldo ${ }^{16}$.

Embasada por essas leituras e discussões, pude me posicionar frente a uma prática de pesquisa. Tais textos marcaram minha experiência de estudante e plantaram muitas dúvidas na mente da menina que pensava encontrar respostas na universidade.

$\mathrm{Na}$ crise de paradigmas vivida nos anos de 1990, mesmo a universidade buscava respostas. Eram tempos de muitas mudanças e alguns chegavam a decretar o "Fim da História". 17 Foi necessário trazer à tona um sentido ao fazer histórico. Pensar no "quem" escrevia a história e "para quem" a história era escrita. Em meio a isso, a história oral se apresentara encantadora, proporcionando um contato direto com pessoas e com temas da história contemporânea.

\section{Um início para essa pesquisa}

Nesse contexto, envolvida pelo fazer da história oral, pouco antes de me formar, em 1997, abracei a idéia de realizar um estudo sobre a Marcha Nacional por Reforma Agrária Emprego e Justiça, organizada pelo MST - Movimento dos Trabalhadores Rurais Sem Terra. Nesses tempos, Andrea Paula dos Santos ${ }^{18}$ e eu fomos a Brasília entrevistar 16 pessoas, membros do Movimento, que se encontravam

\footnotetext{
${ }^{14}$ PORTELLLI, A. The death of Luigi Trastulli and other stories. Albany: State University of New York Press, 1991, p. 118.

${ }^{15}$ TODOROV, T. Nós e os outros: a reflexão francesa sobre a diversidade humana. Rio de Janeiro: Jorge Zahar, 1993.

${ }^{16}$ ROSALDO, R. Culture and Truth: the ranking of social analisys. Boston: Beacon Press, 1989.

${ }^{17}$ Tese defendida por Francis Fukuyama pela primeira vez em um artigo publicado em 1989, intitulado: The end of History? (disponível em http://www.wesjones.com/eoh.htm, acessado em 06/05/07), e estendida no livro: FUKUYAMA, F. The End of History and the Last Man. New York: Free Press, 1992.

${ }^{18}$ Cabe dizer que esse foi o primeiro de uma série de trabalhos que fiz junto com Andrea. O corpo documental do presente trabalho foi constituído em parceria com esta pesquisadora, possibilitando a gravação de 47 entrevistas.
} 
em diferentes estágios da luta pela terra, vindas dos diferentes estados brasileiros representados no acampamento nacional, em Brasília.

Um ano depois, em 1998, a publicação do livro "Vozes da marcha pela terra"19 e a aprovação para a seleção do mestrado foram grandes presentes de formatura. Motivada e envolvida, elegi o MST como tema de estudo. Fiz uma pesquisa de mestrado sobre uma família em um assentamento do MST, que resultou na dissertação intitulada "Processos de mudança no MST: história de uma família cooperada". ${ }^{20}$ Nesse trabalho pude perceber a riqueza e a potencialidade do uso da história oral, principalmente no que se refere à possibilidade de ter acesso ao que há de íntimo em uma comunidade e de subjetivo no sujeito histórico. "Estar lá"21 fez toda a diferença. Segundo Geertz:

O que o etnógrafo propriamente dito deve fazer, propriamente, é ir a lugares, voltar de lá com informações sobre como as pessoas vivem e tornar essas informações disponiveis à comunidade especializada, de uma forma prática, em vez de ficar vadiando por bibliotecas, refletindo sobre questões literárias. ${ }^{22}$

Muito irreverente, a leitura de Geertz marcou minha formação, de modo a sempre valorizar as experiências de campo, mesmo não sendo eu uma etnógrafa. O estar lá trouxe conseqüências para o estar aqui ${ }^{23}$, dentro da academia e das bibliotecas. Esse fazer, na história e na antropologia, é muito próximo, pois ambas trabalham com os mesmos elementos para dar conta de "representar" o que foi estudado. Tanto a história oral quanto a etnografia fazem uso da escrita para sistematizar o conhecimento produzido por suas pesquisas.

\footnotetext{
${ }^{19}$ RIBEIRO, S. L. S., MEIHY, J. C. S. B. e SANTOS, A. P. dos. Vozes da marcha pela terra. São Paulo: Loyola, 1998. Resultado do trabalho do Núcleo de Estudos em História Oral -Neho. 20 Pesquisa resultante do projeto: “O dia-a-dia de uma luta: história de vida de famílias no MST”, desenvolvido com o apoio da Coordenação de Aperfeiçoamento de Pessoal de Nível Superior - Capes, no Departamento de história - FFLCH - Universidade de São Paulo - USP, no período de março de 1999 a março de 2001.

21 Conceito trabalhado por Geertz em vários de seus textos, ao defender a importância do trabalho de campo e por Foucault ao falar da participação de intelectuais na vida política. Reflexões presentes em: GROSS, F. Op. Cit.

22 GEERTZ, C. Obras e vidas: o antropólogo como autor. Rio de Janeiro: Ed. UFRJ, 2002, p.11. 23 Conceitos trabalhados nos textos "Estar lá: a antropologia e o cenário da escrita” e "Estar aqui: de quem é a vida, afinal?” em que Geertz fala sobre as dificuldades de escrever um texto etnográfico. São respectivamente o primeiro e o último capítulo de GEERTZ, C. Op. Cit. 2002, pp. 11-40 e pp. 169-193.
} 
Em meio à elaboração da dissertação, o envolvimento com os assentados possibilitou a feitura de um $\mathrm{CD}$ de músicas caipiras, gravadas com cantadores locais. ${ }^{24}$ Em 2002, no dia em que estava apresentando os resultados acadêmicos de minha pesquisa, muitos amigos do Neho e dois membros da família Ramos ${ }^{25}$ também estiveram lá.

Paralelamente à finalização do Mestrado, nos anos de 2001 a 2003, foi realizado um trabalho de pesquisa, de um convênio firmado entre a Universidade de São Paulo e a Fundação Itesp - Instituto de Terras do Estado de São Paulo. Fiz parte de uma equipe de quatro pesquisadores, e pude conhecer nove assentamentos do estado e ter contato com inúmeros assentados. Nesse processo, foram registradas 86 histórias de vida. Esse trabalho resultou na publicação do livro: Vozes da Terra: histórias de vida dos assentados rurais de São Paulo. ${ }^{26}$

Dando continuidade aos trabalhos de história oral junto aos moradores do campo, fui convidada pelo MST para realizar parte de uma pesquisa, financiada pelo Unicef - Fundo das Nações Unidas para a Infância, sobre alternativas para a escolarização de adolescentes do campo, que envolveu a realização de cinco entrevistas e resultou na publicação de dois artigos. ${ }^{27}$ Este trabalho se desdobrou em outro projeto, também realizado em parceria com o Unicef, que foi desenvolvido no ano de 2004 e do qual fui coordenadora nacional. Esta segunda pesquisa organizou-se em 18 estados, visando à elaboração de políticas públicas de educação para o campo além das ações de

\footnotetext{
24 Projeto desenvolvido em conjunto com Rodrigo Garcez e Andrea Paula dos Santos que resultou na elaboração do CD “Movimento no ar”. A seleção das músicas e uma exposição de fotos foi parte do trabalho de conclusão de curso do Departamento de Cinema, Rádio e Televisão da ECA-USP de Rodrigo Garcez e de meu trabalho de pesquisa junto à comunidade. O CD foi gravado no estúdio da Rádio Camponesa e lançado em uma noite de festa, no galpão da comunidade, durante a Semana Olímpica, em maio de 2001. Nele há 21 composições de sete cantadores do assentamento.

${ }^{25}$ Durante o mestrado os membros da família Ramos foram colaboradores da pesquisa, depois disso se tornaram amigos da pesquisadora.

${ }^{26}$ RIBEIRO, S., IOKOI, Z., ANDRADE, M. e REZENDE, S. Vozes da terra: histórias de vida dos assentados rurais de São Paulo. São Paulo: Fundação ITESP/ Imprensa Oficial, 2005.

${ }^{27}$ Artigos intitulados respectivamente de "Engenheiro Maia: o dia-a dia de conquistas de uma escola” e “Adolescentes: sujeitos da escolarização”, ambos publicados em: MST. Alternativas de escolarização dos adolescentes em assentamentos e acampamentos do MST. Coleção cadernos Iterra, Ano III, $\mathrm{n}^{\circ}$ 8, novembro de 2003.
} 
mobilização e de inclusão de cinco mil adolescentes nas escolas públicas.

Nessas várias oportunidades em que pude trabalhar com o Movimento, notei como a questão da identidade servia sempre como reforço para um discurso de luta e ao mesmo tempo era transformada pelas estratégias empregadas pelos novos sujeitos formados pelo próprio processo dessa luta.

As mudanças são constantes e fazem parte da própria concepção de movimento social adotada pelo MST, que é visto por seus membros como "Movimento em movimento". Isto se reforça se forem consideradas as transições que estão sendo enfrentadas, como, por exemplo, da condição do lavrador quanto à posse da terra, dos padrões de relações familiares e da forma de trabalho e produção no lote, ${ }^{28}$ dentre outras.

Como esse é um movimento que marcha, achei que seria importante acompanhá-lo em uma de suas grandes manifestações. A Marcha Nacional de 2005 foi, portanto, campo escolhido para, caminhando, tentar entendê-lo melhor.

\section{Trabalho de campo em marcha}

Partiu-se para o trabalho de campo, com um conjunto de referências prévias. Todavia destaca-se a importância de "estar lá" para a história oral, mas também para o estudo de um movimento social em marcha. Evidentemente, fazer um trabalho de campo não é a única maneira de fazer o registro das histórias, mas somar a isso um envolvimento etnográfico com as pessoas que se propõe conhecer, foi o que possibilitou esse trabalho ser o que é. Dessa forma, para esse

\footnotetext{
${ }^{28}$ Essas foram as principais mudanças que percebi em meu trabalho de mestrado. RIBEIRO, S. L. S. Processos de mudança no MST: história de uma família cooperada. São Paulo, Dissertação de Mestrado DH/FFLCH, 2002, p. 206.
} 
estudo, assim como para a antropologia, a “observação participante"29 foi um ponto de referência que se desdobrou em novas práticas de pesquisa de campo. Que já se sabe bastante complexa, como afirma Geertz:

Em antropologia ou, de qualquer forma, em antropologia social, o que os praticantes fazem é etnografia (...). Segundo a opinião dos livros-textos, praticar a etnografia é estabelecer relações, selecionar informantes, transcrever textos, levantar genealogias, mapear campos, manter um diário, e assim por diante. ${ }^{30}$

Toda essa prática em nada simplificou a escritura do texto dessa tese, pelo contrário, pois se o trabalho de campo ajudou, deve-se também refletir a respeito de seus significados e descrevê-los. Soma-se a essa tarefa contar sobre meu envolvimento como mediadora e pesquisadora do MST. Formas de desenvolver esse trabalho de campo e de descrever o envolvimento com o grupo que se pesquisa são objeto de estudo de muitos trabalhos de antropologia. Dessas discussões constatou-se que não há nada simples em uma descrição de trabalho de campo, e talvez por sua complexidade Geertz a tenha chamado de “densa".

Mas não são essas coisas, as técnicas e os processos determinados, que definem o empreendimento. O que define é o tipo de esforço intelectual que ele representa: um risco elaborado para uma "descrição densa", tomando emprestada uma noção de Gilbert Ryle. ${ }^{31}$

Densas também são as discussões que envolvem a prática de elaborar um texto que conte o que foi pesquisado. Vale lembrar que para dar conta de tais desafios, muitos antropólogos vêm trabalhando com a idéia da impossibilidade de reproduzir toda uma experiência de

\footnotetext{
${ }^{29}$ A observação participante, definida principalmente pelo antropólogo Bronislaw Malinowski como a convivência íntima e prolongada do pesquisador com seus 'informantes nativos', ao refutar a 'antropologia de gabinete', permitiu um determinado tipo de relação na qual o entrevistado se coloca como um instrumento de pesquisa, propiciando à antropologia a perspectiva intersticial (o olhar de dentro) que é a sua tarefa básica, sua marca registrada, desde então. Reflexões presentes em: SILVA, V. G. da. O antropólogo e sua magia: trabalho de campo e texto etnográfico nas pesquisas antropológicas sobre religiões afro-brasileiras. São Paulo: EDUSP, 2006, p.13.

${ }^{30}$ GEERTZ, C. A interpretação das culturas. Rio de Janeiro, Zahar Editores, 1989, p.15.

${ }^{31}$ Idem, ibidem.
} 
campo num relato etnográfico. ${ }^{32}$ Paralelamente, não é pequena a produção historiográfica que aponta a inviabilidade de se reconstruir o passado, como ele foi.33 Aqui, portanto, apresento uma descrição a partir da experiência de pesquisa filtrada pelas contingências do trabalho e dos prazos acadêmicos.

A marcha foi escolhida como "campo" para essa pesquisa, pois a atuação do MST é nacional e se intencionava um registro da identidade pensada na ação concretizada em todo país, ao mesmo tempo em que se concretiza em âmbito regional. Para não anular o diálogo estabelecido entre nacional e regional, foi preciso escolher uma situação em que ambos estivessem presentes.

$\mathrm{Na}$ marcha era possivel ter acesso a essa grande diversidade. Durante o trabalho de campo tive o prazer de ser acompanhada por Andrea Paula dos Santos, que me ajudou na tarefa de registrar parte das entrevistas. Quero marcar aqui que essa ajuda foi fundamental, dado o grande número de pessoas e o pequeno tempo de que se dispunha para realizar as entrevistas.

Os narradores eram originários dos 23 estados representados, nos quais o MST está organizado. Registraram-se tramas biográficas de diferentes sem-terra. Entrevistaram-se lideranças nacionais e regionais, assentados e acampados, homens e mulheres. No total foram 47 entrevistas.

De maneira geral, foram entrevistadas duas pessoas, para dar atenção à questào de gênero, dos 16 estados que participaram da marcha de 1997, sobre a qual foi feito um trabalho anterior. E uma pessoa de cada um dos sete estados onde o MST se organizou mais recentemente, sendo previstas 39 entrevistas no total. No entanto, em algumas situações, as pessoas subverteram a lógica proposta pela pesquisa, indicando mais de um ou de dois entrevistados, para cobrir o que tinham selecionado como boas histórias ou ainda para que se

\footnotetext{
${ }^{32}$ Dentre alguns trabalhos destaco o de Vagner Gonçalves da Silva. O antropólogo e sua magia (Op. Cit).

33 Muitos são os exemplos que podemos citar, dentre eles: o livro WHITE, H. Metahistória. A imaginação histórica no século XIX. São Paulo: EDUSP, 1992; os balanços de BURKE, P. Op. Cit. 1992; História e teoria social. São Paulo, Editora UNESP, 2002; e mais recentemente JENKINS, K. Op. Cit.
} 
sentissem plenamente representados. Dessa forma, sempre que possivel, foram atendidas as indicações e pedidos das coordenações estaduais.

Ninguém teve papel secundário nessa história, e como não se trata da história dos "vencedores" ou da elite, é aplicável o termo história "vista de baixo". O que se almeja é compreender a construção da identidade do Movimento à luz de suas experiências e de relações e reações geradas por essas experiências. Nesse sentido, o conceito de representatividade ganhou novos contornos frente às possibilidades da história oral.

As entrevistas selecionadas para compor a tese não são um conjunto estatisticamente representativo, frente aos cerca de doze mil marchantes. Elas foram escolhidas do total das 47 entrevistas realizadas posto que mostram um pouco da diversidade regional do país, ao mesmo tempo em que apresentam pessoas de diferentes gerações. Além disso, houve a preocupação em disponibilizar narrativas de mulheres e de homens, respeitando a proporcionalidade desses em relação à participação na marcha. Mesmo com essas explicações, é bom que se diga que outras oito histórias de vida poderiam ter sido selecionadas. Então, por que essas e não outras? Essa resposta tem caráter bastante subjetivo. Vale colocar em destaque que essas foram as narrativas que mais trouxeram elementos para o estudo sobre identidade e que mais profundamente me marcaram enquanto pesquisadora.

Foi fundamental que as fontes para este estudo fossem produzidas por e com os sujeitos dessa história de transformação, ou seja, os próprios membros do Movimento. Pois quem melhor que eles pode responder quais identidades dos sem-terra estão sendo gestadas?

Com isso, a história oral ganhou relevância no desenvolvimento desse projeto de pesquisa. Evidentemente, estou firmando minha opção por uma história subjetiva, que não busca uma verdade e que dialoga com a idéia de que "nossas mentes não refletem diretamente a realidade. Só percebemos o mundo através de 
convenções, esquemas e estereótipos, um entrelaçamento que varia de uma cultura para outra".34 Lembrando sempre que a opção pela história oral nos conduz a uma interpretação que parta das entrevistas e dialogue com outras preocupações, num movimento "de dentro" para "fora".

Procurando essa interação com os "de dentro", em fevereiro de 2005, encontrei-me com Roseli Caldart, uma das coordenadoras do setor de educação do Movimento, no Instituto de Educação Josué de Castro, no município de Veranópolis - RS. Nessa conversa, foram definidos os rumos mais gerais dessa pesquisa e como ela iria dialogar com a experiência acumulada de dez anos acompanhando a vida de assentados e acampados e observando os passos desse que é o maior movimento social do Brasil, na atualidade. ${ }^{35}$

O envolvimento como pesquisadora, mas também como parceira do Movimento em vários projetos, pode ser considerado por alguns algo limitador para os olhos do pesquisador. No entanto, é preciso pontuar dois aspectos: primeiro, provavelmente essa comunidade não se abriria para esse trabalho não fosse a existência de um envolvimento; segundo, esse é um dilema comum vivido por vários pesquisadores que, como eu, se envolveram em movimentos políticos e sociais. Sobre isso, Christine Chaves afirmou:

“...os desafios da pesquisa eram melhor conhecidos, particularmente a dificil tarefa de equacionar a paixão, no misto de sentimentos contraditórios que ela abriga, com o equilíbrio e isenção necessários ao empreendimento intelectual." 36

Contada a história do delineamento do projeto, parto para uma descrição de como ocorreu o meu trabalho em campo. Lembrando

\footnotetext{
${ }^{34}$ BURKE, P. Abertura: a nova história, seu passado e seu futuro. IN: BURKE, P. (org) Op. Cit. 1992, p.15.

${ }^{35}$ Todos os dados sobre o MST são aproximados, pois como seu próprio nome diz, as pessoas que dele participam estão em movimento: acampamentos são formados todos os dias e na demora da espera por terra, muitos desistem de esperar. De qualquer forma, pode-se estimar que, no Brasil todo, são aproximadamente 350 mil famílias de assentados e mais 116.382 famílias de acampados em 632 acampamentos por todo o país (www.mst.org.br - 10/10/2004).

${ }^{36}$ CHAVES, C. de A. A marcha nacional dos sem-terra: um estudo sobre a fabricação do social. Rio de Janeiro: Relume-Dumará, 2000, p. 26.
} 
que ao fazer esse balanço sobre o trabalho realizado e posteriormente apontar críticas e limites da pesquisa, é importante lembrar das reflexões de Gros, sobre a obra de Foucault, que serve como modelo e exemplo a ser alcançado:

Não existe um discurso verdadeiro de um lado, neutro e pálido, e, do outro, uma coragem em busca de causas a defender. Como em Spinoza: uma só substância, isto é, uma só força. Foucault não é filósofo e militante, erudito e resistente. Ele é historiador porque militante, e resistente porque erudito. Para nossos morosos tempos, que organizaram a grande divisão entre os doutos isolados na espiral de suas especialidades, tornados inaudiveis pela força do rigor e da probidade, e os agentes sociais portadores de discursos ocos e vazios pela força de querer ser ouvidos, é importante lembrar que o saber histórico, com suas exigências próprias, e o engajamento político, com seus riscos, puderam um dia se enriquecer, alimentar-se mutuamente. ${ }^{37}$

Foi muito diferente minha presença nessa marcha, se comparada com a vivência que tive na primeira marcha, em 1997, da qual participei apenas no final, no acampamento já em Brasília. Tive condições de estar presente desde o cadastramento e assim encontrar pessoas de diferentes lugares, que fui conhecendo nesses anos de trabalho junto ao Movimento. Naquela primeira situação, me senti bem vinda. A coordenação, naquela época, foi agradável e receptiva. Em toda minha vivência com o MST me senti acolhida. Mas, sem dúvida, é diferente sentir-se acolhida e ter a oportunidade de rever amigos. Companheiros de idéias.

$\underline{\text { Atos de estréia }}$

Marchar é mais do que andar É traçar com os passos roteiro que nos leva à dignidade sem lamentos. Marchar e vencer - Ademar Bogo

Todos os participantes começaram a chegar em Goiânia no dia

\footnotetext{
${ }^{37}$ GROS, F. A coragem da verdade. In: GROS, F. (org). Op. Cit., p. 12.
} 
27 de abril. Cheguei dia 28, quando oficialmente iniciava-se o cadastramento. Foram três dias para que todos estivessem prontos para marchar. Enquanto isso, cerca de oito mil pessoas se acomodavam no Estádio Serra Dourada. A presença de muitos estrangeiros podia ser notada. Um casal de turcos dormia ao meu lado, e eu mesma estava acompanhada de um amigo vindo da Itália para participar do início da marcha.

Logo que cheguei, encontrei Rosana, liderança do estado de Goiás, responsável pela organização. Ela me colocou em contato com a equipe responsável pelo cadastramento e pude trabalhar nisso naqueles três primeiros dias. Foi um acaso, mas, de certa forma, assumi uma posição estratégica, pois pude estar em contato com muitas pessoas, explicando e entendendo como tudo ia acontecer.

Por serem muitas pessoas, o cadastramento foi feito da seguinte maneira: todos os ônibus que chegava tinham um coordenador que se encaminhava ao ginásio com uma lista contendo os nomes de todos os viajantes, a região do estado de origem e o movimento social a que pertenciam - algumas pessoas não eram do Movimento e estavam ali para dar seu apoio. Então, era liberado o número de crachás e mochilas para que o coordenador entregasse para seu grupo.

Cada marchante recebeu um crachá de identificação no qual colocava o nome dele, o estado a que pertencia, o núcleo de base em que estava e a equipe que ia trabalhar durante a marcha. ${ }^{38}$

Além do crachá, cada marchante recebeu também uma mochila, com uma caneta e um livro, um caderno e uma publicação pequena intitulada o "Manual do marchante" com textos de lideranças do Movimento e uma capa de chuva, que não foi usada, já que não choveu em nenhum dia da marcha. Algumas mochilas receberam cartilhas.

Naquele momento, o que observei foi o respeito e a importância dada aos livros. Algumas vezes as pessoas vinham

\footnotetext{
${ }^{38}$ Equipes de trabalho eram os grupos de pessoas designados para as tarefas de limpeza, cozinha, segurança, mística etc. Essas equipes foram decididas na assembléia geral do dia 30 de abril.
} 
reclamar uma troca, dizendo: "na mochila de fulano veio um livro mais grosso." Havia também os que diziam: "eu e meu colega recebemos o mesmo livro. Posso trocar um deles?”, numa evidência de potencial intercâmbio. Infelizmente, na maioria dos casos, nossa resposta foi negativa, pois seria um trabalho imenso atender a todos que buscavam trocar os livros. Tentávamos incentivar para que eles mesmos procurassem alguém que tivesse interesse em trocar o livro. $\mathrm{E}$ aos outros lembrávamos das vantagens do livro mais fino, à medida que iriam caminhar carregando menos peso...

Também naqueles dias foi possivel perceber algumas situações que iriamos viver adiante. Eram muitas pessoas, cerca de 8.000 cadastradas até o final do último dia em Goiânia - outras milhares chegaram durante a marcha -, e eram apenas dois banheiros femininos e dois masculinos no ginásio. Em um dos banheiros havia cinco chuveiros e no outro apenas três.

Sobre isso, cheguei a escrever em meu caderno de campo:

Ao tomar banho na frente de muitas outras mulheres, me vi despida de meus diferenciais, ali não havia distinções sociais. Éramos todas mulheres, encarando a água fria e pouca dos únicos cinco chuveiros disponíveis. Não havia tempo para "frescuras", todas ajudavam a segurar as roupas, para que não caíssem no chão e se encharcassem. Foi então que, enquanto aguardava minha vez ouvi Lurdes, com seu sotaque espanhol, falar: "é bom ir se acostumando, pois vão ter dias que teremos que dormir sem banho". Tive que concordar e com isso fui obrigada a pensar na força dessas mulheres que com seus filhos e filhas marchavam.

Durante a noite, fazia bastante frio, pois o vento circulava por dentro do ginásio. Todos tinham colchonetes, mas poucos tinham cobertas. O pessoal que chegou primeiro ficou no ginásio e depois, quem foi chegando, foi para o estádio que, por não ser fechado, era ainda mais frio.

Nesse trabalho, estou me propondo a ver a marcha como um momento de mística e é sempre difícil explicar o que é a mística. Essa tentativa por vezes parece até contraditória, pois como se explica o mistério? O mistério de estar na presença da inexplicável felicidade, 
constante cantoria e da alegria da dessas pessoas. Lá esse mistério parecia ser tão fácil de decifrar, pois ele era concreto. De uma maneira bastante geral e pouco precisa, não é falso, embora insuficiente, afirmar que mística para o MST é um momento de reflexão promovido por uma encenação, uma música, uma poesia... De qualquer forma, o comum a esses momentos é a emoção, tanto melhor a mística, quanto mais sensibilizadora ela for. E a marcha colecionou momentos de muita sensibilização.

“A luta é para valer!" A todo instante, podia-se ouvir os gritos de guerra que se destacavam em meio ao fundo musical de canções da tradição popular brasileira ou do repertório dos cantadores do Movimento, como as do cantor e compositor Zé Pinto.

Essa é uma luta bonita, alegre. Nada tem em comum com a imagem sisuda ou mal-humorada da esquerda que se fixou na cabeça de alguns. Pandeiros, violões, chapéus, foices e enxadas fazem parte desse cenário. O ginásio Serra Dourada aos poucos foi se enchendo de gente, barulho, músicas, colchonetes, bandeiras, malas, danças.

Tudo parecia muito ITINERÁRIO DA MARCHA NACIONAL descontraído. No entanto, existia uma organização bastante precisa. O itinerário da marcha estava prédefinido e estampava o verso dos crachás que todos os participantes receberam no cadastramento. Tinha-se tudo planejado, dia a dia, parada por parada, incluindo os quilômetros previstos de caminhada, até que se chegassem ao local de acampamento. PELA REFORMA AGRÁRIA

\begin{tabular}{|c|c|c|}
\hline DATA & KM A A PERCORRER & LOCAIS PARA ACANTPAR \\
\hline 300405 & Sühudo-Chegada das delezazaçes & Essádo Serra Dourada-Goiânia \\
\hline olestes & $\begin{array}{l}\text { Marcha até o centro de Gioiannia } \\
\text { para o Ato Politico } 8 \mathrm{~km} \text { (ida e } \\
\text { volta) }\end{array}$ & Wern \\
\hline 2 & $16,5 \mathrm{~km}$ & Antena gróximo ao ponto da PRF \\
\hline 3 & $19 \mathrm{~km}$ & Posto astes de Anipolis \\
\hline 4 & $14 \mathrm{~km}$ & Autódrowo - Anäpolis \\
\hline$s$ & 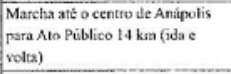 & Idem \\
\hline 6 & $21 \mathrm{~km}$ & $\begin{array}{l}\text { Pésimimo a AMBEV (frabrica de } \\
\text { erveja) }\end{array}$ \\
\hline 7 & $19 \mathrm{~km}$ & Cidade de Abadiśria \\
\hline 8 & $15 \mathrm{~km}$ & Ponte Abadiânis \\
\hline 9 & $12 \mathrm{~km}$ & Fspaco Aberto - Lanchoncte \\
\hline 10 & $14 \mathrm{~km}$ & Sehinkariol (Fistrrica de cerveja) \\
\hline 11 & $16 \mathrm{~km}$ & 7 Curvas \\
\hline 12 & Marcha parada & Lem \\
\hline 13 & $17 \mathrm{~km}$ & Cassu do intio \\
\hline 14 & $13 \mathrm{~km}$ & Próximo a Embrapa \\
\hline 15 & $17 \mathrm{~km}$ & $\begin{array}{l}\text { Residéncia Oficial do Govemo } \\
\text { (Taguatinga) }\end{array}$ \\
\hline 16 & $18 \mathrm{~km}$ & Parque da Cidasle \\
\hline 17 & $\begin{array}{l}\text { Marcha Fsplanada dos Ministenos } \\
\text { A to Püblico }\end{array}$ & \\
\hline
\end{tabular}

As coisas não precisam ser ditas, eram feitas com base na prática que essas pessoas adquiriram participando de outras manifestações. Da mesma forma, novas gerações vão aprendendo para os próximos eventos. 
A cena de um coordenador lendo o livreto do "marchante" se repetia. A leitura não foi uma tarefa delegada pelos organizadores da marcha. Tudo que foi feito foi entregar os crachás para serem preenchidos e as mochilas para serem distribuídas. No entanto, os coordenadores de cada grupo organizaram o preenchimento, a distribuição e a leitura do material contido dentro das mochilas.

Reuniões eram feitas a todo instante, pois ainda havia muito por ser decidido. E, segundo um dos coordenadores da marcha: "nunca se sai de uma reunião com menos tarefas do que se tinha ao entrar". Coordenadores dos ônibus, das brigadas, dos estados, se reuniam, discutiam, decidiam o que deveria ser feito. E, na seqüência, sentavam em seus colchonetes e batiam papo com seus amigos.

Havia muitos namoros acontecendo. E, segundo uma das meninas que dormiam ao meu lado: "nesse mundo dá tempo para tudo, trabalho e lazer. Só o que fica um pouco sacrificado é o descanso".

No dia $1^{\circ}$ de maio, a primeira atividade envolvia a todos: era uma assembléia geral, momento de dar unidade ao grupo que começava a se formar. A assembléia, realizada no ginásio na presença de todos, foi dirigida por lideranças do Movimento, em especial Ademar Bogo. Nela, foi definido que nos dias seguintes todos acordariam às $5 \mathrm{~h}$ da manhã, tomariam o café e arrumariam as coisas até as $7 \mathrm{~h}$, quando começariam a marchar. Das $15 \mathrm{~h}$ até as $17 \mathrm{~h}$ seria o horário destinado ao estudo. Até as $18 \mathrm{~h}$ todos teriam jantado e, a partir disso, estariam livres.

Também ficou acertado que cada dia um estado diferente puxaria a marcha e que Goiás, por ser o estado anfitrião, iniciaria a jornada no dia seguinte. Foram anunciadas também as doações de 60 mil marmitex pela prefeitura de Goiânia e de uma verba de 130 mil reais do Estado de Goiás, para a compra de carnes e verduras. A todo momento, era enfatizado o dever de cada marchante cuidar de sua vida e de seu corpo. Ademar Bogo falou por alguns minutos sobre o significado da marcha como oportunidade de aprendizado conjunto e possibilidade da criação de seres humanos novos, com valores 
diferentes.

A marcha, defendia Bogo, era uma obra coletiva, braços, pernas, cabeças de pessoas de diferentes forças e tamanhos. Dizia que era um grande encontro de gerações, de militantes, de objetivos, pois a reforma agrária precisava ser feita. Mas também um encontro de experiências de marchas que aconteciam cotidianamente nos estados que, mesmo pequenas, acumularam o conhecimento para realização daquela grande.

A marcha era também resultado da ação de dirigentes que acreditaram no sonho e há 20 anos plantaram a semente dessa árvore, "hoje frondosa, que é o Movimento". Por isso mesmo, apontou que a marcha não começava naquele dia e falou das dificuldades materiais e sentimentais que envolveram o processo de preparação daquela grande manifestação.

Por fim, Bogo apontou que o maior dos valores da marcha deveria ser a gentileza e, dando exemplos concretos, falava em dividir os pesos, em ajudar a agüentar a caminhada, em cuidar do outro, em pedir desculpas... Enfatizava que todos os marchantes deveriam ser solidários, respeitar a disciplina e ter consciência da importância do que estavam construindo. Sua fala finalizou com a citação de um poema em que se dizia: "somos guerreiros / guerrilheiros de um novo tempo". E completou: "você é a pessoa mais importante, pois sem isso não há marcha, luta ou história”.

Nesse mesmo dia, no início da tarde, todos saíram em marcha do Serra Dourada até o centro de Goiânia, onde aconteceu um ato público. O prefeito Íris Resende estava lá, junto com outros políticos, fazendo seus discursos. Houve apresentação de danças folclóricas e de teatro. Estar lá no $1^{\circ}$ de maio foi importante para a pesquisa e para a pesquisadora.

Não só pela data, mas porque vi aquele grupo começando a se formar, a se unir. Estavam todos felizes. Era possível ver a esperança. $\mathrm{Na}$ volta ao estádio todos voltaram marchando e cantando. Alguns dançavam forró, pois havia um trio elétrico tocando músicas. Todos 
estavam alegres começando aquela jornada. Ao chegar estádio já era noite e, depois da fila do banho, todos dormiram.

O dia 2 de maio, não foi comum. Começou muito antes das 5h40, quando um sol não muito forte apareceu no horizonte. Já às $4 \mathrm{~h}$, marchantes excitados assobiavam no ginásio; às 4h30, pediam por luzes acesas. Todos acordaram antes do horário combinado. Alguns não dormiram, mas os que dormiram acordaram muito mais cedo que o restante dos moradores da cidade. Às $6 \mathrm{~h}$ já era possivel ver a bagagem das pessoas empilhadas por estado, para que os caminhões de apoio

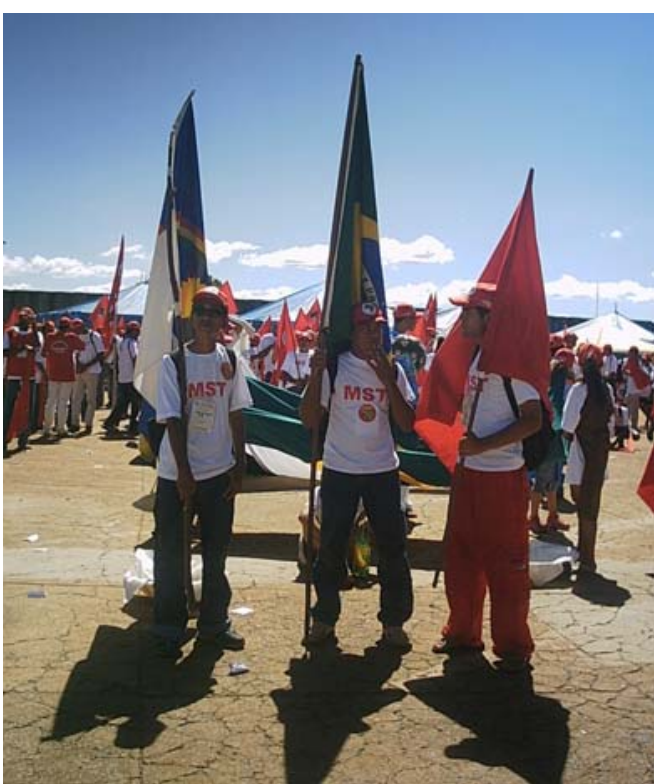

O estado que marchava à frente carregava sua bandeira e as do Brasil e do Movimento. levassem até o local do acampamento. Os primeiros a se aprontar foram os goianos. Colocaram-se à frente, puxando a marcha.

Cerca de oito mil pessoas se reuniram no estacionamento em frente ao estádio de futebol, para celebrar com um pastor o grande feito que estavam realizando. O hino do Movimento foi cantado ao som daquelas milhares de vozes. Ademar Bogo leu uma poesia e fez com que todos tirassem os sapatos, colocassem os pés no chão. O sonho se tornava tão concreto que era possível senti-lo pelo tato, audição, visão, olfato e até mesmo paladar.

Demorou um pouco, mais pela ansiedade que pelo tempo, e os 23 estados começaram a sair. Três fileiras, estado após estado, formavam a marcha. Todos antes de pegar a estrada, curvavam-se e 
passavam sob uma grande bandeira do MST.

O trânsito foi parado e, certamente, muitos ainda sonolentos, não entenderam o que acontecia. Os sem-terra enchiam as estradas "até onde a vista alcançava".

Algumas pessoas batiam palmas, sorriam. Outras olhavam atentas e espantadas. Havia ainda as que afrontavam os marchantes. Mas ninguém conseguia ficar indiferente, era impossível não ver, era impossivel não escutar. Sim, porque a marcha não é silenciosa ou cadenciada. Ela é alegre, tem trilha sonora e de tempos em tempos ouviam-se gritos de guerra.

$\mathrm{Na}$ volta ao estádio, me deparei com três senhoras com vassoura na mão, começando varrer o imenso estacionamento, onde horas antes se perfilaram os marchantes. Devagarzinho, sem que ninguém precisasse falar nada, elas deixaram tudo limpo. Assim também o fizeram as equipes de limpeza do ginásio e do estádio. A tarefa, no entanto, não foi nada simples, pois, com a falta d'água, não foi possivel lavar o chão.

No mesmo dia, à tarde, peguei um ônibus de Goiânia para São Paulo, pois tinha que assumir minhas aulas. ${ }^{39}$

Já em São Paulo, pude acompanhar a cobertura da mídia. Na TV o "Jornal Hoje", da rede Globo apresentou uma matéria. Nela falou da organização da marcha que contava com equipes funcionais identificadas pelas cores dos coletes. Falava também que quatro jornalistas acompanhariam a marcha e que nenhuma pessoa era autorizada a dar entrevista sem o consentimento da coordenação da marcha. Logo na seqüência, falava dos custos de uma manifestação como essa que, segundo eles, não era "espontânea", porque recebeu apoio da prefeitura de Goiânia e do Governo do Estado de Goiás, vindos do fundo de emergência, que deveria ser usado para dar "amparo a cidadãos necessitados” vítimas de enchentes ou catástrofes naturais. Podia-se concluir ao ver a notícia que os governos não deveriam estar

\footnotetext{
${ }^{39}$ Gostaria de marcar o apoio dado a essa pesquisa pelo Colégio Giordano Bruno, onde fui professora de história, no período do trabalho de campo.
} 
alimentando marchantes. Concluí que não se deveria alimentar os cidadãos que fazem luta política, ou que se atrevem a fazer da cidadania algo mais do que seu voto a cada dois anos.

Com aparente despretensão, no mesmo bloco de notícias foi apresentada a reportagem que falava sobre desabrigados de outros estados brasileiros e que vítimas de acidentes naturais estariam vivendo precariamente. Qualquer um poderia pensar, vendo aquelas notícias: por que o governo destina dinheiro aos sem-terra, que segundo a matéria, contavam com 22 mil marmitas, com cardápio específico por região brasileira, para 12 mil marchantes?

Aquele bloco do telejornal anunciava o perfil de cobertura que a mídia em geral dedicaria à marcha. Há que se dizer que o trabalho de acompanhar as notícias nos jornais e revistas não foi grande. Diferentemente de 1997, a marcha de 2005 que preenchia as estradas com doze mil pessoas ocupou um espaço bastante reduzido nas colunas da imprensa.

No tocante à cobertura da mídia, também gostaria de marcar que mesmo sendo quase sempre negativa, foi necessária para que esse evento fosse minimamente visto e se caracterizasse como uma forma de protesto. Caso contrário, a marcha aconteceria e ninguém ficaria sabendo, e seria como se não tivesse ocorrido.

Assim, a marcha que deveria ter iniciado no dia 17 de abril, ${ }^{40}$ apenas saiu de Goiânia no dia 2 de Maio. Uma das explicações do "atraso" foi a dificuldade de atrair a atenção da mídia. É verdade que a morte do papa ocupou a cena por dias e que seria dificil competir com tal evento. No entanto, é preciso também se destacar a dificuldade de se levantar recursos para a realização da marcha.

É importante assinalar a origem desses recursos. O que foi divulgado pelo MST é que parte significativa deles foi captada junto aos

\footnotetext{
${ }^{40}$ Entre os sem-terra, 17 de abril é uma data histórica. Em 1996, mais de três mil famílias ocuparam a fazenda Giacomet e formaram um acampamento do MST no maior latifúndio do Paraná; no mesmo dia 19 sem-terra foram mortos pela Polícia Militar do Pará, na chamada 'curva do S’ da Rodovia PA-150, nas proximidades de Eldorado dos Carajás. Em 17 de abril, um ano depois, terminava em Brasília a Marcha Nacional por Reforma Agrária Emprego e Justiça, uma caminhada de dois meses que começou em três diferentes pontos do território nacional. CHAVES, C. de A. Op Cit, p. 34.
} 
governos, mas houve outras fontes, como organizações internacionais, que enviaram dinheiro e representantes e os próprios assentados organizados pelo Movimento.

\section{$\underline{\text { A caminho }}$}

No saguão do aeroporto de Congonhas, aguardando meu vôo para Brasília, escrevi em meu caderno de campo:

“... é a primeira vez que estou viajando 'identificada'. Carrego comigo uma mochila com a bandeira do MST. Algumas pessoas olham, parecendo não acreditar, estranham. Outras nem olham, aliás não olhar é o que mais fazem. Falam muito ao celular, pouco entre si. Também não olham para os outros. Passam por aqui apressadamente exibindo trajes elegantes".

Esse é o não-lugar do qual nos fala Marc Augè ${ }^{41}$ ao definir que o excesso de espaços, contraditoriamente, constitui-se pelo encolhimento do mundo, em escala global, através da concentração urbana, migrações populacionais e produção de não-lugares aeroportos, vias expressas, salas de espera, centros comerciais, estações de metrô, campos de refugiados, supermercados, dentre outros por onde circulam pessoas e bens.

Segundo Augè, os não-lugares são não identitários, relacionais ou históricos. Em oposição ao "lugar antropológico" designado por Mauss, no qual "os nativos" vivem, celebram sua existência, residem, trabalham, guardam as tradições, ou seja, "é simultaneamente princípio de sentido para aqueles que o habitam e princípio de inteligibilidade para quem o observa". ${ }^{42}$

Ao se freqüentar os não-lugares revela-se um mundo provisório e efêmero, comprometido com o transitório e, mesmo em meio à multidão, com a solidão. Os não-lugares são a medida de uma época que se caracteriza pelo excesso factual, pela superabundância espacial,

\footnotetext{
${ }^{41}$ AUGÉ, M. Não-lugares: introdução a uma antropologia da supermodernidade. Campinas/SP: Papirus, 1994.

${ }^{42}$ Idem, p.51.
} 
pela individualização das referências e pelo consumismo. Ali naquele aeroporto, a caminho de uma marcha que reivindicava justamente o direito a lugares, espaços de terra, fazia essas reflexões.

Nessa sociedade do "ter", é dificil explicar o "ser". Esta pesquisa muitas vezes se deparou com essa contradição. Embora o "ser", de uma identificação Sem Terra, se forme a partir do "não ter". Afinal, apesar do fato de que o que une essas pessoas sob uma mesma bandeira é o fato de não possuírem terra, os sem-terra são mais do que aquilo que não têm e buscam, juntos, mais do que um pedaço de chão.

Parece paradoxal, em uma sociedade em que normalmente se é identificado com o que se tem, esses homens e mulheres unirem-se justamente entorno daquilo que lhes falta, por serem despossuídos, e construírem em torno dessa ausência uma de suas identidades. Ou seja, eles não "têm" e "são".

Mas o quê eles são? Não pretendo dar uma resposta definitiva a essa pergunta. A intenção é, no correr do texto, conhecer melhor os elos de ligação e de força desse grupo, os processos identitários e como eles foram sendo construídos. Por meio da ação de seus membros, o MST vem alargando o conceito de cidadania, ocupando os espaços públicos e, portanto, contribuindo para a consolidação do diálogo, da democracia em nosso país.

\section{$\underline{\text { Epílogo }}$}

Meu retorno à marcha aconteceu na última semana. Nesse segundo período de pesquisa pude contar com a companhia de Andrea Paula dos Santos, amiga de outros tempos e outras pesquisas. Para chegar ao "Sete Curvas", lugar em que estava a marcha, contamos com a ajuda de Patrícia Trindade Maranhão Costa $^{43}$ e Cristhian Teófilo da Silva. Os amigos antropólogos, entre muitas conversas, nos deram uma

\footnotetext{
${ }^{43}$ Devo dizer que ver Patrícia foi uma oportunidade de reencontro com a amiga dos tempos do ensino fundamental, quando morei em Brasília.
} 
carona de mais ou menos uns sessenta quilômetros.

Assim que chegamos, tivemos que nos identificar na portaria, e esperar alguém do estado de São Paulo vir nos buscar e mostrar onde estava a barraca do estado. Em meio à poeira vermelha do cerrado, estava montada uma cidade. Milhares de pessoas: homens, mulheres, crianças, jovens, indo e vindo pela "rua" principal, outras milhares dentro de suas tendas escondendo-se do sol ou descansando depois de terem marchado pela manhã. Algumas conversando, tocando violão, cantando. Cansados, mas felizes por se encontrarem.

Mas não era só a terra que era vermelha. As camisetas e bonés eram símbolos do Movimento que se faziam presentes, mostrando um processo de identificação que emergia coletivamente. Nos dias seguintes, a cada dia, vimos essa cidade se mover, com seus doze mil moradores.

Chegando à barraca de São Paulo, deparamo-nos com uma tenda branca, alta e retangular. Novecentos e cinqüenta colchonetes, dispostos um ao lado do outro em fileiras, formavam corredores imaginários, por onde era possivel caminhar. Os colchonetes não eram suficientes para amortecer as pedras e separar totalmente o corpo da terra que estava sob ele. Com a ajuda de Lurdes e de Nilcéia, velhas conhecidas, afastamos algumas pedras e alguns colchonetes e colocamos os sacos de dormir e as mochilas lá.

Durante os dias que participamos da marcha, o espaço foi sempre um problema. Delegações menores conseguiam ter maior conforto, mesmo não possuindo barracas com a estrutura da de São Paulo. Por exemplo, o Rio de Janeiro organizou barracas utilizando estruturas de estufas, cobertas com lona preta. Fazia menos frio à noite e muito calor durante o dia. Havia ainda as delegações pequenas, com não mais que duzentas pessoas. Assim juntavam-se na mesma barraca pessoas oriundas de estados como Maranhão, Pará e Piauí ou Ceará, Paraíba, Rio Grande do Norte e Distrito Federal.

Do meio para o final deste primeiro dia, resolvemos não começar nenhuma entrevista. Queriamos decidir o que fazer, acertar 
nosso roteiro para as entrevistas. Mais que isso, queríamos ficar com as pessoas de São Paulo que estavam nos acolhendo.

Mesmo decidindo não realizar entrevistas naquele momento, fomos nos apresentar para a coordenação do acampamento e fomos muito bem recebidas. As pessoas que encontramos lá nos conheciam de anos de trabalho e convivência e isso viabilizou o trabalho e o acesso às pessoas. Nesse primeiro dia, lembro de ter levado um e-mail sobre o trabalho a ser realizado, escrito por Roseli Caldart, e me apresentando como membro do setor de educação. Fomos então encaminhadas para a secretaria. Lá chegando encontramos Dirceu, que nos autorizou o uso de um colete de

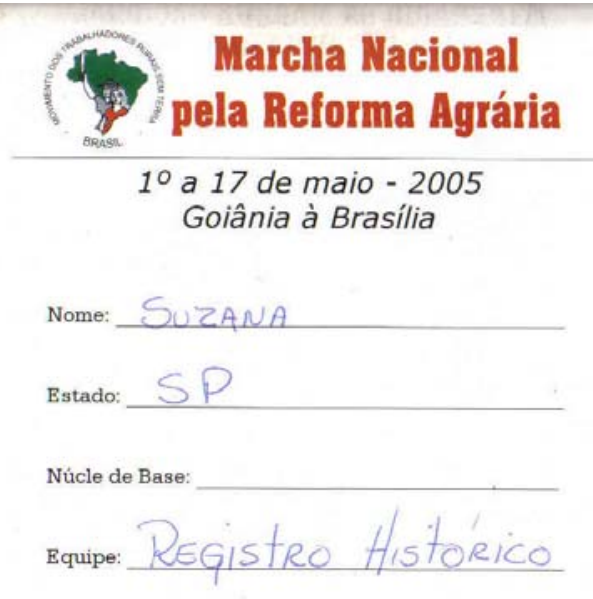

Reforma Agrária: Por um Brasil sem latifúndio! "imprensa" e fomos cadastradas como uma equipe, nomeada de Registro Histórico. ${ }^{44}$

Sem dúvida, o uso desse crachá e de um colete laranja, oficialmente, nos liberou para falar com quem quiséssemos como pessoas "de dentro" do Movimento. Isso evitou que fôssemos confundidas com jornalistas, que precisavam, por serem "de fora", ser acompanhados em suas visitas e contatos com pessoas.

$\mathrm{Na}$ maioria das vezes, as pessoas se dispunham a ajudar a pesquisa. Evidentemente, tivemos acesso a pessoas e histórias que não teríamos se fôssemos totalmente "de fora". No entanto, isso é também interessante, pois usar aquele colete simbolizava também como éramos vistas por aquela comunidade. Nem todos os pesquisadores ganharam coletes, mesmo alguns que estavam filmando ou fazendo entrevistas. O

\footnotetext{
${ }^{44}$ A equipe era formada por Andrea Paula e eu, sua criação foi sugestão nossa aos dirigentes do Movimento.
} 
projeto foi "adotado" e viramos uma equipe oficialmente cadastrada. Os jornalistas e membros da imprensa "de fora" recebiam um crachá de imprensa. Nossa marca era maior, mais visível.

Havia, entretanto, um entredito, próprio da posição de "fronteira" que ocupo junto ao Movimento. Evidentemente, não me pensava uma sem-terra, mas tampouco era uma pessoa que se deparava com o Movimento pela primeira vez. Talvez caiba ser explicado que penso que as pessoas entendiam essa situação. Assim o "recorte" do estudo de identidade vinculada a um movimento social como o MST deriva do fato de eu ter uma convivência longa nesse campo, seja como militante, seja como pesquisadora. Entretanto, creio que as questões levantadas aqui possam ser estendidas para outros campos de estudos das ciências humanas.

Esta não foi particularidade desta pesquisa. Estudos como os realizados por lideranças do Movimento como João Pedro Stédile, ou por intelectuais como Roseli Caldart e Bernardo Fernandes mostram que as fronteiras entre militância a pesquisa, provenientes do universo do observador e do observado, nem sempre se mantêm. Algumas dessas pessoas pertencem simultaneamente aos dois universos. Alguns militantes têm se tornado pesquisadores acadêmicos, ao desenvolverem pesquisas em universidades em nível de mestrado e doutorado. Assim como acadêmicos tornam-se autores de textos sobre o MST, mantendo intenso contato tanto com o mundo acadêmico quanto com a geração de políticas públicas em favor das demandas do movimento social.

Com isso, quero dizer que as experiências vividas junto a esse grupo facilitaram a entrada e a circulação nos acampamentos montados durante a marcha e foram grande incentivo para o registro de tantas entrevistas em um espaço curto de tempo.

Acho importante descrever o contexto que acompanhou a seleção dos colaboradores da pesquisa. Ele não foi homogêneo, de modo que entrevistamos pessoas que se ofereceram para participar, pessoas que selecionamos em conversas nas barracas dos diferentes estados e 
pessoas que foram selecionadas pelas coordenações dos estados a nosso pedido.

Neste último caso, entrávamos em contato com as coordenações de cada estado, para que indicassem uma ou duas pessoas para serem entrevistadas. Esse procedimento foi necessário, pois frente a um universo de quase 12 mil pessoas era dificil que eu e Andrea sozinhas selecionássemos todos os narradores. No entanto, pudemos perceber que isso representou um ganho ao trabalho. Primeiro porque, para as pessoas que iam contar a sua vida, terem sido indicadas pelo grupo dava uma segurança. Evitamos assim a repetição de indagações normais como: "mas eu não tenho nada para falar", "minha vida não é interessante" ou ainda "porque eu?!". Contar, com o apoio do grupo mostrado na seleção, se tornava menos penoso.

Assim que o colaborador era contatado, apresentávamos o projeto e gravávamos a entrevista. Embora fôssemos pesquisadoras conhecidas de muitos no movimento, a maioria dos entrevistados nunca tinha nos visto. Isso implicava em uma falta de proximidade entre entrevistadoras e entrevistados, o que algumas vezes se desdobrou em certa desconfiança e desconforto. Nesse sentido, a indicação de um nome, escolhido nas assembléias de cada estado, demonstrava o apoio do grupo e fazia com que isso fosse minimizado. Por outro lado, essa sondagem prévia, feita pelo grupo, garantia a possibilidade do entrevistado refletir sobre o que gostaria de falar sobre ele mesmo. Pensávamos que essa construção íntima de um "personagem" não poderia ser negada aos colaboradores da pesquisa. Esse tempo entre o momento do aceite em participar e o da gravação era um tempo de criação do entrevistado.

Com isso, alguns estados selecionaram seus "representantes". Músicos, militantes, acampados, assentados, homens ou mulheres, jovens ou velhos. Com o nome da pessoa indicada, iamos a sua procura, que ora era fácil e rápido, ora nem tanto. 


\section{Balanço de uma experiência}

"Estar lá" foi fundamental. Segundo Foucault "é preciso assistir ao nascimento de idéias e à explosão de sua força: e isso não nos livros que as ensinam, mas nos acontecimentos nos quais elas manifestam sua força, nas lutas que se travam por essas idéias, contra ou a favor delas". $45 \mathrm{O}$ autor vai além, ao afirmar: "não acho que o intelectual possa, com base unicamente em suas pesquisas livrescas, acadêmicas e eruditas, pôr as verdadeiras questões acerca da sociedade em que vive". 46

E quantas coisas aconteceram naqueles dias. Confesso que não foi fácil experienciar o estar lá naquelas precárias condições de acomodação: o calor durante o dia, o vento frio à noite, a falta de banheiros, a caminhada de 20 quilômetros, em média, por dia, as dores no corpo.

Naqueles dias, relatei em meu caderno de campo:

“... todos comentam que a estrutura dessa marcha é muito melhor que a das anteriores. No entanto, coisas básicas ainda são bastante dificeis. Os banheiros químicos são poucos e têm um cheiro insuportável. As pessoas preferem não usá-los e aos poucos o pudor vai sendo substituído pela necessidade. Os banhos são frios, cada grupo tem um balde para carregar sua água. A mesma utilizada para o banho enche as garrafas que matam a sede durante a caminhada".

Durante a pesquisa de campo notou-se que as mulheres participavam em menor número da marcha. Ao conversar com alguns militantes percebeu-se que isso é algo comum em manifestações em geral, e que o aumento da participação feminina é uma preocupação dos organizadores desses eventos. Mesmo assim, nessas conversas informais, a única explicação apresentada era que as mulheres, na maior parte das vezes, são as responsáveis pelos cuidados com os filhos, e por isso têm menor liberdade para deixar o lar. Mas a partir de

\footnotetext{
${ }^{45}$ Dits et éscrits (édition Quatro) II, 1978, n. 250, p.707, citado por GROS, F. (org). Op. Cit, p. 36.

46 "Entretien avec Michael Foucault", Dits et éscrits IV, p. 84, citado por GROS, F. (org). Op. Cit, p. $44 / 5$.
} 
minha experiência, pude perceber que existem outras questões que limitam a participação feminina. As especificidades da fisiologia - por exemplo o período menstrual ou de gravidez - somam-se à insuficiência de instalações sanitárias e estruturas de saúde e desencorajam as mulheres a se fazerem mais presentes.

Apesar de todas as dificuldades, esse foi um jeito de entrar em contato com o acontecimento no qual a idéia da identidade "Sem Terra" se manifestava com uma força incrivel.

Esse balanço das vivências que tive torna-se importante à medida que foram contornando o significado do conceito de experiência. Nesse sentido, destaco as reflexões tecidas por dois autores: Walter Benjamin e Edward Thompson.

A primeira leitura foi a de Benjamin, mas foi depois de ler Thompsom que pude entendê-lo. Thompson apresentou esse conceito, numa perspectiva cultural, a experiência humana como mediação necessária entre o ser social e a consciência social. Pois, para ele, é a experiência que dá cor à cultura, aos valores e ao pensamento. ${ }^{47} \mathrm{Diz}$ que as pessoas não experienciam apenas idéias, no âmbito do pensamento e de seus procedimentos. Experimentam sua experiência como sentimento e "lidam com esses sentimentos na cultura, como normas, obrigações familiares e de parentesco, e reciprocidades, como valores ou na arte ou nas convicções religiosas". 48

Depois, retomou-se a leitura de "O narrador" em que Benjamin coloca a importância da experiência para a constituição de um narrador. Sei que é comum nos trabalhos de história oral retomarse esse texto para, ao contrário de Benjamin, afirmar: o narrador não morreu. A intenção aqui é ponderar e retomar suas reflexões sobre a experiência como substrato de onde emerge a narrativa. Destaco aqui a passagem: "o narrador retira da experiência o que ele conta: sua própria experiência ou a relatada pelos outros. E incorpora as coisas narradas à

\footnotetext{
${ }^{47}$ THOMPSON, E. P. A miséria da teoria ou um planetário de erros. Rio de Janeiro, Ed. Zahar, 1981, p.112.

${ }^{48}$ Idem, p. 189-190.
} 
experiência de seus ouvintes”. ${ }^{49}$ Essa experiência, para Benjamin, circunscreve-se ao viver, ligado ao trabalho. Experimentar é viver no corpo e na alma e nessa medida:

A alma, o olho e a mão estão assim inscritos no mesmo campo. Interagindo, eles definem uma prática. Essa prática deixou de nos ser familiar. O papel da mão no trabalho produtivo tornou-se mais modesto, e o lugar que ela ocupava durante a narração está agora vazio. (Pois a narração, em seu aspecto sensivel, não é de modo algum o produto exclusivo da voz. Na verdadeira narração, a mão intervém decisivamente com seus gestos, aprendidos na experiência do trabalho, que sustentam de cem maneiras o fluxo do que é dito.) ${ }^{50}$

Percorrido esse caminho, trabalhando de perto com o Movimento, pude perceber que a experiência era um dos pilares de identificação e que essa questão servia como reforço para um discurso de luta e ao mesmo tempo era transformada pelas estratégias empregadas pelos novos sujeitos resultantes desse processo.

A história, aqui contada, é pensada e realizada por pessoas que impulsionam a ação do Estado, e assim fazem política e escrevem sua história "a contrapelo".51 Portanto, para "estudá-los", eram imprescindíveis critérios como a existência de uma relação entre sujeito-sujeito em detrimento da relação sujeito-objeto, mudando o conteúdo dessa pesquisa. Compartilhar algumas experiências ampliou a possibilidade de diálogo. O projeto foi aberto para novas questões e os narradores colaboraram com a busca de respostas. O narrador, portanto, não é uma "fonte" ou um "informante" que "depõe" sobre uma "realidade".

Esse posicionamento se contrapõe ao que mais comumente acontece, ao estabelecer-se que existe um sujeito pesquisador e um objeto a ser pesquisado. Essa mudança de postura permite uma maior interação e liberdade comunicativa entre os envolvidos. O pesquisador pode, dessa forma, aprender mais com seus colaboradores,

\footnotetext{
${ }^{49}$ BENJAMIM, W. Op.Cit. p. 201.

${ }^{50}$ Idem, p. 221.

${ }^{51}$ BENJAMIN, W. Sobre o conceito de história. IN: Obras escolhidas: magia e técnica, arte e política. São Paulo: Brasiliense, 1985, p. 225.
} 
estabelecendo uma comunicação, na medida do possível, "não violenta" 52 , minimizando as relações de poder normalmente presentes nas situações de entrevistas ou conversas.

Esse procedimento ético-metodológico passa a exigir do pesquisador um outro posicionamento frente à criação e análise de "seus" documentos. A experiência é valorizada. Não por serem essas pessoas "testemunhas" de um passado, ou por acreditar que se possa "resgatá-lo" por meio das tramas registradas, mas por poder ver os processos de negociação que aconteceram para que se conte uma versão do passado, e se repense uma vida a partir das inquietações e tensões do presente.

As entrevistas foram estabelecidas como representações de um passado. São formulações de um presente que estabelece relações e relê o passado pelo filtro do que se quer resolver e entender no presente. Essa possibilidade interpretativa de ter acesso à fala do outro e estabelecer redes de ligação para o grupo permitiu perceber com o que as pessoas se identificam e o que escolhem contar. Esse modo de pensar hermenêutico foi a base para que esse projeto realizasse a seleção e o ordenamento de passagens do passado para a montagem das identidades dos sem-terra no presente.

O objetivo geral dessa primeira parte do trabalho foi apresentar as "Narrações e narrativas" produzidas por essa pesquisa. Destacaram-se os textos resultantes da gravação das entrevistas dos colaboradores, seguidos de uma descrição do trabalho de campo. Importante salientar que tanto os primeiros textos quanto o segundo são resultado de uma negociação, estabelecida em uma relação entre os vários sujeitos envolvidos no processo de pesquisa, que valoriza a experiência e a subjetividade. As narrações e as narrativas dos sujeitos envolvidos na pesquisa são os elementos de onde análises e leituras, passo a passo, vão se tramar nessa tese.

\footnotetext{
${ }^{52}$ Conceito desenvolvido por BOURDIEU, P. A miséria do mundo. Rio de Janeiro: Vozes, 1997, p. 695 e também por PORTELLI, A. Elogio de la grabadora: Gianni Bosio y los orígenes de la historia oral. Revista história 30, México: Abril 1993 - Septiembre 1993, pp. 3-8.
} 


\section{Parte II}

Memórias e Identidades:

para além de uma e outra 


\section{Memórias e narrativas: percepcões negociadas}

Estou feliz de ter contado minha história. Foi muito bom ter participado dessa pesquisa. Falar dos outros, é fácil. Mas a partir do momento que vai falar da sua história fica pensando, relembra tudo o que aconteceu $e$ isso é um exercício muito bom. Voltando ao passado, reflete algumas coisas que futuramente vai melhorar. Faz essa reflexão da sua vida toda, isso é muito bom. Gostei muito mesmo de dar a entrevista. Ana Paula

Essa parte do trabalho propõe uma reflexão sobre a forma com que os narradores escolheram rememorar e narrar suas histórias, apresentando como essas histórias se conformaram durante a pesquisa. Como apontei anteriormente, todas as reflexões foram estimuladas e estão em diálogo com o fazer das entrevistas e seu conteúdo. Também coloco a explicação do uso da história oral sob a ótica da pesquisadora e dos entrevistados, que, de forma combativa, fizeram críticas, apontaram caminhos e se manifestaram sobre a organização da pesquisa, além de mostrarem limitações da mesma.

Tá gravando já?... - Adelir

A primeira ponderação a respeito da realização das entrevistas é que todas foram gravadas com autorização da pessoa que narrou sua história. No entanto, com freqüência, desde esse minuto inicial foi preciso uma ação de negociação, de mediação com respeito à presença do gravador. Ele interfere. Sua presença intimida. Mas isso não impede a narração. Algumas vezes ele foi desligado durante as entrevistas, a pedido do entrevistado. Na maioria das vezes, isso se dava para que a pessoa tivesse tempo de organizar seus pensamentos e racionalizar sua narrativa.

Por saber que fazer uma seleção faz parte do processo de narrar é que apresento as narrativas como tramas biográficas, conceito 
utilizado por Sarlo. ${ }^{53}$ Por isso também foi necessário respeitar o narrador, e desligar o gravador em momentos em que a emoção de um choro, por exemplo, aparecia na entrevista. Nessas situações, muitas vezes o gravador, que minutos antes parecia não existir para o narrador, se tornava um interlocutor extremamente violento. Era capaz de registrar e tornar público um momento de tensão. Nesses instantes, de incômodo, a iniciativa de desligá-lo era minha. Pois como afirmou Adelir: "É difícil falar numa entrevista assim... O gravador às vezes assusta um pouco..."

Não é apenas o gravador que assusta, toda a situação de entrevista é bastante delicada. Muitos narradores não se sentem à vontade para acessar suas lembranças e compartilhá-las. Especialmente quando se narra episódios de violência e exclusão. É preciso refletir sobre o trabalho da memória e a dificuldade de narrar nossas próprias histórias. Não é apenas a presença do gravador que faz com que seja dificil dar uma entrevista. A entrevista em si mesma é um exercício, momento em que como em um tecido, deve-se tramar os fios, cruzar lembranças para criar um enredo com as experiências de uma vida.

Nas palavras de Eclea Bosi:

$\mathrm{Na}$ maior parte às vezes, lembrar não é reviver, mas refazer, reconstruir, repensar, com imagens e idéias de hoje, as experiências do passado. A memória não é sonho [Bergson], é trabalho. (...) A lembrança é uma imagem construída pelos materiais que estão, agora, a nossa disposição. ${ }^{54}$

Assim, uma pessoa, ao se lembrar de algo, reconstitui imagens, eventos, sentimentos que foram "experimentados", ou melhor, ela os experiência, vivencia de modos diversos, antes no passado, agora no presente. Passagens da vida são reconstruídas, representadas a partir de um novo repertório. Essa reconstrução, para Bosi, ganha uma função social que, ao se contrapor a uma massiva presentificação do mundo atual, tem caráter de resistência que é capaz de, junto à

\footnotetext{
53 SARLO, B. Op. Cit., 2007.

${ }^{54}$ BOSI, E. Memória e sociedade. Lembrança de velhos. São Paulo: Cia das Letras, 1994, p.55.
} 
"rebeldia da memória", recompor algumas passagens da vida "em seu lugar antigo". 55

Dessa forma, o trabalho que os narradores tiveram, de relembrar e contar suas tramas e traumas tem que ser reconhecido e respeitado pelo entrevistador, pois:

...articular um discurso sobre si mesmo é uma tarefa extremamente árdua para indivíduos das classes muito baixas. (...) A construção biográfica os obriga a ver, lembrar, tomar conhecimento mais global, tarefas muito árduas emocionalmente. 56

Essa reflexão mostra que já há algum tempo se pensa nas dificuldades de expressão de grupos sociais mais pobres. Pode-se acrescentar que não apenas para esses sujeitos essa construção é uma tarefa que exige atenção e trabalho, mas para todos. De qualquer forma, não se pode esquecer que os colaboradores que fizeram parte desse trabalho, narrando suas vidas, são cidadãos comuns de origem social bastante simples que encontraram no Movimento uma forma de participarem de uma comunidade, pois:

... a comunidade é o lugar "cálido", um lugar confortável e aconchegante. É como um teto sobre o qual nos abrigamos da chuva pesada, como uma lareira diante da qual esquentamos a mão diante de um dia gelado. Lá fora, na rua, toda sorte de perigo a espreita; temos que estar alertas quando saímos (...) $\mathrm{Na}$ comunidade podemos relaxar - estamos seguros, não há perigos ocultos em cantos escuros (com certeza, dificilmente um "canto" aqui é "escuro"). 57

Todos os colaboradores mostram-se acolhidos e seguros no MST, e na maior parte de suas narrativas mostram ter assumido seu argumento, seu discurso. Por isso mesmo, argumenta-se que um recurso usado por alguns narradores, para quebrar momentos de tensão ou muita emoção enquanto narravam suas histórias, era entremear sua fala sobre um cotidiano muito sofrido - enunciando a exclusão - com um discurso militante - falando da inclusão.

\footnotetext{
${ }^{55}$ Idem, p.452.

${ }^{56}$ RODRIGUES, A. M. Operário, operária. São Paulo: Símbolo, 1978, 63-4.

${ }^{57}$ BAUMAN, Z. Comunidade: a busca por segurança no mundo atual. Rio de Janeiro: Jorge Zahar Editor, 2003, p.7-8.
} 
Interessante pensar que ambos são discursos dessa comunidade negociados e enunciados a partir das subjetividades envolvidas.

Esse ir e vir - entre diferentes discursos - mostra a releitura que cada sem-terra faz de sua própria vivência e o conforto oferecido pelas certezas do discurso político. Paralelamente, mostra também os mecanismos pelos quais se escolhe ou não narrar algo, e evidencia o trabalho de trama do que pôde ser dito.

Ao pensar, mais detidamente, sobre esses enunciados, interessa o exercício de refletir sobre o uso da voz passiva e voz ativa. Elas são indícios, que marcam a diferença entre vidas diferentes. Isso se evidenciou em uma passagem do texto da entrevista de Adelir:

Por exemplo, em todos os espaços que nós passamos, foi visto pessoas morando embaixo do viaduto, pedindo esmola... as grandes favelas que nós vimos no caminho.

As pessoas que vivem em situação de exclusão, são vistas. A voz passiva nesse contexto exprime uma situação de sujeição. Mesmo que a concordância da sofisticação da voz passiva, por vezes seja subvertida, seu significado semântico está presente. Na voz passiva, as pessoas não são agentes de transformação, estão em uma posição de subordinação. Diferente dos sem-terra que se assumem como sujeitos históricos.

Logo em seguida, os sem-terra vêem as grandes favelas. $\mathrm{Na}$ voz ativa, Adelir expressa sua agência junto a seu grupo. Não diz "eu vi", e sim "nós vimos". Outra reflexão é que a possibilidade de ver se dá no caminho, em meio à marcha. Ou seja, a marcha é vista como um momento de formação em que se celebra a união do grupo e se pode ver a diferença entre "nós e os outros".

Durante a leitura das narrativas a repetição constante, às vezes cansativa, do nós e do a gente marca esse pertencimento e reforça a idéia do agir e se ver como sujeito da história.

Ainda pensando na organização do que foi contado e na seleção de expressões, destacam-se palavras como construir e lutar que aparecem com freqüência nas histórias de vida. Se a narrativa é 
construção tramada, não se pode pensar que o vocabulário escolhido é inocente. A escolha desses termos denota um sentido de processo que depende da ação de todo um grupo.

Por sua vez, esse grupo aparece definido pelos vocábulos Movimento e organização, ambos significando o Movimento dos Trabalhadores Rurais Sem Terra. Movimento é uma forma rápida e carinhosa de se referir ao grupo, sem a frieza de uma sigla. Organização é uma forma de nomear o MST destacando uma de suas qualidades. Por vezes, aparecem também palavras como organicidade e infraestrutura se referindo ao funcionamento do MST.

A escolha vocabular fica ainda mais evidente no uso do termo ocupação ao invés de invasão. Essas palavras têm significados bem distintos, e, portanto, essa nomenclatura para a ação praticada pelos sem-terra marca um posicionamento. Reconhece-se que a terra deve ter um uso social, como o previsto pela Constituição Nacional. Justifica-se que algo deve ser feito, nas ocasiões em que ela não está sendo utilizada, tendo ou não um proprietário. Assim, quando a terra está "vazia", ocupá-la é direito dos que nela querem trabalhar. Além disso, a escolha do termo marca uma diferença entre o discurso da mídia e de órgãos públicos. Invasão, utilizado pelos "outros", respeita uma lógica capitalista e carrega em seu significado um sentido negativo, que dá às ações públicas do MST um caráter de ilegitimidade e ilegalidade que deve ser melhor discutido.

Outra escolha vocabular cheia de significados ocorre com termos educando e educador, em lugar de aluno e professor. Essa troca é realizada porque o MST acredita em um processo educativo de aprendizado conjunto e mútuo. Contrapõe-se, portanto, à idéia de que alguém seja capaz de professar verdades sobre um tema, e que outro possa ser iluminado por essas instruções vindas de uma vivência diferente, que em nada tenha relação com a sua. A definição dos termos lembra a todos que o enunciam uma opção teórica e metodológica, marcando um posicionamento educacional. 
Com isso, passa-se a empregar termos próprios. Para finalizar essa reflexão sobre palavras escolhidas para denominar coisas e ações, gostaria de indicar alguns nomes escolhidos para assentamentos e acampamentos: Antônio Conselheiro, Che Guevara, Chico Mendes, Dandara, Florestan Fernandes, Paulo Freire, Zumbi dos Palmares. Ou ainda a designação dada às escolas: Grito do Sepé, Antônio Conselheiro, Carlos Mariguela, Florestan Fernandes e Josué de Castro. 58 Esses são nomes representativos das lutas e conquistas populares. São eles os patronos escolhidos pelos membros do Movimento. São os nomes representativos.

Além de nomes como esses, acampamentos podem ser nomeados com expressões que justificam a luta e referem-se a uma história da religiosidade e da exclusão, como no caso da entrevista de Wanderléia, em que ela faz questão de contar que seu acampamento foi batizado como "Terra Prometida". Expressão cheia de significado religioso, deixa claro o simbolismo de uma busca.

$\mathrm{O}$ uso de tal vocabulário intencional e justificado define um modo de ser, de pensar e de lembrar de uma coletividade. As narrativas, ao usarem essas palavras, demonstram uma apropriação e também uma trama de seleção da memória. Uma memória que dá vida à história, contesta o uso de palavras e conceitos cristalizados.

Essas palavras comuns mostram, portanto, que há uma memória compartilhada por esse grupo.

O vocábulo memória foi utilizado apenas na entrevista de Aquiles. Entretanto, nessa narrativa ele apareceu com dois significados bastante distintos. Da primeira vez, mostrou-se no seguinte contexto:

Às vezes, a gente está aqui, porque tinha um costume de ter andado do Rio de Janeiro à Brasília... Porque participou da marcha de maior distância que já teve do Movimento Sem Terra. Foram 72 dias, caminhando direto, e a gente cria aqui na memória da gente. É tipo jogo de futebol. Quando bota na memória que todo dia de manhã tem que jogar bola, então todo dia de manhã tem que fazer isso!

\footnotetext{
${ }^{58}$ Um levantamento mais completo foi feito por Sebastião Vargas, mas ainda não foi publicado.
} 
Da segunda vez:

Acho que a presença do Movimento Sem Terra está no rosto, na memória, no nosso falar.

A exemplo desses dois excertos, memória pode ser pensada como hábito, de acordo com a primeira afirmação. Mas também como forma de ser, como identidade, conforme a segunda. O uso da palavra memória por Aquiles conduziu a uma reflexão sobre os trabalhos de muitos pensadores que refletiram sobre ato de lembrar ou rememorar.

\section{Sobre memória}

Propõe-se, então, um breve balanço do caminho percorrido para a construção desse conceito. A intenção é conhecer um pouco da produção em torno do conceito de memória, pontuando alguns autores de diferentes áreas do conhecimento que se detiveram a estudá-lo.

Importante lembrar que, para a construção desse conceito que hoje está tão vinculado ao fazer da história, sociólogos e etnólogos precederam amplamente os historiadores. E mesmo hoje, os usos do conceito são bastante diferenciados, pois enquanto alguns historiadores buscam investigar o passado através da memória, procurando os diversos componentes que constituíram os contextos do passado, a maior parte dos sociólogos e antropólogos elege a memória como elemento para a compreensão da constituição de práticas e comunidades do agora, procurando compreender o presente a partir das reconstruções que são feitas. Assim, o conceito de memória pode ser associado tanto a processos interativos quanto a construções simbólicas já constituídas. ${ }^{59}$

É importante observar que as memórias são resultado de experiências vivenciadas mesmo que deixem poucos traços de si em

\footnotetext{
${ }^{59}$ Ver: ANDERSON, B. R. Imagined communities: Reflections on the origin and spread of nationalism. London; New York: Verso, 1991.
} 
nós, ou mesmo que a transformemos. O filósofo Henri Bergson, no seu trabalho sobre a memória, ${ }^{60}$ descreveu dois tipos de rememoração, a lembrança-hábito e a lembrança que reconhece imagens e movimentos do passado, "das quais uma imagina, a outra repete". ${ }^{61} \mathrm{O}$ primeiro tipo, que se faz presente em ações e atividades da vida cotidiana, "como o hábito, ela é adquirida pela repetição de um mesmo esforço". 62 O segundo "é como um acontecimento de minha vida; contém por essência, uma data, e não pode conseqüentemente repetir-se",63 ou seja, refere-se à recordação de um evento do passado. Bergson atribuiu à memória a capacidade de unir estes dois planos de experiência; além de permitir uma consciência espaço-temporal. Essa forma de caracterizar a memória e as lembranças, em especial a autonomia entre elas conceituada por Bergson, foi bastante criticada por pensadores como Benjamin e por autores mais recentes.

Outra reflexão que merece destaque está nos trabalhos do sociólogo Maurice Halbwachs, pioneiro ao apresentar a memória como fenômeno social. Halbwachs analisava, em 1935, a memória familiar, a religiosa e dos grupos sociais e mais tarde preocupou-se com a questão da memória coletiva como modo de conformar e determinar as memórias individuais, variando de acordo com o lugar social que é ocupado. Para o sociólogo, por mais que pareçam expressar experiências individuais, as memórias são constituídas por estruturas sociais mais amplas que antecedem a do individuo.

Ele se deteve no estudo das relações entre indivíduo e sociedade e para isso cunhou o conceito de comunidade afetiva, base para a formação da memória coletiva. É importante lembrar que o sociólogo apontou esta memória coletiva como plural e múltipla, legitimada em um espaço e em um tempo (sempre negociado entre passado e presente). A capacidade de se combinar de diferentes formas

\footnotetext{
${ }^{60}$ BÉRGSON, H. Matéria e memória: ensaio sobre a relação do corpo com o espírito. São Paulo: Martins Fontes, 1990.

${ }^{61}$ Idem, p. 63.

${ }^{62}$ Idem, p.61.

${ }^{63}$ Idem, ibdem.
} 
faz com que a relação entre memória individual e memória coletiva nunca seja única e constante.

O conceito de comunidade afetiva é fundamental para entender um grupo frente ao trauma que o formou. As perdas impõem uma nova situação de vida e muitas vezes passam a definir o grupo. O exemplo de Halbwachs são os judeus nos campos de concentração que perdem seus bens materiais, sua família, sua saúde... Mas não perdem sua memória.

Aqui, traça-se um paralelo com o caso dos sem-terra que despossuídos, reconquistam seus bens, sua saúde e por vezes reconstituem suas famílias ao participarem do Movimento. Da vida anterior, guardam suas memória.

Ao mesmo tempo, essa memória das experiências traumáticas é o que possibilita um reviver do horror, que faz com que se possa pensar em paradoxos, como o apontado pela professora de filosofia Susan Brison:

The paradoxes of traumatic memory may seem to defy analysis. Our ordinary concepts of time and identity cease to apply, as in the French writer Charlotte Delbo's statement. "I died in Auschwitz, but no one knows it"(1995, 267). ${ }^{64}$

A vivência da exclusão e de ser despossuído, na visão dessa pesquisa, faz com que os sem-terra, assim como os judeus para Halbwachs, se tornem uma comunidade afetiva ligada por suas memórias coletivas. Pois, pode-se dizer que suas memórias conformamse a partir de perdas significativas a que foram historicamente submetidos. Isso traz à tona a discussão sobre traumas por eles experienciados no decorrer de suas vidas.

"A memória coletiva", título de seu livro póstumo, ${ }^{65}$ passa a ser tratada como fato social a ser estudado, colocando em diálogo os campos da sociologia e da psicologia. Esse diálogo, contemporaneamente, tem sido retomado por Eclea Bosi, que com os

\footnotetext{
${ }^{64}$ BRISON, S. J. Aftermath: violence and the remaking of a self. Princeton, NJ: Princeton University Prress, 2003, p. XI.

${ }^{65}$ HALBWACHS, Op. Cit., 1990.
} 
livros "Memória e sociedade" e "O tempo vivo da memória"66 revisitou grandes teóricos das humanidades para promover um debate em torno do conceito de memória. Dentre esses pensadores, dá destaque às obras de Bergson, de Halbwachs e de Benjamin.

Em “O tempo vivo da memória” apresenta-se logo de início uma importante questão, acompanhada de sua resposta: "O movimento da recuperação da memória nas ciências humanas será moda acadêmica ou tem origem mais profunda com a necessidade de enraizamento? Do vínculo com o passado se extrai a força para a formação de identidade". 67

Com isso, revela-se a ligação entre memória e identidade, que necessita da narração para ser evidenciada e compreendida. $O$ ato de rememorar é traduzido em palavras de uma narrativa. Por meio dessa, outras pessoas - ou mesmo o próprio narrador - tomam consciência de suas vidas, de suas experiências. Descobrindo-se quem é, revela-se uma identidade. A memória traduzida em palavras transmite uma experiência vivida e explica o comportamento do presente.

Eclea agrega uma perspectiva individual e coletiva às narrativas. Segundo Ades afirmou sobre o livro de Eclea:

Cada relato remete a situações em que o depoente se envolveu em interação com outras pessoas, reflete as crenças que adquiriu em seu grupo, se ancora temporalmente aos eventos que fizeram notícia e qualificaram a época, sobre campeonatos de futebol, sobre acidentes e crimes, sobre escândalos e política (...). A vida "privada" constitui o testemunho de um tempo coletivo, e o psicólogo social pode remontar, a partir das práticas da privacidade, para o contexto social do qual se nutrem e que elas ajudam a definir. Nesta empresa, a psicologia estabelece zonas de transição e de interdisciplinaridade com a história e as outras ciências sociais. ${ }^{68}$

Afirmações como essa, conduzem às reflexões como a de Le Goff que definem a memória:

\footnotetext{
${ }^{66}$ BOSI, Op. Cit, 1994, BOSI, E. O tempo vivo da memória: ensaios de psicologia social. São Paulo: Ateliê Editorial, 2003.

${ }^{67}$ BOSI, Op. Cit, 2003, p.16.

${ }^{68}$ ADES, César. A memória partilhada. Resenha de Bosi, Ecléa. O Tempo Vivo da Memória: ensaios de Psicologia Social. In: http://www.scielo.br/pdf/pusp/v15n3/24613.pdf, acessado em 11/01/07.
} 
... como propriedade de conservar certas informações, remetenos em primeiro lugar a um conjunto de funções psíquicas, graças às quais o homem pode atualizar impressões ou informações passadas, ou que ele representa como passadas.

Deste ponto de vista, o estudo da memória abarca a psicologia, a psicofisiologia, a neurofisiologia, a biologia e, quanto às perturbações da memória, das quais a amnésia é a principal, a psiquiatria (...). Certos aspectos do estudo da memória, no interior de qualquer uma destas ciências, podem evocar, de forma metafórica ou de forma concreta, traços e problemas da memória histórica e da memória social. 69

Existe uma reflexão multifacetada de diversas disciplinas sobre o conceito de memória, reflexões estas que em parte, sob o recorte das humanidades, estão sendo tratadas aqui, mas interessa também, em uma tese de história social, pensar um pouco sobre como o tema foi abordado no campo dos historiadores.

Ao fazer tal colocação, cabe pensar o quanto da história é abarcado pela memória, que se tornou tema com alguma relevância para a produção historiográfica após a década de 1970 com os trabalhos dos historiadores da Nova história. Ou seja, a noção de memória apareceu tardiamente no campo do historiador. Em 1961, Alphonse Dupront observou que a memória coletiva é a própria substância da história, mas foi preciso esperar até 1978, para que Pierre Nora reconhecesse seu valor, sendo que para ele o conceito tinha as mesmas implicações que a palavra mentalidade há 30 anos, e sua utilização estratégica também poderia ser fecunda para a renovação da historiografia. ${ }^{70}$

A história metódica e factual passou a ser questionada, assim como seus estudos centrados nos "grandes eventos históricos" e suas "personalidades", que haviam dominado a historiografia até a primeira metade do século XX.

O surgimento da Ècole de Annales, na década de 1920, foi o detonador dessas mudanças e seus fundadores ampliaram os limites do

\footnotetext{
${ }^{69}$ LE GOFF, J. História e memória. Campinas, SP: Ed. Unicamp, 1996, p. 423.

${ }^{70}$ SOTO, A. Historia y Memória. In: http://www.angelsoto.cl/2006/02/historia_y_memoria.html, acessado em 10/01/07.
} 
campo de estudos da história. Historiadores como Marc Bloch e Lucien Febvre propuseram a diversificação de temas, e "pessoas comuns" passaram a fazer parte de uma "Nova história" que relativizava os "acontecimentos", priorizava as "estruturas" para a produção do conhecimento em história. Além disso propuseram, junto aos demais pensadores dessa escola, o debate sobre o que é documento para a história. Esse foi um grande passo para a diversificação do uso de fontes, que passou a englobar a iconografia, a literatura e as artes. Desde então os historiadores vêm derrubando barreiras e investindo em "novas abordagens" e "novos objetos de pesquisa", cada vez mais ligados às ações humanas.

O evento histórico perdeu importância frente à hipótese de trabalho e passou a ser problematizado em função de um contexto mais amplo de rupturas, transformações sociais e culturais. Os Annales defenderam uma história-problema, ou seja, a pesquisa histórica deveria servir para iluminar e responder a uma problematização colocada pelo historiador e que se desenharia no percurso da investigação.

La nouvellle histoire veio acompanhada de muitas mudanças tanto no conceito de história quanto no de documento. Com o advento da história do tempo presente esses documentos passaram a ser retirados do cotidiano, e a própria vivência das pessoas passou a fazer parte do conjunto de interesses do pesquisador da área de história.

Segundo a história do tempo presente, toda história é sempre contemporânea, pois o que se busca explicar no passado é o que nos preocupa hoje. Assim, os temas são selecionados a partir da formulação de uma problemática do presente. Isso garante à história um constante movimento, um processo dinâmico, que se afasta de conceitos cristalizados como verdade e neutralidade. A história oral, por sua vez, potencializa esse movimento, na medida em que o pesquisador passa a se relacionar com seres vivos que influenciam, emocionam e transformam o papel do pesquisador. 
O documento, qualquer que seja ele, passa a ser a via pela qual se concretizará a possibilidade do historiador responder suas questões. A "revolução" no conceito de documento culminou na possibilidade do uso da própria história de pessoas. No entanto, se as tramas biográficas, ou narrativas sobre o viver, foram "promovidas" a documentos históricos, era necessário conhecer mais sobre a memória, que as alimentava.

Essa nova prática de pesquisa envolveu em dúvidas os historiadores. Como poderiam acreditar na memória das pessoas? E se ela falhasse, se enganasse? E se deliberadamente mentisse? A memória se apresentava como algo fluído, um espaço da incerteza, o que, portanto, impediria a ciência histórica apoiar nela suas certezas.

Foi longo o caminho percorrido pelo conceito de memória até chegar ao reconhecimento contido na afirmação de Le Goff:

O estudo da memória social é um dos meios fundamentais de abordar os problemas do tempo e da história, relativamente aos quais a memória está ora em retraimento, ora em transbordamento.

No estudo histórico da memória histórica é necessário dar uma importância especial às diferenças entre sociedades de memória essencialmente escrita como também às fases de transição da oralidade à escrita, a que Jack Goody chama 'a domesticação do pensamento selvagem'. ${ }^{71}$

A memória, que já tinha seu espaço garantido no campo de outras disciplinas, começava a conquistar terrenos e a fazer parte das preocupações dos historiadores. O detalhe foi valorizado. A alteridade ganhou destaque nos estudos e assim vozes silenciadas passaram a ser ouvidas e o processo histórico a registrar sua imensa diversidade. Mesmo que para isso:

A memória, para poder ser tornada histórica, gozar das prerrogativas de cientificidade, ou pelo menos aspirar ser fonte histórica com credibilidade dentro da 'província' dos historiadores precisa, necessariamente, passar pelo processo crítico que chamaremos pelas expressões teorização e metodização. Teorizar significa pensar a memória - como fonte histórica em termos de especificidade científica como elemento

\footnotetext{
${ }^{71}$ LE GOFF, Op. Cit, 1996. p. 426
} 
contextualizado de interpretação histórica. Significa perspectivar a memória como elemento de orientação sobre a experiência do passado humano. Teorizar representa as diversas estratégias de argumentação na forma de teorias explicativas e de interpretação. Em outras palavras, seria o caso de perguntar como cada teoria ou referencial teórico irá perspectivar o passado, dando-lhe sentido e significação. ${ }^{72}$

De qualquer modo, é fato que as pesquisas em torno do uso da noção de memória se multiplicaram e seu êxito se relacionou à redescoberta dos pequenos grupos de pertença, com a vontade de reencontrar, salvaguardar ou mesmo constituir sua identidade. Caminho trilhado por Le Goff ao teorizar e dar sentido ao conceito de memória usado pela história:

A memória é um elemento essencial do que se costuma chamar identidade, individual ou coletiva, cuja busca é uma das atividades fundamentais dos indivíduos e das sociedades de hoje, na febre e na angústia.

Mas a memória coletiva é não somente uma conquista, é também um instrumento e um objeto de poder. São as sociedades cuja memória social é sobretudo oral ou que estão em vias de constituir uma memória coletiva escrita, que melhor permitem compreender esta luta pela dominação da recordação e da tradição, esta manifestação da memória. ${ }^{73}$

Pierre Nora teve também grande importância nesse debate, contribuindo com a noção de lugar da memória, que foi amplamente popularizada, e que pode ser concebida como um ponto em torno do qual se cristaliza uma parte da memória nacional (locais de identificação entre memória e história). O "lugar de memória" foi definido por Nora na apresentação de Les France como "toda unidade significativa, de ordem material ou ideal, da qual a vontade dos homens ou o trabalho do tempo fez um elemento simbólico do patrimônio da memória de uma comunidade qualquer". ${ }^{74}$

Dessa forma destaco outra grande contribuição de Nora, ao discutir o fim da história-memória e a memória tomada como história.

\footnotetext{
${ }^{72}$ DIEHL, A. A. Cultura historiográfica. Memória, identidade e representação. Bauru, SP: EDUSC, 2002. p.119.

${ }^{73}$ LE GOFF, Op. Cit, 1996. p. 476.

${ }^{74}$ NORA, P. Les France, Paris, Gallimard,1984, p.20, citado por ENDERS, A. Les Lieux de Mémoire, dez anos depois. In: http://www.cpdoc.fgv.br/revista/arq/119.pdf, acessado em11/01/07.
} 
Tudo o que é chamado hoje de memória não é, portanto, memória, mas já história. Tudo o que é chamado de clarão de memória é a finalização e seu desaparecimento no fogo da história. A necessidade de memória é uma necessidade da história.

Sem dúvida é impossível não se precisar dessa palavra. Aceitemos isso, mas com a consciência clara da diferença entre memória verdadeira, hoje abrigada no gesto e no hábito, nos oficios onde se transmitem os saberes do silêncio, nos saberes do corpo, as memórias de impregnação e os saberes reflexos e a memória transformada por sua passagem em história, que é quase o contrário: voluntária e deliberada, vivida como um dever e não mais espontânea: psicológica, individual e subjetiva e não mais social, coletiva, globalizante. Da primeira, imediata, à segunda, indireta, o que aconteceu? Pode-se apreender o que aconteceu, no ponto de chegada da metamorfose contemporânea. ${ }^{75}$

Assim surge a distinção entre a "história construída" e a "memória vivida" que estabeleceu marcos de uma nova abordagem capaz de reconstruir o passado do Estado Nacional Francês. Ampliando consideravelmente o conceito, Nora introduziu principalmente a memória nacional cuja construção é feita sistematicamente a partir de uma série de instituições, da escola aos arquivos, passando pelas festas e pelos monumentos de comemoração.

Com isso podemos dizer que nos últimos 40 anos, pesquisadores passam a questionar a forma, de certo modo arbitrária, pela qual a história trabalha e ordena os fatos e eventos passados. Representações ou memórias coletivas tornam-se parte do conjunto histórico, como uma nova alternativa para compreender o passado. Com isso os fatos passados são examinados de outra forma, analisando e avaliando os envolvidos daquele contexto.

Nessa direção, a leitura de Pollak ajudou a compreender a ligação entre memória e identidade social mais especificamente no âmbito das histórias de vida, ou daquilo que hoje, como nova área de pesquisa, se chama de história oral. Pollak afirmou:

\footnotetext{
${ }^{75}$ NORA, P. Entre memória e história: a problemática dos lugares. In: Projeto história, $\mathrm{n}^{\mathrm{o}} 10$. São Paulo, PUC-SP, dezembro de 1993, p. 14.
} 
A memória é seletiva. Nem tudo fica gravado. Nem tudo fica registrado. A memória é em parte herdada, não se refere apenas a vida física da pessoa. A memória também sofre flutuações, que são função do momento em que ela é articulada, em que ela está sendo expressa. As preocupações do momento constituem um elemento de estruturação da memória. ${ }^{76}$

O passado, portanto, só pode ser recuperado pelo presente por meio de processos de interação social. Sua compreensão e sua significação são compostas de uma rede complexa, em que o contato entre os indivíduos, em determinados contextos sociais, trazem o passado para o presente. "O conceito de memória, portanto, nos permite entrelaçar passado e presente, por um lado, ultrapassar a antinomia teórica clássica entre indivíduo e sociedade, por outro".77

Essas idéias são potencializadas no trabalho de Michael Pollak que em seu artigo "Memória esquecimento, silêncio"78 aponta a existência de uma memória em disputa e um papel para a história oral nesse campo:

Ao privilegiar a análise dos excluídos, dos marginalizados e das minorias, a história oral ressaltou a importância de memórias subterrâneas que, como parte integrante das culturas minoritárias e dominadas, se opõem à "Memória oficial", no caso a memória nacional. Num primeiro momento, essa abordagem faz da empatia com os grupos dominados estudados uma regra metodológica e reabilita a periferia e a marginalidade. Ao contrário de Maurice Halbwachs, ela acentua o caráter destruidor, uniformizador e opressor da memória coletiva nacional. Por outro lado, essas memórias subterrâneas que prosseguem seu trabalho de subversão no silêncio e de maneira quase imperceptível afloram em momentos de crise em sobressaltos bruscos e exacerbados. A memória entra em disputa. Os objetos de pesquisa são escolhidos de preferência onde existe conflito e competição entre memórias concorrentes. ${ }^{79}$

\footnotetext{
${ }^{76}$ POLLAK, Op. Cit., 1992, p. 204.

${ }^{77}$ SANTOS, M. S. História e Memória: o caso do Ferrugem. In: Revista Brasileira de história, vol.23, $\mathrm{n}^{\mathrm{0}}$ 46. São Paulo: 2003, disponível em: http://www.scielo.br/scielo.php?script=sci_arttext\&pid=S010201882003000200012 , acessado em 10/01/2007.

${ }^{78}$ POLLAK, M. Memória esquecimento, silêncio. In: Estudos Históricos, Rio de Janeiro, vol. 2, n. 3, 1989, p. 3-15.

${ }^{79}$ SANTOS, M. S. Op. Cit. 2003.
} 
Pollak é pesquisador ligado ao Instituto de História do Tempo Presente por isso defende uma história política, mas, mais que isso, promove uma ligação entre os pensadores que se detiveram a refletir sobre memória e a produção da história oral. Nesse mesmo artigo define memória silenciada como sendo aquela que por motivos politicos ou sociais ficou submersa por algum tempo, normalmente esse tipo de memória faz referência ao discurso de minorias que resistem ao “enquadramento da memória" realizado pelos que detêm o poder político e a força. Nesse sentido, ele lembra que lapsos não são invonlutários e que, muitas vezes, são a única forma de sobrevivência de uma determinada coletividade.

Entra-se, assim, em contato com outra importante questão de seus estudos: o esquecimento. Existe o esquecimento da história que organiza e classifica o que deve ou não ser lembrado, estudado, eternizado, de acordo com as relações de poder estabelecidas em uma sociedade. E existe também o esquecimento vivido por uma pessoa, que faz com que cada um consiga fazer seleções do que importa ou não de suas próprias vivências.

O conceito de esquecimento ganha relevância ao se refletir sobre a questão da seletividade da memória. Se nos damos conta de que, além de ser seletiva, a memória envolve o esquecimento, podemos compreender melhor a falta de controle que temos sobre ela, pois o que lembramos e esquecemos não é resultado apenas de nossas intenções e desejos declarados. Nós nos lembramos de detalhes aparentemente sem importância e esquecemos de faces, nomes e lugares que seriam fundamentais para nós. O esquecimento de experiências traumáticas pode acontecer independentemente de nossas vontades.

O que é preciso compreender é que indivíduos não armazenam uma totalidade de experiências passadas. Podemos dizer, portanto, que estamos sempre reconstituindo o passado a partir do legado que o passado deixou em nós e que o balanço entre as determinações do passado e do presente não é jamais dado a priori. ${ }^{80}$

\footnotetext{
${ }^{80}$ SANTOS, M. S. A luta da memória contra o esquecimento. In: Síntese Nova Fase 25, n. 82, 1998, pp. 351-368.
} 
A memória está presente em nós, no entanto podemos fazer uso de objetos externos como atalhos para se chegar a algumas lembranças. Ao lado desses "objetos biográficos" é mais fácil narrar uma história, pois "guardam" a memória e "fazem" lembrar das mais diversas maneiras.

A memória também traz indicações de rupturas, no diálogo entre passado e presente. Essas descontinuidades, rupturas e esquecimentos mudam o registro do passado, fogem ao controle dos que registraram o acontecido, tornando a história uma narrativa intersubjetiva.

Memória: um debate contemporâneo

Contemporaneamente, podemos apontar alguns desdobramentos do debate sobre memória. O primeiro e mais importante, ao menos para os historiadores, é o sobre diferenças entre história e memória na historiografia. Outro, mais particular, entretanto com grande relevância para esse trabalho, é o que envolve a prática da história oral e reflete sobre o papel dos narradores ao estabelecer suas memórias por meio de histórias de vida. Por fim, o mais atual e volumoso de todos esses debates, acontece em torno da noção de memória na pós-modernidade, que se vincula às discussões da memória a questão da identidade.

Nos debates recentes e mais gerais sobre memória, há a preocupação com os processos históricos vistos a partir de uma perspectiva ampla, mas também, procura-se compreender o que há de subjacente nas transformações sociais, ou seja, quais são as afetividades, o foro intimo daqueles que as produzem ou são submetidos aos seus efeitos. ${ }^{81}$ Existe uma crescente revalorização da

\footnotetext{
${ }^{81}$ BRESCIANI, S. e NAXARA, M. (orgs.) Memória e (res)sentimento: indagações sobre uma questão sensível.Campinas. Editora da Unicamp, 2001.
} 
memória, seu direito e seu dever são reivindicados por diferentes grupos sociais e políticos. Jacy Alves de Seixas aponta que, na historiografia, esse movimento tem convivido com uma ordem inversa, que é a falta de reflexão sobre o fenômeno. A autora concebe a memória como ferramenta analítica e, dentre os vários usos que se pode fazer dela e de suas relações com a história, a questiona como um instrumento político e como elemento amalgamador de identidades e de relações sociais. É algo que, unindo passado e presente, move as ações sociais positivamente em busca de um fim, de sua realização no futuro.

Outra grande demarcação apresentada diz respeito às diferentes formas de lembrar em que se evocam as memórias voluntárias - que obedecem à nossa vontade - ou involuntárias - que surgem sem serem evocadas. Sobre isso, salienta-se que é impossível determinar que um trabalho utilizou-se de uma ou de outra, na maioria das vezes elas se mesclam. Exemplo disso é que em uma situação de entrevista o entrevistado interrompeu suas narração para falar que não sabia como estava contando aquelas coisas, que não queria lembrar daquele evento. Mas lembrou. Assim, pode-se dizer que, majoritariamente, este trabalho lidou com memórias voluntárias, ou melhor, com memórias que foram resultado da intenção deliberada daqueles que narravam suas lembranças. Mas nem sempre.

Cabe aqui pontuar uma outra distinção, independente de serem voluntárias ou não, as memórias narradas, no momento da entrevista, foram provocadas. Responderam a um estímulo de uma pesquisa "externa" e se constituíram na relação entre dois sujeitos. Além disso, mesmo sendo narrativas construídas sobre o passado, não foram capazes de dar conta do que aconteceu exatamente. Memórias são falhas, porque têm como referência perspectivas sempre parciais (não arbitrárias) de um acontecimento do passado. As vontades do presente têm um impacto no que rememoramos. ${ }^{82}$ Isso não significa que

\footnotetext{
${ }^{82}$ HUYSSEN, A. Seduzidos pela memória: arquitetura, monumentos, mídia. Rio de Janeiro: Aeroplano Editora, 2004, p.69.
} 
a rememoração seja incompleta ou equivocada, mas sim que gera documentos diferenciados.

Com isso, há alguns elementos para entender o porquê desse interesse tão grande pela memória nas Ciências Sociais. Sem dúvida, lida-se com a memória porque ela pode dizer quem se é. Mesmo cientes de suas limitações, acredita-se poder fazer dela uma forma de saber para a produção de conhecimento sobre nós mesmos.

Recentemente, parte-se do pressuposto que as fronteiras entre história e memória são intercambiáveis, por isso faz-se necessário observar que a memória é formada por narrativas do presente, ao mesmo tempo em que a história é um conjunto de experiências que se sedimentaram ao longo do tempo. Memória e história são seleções. De acordo com Santos:

As definições de história e memória, portanto, lidam com fronteiras tênues, e gostaria de defender aqui a visão de que tanto devemos atribuir sentido ao passado, como procurar apreender o sentido atribuído a ele, e que estas duas abordagens devem ser consideradas simultaneamente na nossa tarefa de lidar com o passado, embora tenhamos claro que história e memória nem sempre sejam complementares. ${ }^{83}$

Ao contrário disso, pode-se dizer que a relação entre história e memória é conflituosa e concorrente "porque nem sempre a história consegue acreditar na memória, e a memória desconfia de uma reconstituição que não coloque em seu centro os direitos da lembrança (direitos de vida, de justiça, de subjetividade)". ${ }^{84}$

Desses desdobramentos e estudos mais recentes sobre o conceito de memória, quero destacar aqui os que envolvem o fazer da história oral. Pois como dito, a história oral é resultado de um processo interativo em que por meio de entrevistas é possível fazer com que as experiências pessoais venham à tona e possam ser registradas.

\footnotetext{
${ }^{83}$ SANTOS, M. S. Op Cit. 2003.

${ }^{84}$ SARLO, B. Op. Cit., 2007, p. 9.
} 
O uso de fontes orais, entretanto, não é nada novo, assim como foi apontado em uma entrevista com Marieta Ferreira de Moraes para a revista ComCiência:

"Desejoso de saber, interrogo". A frase do grego Heródoto, autor daquele que é considerado o primeiro trabalho histórico da civilização ocidental, demonstra que a utilização de fontes orais como meio para se escrever história não é fenômeno recente. Falar do estudo da história, segundo o historiador Paulo Miceli, é falar da origem prática da memória, do testemunho, da pergunta e da resposta, que é muito antiga e que se estende até os dias atuais. Segundo ele, a recorrência a relatos orais para a compreensão da história foi historicamente utilizada por vários autores e de diferentes maneiras: "No século XVI, temos Bernardino de Sahagún, que quis entender os povos conquistados pelos espanhóis e os entrevistou", afirma. Miceli cita ainda outros estudos que tiveram caráter semelhante, como o de Michelet, que fez uma pesquisa para saber a opinião que os franceses tinham sobre a sua própria revolução, no século XVIII. ${ }^{85}$

Vale observar que nem todo trabalho com fontes orais é um trabalho de história oral. Por isso, Meihy denomina o trabalho com entrevistas, que tem suas principais preocupações derivadas do diálogo estabelecido com os entrevistados, de "moderna história oral"86, caracterizando-o como um novo campo de investigação. De qualquer maneira a história oral vem se preocupando com o estudo sobre a memória.

Em vista de toda a trajetória percorrida pelo conceito de memória pode-se dizer que a relação entre história e memória tem sido re-significada.

O maior valor da história oral, para pensadores como Thompson que defendem sua relevância, está em consolidar que a oralidade dá vida e energia às narrativas, permitindo a trama de uma

\footnotetext{
${ }^{85}$ Memória é matéria prima do trabalho do historiador. In: ComCiência, 2003. Disponível em http://www.comciencia.br/reportagens/memoria/04.shtml, acessado em 10/01/2007.

${ }^{86}$ Esse termo é também usado como forma de diferenciar a história oral contemporânea, da história escrita a partir de fontes orais, praticada desde a antiguidade clássica. MEIHY, J. C. S. B. História oral: um locus disciplinar federativo. In: MEIHY (org). (Re)introduzindo a história oral no Brasil. São Paulo: Xamã, 1996, pp. 48-55.
} 
história. A história oral flexibiliza ainda mais o uso das fontes, pluralizando e democratizando a escrita da história.

Segundo Joutard é, portanto, primeiro pela investigação oral que as memórias coletivas dos grupos são apreendidas. Elas aparecem quando as mesmas lembranças, vividas ou transmitidas, voltam de maneira repetitiva e quando elas são apresentadas como propriedade especifica da comunidade.

A maior parte do tempo essa memória decepciona o historiador: ela é feita de vida cotidiana, onde a inundação, a geada precoce ou tardia, o incêndio da granja deixaram mais traços do que a Revolução Francesa, ou mesmo os 'maquis' da Segunda Guerra Mundial. Ela idealiza o passado, que se torna o 'belo passado', apagando as tensões sociais e as lutas de clã, numa visão unanimista e pacífica. ${ }^{87}$

O autor afirma que uma comunidade baseia sua legitimidade e sua identidade na recordação histórica. Nesse caso, a memória é terrivelmente simplificadora: se organiza em torno de um acontecimento fundador. Os fatos anteriores ou posteriores vão sendo assimilados ou esquecidos. Quando são memorizados é por analogia, repetição e confirmação do acontecimento fundador. O esquecimento é constitutivo da memória: mas esse esquecimento pode ser vontade de limitar-se ao essencial ou ocultação.

A memória oral se alimenta de toda uma cultura escrita e iconográfica, de que se tem maior ou menor consciência. Não é pertinente a oposição entre uma memória coletiva que seria popular e oral e uma memória histórica, erudita e escrita. Ao se concordar com a idéia de Halbwachs de que a lembrança não se mantém sem uma rede de sociabilidade dinâmica, é importante lembrar que essas redes não se limitam a instituições reconhecidas, como as escolas, mas se estabelecem de forma livre no cotidiano das pessoas.

Por fim, abre-se o debate da memória na pós-modernidade, o qual normalmente relaciona a memória com um produto a ser consumido ou com sua midiatização. De modo geral, a perda da

\footnotetext{
${ }^{87}$ JOUTARD, P. Verberte: Memória Coletiva, pp. 526-528. In: BURGUIÈRE, A. Dicionário das ciências históricas. São Paulo: Imago, 1993, p. 567.
} 
memória é uma das grandes ameaças do mundo moderno. O excesso da memória como forma de descartar, consumir, esquecer, em meio ao excesso de informações é o foco das atenções dos estudos do crítico alemão pós-frankfurtiano Andreas Huyssen,88 da crítica literária argentina Beatriz Sarlo, ${ }^{89}$ e do sociólogo inglês Anthony Giddens. ${ }^{90}$

\section{Narrativas: usos e práticas}

A matéria-prima para a constituição de uma narrativa é a experiência memorizada, que pode ser reinterpretada, reinventada e contada. A narrativa é a forma pela qual se tem acesso às memórias pessoais. Nesse sentido, os conceitos de memória e narrativa são inseparáveis.

Antes de mais nada, é relevante fazer uma distinção entre três tipos de narrativas: a ficcional, a historiográfica e a cotidiana, tal distinção se faz necessária mesmo com a ressalva de que as três narrativas se relacionam com a realidade de algum modo, de acordo com aquilo a que querem se referir especificamente.

Sobre a narrativa de ficção pode-se afirmar que:

... só é "fictícia" sob certo aspecto. Mas, por outro lado, dela não se pode dizer que não "represente" uma certa realidade, ou, o que é mais importante, que não possa manter com a realidade uma relação de "verdade". De fato a narrativa de ficção estabelece com a realidade uma relação criativa que articula suas configurações possiveis, e o relato supostamente "fictício" se constrói como tal apoiando-se numa realidade prévia, num campo da experiência cultural vivida. ${ }^{91}$

Valeria também salientar que muitas narrativas hoje consideradas "fictícias" já foram caracterizadas de outra forma, em outros momentos históricos. Isso porque os critérios para considerar uma narrativa ficcional ou não, mudam com o tempo. De qualquer

\footnotetext{
${ }^{88}$ HUYSSEN, A. Op. Cit.

${ }^{89}$ SARLO, B. Cenas da vida pós-moderna: intelectuais, arte e vídeo-cultura na Argentina. Rio de Janeiro, Ed. UFRJ, 1997; e SARLO, Op. Cit, 2007.

${ }^{90}$ GIDDENS, A. As conseqüências da modernidade. São Paulo, Ed. UNESP, 1991 e GIDDENS, A. Modernidade e identidade. Rio de Janeiro: Ed. Jorge Zahar, 2002.

${ }^{91}$ BARBOSA, M. F. Experiência e narrativa. Salvador: EDUFBA, 2003, p. 15.
} 
maneira, o segundo tipo de narrativa que pode ser destacado é a historiográfica, sobre a qual:

... podemos dizer que a relação que se procura estabelecer com a realidade neste caso é uma representação verdadeira, científica, da realidade. O que se quer é descobrir como os fatos realmente aconteceram. Mas essa pretensão à representação verdadeira, ao menos a princípio, é crítica: sabe-se apoiada nos rigores e nas limitações do método científico, e não descarta seu possivel caráter provisório. ${ }^{92}$

A distinção entre esses dois tipos de narrativa ganhou centralidade nas discussões do americano Hayden White. A esse respeito o historiador escreveu muitos textos, defendendo que quanto à representação factual "há muitas histórias que poderiam passar por romance, e muitos romances que poderiam passar por histórias", se consideradas puramente em termos formais, posto que ambas desejam "oferecer uma imagem verbal da 'realidade". 93

Por fim, cabe apontar uma definição do que seria a narrativa cotidiana, que vem ganhando adeptos em recentes pesquisas, como na área de história oral.

... a narrativa cotidiana, a narração do dia-a-dia, possui um modo de relação com a realidade que poderia ser confundido com aquele característico da narração historiográfica. Isso porque a narrativa, na vida cotidiana, também procura relacionar-se com o real enquanto "representação" verdadeira. (...) A diferença essencial é que a pretensão à verdade, na narrativa cotidiana é uma relação imanente e interna, é um fator essencial e constitutivo do próprio ato de narrar, da própria narração. A razão de ser primeira dos relatos do dia-adia é serem eles verdadeiros (venha isso a se confirmar objetivamente ou não), e disso resulta seu poder de construir o que é "real" na experiência de um indivíduo ou de uma comunidade. ${ }^{94}$

Essa separação é bastante didática, pois é preciso pensar na dificuldade e arbitrariedade de se delinear fronteiras entre esses gêneros de narrativa. Digo didático, pois estabelece uma ordem de

\footnotetext{
${ }^{92}$ Idem, p. 15-16.

${ }^{93}$ WHITE, H. Trópicos do discurso: ensaios sobre a crítica da cultura. São Paulo: EDUSP, 2001, p. 137138.

${ }^{94}$ BARBOSA, Op. Cit., p. 16.
} 
distinção classificatória que pode ser questionada, pois segundo Foucault:

Quando instauramos uma classificação refletida (...) qual é, pois, o solo a partir do qual podemos estabelecê-lo com inteira certeza? Em que "tábua", segundo qual espaço de identidades, de similitudes, de analogias, adquirimos o hábito de distribuir tantas coisas diferentes e parecidas? (...) Nada mais tateante, nada mais empírico (ao menos na aparência) que a instauração de uma ordem sobre as coisas (...) de fato não há, mesmo para a mais ingênua experiência, nenhuma similitude, nenhuma distinção que não resulte de uma operação precisa e da aplicação de um critério prévio. Um "sistema dos elementos" - uma definição dos segmentos sobre os quais poderão aparecer as semelhanças e as diferenças, os tipos de variação de que esses segmentos poderão ser afetados, o limiar, em fim, acima do qual haverá diferença e abaixo do qual haverá similitude - é indispensável para o estabelecimento da mais simples ordem. ${ }^{95}$

Então, ao se buscar uma ordem para esse texto, e sabendo que as classificações são construções, fiz a escolha de uma delas, ao apresentar as definições acima, para seguir o caminho desse trabalho.

Ainda, como mostrou James Clifford esta construção enfrenta a escolha de o que falar sobre o trabalho de campo e sobre as teorias estudadas. De modo que, normalmente, reflexões sobre o campo ficam restritas às introduções metodológicas ou notas de rodapé, nas quais se quantificam o tempo de convivência com o grupo pesquisado, a forma como o pesquisador chegou ao campo e como deu início a sua pesquisa. 96 Outras reflexões, elaboradas por Silva, do campo da antropologia, podem ser transpostas para o presente trabalho.

Os dados da experiência do antropólogo, principalmente aqueles considerados mais "subjetivos" (ou os "timbres e entonações" das vozes "informantes"), quando expostos, aparecem com cautela na escrita etnográfica, para não se correr o risco de tornar a etnografia uma experiência única e singular, ou passivel de ser confundida com uma "obra de literatura" propriamente dita. ${ }^{97}$

\footnotetext{
${ }^{95}$ FOUCAULT, M. As palavras e as coisas: uma arqueologia das ciências humanas. São Paulo: Martins Fontes, 1985, p.9.

${ }^{96}$ CLIFFORD, J. The predicament of culture. Harvard: Harvard University Press, 1988.

${ }^{97}$ SILVA, Op. Cit, p. 120.
} 
No debate contemporâneo, se apresentam duas principais linhas interpretativas sobre narrativas, que, por vezes, se contrapõem: uma que privilegia a relação da narrativa com a experiência, e a outra que reflete como se configuram o uso da narrativa na história e as narrativas históricas.

Sobre a primeira é preciso dizer que o ato de narrar é considerado um rememorar da experiência, um trabalho de memória. Portanto, é um desafio colocar em palavras um sentimento, um pensamento, ou uma vivência. Como expressou Daniel, ao tentar explicar seu trabalho nas cirandas 98 e nas escolas itinerantes"9: "Como é que vou explicar?... Estou um pouco nervoso e me fogem as palavras..."

Sendo assim, o primeiro desafio para o entrevistado é querer narrar, ou seja, reconhecer que sua história é importante, que sua experiência é digna de ser contada e se propor esse exercício. O segundo é conseguir narrar: fazer a seleção de palavras que possam traduzir seu cotidiano e contar sua história de vida.

Esses desafios são potencializados ao se imaginar as situações de exclusão e desvalorização pelas quais tais pessoas passaram ao longo de suas vidas. Portanto, do primeiro contato ao início da gravação de uma entrevista, estabelece-se um momento de convencimento, mediação e intervenção do pesquisador.

Mesmo aceito o desafio, em alguns momentos, para ganhar tempo na busca por palavras a serem ditas, organizar seus pensamentos e responder uma pergunta, o entrevistado usa de artificios que por vezes aparecem em sua narrativa, como no caso de Aquiles, quando fala: "Não sei dizer um melhor e um pior momento da minha

\footnotetext{
${ }^{98}$ Cirandas são classes informais de ensino infantil organizadas nos acampamentos e assentamentos, escolas e marchas do MST.

${ }^{99}$ Escola itinerante é o nome dado às escolas (reconhecidas pelo estado ou não) de ensino fundamental que acompanham os acampamentos formando suas crianças onde quer que estejam, é comum ouvir membros do MST dizerem que essa escola vai onde a criança for; nos estados do Rio Grande do Sul, Paraná e Santa Catarina é integrada a rede pública estadual de educação. Sobre isso ver: TAKAU Jr, Iokisa. Escola itinerante: escola, Estado e MST no espaço do acampamento. Trabalho de Graduação. São Paulo: DG-FFLCH-USP, 2005.
} 
vida... ... Minha voz está falhando... acho que por causa da tosse... Ah... tem assim! Tem uns três... e já sei um para falar!"

De modo geral, a dificuldade é reconhecer uma experiência narrável, cabe lembrar uma reflexão tecida por Benjamin e retomada por Agamben nas seguintes palavras:

Benjamin que já em 1933 havia diagnosticado com precisão esta "pobreza de experiência", indicava suas causas na catástrofe da guerra mundial, de cujos campos de batalha "a gente voltava emudecida... não mais rica, porém mais pobre de experiência partilháveis... visto que as experiências jamais receberão desmentido tão radical quanto as experiências estratégicas na guerra de posição, as experiências econômicas na inflação, as experiências corpóreas na fome, as experiências morais no despotismo. (...)" Porém, nós hoje sabemos que, para destruição da experiência, uma catástrofe não é de modo algum necessária, e que a pacifica existência cotidiana em uma grande cidade é, para esse fim, perfeitamente suficiente. (...) O homem moderno volta para casa à noitinha extenuado por uma mixórdia de eventos divertidos ou maçantes, banais ou insólitos, agradáveis ou atrozes -, entretanto nenhum deles se tornou experiência. ${ }^{100}$

Nesse sentido, faz-se uma leitura ampla sobre o conteúdo das entrevistas apontando que falam muito mais sobre suas vidas no MST que sobre suas experiências anteriores, mesmo que essas tenham tomado mais tempo de suas vivências. Entretanto, pode-se dizer que essa vivência anterior não se tornou experiência narrável. Ela está mais ligada a uma situação de desumanização com a qual essas pessoas não mais querem se identificar.

Nas narrativas cotidianas, esse tempo vivido do "antes" aparece re-significado pela experiência do "depois". Os narradores fazem uso dessas lembranças numa tentativa de justificar seu comportamento no presente, destacando o quanto sua opção de entrar no Movimento fez com que sua vida mudasse, apresentando a vida anterior de exclusão como forma de participar da mesma comunidade afetiva dos sem-terra em luta.

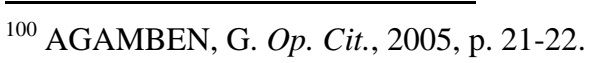


Outra leitura possivel é que os colaboradores, narrando sua situação de antes a partir do momento que foram re-significadas, transformam o que era inenarrável em força de suas narrativas, conseguindo partilhá-las. Assim, liga-se o conceito de experiência e narrativa. Ou seja, podemos dizer que a experiência se torna "fonte" da narração. O que podemos observar nas palavras de Wanderléia ao fazer um balanço da sua vida:

Tudo que falei é de coração. É o que aconteceu comigo. Não foi com fulano ou com sicrano. Foi comigo! Foram fatos da minha vida! O que tenho para falar é isso aí... Mas não me canso de dizer que eu me sinto GENTE no Movimento. Me sinto uma pessoa importante.

Uma afirmação como essa coloca em evidência que a experiência de vida do entrevistado é o que legitima, para ele mesmo, sua entrevista. Wanderléia mostra que hoje entende o quão importante foi experimentar cada um dos eventos que narrou. Dá a dimensão humana das conquistas que realizou, conferindo um sentido a sua experiência de exclusão e de trauma. Nessa mesma direção, quero lembrar as palavras de Simone Weil, sobre "o desenraizamento operário":

O futuro não nos traz nada, não nos dá nada; nós é que, para construí-lo, devemos dar-lhe tudo, dar-lhe nossa própria vida. Mas, para dar, é preciso ter, e não temos outra vida, outra seiva, a não ser os tesouros herdados do passado e digeridos, assimilados, e recriados por nós. ${ }^{101}$

Assim essas histórias de vida são o que de mais precioso essas pessoas podem dar, pois é a única coisa que possuem: suas vidas, suas experiências, suas criações. Com isso, é preciso entender que narrar é um ato de cuidado e generosidade.

Nessa linha de valorização da experiência trabalharam e trabalham os pensadores de diversas áreas do conhecimento como: Benjamin, Agamben, Weil, Matos e Bosi. Mas como dissemos há uma outra ponta para esse debate.

\footnotetext{
${ }^{101}$ WEIL, S. A condição operária e outros estudos sobre a opressão. Rio de Janeiro: Paz e Terra, 1996, p. 418.
} 
É preciso lembrar que por muito tempo a narrativa cotidiana foi também a fonte para a escrita da história, mas que isso mudou em tempos que a história se transformou em Ciência. Segundo Arendt:

$\mathrm{Na}$ época moderna a história emergiu como algo que jamais fora antes. Ela não mais compôs-se das façanhas e sofrimento dos homens e não contou mais a história de eventos que afetaram suas vidas. ${ }^{102}$

Assim passa-se um longo período em que a narrativa historiográfica é escrita sem apoio da narrativa cotidiana, pois "a narração foi oprimida juntamente com a história dos oprimidos. A modernização na exploração dos homens é simultânea às transformações científicas e ao declínio da arte de narrar". ${ }^{103}$

Mais recentemente, a construção historiográfica passou novamente a se utilizar das narrativas cotidianas para com elas reforçar a própria historiografia. Assim, com o pretexto de democratizar a história, historiadores utilizam as narrativas na construção de seus discursos, como forma de confirmar suas teorias previamente estabelecidas.

Nesse momento, faz-se necessária a distinção entre o uso da narrativa na história e os debates sobre narrativa histórica. Frente a isso se colocam discussões sobre a possibilidade da produção historiográfica assumir ou não uma forma narrativa, ou melhor, se o trabalho dos historiadores é ou não a escrita de narrativas. Essa é uma longa discussão que mereceria aprofundamentos. ${ }^{104}$ Todavia, mais que isso, interessa um desdobramento dessa discussão que remete aos tipos de narrativas a serem escritas. Esse tema se torna relevante, na medida em que os historiadores perceberam que com seu trabalho não reproduzem o acontecido e sim representam um ponto de vista particular, por mais negociado que seja. Sendo assim os "narradores

\footnotetext{
${ }^{102}$ ARENDT, H. Entre o passado e o futuro. São Paulo: Perspectiva, 1979, p. 89.

${ }^{103}$ Comentário realizado por Matos a respeito das afirmações de Benjamin. MATOS, O. Narrativa: metáfora e liberdade. In: História Oral. São Paulo: $\mathrm{N}^{0}$ 4, junho de 2001, pp. 9-24, p.10.

${ }^{104}$ Um balanço é feito por BURKE no artigo A história dos acontecimentos e o renascimento da narrativa. In: BURKE, Op. Cit., 1992.
} 
históricos"105 devem tornar-se visiveis em suas narrativas, de modo a afastar a onisciência dos textos que produzem.

White foi um dos historiadores que levou a frente esse debate, distinguindo a existência de quatro tipos de narrativas historiográficas: tragédia, comédia, sátira e romance.

Por essa origem comum é que White, ao refletir sobre as proximidades dessas narrativas ficcionais e historiográficas, chegou a acusar os historiadores de negligenciar as reflexões literárias de sua época e permanecer no "realismo" literário. Para ele existem fortes relações entre literatura e história e o texto histórico pode ser lido como um “artefato literário". A esse respeito, afirma:

... é difícil obter uma história objetiva de uma disciplina erudita porque, se o historiador a pratica ele mesmo, provavelmente será adepto de uma ou outra de suas seitas e, por conseguinte, tendencioso; e, senão a pratica, é improvável que tenha a perícia necessária para distinguir entre os acontecimentos significativos e os não significativos de sua área. 106

Peter Burke em seu balanço "A escrita da história: novas perspectivas" complementa apontando a existência de ao menos quatro formas de narrativas historiográficas: a micronarrativa, a narrativa de frente para trás, as que se movimentam para frente e para trás e aquela que apresenta pontos de vistas múltiplos. ${ }^{107}$

\section{Uma possibilidade de diálogo}

A intenção de mostrar essas duas linhas (narrativa/experiência e narrativa/história) foi para que agora pudesse apresentar a existência de uma terceira que pode ser uma ponte para o diálogo entre essas primeiras. Uma possibilidade de mudar o modo com que vem sendo escrita a historiografia, ou seja, não mais colocar a narrativa cotidiana como apoio para escrever a história, e sim colocá-la como forma de escrever a história.

\footnotetext{
105 Termo utilizado por Burke, que me parece bastante apropriado.

${ }^{106}$ WHITE, Op. Cit., 2001, p. 97.

${ }^{107}$ BURKE, Op. Cit., 1992, p. 347.
} 
Nesse sentido, é preciso tomar a discussão do discurso como ação, o que pode ajudar a dissolver essa oposição e unir essas duas pontas do debate.

Uma das facetas desse debate são as discussões sobre o discurso como ação, emblemadas por Foucault e sobre a desconstrução, representadas pelos trabalhos de Derrida. A experiência então é tratada como a prática discursiva, posto que o próprio sujeito se constrói por meio do discurso.

Discurso, nesse sentido, é acontecimento e narrativa, é um conjunto de ações no tempo. Cada narrativa tem uma especificidade, que está ligada ao tipo de experiência que precisa ser narrada para que o sujeito se forme de uma determinada maneira.

Assim, é dificil separar da narrativa de ficção a narrativa cotidiana e historiográfica, pois todas elas fazem uso de estruturas narrativas, segundo Matos: de tragédia ou de fábula.

A tragédia e a fábula são formas de narração que transformam a vida em um trabalho permanente de reelaboração emotiva, de repensamento do acontecido. A narração cria, assim, espaços de liberdade, é força hermenêutica transformadora. ${ }^{108}$

A maior parte das narrativas desse trabalho são trágicas, mas isso não elimina a existência da ironia, que consegue apresentar uma autocrítica em relação ao que acabou de ser dito. Isso aparece na entrevista de Aquiles, quando ele mesmo, depois de um longo discurso, compara sua fala a um sermão ao falar: "Amém!"

É importante pensar que quem narra tem um objetivo. Quer explicar algo para si e se constitui nesse ato de narrar. Narração é uma ação concreta, pois é o ato de produzir um discurso que conforma o mundo dessas pessoas. A narrativa tem um poder e empodera seu criador. Os narradores querem também testemunhar sobre a situação de dor e de extrema violência, pois precisam recompor o seu "eu" e a idéia de justiça, após ter sobrevivido à injustiça.

${ }^{108}$ MATOS, Op. Cit., p.15. 
O testemunho dos que se salvaram é a "matéria-prima" de seus leitores ou ouvinte, que devem fazer algo com o que lhes é comunicado e que, justamente porque conseguiu ser comunicado, é só uma versão incompleta. Os que se salvaram "não podem senão lembrar"... 109

A exemplo dessa construção do sujeito no ato de narrar, podemos destacar a fala de Ana Paula:

Eu queria dizer que o Movimento Sem Terra cria vários momentos de formação. Uma entrevista dessas é um momento de formação. Dá para perceber a história do nosso povo. A história de cada um e cada uma não é diferente, está envolvido numa coisa só, muito bonita, a nossa organização. A luta de todos é igual, um só objetivo.

Ana Paula constrói uma identidade vinculada ao MST, como se a entrevista fosse um curso de formação. Seguindo a trilha de Foucault, pode-se afirmar que foi mesmo pois, ao narrar, Ana Paula foi se constituindo enquanto sujeito, dando significado a sua vida e se "formando".

Com isso a narrativa pode passar a ser o espaço da pesquisa, local de onde a pessoa faz suas associações e retrata seu espaço. A construção de um espaço (de onde se fala) possibilita a construção de um projeto com novos e maiores horizontes (ideal, sonho e realização idílica). Dessa maneira, tem-se que sair do plano das estruturas e levar em conta a narrativa (como as pessoas se expressam, se pensam e lêem seu mundo) para chegarmos ao significado daquelas palavras para os colaboradores de nossas pesquisas.

Mas afinal de contas, o que precisa ser explicado? Qual a função dessa narrativa? Uma primeira resposta pode apontar para a necessidade de superar a barreira da dor da exclusão, romper com a dignidade desfeita e com a destruição das crenças. É uma forma de essas pessoas retomarem sua dignidade e restabelecerem alguma crença e a possibilidade de viver. A narrativa, que tem como fonte a

${ }^{109}$ SARLO, Op. Cit., 2007, p. 35, citando reflexões de Agamben. 
experiência, cria o real e, ao mesmo tempo, o sujeito se cria no ato da narração, e se criando cria seu mundo.

Nessa pesquisa, as entrevistas não foram orientadas pela busca de uma cronologia. Frente a frente com o colaborador, o projeto era explicado. Tentando evitar impor uma temporalidade alheia a ele, não foram feitas perguntas como: Onde e quando você nasceu? ou Como foi sua infância?

As entrevistas sempre se iniciaram com o pedido de que a pessoa se apresentasse e a orientação de que se sentisse livre para contar suas experiências de vida mais marcantes. Tentava não me apresentar como "historiadora", ou falar que o trabalho era de "história", pois essas palavras, muitas vezes, servem como orientadoras de um discurso em tempo linear, o que não era o objetivo. A intenção era que as narrações fossem feitas de acordo com os tempos e escolhas dos próprios entrevistados, mesmo tendo em mente que a dinâmica da marcha era um limitador para um registro mais longo, ou para o desdobramento de encontros.

Após a pessoa se apresentar, o que variava entre segundos e muitos minutos, tentou-se acompanhar a narração, não impondo temas ou assuntos, mas retomando tópicos já mencionados. As entrevistas não seguiram um questionário fechado pré-estabelecido, foram entrevistas abertas, que mais se assemelharam a um diálogo entre alguém que tem muito a falar e alguém que tem muito a aprender.

Em poucos momentos foram feitas questões mais pontuais, necessárias para o entendimento de uma ou outra passagem, ou resultantes da curiosidade motivada pela conversa. Assim, o que se apresentou no texto é o resultado de um diálogo de uma historiadora com um narrador. A textualização da entrevista é o resultado dessa interação entre a lógica do entrevistado com o entrevistador.

Porque evitei fazer perguntas fechadas, muitas vezes fui questionada sobre meu papel na entrevista, como ocorreu com Ronaldo ao afirmar: "Estou falando, mas para o cabra chegar e falar assim fica dificil... Quando tem algumas perguntas fica mais fácil.” Entretanto, sem 
demora ele continuou. Sozinho, sem perguntas. Escolhendo por si só o rumo de sua história. Ronaldo não abriu mão da liberdade de escolher seu próprio caminho, o que a princípio parecia dificultar sua fala. Ele fez uso dessa liberdade também para ganhar tempo e elaborar sua narrativa.

Outro resultado desse procedimento é que se pode ver entrevistas com pequenas digressões, em que a narrativa "vai e volta", ou mesmo entrevistas com grandes descrições, ou explicações. Assim ocorre o que Bosi aponta como sendo distração, "um desvio do eixo e tração pelo qual somos puxados”, uma divagação, uma descontração do espírito. 110

A exemplo dessas seleções e construções pode-se destacar do conjunto de entrevistas apresentado, a fala de Ana Paula, que ao divagar sobre a história de sua mãe, se perde e se acha, demonstrando isso ao dizer: "E, para chegar nisso ela... ... ... Tá!..." "Tá” é a volta ao eixo narrativo, ao trilho de seu raciocínio, de seu trabalho de memorizar e narrar. Até que ela pode concluir "Bem bonita a história da minha mãe!"

Essa distração não é algo descolado da história de vida de Ana Paula, e por isso é parte integrante de sua narrativa cotidiana. O cotidiano na história, do qual nos falou Agnes Heller, poderia ser, aqui, ser evocado:

A vida cotidiana não está "fora" da história, mas no "centro" do acontecer histórico; é a verdadeira "essência" da substância social. (...) As grandes ações não cotidianas que são contadas nos livros de história partem da vida cotidiana e a ela retornam. Toda grande façanha histórica concreta torna-se particular e histórica precisamente graças a seu posterior efeito na cotidianidade. A vida cotidiana é a vida do indivíduo. ${ }^{111}$

No centro das preocupações estava o sujeito e a sua versão de como a vivência em comunidade altera sua vida. Assim, quis-se

\footnotetext{
${ }^{110}$ BOSI, Op cit. 2003, p. 40.

${ }^{111}$ HELLER, A. O Cotidiano e a história. Rio de Janeiro, Paz e Terra, 1985, p. 20. Ainda a esse respeito, vide LEFEBVRE, H. A Vida Cotidiana no Mundo Moderno. São Paulo, Ed. Ática, 1991.
} 
perceber como esse sujeito constrói sua própria história, e ainda, quais são os alicerces sobre os quais constrói suas opções. Nessa medida é que podemos afirmar que:

...a história oral implica numa construção histórica da experiência pessoal, que deve ser valorizada, exatamente porque representa a dimensão cotidiana do fazer histórico. ${ }^{112}$

Com os registros das narrativas realizado dessa forma teve-se acesso às escolhas feitas, aos conflitos, ou às divergências que aconteceram em nivel particular, e que acabam por se refletir nas identidades de seu grupo. Vale marcar as percepções negociadas entre entrevistador e entrevistado e os diálogos que se apresentam em meio à narrativa. Algo que vai além da situação de encontro e das falas presentes durante a entrevista, mas que abarca toda uma vivência conjunta, relações de amizade comuns, o que demonstra um envolvimento com o grupo e permite um diálogo mais fluido e de referências mínimas compartilhadas. Isso pode ser percebido em situações como a da entrevista de Elizandra, ao dizer: "Mas só que além de eu cumprir as atividades, tinha que fazer relatórios, leituras dirigidas... a Andrea, nossa companheira, que está com você nessa pesquisa também, acompanhou essa fase minha."

Muitas entrevistas finalizam com colocações como a de Ronaldo: "Eu acho que eu já falei quase tudo..." Ou seja, esses narradores têm consciência de que esse não é um ponto final, é um por enquanto. Essa frase carrega toda a incerteza que o recorte momentâneo tem. Naquele momento, mesmo perguntado se tinha algo mais a dizer, não foi capaz de pensar em nada que devesse ser dito, mas sabia que essa era uma decisão daquele momento, que sua história de vida não estava completa, mas "quase tudo" tinha sido falado. Esse era um fim provisório, que ele "achava" ser apropriado.

112 SANTOS, A. P. Ponto de vida, cidadania de mulheres faveladas. São Paulo, Ed. Loyola, 1996, pp. 1920. 


\section{Desdobramentos no campo da história oral}

Desse conjunto de reflexões tiram-se alguns desdobramentos para o campo prático da história oral. Pode-se pensar que essas tramas biográficas reinventam uma vida e como afirmou Bosi: "uma história de vida não é feita para ser arquivada ou guardada numa gaveta como coisa, mas existe para transformar a cidade [o local] onde ela floresceu". ${ }^{113}$ Essa função transformadora está expressa no conjunto das entrevistas que mostram engajamento e motivações. Além disso, segundo Ades: "a história oral não é apenas o recolhimento do testemunho pessoal, ela é uma maneira de resgatar 'as camadas da população excluídas da história". ${ }^{114}$ Há mais do que curiosidade científica no ato de dar a palavra a alguém. No mínimo, há a intenção da denúncia.

A entrevista convertida em narrativa escrita é estabelecida como documento para a história oral, um documento/narrativa produzido a partir de um processo teórico-metodológico. ${ }^{115}$

Refletir sobre documentos para a história oral implica em pensar a pós-modernidade e a liquidez do mundo contemporâneo que "documentos sólidos" talvez não consigam dar conta de explicar. Por isso, crescem as formas "alternativas" de documentação, como os documentários em vídeo e a própria história oral. Esses documentos em si têm uma carga de contemporaneidade, por serem produzidos por equipamentos modernos (câmeras e gravadores, por vezes, digitais), mas, mais que isso, são também "descontínuos", "auto-reflexivos"116 e "líquidos"117 como seu próprio tempo. Eles são subjetivos e não objetivos. São líquidos e não sólidos. Não contém uma verdade e uma explicação sobre o mundo, se moldam às diferentes situações.

\footnotetext{
${ }^{113}$ BOSI, Op. Cit, 2003, p. 69.

${ }^{114}$ ADES, C. Op. Cit. (resenha).

${ }^{115}$ MEIHY, J. C. S. B. Manual de história oral. São Paulo: Edições Loyola, 2005 e RIBEIRO, S. L. S. Procedimentos metodológicos. In: Processos de mudanças no MST: história de uma família cooperada. São Paulo: DH-FFLCH-USP, 2002, pp 26-40.

${ }^{116}$ GIDDENS, A. Op. Cit, 1991; GIDDENS, A. Op. Cit, 2002.

${ }^{117}$ BAUMAN, Z. Modernidade líquida. Rio de Janeiro: Jorge Zahar Ed., 2001.
} 
Nesse sentido, cabe lembrar as reflexões, realizadas desde a década de 70, pelo estadunidense James Hoopes:

$\ldots$ in the case of the oral document, the critical questions are more personal and subjective because of your involvement in creating the document. The consequent difficulty in interpreting the oral document can be both frustrating and excellent training. The problem is that, though an interview may contain lies, it is unlikely to contain the truth. The best that you can hope for is that the interviewee has told $a$ truth, the truth as it looks to him. Your crucial critical question, therefore, is not "how do I know that the interviewee has told the truth?" Rather, you should ask, "What do I know from the interviewee's words about his actual experience and about his perception of that experience? 118

Também que se pode relacionar essa fluidez com um processo de globalização, não só da economia e da política, mas também da história oral.119 Isso tem relação com a busca de novas formas de documentar e explicar o mundo (em todo o mundo). Daí a idéia das histórias de vida como um novo tipo de documento "moderno", não só porque gravado, mas por ter nele outras características, carregadas de modernidade (globalização, tecnologia, fragmentação, não verdade...).

É interessante ver que a história oral está crescendo sem lugar definido, seus principais pensadores são críticos literários, historiadores, antropólogos, sociólogos e isso pode fazer sentido junto com a discussão sobre o surgimento de uma área de estudos, (não um locus interdisciplinar, mas uma forma de produzir conhecimento diferente, a partir desses documentos diferentes), pois é um campo que tem crescido significativamente nos últimos anos. Daí advém o posicionamento de pensadores como Meihy que defendem que a história oral seja uma disciplina, com preocupações, procedimentos e teoria próprios. ${ }^{120}$

\footnotetext{
${ }^{118}$ HOOPES, J. Oral history: an introduction for students. Chapel Hill: The University of North Carolina Press, 1979, p. 123.

${ }^{119}$ Essa reflexão sobre o crescimento da história oral se desenvolveu durante minha participação no "2007 Oral History Semminar”, organizado pelo Columbia Oral History Office. Nesse seminário havia uma mesa para a discussão do que chamaram de "Oral History Movement” fazendo referência a seu desenvolvimento em vários países, como um movimento global.

${ }^{120}$ MEIHY, J. C. S. B. La radicalización de la historia oral. In: Palabras e silencios. Revista de la Asociación Internacional de Historia Oral. Nueva Época, vol 2, n. 1, junio 2003, pp. 33-45.
} 
Propõe-se, portanto, uma associação entre documento oficial/tradicional com um mundo sólido e de verdades objetivas e o documento/narrativa resultado do trabalho de história oral e da interação entre sujeitos, com um mundo mais fluido, mutável, múltiplo e líquido. Desdobrando essa questão é possível associar isto também com o tipo de identidade que se forja (elabora, esculpe). Ao assumir a "liquidez" do documento, pode-se enxergar numa mesma narração sobre uma experiência, muitas identidades, pois o "eu", não é uma entidade passiva, mas determina e é determinada pelas contingências. ${ }^{121}$

Nesse sentido, cabe uma critica aos trabalhos em história oral que em geral se preocuparam mais com a captação dessas subjetividades na situação da entrevista, que com a análise delas. De forma geral, os pesquisadores tendem a aprisionar $\mathrm{e}$ fechar possibilidades no momento em que se debruçam para interpretá-las. Mesmo percebendo isso, não se pode afirmar que esse trabalho conseguiu superar essa crítica, mesmo sendo isso uma de suas preocupações.

Sobre a situação de entrevista há pontos que merecem destaque. O primeiro é que mulheres e homens narram diferente: diferentes temas de diferentes modos. Sendo assim, é possivel afirmar que a narrativa tem gênero. Uma das grandes diferenças é que mulheres, incluem de maneira mais forte em seu narrar o tema família. Fazem críticas ao modo como se estrutura o movimento em torno da questão de gênero de maneira mais evidente. Enquanto os homens falam mais sobre a produção e sobre seus trabalhos de mobilização.

A historiadora Valerie Raleigh Yow lembra das diferenças entre masculino e feminino na narrativa. Segundo ela os homens são mais assertivos, e não têm medo de afirmar sua vocação ou força. Já mulheres costumam dar mais "voltas" para dizer algo sobre si mesmas, principalmente no que se refere ao reconhecimento de sua profissão e

${ }^{121}$ BHABHA, H. K. O local da cultura. Belo Horizonte: Ed. UFMG, 2001. 
suas habilidades. Yow exemplifica esses pontos a partir de seu trabalho. ${ }^{122}$

Ponto importante a ser estudado frente às marcas compartilhadas pelas narrativas é o uso de uma linguagem própria e a referência a uma trajetória comum. Marcas essas que caracterizam essa comunidade que pode ser evidenciadas ou apagadas de acordo com a postura assumida pelo pesquisador durante a realização da entrevista (papel da mediação e postura colaborativa) ou no momento da transposição do discurso oral para o escrito (transcriação).

É sabida a importância de se respeitar a imensa diversidade de modos de narrar, oriundos de diferentes vivências e jeitos de lembrar. Por outro lado, vê-se em uma mesma narrativa a presença de várias vozes. Inspirados nas reflexões de Mikhail Bakhtin ${ }^{123}$ quanto à polifonia que estas carregam, percebemos a riqueza das práticas na construção de memórias, identidades e subjetividades dos sem-terra.

Também as análises, presentes nesta tese, baseiam-se nas reflexões de Foucault sobre a noção de subjetividade, ao produzir uma história dos diferentes modos de subjetivação do ser humano, dividida em certas práticas objetivadoras, subjetivadoras e discursivas.

Assim, as perturbações e cobranças que rondam um historiador oral na hora da transposição do narrado para um texto escrito, são as mesmas do etnógrafo no momento de escrever seu texto. Preocupação expressa por Geertz da seguinte forma:

Afirmar [...] que escrever etnografia implica contar histórias, criar imagens, conceber simbolismos e desafiar figuras de linguagem, encontra comumente uma resistência, amiúde feroz, em virtude de uma confusão, que é endêmica no Ocidente pelo menos desde Platão, do imaginado com o imaginário, do ficcional com o falso, da compreensão de coisas com a invenção delas. A estranha idéia de que a realidade tem uma linguagem em que prefere ser descrita, de que sua própria natureza exige que falemos dela sem espalhafato pau é pau, pedra é pedra, rosa é rosa - sob pena de ilusão, invencionice e auto-enfeitiçamento, leva à idéia ainda mais

${ }^{122}$ YOW, V. R. Recording Oral History: a guide for the humanities and social sciences. Walnut Creek, CA: AltaMira Press, 2005, p. 301.

${ }^{123}$ BAKHTIN, M. Os gêneros do discurso. In: Estética da criação verbal. São Paulo: Martins Fontes, 1997. 
estranha de que, perdido o literalismo, também a realidade se perderá. ${ }^{124}$

A construção de todo texto é, portanto, um desafio para oralistas e etnógrafos, ainda mais visto que tradicionalmente a atenção desses pesquisadores não recai sobre "questões literárias". ${ }^{125}$ Com isso, pode-se dizer que as duas áreas estão caminhando lado a lado, enfrentando dilemas parecidos. No entanto, o que se percebe é que se as críticas são parecidas as respostas a elas são distintas.

Ao transformar o que foi originalmente um diálogo em um texto em primeira pessoa as marcas do diálogo permanecem, as perguntas, quando mudam o rumo da narrativa estão presentes na transcriação. Como no caso da entrevista de Aquiles em que minha intervenção aparece da seguinte forma: "Você me pergunta sobre minha vida antes de entrar no MST..." ou ainda "Em que momentos me sinto mais Sem Terra? Todos!”

A pergunta “quando se sente sem-terra?" embora não apareça textualmente em todas as entrevistas perpassou todos os encontros. Ela foi a pergunta de corte. ${ }^{126} \mathrm{Ou}$ seja, foi questão presente nas entrevistas para todos os participantes do projeto e se remete ao tema central dessa pesquisa. Ela foi formulada diretamente quando necessário, contudo em algumas situações foi respondida no conjunto da fala do entrevistado, não precisando aparecer de forma direta.

Essas transformações do texto oral para o escrito, foram definidas por Meihy ${ }^{127}$ como sendo um processo de transcriação.

Trata-se da transformação do que foi falado em escrita, "teatralizando o que foi dito, recriando-se a atmosfera da entrevista, procura-se trazer ao leitor o mundo de sensações provocadas pelo contato, e como é evidente, isso não ocorreria reproduzindo-se o que foi

\footnotetext{
${ }^{124}$ GEERTZ, Op. Cit., 2002, p. 183.

125 Idem, p. 8.

${ }^{126}$ MEIHY, Op. Cit. 2005.

${ }^{127}$ MEIHY, J. C. S. B. A colônia brasilianista: história oral de vida acadêmica. São Paulo: Nova Stella, 1990, pp. 15-27. E Canto de morte Kaiowá: história oral de vida. São Paulo: Edições Loyola, 1991, pp. 29-33.
} 
dito, palavra por palavra". ${ }^{128}$ Meihy denomina esse procedimento de postura "livre", em que é mais importante o compromisso com as idéias e não apenas com as palavras. ${ }^{129}$

O processo da transcriação, enfim, implica evidenciar o narrador em sua essência maior. O que interessa é jogar luzes na narrativa e não nas intermediações que devem, como os andaimes, cair desde que procedido o trabalho. ${ }^{130}$

Caldas levou o conceito a frente propondo-o não como uma etapa do trabalho, mas como todo o conjunto de interações entre entrevistador e entrevistado, que resulta na produção de um texto escrito final. ${ }^{131} \mathrm{E}$ chegou a afirmar que por todo o processo de feitura do texto final, o colaborador não pode mais ser tratado como objeto de conhecimento, passa a ser sujeito participativo.

O texto final (depois de ter passado por várias entrevistas, várias transcrições, vários encontros de leitura e por todo o processo de formação textual) jamais poderia ter sido pronunciado daquela maneira final pelo interlocutor; no entanto cada palavra, cada frase, cada estrutura the pertence (ele não disse, mas somente ele poderia ter dito). ${ }^{132}$

A transcriação é mais que uma edição do texto da entrevista. Leva em conta coisas que foram ditas e não foram gravadas, por isso é o resultado da interação. Mostra-se aqui dois exemplos simples, lembrando que análises detalhadas foram feitas por Santos e também por Brito. ${ }^{133}$

Elizandra aceitou dar sua entrevista, estávamos à sombra de uma árvore e ela tinha sua filha nos braços. Antes de começar a entrevista ela me apresentou Inara. Assim que liguei o gravador, Inara começou a chorar, entretanto só depois de falar por uns minutos, Elizandra, que a embalava desde o início, falou "Ô minha filha". $\mathrm{Na}$ transcrição o início da entrevista aparecia assim:

\footnotetext{
${ }^{128}$ MEIHY, Op Cit., 1991, p. 30/31.

${ }^{129}$ MEIHY, Op Cit., 1990, p. 28.

${ }^{130}$ MEIHY, Op Cit., 1991, p. 33.

${ }^{131}$ CALDAS, A. L. Transcriação em história oral. In: Neho-história. Nº 1, novembro de 1999. pp. 71-79.

${ }^{132}$ CALDAS, A. L. Nas águas do texto: palavra, experiência e leitura em história oral. Porto Velho:

Edufro, 2001, p. 36.

${ }^{133}$ SANTOS, A. P. À esquerda das Forças Armadas Brasileiras: histórias de vida de militares de esquerda. São Paulo: DH-FFLCH-USP, 1998. BRITO, F. B. de. Ecos da Febem: história oral de vida de funcionários da Fundação Estadual de Bem-Estar do Menor de São Paulo. São Paulo: DH-FFLCH-USP, 2002.
} 
Sou Elizandra, do Mato Grosso do Sul. Faço parte da Direção Estadual pelo setor de educação. Eu nasci em Dourados, no estado do Mato Grosso do Sul, mas a minha infância, a minha adolescência, um pouco da minha juventude mais grandinha foi numa cidade do interior próxima a Dourados, Douradina, município de Douradina. A minha infância foi maravilhosa, no sentido da vida no interior é boa de se viver. (choro de bebê) Ô minha filha.

Essa última frase, que poderia ficar sem sentido, transformou-se em "Essa aqui no meu colo é minha filha, Inara... Ô filha! Não chora não...”

Outro exemplo pode ser tirado da entrevista de Aquiles, que por estar muito gripado tossia o tempo todo. Por vezes ele não conseguia terminar suas frases e em meio à entrevista peguei um remédio para garganta que tinha comigo e dei para ele. As inúmeras interrupções provocadas pela tosse apareceram no texto final em frases como: "Não consigo nem falar direito de tanta tosse...", "Essa tosse não pára!" e "Minha voz está falhando... acho que por causa da tosse..."

Nessa medida, a própria criação dos documentos apresentados é em si um ato de interpretação, resultante de um encontro com os entrevistados. As narrativas são resultados de uma conversação, uma criação conjunta, desde o momento de sua gravação. A narrativa é organizada por sua estrutura vocabular, a partir das palavras usadas; por sua situação social, a interação intersubjetiva estabelecida entre os presentes; e por sua performance, pois quem fala, fala para uma audiência e essa performance é parte integrante da narrativa.

Desse encontro, o que é registrado é algo entre a história que o entrevistador quer construir e a história que o entrevistado quer contar. O que se tem acesso é uma seleção que de certa forma é uma auto-análise, resultante de um campo de tensão (a situação da entrevista).

Para a história oral o referente não é o acontecido, pois ele não pode ser capturado a não ser no momento imediato. A história oral é, portanto, o processo que converte "memória em história", aprisionando, 
concretizando, formalizando um momento que era volátil, passageiro e disforme, por meio da elaboração de um texto. Assim, pode-se pensar que no momento de uma entrevista o indivíduo fala sobre o acontecido, criando um novo referente. Num segundo momento, quando se transpõe o que foi dito para o papel, o que é chamado - genericamente de transcrição, passa a ser um novo referente. Isto, dada a impossibilidade de representação do passado tal como o ocorrido.

No fazer do historiador oral, ou como Meihy prefere chamar, do oralista, prevê-se a elaboração de um documento escrito que possa ser objeto de interpretação. Dessa forma a história de uma pessoa é tomada como texto para que possa ser analisada, assim como o faz Geertz com a cultura, e, portanto, o documento produzido pode ser submetido a uma teoria interpretativa.

Geertz, em sua obra, ${ }^{134}$ defende que a antropologia é hermenêutica, pois a interpretação se dá em todos os momentos do estudo, da leitura de um texto cheio de significados que é a sociedade à escritura do texto do antropólogo, e que por fim é interpretado por aqueles que não passaram pelas experiências do trabalho de campo nem da elaboração do texto escrito. Esse é um percurso comum às duas práticas, esse é um dos motivos de se pensar em uma hermenêutica para a história oral.

Mais um ponto em comum das duas teorias: ambas em seu trabalho se deparam com uma realidade complexa, multifacetada, para a qual quanto mais se olha, menor é a possibilidade de apreendê-la em sua totalidade. Por isso "demandam por uma interpretação; devem ser interpretadas"135. Assim, para a história oral também é coerente a afirmação de Geertz:

As assimetrias morais através das quais trabalha a etnografia, bem como a complexidade discursiva em que ela funciona, tornam indefensável qualquer tentativa de retratá-la como

\footnotetext{
${ }^{134}$ Destacam-se os livros de GEERTZ: Nova luz sobre a antropologia. Rio de Janeiro (RJ): Jorge Zahar; 2001; A interpretação das culturas. Rio de Janeiro (RJ): Livros Técnicos e Científicos; 1989; O saber local: novos ensaios em antropologia interpretativa. Rio de Janeiro (RJ): Vozes; 1997.

135 AZZAN Júnior, C. Antropologia e interpretação: explicação e compreensão nas antropologias de Lévi-Strauss e Geertz. Campinas: Ed. Unicamp, 1993, p. 95.
} 
mais do que a representação de um tipo de vida nas categorias de outro. ${ }^{136}$

Essa prática sem dúvida põe fim a muitas pretensões das ciências sociais de "contornar o incontornável de que todas as descrições etnográficas são de fabricação caseira, são as descrições de quem descreve, e não daquele ou aquilo que é descrito". ${ }^{137}$

Frente a essa complexidade não podemos mais pensar que esse pesquisador pode ser um reprodutor ou relator do dizer do outro. O pesquisador social deve ser autor e assumir sua autoria. Seu novo exercício é a construção da interpretação. Essa é a responsabilidade social de um pesquisador social. A idéia defendida nesse texto é de que o autor - oralista ou etnógrafo - deve ser um hermeneuta, e em seu texto fundar sua discursividade e construir sua obra.

A autoria de um texto tanto para a etnografia quanto para a história oral:

... em geral, não tem sido apresentada como um problema de ordem narrativa, uma questão da melhor maneira de se fazer com que uma história honesta seja contada honestamente, mas como um problema epistemológico, uma questão de como impedir que visões subjetivas distorçam fatos objetivos. ${ }^{138}$

Sobre isso Silva lembra que :

Mesmo que os antropólogos estejam conscientes de que os fatos não falam por si mesmos, conforme defendeu Malinowski, as etnografias pretendem que os documentos apresentados, as descrições, possam ser referidos como "fatos brutos", não contaminados pelo uso interpretativo que se quer fazer deles. Como se sua própria descrição, ou os elementos com os quase a compomos, já não fosse em si mesma uma forma de interpretação da realidade. ${ }^{139}$

É justamente frente a tal discussão que o conceito de transcriação ganha importância, pois subverte na própria criação do documento a possibilidade de "pureza". A narrativa resultante deste processo importa não por ser mais completa ou mais fiel. E sim, por

\footnotetext{
${ }^{136}$ GEERTZ, Op. Cit. 2002, p. 188.

${ }^{137}$ Idem, ibdem.

${ }^{138}$ Idem, p. 21.

${ }^{139}$ SILVA, Op. Cit, p. 121/122.
} 
incorporar a idéia de parcialidade, não apenas a do entrevistado, mas também a do entrevistador.

É possivel, entretanto, separar a descrição dos fatos de sua interpretação tanto na construção de um texto etnográfico como em sua leitura? Toda descrição já não é em si mesma uma interpretação circunstanciada pelas condições de sua observação? ${ }^{140}$

Destaca-se que no processo de produção documental o sujeito está presente e é sua presença que motiva a produção do documento. Sendo assim é muito dificil delimitar a fronteira entre descrição e interpretação. Ambas estão a todo momento presentes. De maneira apenas didática, pode-se marcar a existência mais intensa de uma e de outra, em certos momentos. O texto da entrevista é o lugar em que se pretende que o narrador apareça mais que o pesquisador. No restante dos textos dessa tese, pressupõe-se o contrário. A iniciativa de deixar a narrativa em primeira pessoa é tentativa de marcá-la como pessoal e subjetiva, em contraponto a um discurso homogeinizante e generalizador que impede a leitura de um texto como resultado de uma experiência.

Da mesma forma, não se pensa que as tramas biográficas registradas dêem conta do que é cada entrevistado. O texto que ora se apresenta também não é a totalidade da pesquisa desenvolvida. Muito se perdeu. Aqui como lá, tem-se acesso às versões, apanhados de momentos, vistos à luz dos olhos de hoje, sobre o acontecido ou sobre o que se lembra ter ocorrido.

É comum ouvir, quando se fala do trabalho com memória, que ela é fluída. E é realmente. Mas se isso vale para os narradores, deve valer também para os pesquisadores.

O que deve importar, portanto, é entender como a pessoa se descreve, ou, quais suas verdades e pontos de vista sobre as coisas. No entanto, dizer isso não basta, Mary Marshall Clark, ${ }^{141}$ a partir de sua

\footnotetext{
${ }^{140}$ Idem, p. 124.

${ }^{141}$ Diretora do Oral History Research Office da Universidade de Columbia, Nova Iorque, Estados Unidos da América.
} 
experiência com um projeto sobre o 11 de setembro em Nova Iorque, lembra que muitas vezes as pessoas reproduzem verdades ouvidas, como se fossem suas. No caso específico de eventos como o atentado terrorista que atingiu as torres do World Trade Center, algumas pessoas acabavam por não ter suas próprias opiniões sobre sua própria experiência. Segundo Clark isso se deu pois a mídia inundou a todos com informações, o que fez com que, muitas vezes o que primeiro surgisse nas entrevistas fosse essa percepção mais generalizada, e somente com algum tempo e conversa aquelas percepções padrão puderam ceder lugar para pensamentos e impressões mais particularizados. ${ }^{142}$

Conforme trabalhava com os membros do Movimento Sem Terra, percebi que alguns assuntos eram mais relevantes que outros, e isso ajudou bastante a constituir as diversas entrevistas em tão pouco tempo. Primeiramente, pela facilidade do contato e entrada na comunidade, mas também por dominar um conjunto de referências que faziam com que a comunicação fosse facilitada e se tornasse mais efetiva.

Sem esquecer dos ensinamentos de Clark, é preciso pensar no MST como um instrumento da criação dessas percepções. Não como vêm fazendo tantos críticos do Movimento, que de modo leviano apontam sua ação como simplesmente dogmatizadora. Há muitas nuances nessa cena. Mas a que gostaria de discutir aqui é que a maioria dessas pessoas não tinha inserção no mundo para além de seus cotidianos. Uma das entrevistadas - cuja narrativa não se encontra na integra, neste trabalho - contou que antes de fazer parte do Movimento, não sabia nem qual era sua cor predileta. Nunca tinha pensado sobre isso. Dessa forma, essas pessoas encontram no Movimento um fator de empoderamento, agora não estão mais sozinhos e podem falar por todo um grupo. Têm uma história. Evidentemente,

${ }^{142}$ CLARK, M. M. Memory, Identity and Trauma: Reflections on Gender in the September 11, 2001. Oral History Narrative and Memory Project, palestra proferida no dia 5 de junho, durante o Summer Institute on Oral History - Women's Narratives, Women's Lives: Intersections of Gender and Memory, realizado na Universidade de Columbia, Nova Iorque de 5 a 16 junho de 2006. 
como afirmou Portelli, uma cultura é formada por uma diversidade de indivíduos e esses indivíduos, por diferentes pensamentos e idéias. Isso pode ser transposto para a comunidade dos sem-terra, de forma que há uma grande variedade de percepções e pensamentos dentro do Movimento, que conformam identidades diversas, entretanto é preciso destacar que a mais facilmente acessivel é a identidade organizada pelas lideranças do Movimento.

Paralelamente, ao construir as histórias de vida faz-se com que cada narrador se transforme em personalidade central dos acontecimentos daquela comunidade e tenha a oportunidade de mostrar suas próprias percepções. Com essa perspectiva, não se pretende forjar "novos heróis", mas apenas comprovar que qualquer colaborador é tão importante como agente histórico quanto os líderes ou os governantes reconhecidos pela "história oficial", pois:

Todas las narraciones personales tienen una función politica, ya que originan una determinada manera de ver el mundo que privilegia unos determinados intereses (historias y significados) sobre otros, tengan o no contenido político explícito. Para desentrañar la ideología en la narración personal se requiere un análisis de la estructura y significados profundos, dentro un discurso de textos y participantes múltiples... Contar narraciones personales puede legitimar significados dominantes o resistir significados dominantes en una transformación de significados. ${ }^{143}$

É importante dizer que se intenciona fugir do que a maior parte dos trabalhos que se baseiam na história oral tem feito, nas palavras de Ronald Grele: "oscilar entre os extremos de um populismo entusiasta, onde o historiador desaparece para dar voz ao 'povo' e uma concepção tradicional de historiografia 'objetiva' na qual o historiador/autor assume uma posição privilegiada como intérprete das interpretações de seus entrevistados". ${ }^{144}$

Assim, a pesquisa qualitativa valoriza o subjetivo, e a identidade de um grupo como reflexo das experiências e sentimentos

\footnotetext{
${ }^{143}$ LANGELLIER, K. citado por GRELE, R. J. La Historia y sus Lenguajes en la Entrevista de Historia Oral: Quién Contesta a las Preguntas de Quién y Por Que? In: Historia y Fuente Oral, n 5, 1991, p. 112.

${ }^{144}$ GRELE, Op. Cit., p. 111-12.
} 
dos indivíduos que o compõem. Thompson ${ }^{145}$ disse que alguns grupos sociais, colocados à margem do poder, não possuem fontes documentais, isso ocorre principalmente com subculturas desviantes, estudadas por sociólogos através da história oral de vida durante muito tempo. Além disso, Thompson aponta uma aproximação positiva entre o saber acadêmico e o saber popular, pois:

... a natureza da entrevista implica uma ruptura da fronteira entre a instituição educacional e o mundo, e entre o profissional e o público comum. Pois o historiador vem para a entrevista para aprender: sentar-se ao pé de outros que, por provirem de uma classe social diferente, ou por serem menos instruidos, ou mais velhos, sabem mais a respeito de alguma coisa. ${ }^{146}$

Esse aprendizado se deu por meio de uma conversa, em que se escutou muito e se perguntou pouco. Mas como vimos no decorrer desse texto, narrar nossas memórias (vividas e escutadas) é um ato social de interação.

Entendemos o ser humano como um ser dialógico, relacional, que se vai construindo a partir das relações que vai estabelecendo com os outros seres humanos, sem perder sua singularidade, pois continua sempre sendo um ser único e irrepetivel, sua subjetividade é composta das milhões de relações que ele estabelece durante toda sua existência. ${ }^{147}$

Posto isso, há que se fazer referência a um outro ponto de convergência entre as teorias antropológicas modernas e a história oral, o enfrentamento da objetividade - que deve ser tomado em conjunto com uma discussão sobre ciência, que sem dúvida merece maior detalhamento e atenção, o que não será possivel neste trabalho. Para ambas a objetividade é algo inalcançável, mas suas respostas a isso também são diferentes.

O que Geertz propõe "para uma etnografia do pensamento é um estudo sobre a intersubjetividade". ${ }^{148}$ Algo como uma subjetividade

\footnotetext{
${ }^{145}$ THOMPSON, P. A voz do passado. São Paulo: Paz e Terra, 1998.

${ }^{146}$ Idem, p. 32/33.

${ }^{147}$ STREY, M. N. (et al.). Psicologia social contemporânea: livro-texto. Petrópolis-RJ: Vozes, 1998, p.56.

${ }^{148}$ AZZAN, Op. Cit, p. 90.
} 
do campo baseada em uma objetividade acadêmica. Geertz aponta os riscos do subjetivismo e como evitá-los ao dizer que: "A única defesa contra isso e contra tornar a análise cultural um tipo de esteticismo sociológico é treinar as análises para tais realidades e necessidades em primeiro lugar". 149

O estudioso de uma sociedade atual, que faz trabalho de campo, é obrigado a deparar-se com uma frágil objetividade, passa a ter que olhar de frente a subjetividade, e um pequeno distanciamento temporal de seu objeto de pesquisa - o que para a história já foi um grande problema. Ao acreditar na existência de reciprocidade entre objeto e sujeito, não se pode negar a trabalhar com o papel de sua subjetividade sobre o conhecimento que produz. "Em outras palavras, não se pode mencionar um objeto sem mencionar ao mesmo tempo quem o apreende e como ele o apreende."150

Por sua vez a história oral também acredita em uma intersubjetividade, mas que parece muito mais relacionada aos sujeitos envolvidos - pesquisador e "pesquisado" em contraponto com o par pesquisa de campo e academia - destacando a importância da experiência de vida do indivíduo. O “pesquisado" não é mais informante, ator ou objeto de pesquisa, ele é sujeito.

$\mathrm{O}$ encontro entre os entrevistados/sujeitos e o pesquisador/sujeito estabelece a relação de intersubjetividade, que marca uma conduta diferenciada, reafirmando a existência de um compromisso entre sujeitos. Defendo aqui que essa relação não seja de oposição ou enfrentamento, mas sim de atenção e colaboração.

O processo de colaboração tem a conferência como parte fundamental da experiência de pesquisa. Esse é o momento final do trabalho com as narrativas. Em todos os trabalhos realizados, essa sempre foi considerada mais que uma etapa de criação do documento, uma necessidade ética, de demonstração de respeito ao entrevistado.

\footnotetext{
${ }^{149}$ GEERTZ, C. The Interpretation of Cultures, p. 30, citado por AZZAN J., C. Op. Cit. p. 93.

${ }^{150}$ BÉDARIDA, F. Tempo presente e a presença da história. In: FERREIRA e AMADO, (orgs.) Op. Cit., 1996, p. 219.
} 
Entretanto, neste trabalho, não consegui que ela fosse realizada a contento.

No momento das entrevistas, sabendo das dificuldades de encontrar-me pessoalmente com aqueles entrevistados novamente, busquei anotar endereços, telefones e correios eletrônicos para contatos futuros. Primeiramente é necessário que se diga que nem todos tinham essas informações, muitas vezes tive acesso aos contatos de um celular do acampamento. Com o passar do tempo, e as constantes mudanças desses sem-terra, essas informações coletadas se mostraram inúteis.

Naquele primeiro momento, pensei mesmo ser possível localizar as pessoas e realizar todas as conferências das entrevistas feitas na marcha de 2005, a tempo de minha defesa.

Colocar as narrativas aqui, da forma que se apresentam, foi uma decisão bastante difícil, pois realmente acho que esses homens e mulheres que generosamente contaram suas histórias, deveriam ter sido contatados, um a um, por um comprometimento que assumi com eles na entrevista, quando disse que nos falariamos ainda para que cada um validasse todo aquele conjunto de "coisas" que tinham sido ditas. Dessa forma, o trabalho de localização e conferência desses textos ainda está em processo, com a ajuda da Secretaria Nacional do MST.151

Essas colocações sem dúvida desembocam em uma preocupação ética. A devolução deste trabalho é algo que ainda precisa ser finalizado. Com isso quero dizer que o que se apresenta é um trabalho incompleto, posto que as conferências não aconteceram. Não porque ache desnecessário.

Mesmo com uma longa vivência e conhecendo bastante o Movimento e sua dinâmica seria arrogância, falar que isso não implicou em nenhum custo para o que sempre pensei como básico para uma pesquisa. Acho que essa vivência estabeleceu uma relação de colaboração com a organização MST. No momento da marcha e da gravação das entrevistas ela aconteceu com as pessoas envolvidas na

\footnotetext{
${ }^{151}$ Em especial devo meus agradecimentos à Andréa Francine Batista, que tem se dedicado a essa tarefa pessoalmente.
} 
pesquisa, mas há ainda muito trabalho a ser feito. Essa é uma característica da colaboração, ela não se esgota na escritura de um texto, é processo contínuo. Principalmente, sabendo que uma das discussões que permeiam o fazer da história oral diz respeito à ética das relações estabelecidas com os entrevistados.

Dizer que ética é relação, ou dizer que ética só se pode aplicar às "relações", é afirmar que ninguém pode se arvorar o predicativo de "ético" a partir de si mesmo, (...). O pensamento liberal, ao partir da definição de ser humano como "indivíduo", centraliza tudo no "eu", no sujeito da proposição. Perdemos a dimensão relacional, e como conseqüência mistificamos o verdadeiro sentido de ética. (...) Por incrivel que pareça quem vai decidir se somos, ou não, éticos, são os outros. (...) A dimensão ética se apóia diretamente sobre essa antropologia personalista e dialógica. Reconhecemos o "outro" como pessoa com quem entramos em diálogo, e não como um simples "indivíduo" que está ao nosso lado, com quem entramos em contato pelo simples motivo de sobrevivência, em competição potencial conosco. Na afirmação do Dussel (1977, p.98), no reconhecimento dessa alteridade "consiste toda a eticidade da existência”. ${ }^{152}$

Não foi apenas no final que os procedimentos éticos da pesquisa foram colocados em cheque. Foi necessário enfrentar essa questão ao ouvir Seu Luis repetidas vezes se referir à entrevistadora como "senhora", enquanto transcrevia a entrevista de:

Tenho feito muitas entrevistas, essa é mais uma entrevista e mais aproveitada para mim. Estou gostando dessa entrevista. Eu gosto de dar entrevista. Não vou fora de dar entrevista, que quem falar, eu falo, se quiser falar mais com ele, eu falo, se não quiser eu não falo também. Eu acho muito importante. Eu me sinto muito importante. Não mais que a senhora. Pessoa estudada. Eu sou um analfabeto por dentro, para começar. Converso do jeito que aprendi a conversar, do jeito caipira.

A tal escuta ativa e "não violenta" que tinha para mim como fundamental poderia não ter acontecido. As relações de poder estavam ali. Demorei para acreditar no que ouvia. Não consegui fazer com que um homem, muito mais velho que eu, deixasse de me ver como

${ }^{152}$ STREY, Op. Cit., p. 56. 
"senhora" ou "pessoa estudada". Por questão de respeito, formalidade, a relação que pretendia entre iguais foi colocada às claras por Seu Luis. Não éramos iguais, e provavelmente minha escuta foi tão violenta ou tão prazerosa quanto qualquer outra entrevista que ele já tivesse dado.

Ao debater essa questão com outros pesquisadores, surgiu a hipótese de que essa poderia ter sido uma maneira "marota" de Seu Luis valorizar seu próprio ato de narrar. Valorizar o interlocutor, ao ver que ele aprendia com suas palavras, seria também uma forma de dizer o oposto do que foi dito. Essa também é uma interpretação viável. Apresento ambas como demonstração da multiplicidade de leituras que uma narrativa pode guardar.

\section{Diversidade epistemológica: diálogos com história oral}

Este capítulo foi escrito de forma a evidenciar alguns diálogos entre várias áreas de produção de conhecimento e a história oral, primeiramente no que se refere às definições dos conceitos de memória e de narrativa, seus usos e desdobramentos para a prática da história oral.

Sobre a prática de pesquisa, outro diálogo se apresenta, frente a demanda do trabalho de campo e o uso das histórias de vida.

Foi das leituras de Geertz que surgiram muitas das reflexões presentes nesse trabalho, suas colocações são muito provocadoras e ao ler uma passagem do prefácio de seu livro "Nova luz sobre a antropologia" percebi que muito poderia ser relacionado, não apenas por serem a história oral e etnografia partes das chamadas ciências

humanas, mas por sofrerem cobranças muito parecidas. Repito a passagem aqui, por esclarecer boa parte do que quero com as reflexões registradas nesse texto:

Como convém a duas disciplinas não claramente definidas e voltadas ambas para tudo o que diz respeito à vida e ao pensamento humano, a antropologia e a filosofia são mais do que suspeitas uma para a outra. A ansiedade decorrente de relacionar tudo a praticamente tudo, para assim chegar ao 
fundo das coisas, deixa-as inseguras quanto ao que cada uma deve fazer. Não que suas fronteiras as confundam; antes, não têm fronteiras claramente demarcáveis. Não que seus interesses divirjam; ao contrário, parece que a elas nada escapa. ${ }^{153}$

Evidentemente, Geertz busca estabelecer um diálogo com a filosofia, mas não penso serem diferentes os conflitos quando se propõe olhar a história oral.

A antropologia assim como a história está vivenciando um momento de mudança de seus modelos. Hoje, os antropólogos não se deparam apenas com sociedades ditas "simples", o mundo é agora muito mais integrado e desenvolvido, logo tudo é conectado a tudo, mas de forma bastante complicada. ${ }^{154}$ Há muito mais pessoas trabalhando nas áreas em que antes antropólogos costumavam trabalhar sozinhos. Isso faz com que a antropologia seja mais do que a soma das coisas, o que a torna dificil de operar. Nas palavras de Geertz a antropologia não pode mais ser uma ciência completamente geral, que estuda tudo, que diz estudar o "Homem". Ela tem que perceber qual é o seu papel particular em cada sociedade e interpretar o que ocorre. Isso ao lado de outras disciplinas, como economia, politica, história, literatura.

É desse novo mundo, que emerge a proposta de uma mudança de teoria. Para explicar o presente contexto, Geertz formula a seguinte metáfora: "fitar paisagens de naturezas mortas é uma coisa; observar panoramas de colagens é outra muito diferente". ${ }^{155}$ A diversidade cultural tomou conta de nossas telas, as fronteiras que as distinguiam não são mais nítidas.

Em termos mais concretos, as questões morais provenientes da diversidade cultural [...] as quais se é que chegavam a surgir, surgiam, sobretudo entre sociedades, surgem agora, cada vez mais, dentro dela. ${ }^{156}$

A mudança do mundo impôs uma revisão das práticas de cientistas socais e isso foi percebido também na disciplina da história. $\mathrm{E}$

\footnotetext{
${ }^{153}$ GEERTZ, Op. Cit, 2001, p. 7.

${ }^{154}$ Idéias presentes no capítulo “Os usos da diversidade” In: GEERTZ, C. Op. Cit. 2001, pp. 68-85.

${ }^{155}$ Idem, p.83.

${ }^{156}$ Idem, p.77.
} 
como Geertz disse a respeito da antropologia, também se pode dizer sobre a história, ao emergir "algo novo 'no campo' e 'no mundo acadêmico' há que aparecer algo novo na página". ${ }^{157} \mathrm{E}$ isso foi o exercício desenvolvido nessa tese.

Para tanto, esse capítulo trabalhou os conceitos de memória e de narrativa de forma complementar, destacando os usos e práticas desses conceitos contemporaneamente em várias áreas de conhecimento. Por fim, a intenção foi desdobrar tais contribuições para o campo da história oral, como uma forma de pensar sobre a própria prática da pesquisa desenvolvida.

${ }^{157}$ GEERTZ, Clifford. Op. Cit., 2002, p. 193. 


\section{Exclusão: uma história anterior ao MST}

...quando eu era criança minha mãe e meu padrasto trabalhavam para fazendeiro. Trabalharam a vida toda. Eu tinha sete anos quando fui para companhia do meu padrasto. A minha mãe é mãe solteira, não tive chance de conhecer meu pai... Minha mãe trabalhava em sítio dos outros. A mão da minha mãe era calo puro, parecia a mão de homem... Aquela mão toda estourada. Meu padrasto também. Eles trabalhavam dia e noite, direto, não tinha salário decente... Não tinha nada. Wanderléia

Como viviam os narradores antes da entrada no MST? Por que se sentem atraídos pelo Movimento? O quê procuram? Qual(is) sonho(s) querem realizar? Do que fogem? Essas foram as questões que geraram esse capítulo e que tentarei responder ao longo dele, recorrendo aos trechos das entrevistas em que esse tema se evidenciou.

A primeira colocação, e mais importante, é que ao entrar no MST essas pessoas buscam a saída da exclusão. Querem vencê-la. Querem modificar suas vidas e abandonar a vivência traumática que tinham antes. Como no caso de Wanderléia:

... antes eu não tinha nada, antes eu não era, não me sentia nada na vida... Antes, trabalhava de doméstica... Um dia ia trabalhar, outro dia não tinha emprego mais... Chegava na casa das pessoas para trabalhar e era tratada igual cachorro! Só comia se sobrasse comida. Quando voltava para casa ainda tinha que fazer o serviço de casa, tinha que fazer comida, lavar a roupa tarde da noite para deixar no outro dia para as crianças. Não tinha tempo de cuidar dos meus filhos, nem da minha casa... do meu barraquinho. Porque pobre não tem casa, não dá, não tem como. Era um barraquinho pequenininho em Japeri. Não era uma vida digna! Mesmo trabalhando, quando levantava de manhã não tinha o que dar para as crianças comer, não sobrava dinheiro, porque tinha que pagar água, luz...

A falta de perspectiva e de possibilidades de melhoria, a exclusão social, o não envolvimento, o sentir-se fora do lugar são razões 
que fazem com que essas pessoas queiram fazer parte do Movimento. Assim, a entrada no MST, muitas vezes se dá como resultado de uma falta de opções, acontece como conseqüência da invisibilidade da vida anterior. A opção se configura posteriormente ao momento do ingresso, na permanência ou não. Esse momento, posterior, de escolha, será tratado nos capítulos à frente, pois é aí que se pode ver quem realmente se identificou com o Movimento. Importante marcar que a permanência foi opção feita pelos narradores dessa pesquisa, posto que não se buscou entrevistar nenhuma pessoa que tenha feito a opção contrária, embora esse assunto tenha grande relevância e tenha se tornado uma preocupação nos últimos anos de pesquisa.

É uma constante a entrada e saída das pessoas no Movimento, e dentre outros motivos esse é fundamental para pensar as alternativas de pertencimentos e as identidades sem-terra, como algo em contínua construção e por isso mesmo fluído, móvel, mutante.

Tornamo-nos conscientes de que o "pertencimento" e a "identidade" não têm a solidez de uma rocha, não são garantidos para toda a vida, são bastante negociáveis e revogáveis, e de que as decisões que o próprio individuo toma, os caminhos que percorre, a maneira como age - e a determinação de se manter firme a tudo isso - são fatores cruciais tanto para o "pertencimento" quanto para a identidade. Em outras palavras, a idéia de "ter uma identidade" não vai ocorrer às pessoas enquanto o "pertencimento" continuar sendo o seu destino, uma condição sem alternativa. ${ }^{158}$

Nesse sentido, pensando na possibilidade de escolha, pode-se dizer que no Movimento homens e mulheres trilham um caminho para a conquista da cidadania, para o alargamento de um espaço público, ${ }^{159}$ ou para enfraquecimento do que Agamben chamou o "poder soberano" e o abandono de um a "vida nua", 160 sendo que essas "duas esferas não podem ser separadas e que a implicação da vida nua na esfera política

\footnotetext{
${ }^{158}$ BAUMAN, Z. Identidade. Rio de Janeiro: Jorge Zahar editor, 2005, p.17-18.

${ }^{159}$ CHAUI, M. Público, privado, despotismo. In: Novaes, A. (org.) Ética. São Paulo: Companhia das Letras, 1996, p.345 - 390.

${ }^{160}$ Vida nua é um conceito utilizado por Agamben que faz referência a uma vida desprovida de política e de bem viver. É a vida “zoe” e não “bios”, é a vida animal. AGAMBEM, G. Homo sacer: o poder soberano e a vida nua I. Belo Horizonte: Ed. UFMG, 2002, p.10.
} 
constitui o núcleo originário - ainda que encoberto - do poder soberano."161

Uma "vida nua" foi representada nas entrevistas de diversas maneiras. Um caso extremo foi contado por Wanderléia:

Eu sentia arrasada porque a gente não conseguia ir para frente, não conseguia, não é melhorar de vida, ficar rico... Mas ter uma vida mais decente... Eu não conseguia, não conseguia... Minha mente ficou tão ruim que eu pensei em acabar com tudo.

Essa vida desprovida de "bem viver" aparece relacionada aos lugares e às condições de habitação dessas pessoas, nos problemas de falta de escolarização e de saúde. Situações que fazem com que as pessoas se sintam humilhadas cotidianamente.

A questão da moradia tem que ser vista sob dois aspectos: um mais concreto e objetivo, como abrigo para a família, e outro subjetivo, como lugar do aconchego, o espaço da família. Ambos se refletem no orgulho em mostrá-la e o conforto de viver em um espaço melhor, como explicou Ana Paula:

O dinheiro era muito pouco. Mas meu pai fez outra casa para gente. Nossa casa era bem feinha, bem pacata mesmo! Nossa casa ele fez de barro e cobriu de telha porque antes era de palha. Isso para nós foi ótimo! Foi um avanço muito grande financeiramente. Meu pai trabalhava na roça. Mas essa terra era do fazendeiro.

A ausência da ação do Estado e de políticas públicas voltadas para a população mais carente pode ser percebida no trecho em que Wanderléia falou:

Quando as crianças ficavam doentes, tinha que ir para fila do posto de saúde. Tinha que se humilhar para conseguir uma consulta, senão voltava com as crianças doente para casa. Sabe o que é uma mãe ver os filhos queimando em febre e não ter como ter socorro? Era tratada igual cachorro!

Outra marca de quase todas as entrevistas de história de vida, que compõem esse trabalho, é a origem humilde dessas pessoas.

${ }^{161}$ Idem, p.14. 
Esta origem ganhou explicações sucintas como a de Adelir: "Sou filho de família pobre". Ou ainda bem longas como a de Ana Paula, que conta toda a história de sua mãe antes mesmo dela nascer, fazendo referência ao conjunto de privações a que sua mãe foi submetida, expresso em frases como: "Ela comprou poucas coisas para mim, do enxoval". Ou ainda: "ela me teve com a maior dificuldade. Sozinha, só com minha avó. Às vezes, minha avó ficava lá fora (do hospital) também, passou muita fome porque ela não tinha dinheiro para comprar comida." Para finalmente concluir que: "Aí começou nós..."

Seu Luiz falou pouco dos tempos de criança, mas deu destaque à falta de estudo e da necessidade de trabalhar desde criança:

De menino, meu pai foi me ensinar a trabalhar... Não sabia assinar o nome. Meu pai me ensinou a conhecer as letras. Conheci as letras. Peguei estudando com um, com outro... Aprendi a assinar os nomes. Ai fui trabalhar para a roça, para o campo, só trabalhando. Quando é de noite a gente chega cansado, não tinha tempo de estudar. Não aprendi muita coisinha...

O trabalho na lavoura, aprendido na infância, o acompanhou pela vida. Bóia-fria, empregado ou trabalho de empreita, cana, café ou capim, seu Luiz fez de tudo um pouco, sempre migrando em busca de possibilidades de trabalho. Destino que seus filhos seguiram e que marcam a dura vida de trabalhador rural, migrante pelo Brasil.

Mesmo Elizandra, que narra sua infância positivamente, dizendo que pôde estudar e brincar, afirmou: "Vim de uma família humilde." Pode-se perceber em sua narrativa a questão do abandono do campo e da divisão das tarefas domésticas. Elizandra marcou em sua entrevista como o trabalho de toda a família era necessário para pagar as contas da família:

No final de semana era todo mundo, todos os meus irmãos juntos, a minha mãe, trabalhando no bar para pagar o aluguel da casa onde era a lanchonete. E também para comprar comida e as coisas para a gente. Sempre tinha quando precisava de alguma ou outra coisinha, porque a gente ajudava. Sempre trabalhamos em familia para 
conseguir adquirir pelo menos para o sustento família. Não faltava, mas também não sobrava. Batalhava para caramba. $\mathrm{E}$ acho que o importante era que um ajudava o outro.

Em tramas biográficas como a de Ronaldo, também se pode perceber a origem pobre, de trabalho para outrem no campo, vinculada a um cotidiano de proibições. Em sua história de vida falou que as melhores coisas que se lembrava da infância eram as viagens para a praia e as partidas de futebol na volta da escola. No entanto, mais tarde o fazendeiro resolveu não deixar mais que jogassem bola no campo da fazenda. A partir dessa colocação, um pouco depois, ele fez uma comparação com a vida no assentamento, que acompanha o pronome possessivo "nosso", refletindo sobre sua maior liberdade e sobre o orgulho de poder celebrar algo que é também constitutivo de sua identidade paraibana:

Era dificil outros dias assim [de lazer], como esse. Na fazenda não tinha festa de São João, porque o camarada não deixava. Agora, no assentamento nosso, todo ano tem Festa Junina com a quadrilha que é apresentada na cidade, em Mari, e nos outros sítios ao redor. Quando estou em casa e tenho tempo, eu danço. E gosto. Nossa, é uma tradição boa para nós!

Pode parecer menor considerar a ausência de festas ou de jogos no cotidiano das pessoas como formas de opressão, afinal não são atividades essenciais à vida humana, interpretada como zoe.162 Contudo, para a diferenciação entre uma "vida nua" e uma vida plena, essas pequenas ações do cotidiano ganham relevância. Esses fatos marcaram tanto a trajetória de Ronaldo que ele respondeu à pergunta sobre o que seria a pior lembrança de sua vida com palavras assim:

O momento mais dificil, que não quero viver mais nunca e, hoje, eu tenho fé em Deus que não vou viver mais, é viver em fazenda. Viver obrigado a um camarada que manda em tudo.

\footnotetext{
162 “Os gregos não possuíam um termo único para exprimir o que nós queremos dizer com a palavra vida. Serviam-se de dois termos, semântica e morfologicamente distintos, ainda que reportáveis a um étimo comum: zoe, que exprimia o simples fato de viver comum a todos os seres vivos (animais, homens ou deuses) e bíos, que indicava a forma ou maneira de viver própria de um indivíduo ou de um grupo.” Agamben, G. Op. cit., p.9.
} 
A gente levava muito esporro do administrador da fazenda. Mesmo a gente que não trabalhava lá.

A figura do administrador da fazenda, como representante do fazendeiro, caracteriza uma situação de poder que também merece uma reflexão, na medida em que é figura representativa da opressão:

Esse administrador não sabia falar com as pessoas. Para ele, a gente era um monte de burro bravo, só ia na volta do grito, nos carão, nos esporros. Não media canto, nem hora, nem espaço para falar. Ficava muito indignado com isso.

Pode-se dizer que todos esses conflitos afetam negativamente as relações de trabalho e, consequentemente, a vida dos trabalhadores. Por outro lado, a exploração desses trabalhadores compromete a renda e como conseqüência, sua possibilidade material de bem viver. É disso que fala Wanderléia, ao justificar sua saída do campo:

Não deu certo no sítio, porque o que ganhava não dava nem para comer, o patrão dava uma miséria (...) Não tinha mais nada para comer, daí não agüentei, falei vamos embora para cidade, vou trabalhar de doméstica...

Seja pela falta de lazer, pelas condições de trabalho ou pela baixa renda, esse passado se caracteriza em todas as narrativas como opressor e violento. Mas é preciso salientar que a violência e injustiça a que os trabalhadores ou moradores do campo no Brasil são submetidos não pára aí. Aquiles evidenciou o extremo dessa violência quando contou:

Completou 21 anos de assentamento. Nesses anos, o processo da gente foi esse, junto com os pais nossos. Antes, a gente cuidava... com 11 anos a gente pegava em espingarda para enfrentar os pistoleiros do fazendeiro. A polícia federal também ia lá e abusava bastante de nossos pais, na questão de pegar o animal que a gente tinha. Mandava matar: jegue, cachorro, tudo. Mandava derrubar as casas nossas. Pistoleiro junto com a polícia. Os pistoleiros derrubando e a polícia dando suporte. A polícia federal e a militar. Aquilo era um desgosto!... A gente achava que ia crescer com aquele desgosto na cabeça, de ódio. 
A violência do campo brasileiro não envolve apenas os conflitos entre patrão e empregado. A disputa por terras é uma constante, e não acabou com o fim da Ditadura Militar, período em que na tentativa de controlar os problemas da terra o governo federal passou a orientar "a militarização da questão agrária"163, transformando problemas fundiários em questão de Segurança Nacional, e criando o Ministério Extraordinário para Assuntos Fundiários. "Pode-se constatar que com o final do governo militar - anos de 1985 e 86 - a violência se intensificou, gerando a terrivel estatística de morte 'um trabalhador rural a cada dois dias"”. ${ }^{164}$

Dessa forma, violência tem sido a principal característica da luta pela terra no Brasil. Os dados expressos no gráfico 1 sobre o número de mortos em conflitos no campo mostram que essa violência parece não ter fim. No período entre $1964 \mathrm{e}$ 1971, a maior parte das mortes ocorreu na região Nordeste, na intenção dos latifundiários de frear, pela violência, os ideais semeados pelas Ligas Camponesas. A partir de 1972 foi na Amazônia que se concentrou a maior número de assassinatos no campo, embora continuassem presentes também no Nordeste e no Centro-Sudeste. A década de 70 foi marcada sobretudo pela luta dos posseiros na Amazônia. O governo militar com sua política territorial voltada para os incentivos fiscais aos empresários, de um lado, e de outro fomentando, também na Amazônia, a colonização como alternativa à Reforma Agrária nas regiões de ocupação antiga (NE, SE e S), criou o cenário para a violência. ${ }^{165}$

\footnotetext{
${ }^{163}$ A esse respeito ver MARTINS, J. S. A militarização da questão agrária. Terra e poder: o problema da terra na crise política. Petrópolis/RJ: Vozes, 1985.

${ }^{164}$ RIBEIRO, S. L. S. Op. Cit, 2002, p. 52.

165 OLIVEIRA, A. U. A longa marcha do campesinato brasileiro: movimentos sociais, conflitos e reforma agrária. Estudos Avançados / Universidade de São Paulo. Instituto de Estudos Avançados, volume 15, número 43, São Paulo: IEA, setembro/dezembro 2001, p. 191.
} 

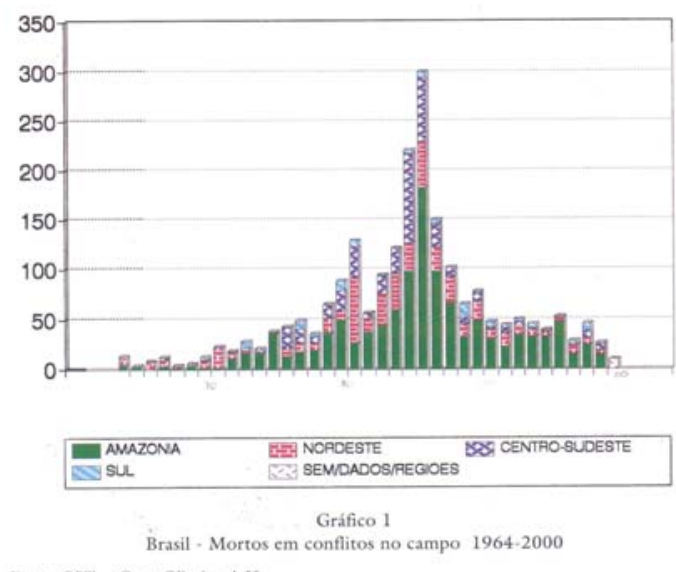

Fonte: CPT Org: Oliveira, A.U

Talvez por isso mesmo no ano de 1986 o Ministério da Reforma Agrária, sob o governo Sarney, lançou uma campanha publicitária em televisão, em que se dizia que o campo brasileiro, não deveria se tornar um "campo de batalha". A guerra que se travava no campo gerou muitas baixas. Números impressionantes moveram por anos a ação da Pastoral da Terra e dos Sindicatos de trabalhadores rurais. ${ }^{166}$

...entre $1 / 1 / 1964$ e 31/12/1989, apontam a ocorrência de 1.566 assassinatos de trabalhadores rurais, indios, advogados, religiosos e outros profissionais ligados à luta pela terra. Foram realizados dezessete julgamentos em vinte e seis anos e condenados os envolvidos em dois casos de homicídio de índios, três sacerdotes e três advogados. Nesse período nenhuma condenação ocorreu por assassinato de trabalhador rural. 167

A Comissão Pastoral da Terra - CPT - foi responsável por, em um primeiro momento, organizar e articular movimentos populares camponeses. A orientação metodológica da CPT pautou-se no sentido de que os próprios camponeses assumissem a luta como sujeitos do processo. Isto constituiu-se num elemento fundamental. Em seu trabalho junto às paróquias nas periferias das cidades e às

\footnotetext{
${ }^{166}$ A ação da CPT, criada em 1975, merece destaque, pois em seus relatórios denunciava a dimensão da violência ocorrida no campo em todo o país.

${ }^{167}$ IOKOI, Z. M. G. Igreja e camponeses: teologia da libertação e movimentos sociais no campo, Brasil e Peru, 1964-1986. São Paulo: Hucitec/Fapesp, 1996, p. 112.
} 
comunidades rurais, a CPT exerceu e fez outros exercerem importante papel de resistência no regime militar.

Os conflitos, apesar da repressão e da censura, multiplicaram-se rapidamente em todas as regiões do país, envolvendo não só os trabalhadores rurais, mas também os povos indigenas, cujas terras passaram a ser invadidas, com a conivência oficial, em escala nunca vista. Nesse quadro de crescimento do número de conflitos, a Igreja, e particularmente a Igreja das regiões pioneiras, do CentroOeste e da Amazônia, foi profundamente envolvida na defesa dos trabalhadores rurais, submetidos a violências inomináveis, que iam e ainda vão desde a escravidão por dívida até o assassinato puro simples. ${ }^{168}$

Porde-se dizer, segundo Leonardo Boff:

O inconformismo popular foi sempre reprimido com extrema violência, a ponto de o historiador mulato Capistrano de Abreu ter dito rudemente que "o povo foi capado e recapado, sangrado e ressangrado". ${ }^{169}$

Importante marcar a posição de alguns acadêmicos que se impressionaram e desenvolveram pesquisas sobre tal situação apontando a situação injusta e violenta que envolvia e envolve a ocupação e distribuição das terras no Brasil. Dentre esses destaco os trabalhos de Martins, Oliveira e Iokoi170 que, com abordagens diferentes, trataram do assunto.

A ausência da mediação do Estado em certos momentos, como na demora em resolver os problemas fundiários, e sua ação truculenta, em ocasiões como nos despejos, só agravou o problema. Fazendeiros enfrentavam - e ainda enfrentam - diretamente posseiros, parceiros, meeiros, trabalhadores rurais, bóias-frias... Grupos excluídos entravam - e ainda entram - em conflito entre si. Um contato com um pouco desse universo é estabelecido por meio da fala de Daniel:

Tem muita gente que é sem terra, mas não sabe por quê. No passado, seus pais, seus avós eram donos de pequenas

\footnotetext{
${ }^{168}$ MARTINS, Op. Cit., 1985, p. 23/24.

${ }^{169}$ BOFF, L. Responder Florindo: da crise da civilização a uma revolução radicalmente humana. Rio de Janeiro: Garamond, 2004, p.53.

${ }^{170}$ Referências completas na bibliografia.
} 
propriedades e foram expulsos das terras que tinham. Isso foi o que aconteceu comigo. Meu avô e meu pai eram pequenos agricultores. No Rio Grande do Sul, tem uma reserva que é dos índios e eles foram expulsos de lá pelos índios mesmo. Naquela época, eles não tinham como recorrer a nada, porque a terra era dos indios mesmo.

Vários casos de ocupação irregular de terras ficaram famosos e marcaram o surgimento do Movimento Sem Terra em diversas partes do país. ${ }^{171}$ Um dos mas conhecidos ocorreu em 1978. Foi o conflito entre os índios Kaigang e os colonos do Rio Grande do Sul que viviam nas terras da reserva indígena de Nonoai. ${ }^{172}$

De qualquer modo, os enfrentamentos tornaram, e ainda tornam, a questão agrária, "caso de polícia". Nas palavras de Aquiles:

Quando chegamos no assentamento nosso para conseguir a reforma agrária, o que a gente via era a polícia e pistoleiro armados, contra os pequenos, e que não podiam estar armados. A polícia chegava e desarmava o pequeno e deixava os pistoleiros que estavam junto com eles armados. Eu achava que a gente tinha que tomar uma providência, trabalhar para estar comprando armas de grande porte para enfrentar. Arma para enfrentar arma. Depois a gente foi ver que não. Que tem que ter gente para enfrentar as armas. Naquele tempo, cheguei a enfrentar pistoleiro... sem arma...

Muitas outras referências a esses enfrentamentos entre policiais e manifestantes são apresentadas por Aquiles, quando ele fala, por exemplo, dos atos públicos, ocupações ou manifestações em torno da luta pela terra que marcam o mês de abril, que por essa razão, no ano de 2005, recebeu a alcunha de "Abril Vermelho". Cabe explicar que abril é o mês escolhido pelos movimentos sociais rurais como símbolo da luta no campo dada a importância para os sem-terra do dia 17 de abril, pois:

Em 1996, mais de três mil famílias ocuparam a fazenda Giacomet e formaram um acampamento do MST no maior latifúndio do Paraná; no mesmo dia dezenove sem-terra

\footnotetext{
${ }^{171}$ Sobre o assunto fiz um balanço no capítulo Trajetória do MST, de minha dissertação. RIBEIRO, S. Op. Cit, 2002.

${ }^{172}$ Sobre o assunto ver MARCON, T. Acampamento do Natalino: história da luta pela reforma agrária. Passo Fundo/RS: Ediupf, 1997 e RIBEIRO, S. L. S. Op. Cit, 2002, p.53.
} 
foram mortos pela Polícia Militar do Pará, na chamada "curva do S" da Rodovia PA-150, nas proximidades de Eldorado dos Carajás. Em 17 de abril, um ano depois, terminava em Brasília a Marcha Nacional por Reforma Agrária, Emprego e Justiça, uma caminhada de dois meses que começou em três pontos do território brasileiro - São Paulo, Governador Valadares e Rondonópolis -, percorreu mais de três mil quilômetros e tomou as avenidas da capital do país em manifestação no dia que se tornou data internacional de luta pela reforma agrária. 173

Mas se esse é um mês de intensificação das manifestações, é também um período em que a atuação da polícia é mais forte, tanto por atuar na defesa da propriedade privada, quanto por atuar na defesa dos interesses de quem a possui. É por essa razão que Aquiles faz referência às represálias sofridas no mês abril:

Agora, um ano atrás, no "Abril Vermelho" tivemos a casa nossa, da regional Oeste quebrada. A gente dentro da cidade e a polícia não fez nada. $\dot{E}$, tivemos acampamento queimado... mataram um companheiro nosso... Não foi com tiro. Era uma hora da manhã quando os pistoleiros chegaram e começaram queimando, batendo em gente. Esse companheiro tinha pressão alta, acho que subiu e ele acabou morrendo... A polícia até hoje não fez nada. Foi muito complicado. E a gente sabe que tem que estar caçando uma forma de organizar porque cada dia que passa os fazendeiros estão se organizando.

Muito embora as críticas à ação da polícia sejam constantes, muitas vezes repontam nas entrevistas argumentos em defesa dos policiais, ou mesmo uma crença de que os soldados da base policial têm muito em comum com as pessoas que compõem as fileiras de uma manifestação como a Marcha. A fala de Ana Paula lembra disso:

Quando a gente ia marchando tinha uns policiais que perguntavam: de onde a gente era? Por que a gente estava ali? Sorriam, faziam um gesto... Apesar de serem mandados, a gente percebia que muitos deles ali são a favor do MST.

\footnotetext{
${ }^{173}$ CHAVES, Op. Cit., 2000, p.34.
} 


\section{Mais recentemente,}

o Movimento assumiu uma posição oficial frente ao uso de armas, inclusive apoiando a campanha de desarmamento realizada pelo governo federal e fazendo campanha em prol da proibição do comércio de armas de fogo e munição para particulares, no referendo popular de 2005, realizado

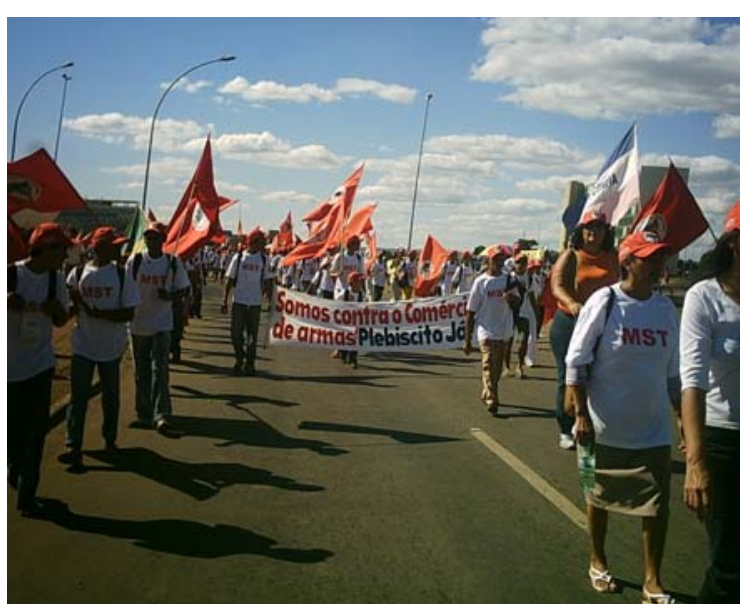

Marchantes carregando faixas pedindo o plebiscito e expondo o posicionamento do MST.

pelo Tribunal Superior

Eleitoral - TSE - em todo

território brasileiro.

Mesmo aceitando a definição central do Movimento, militantes como Aquiles apresentam suas críticas:

A polícia federal não desarmou os ricos, desarmou os pobres que tinham espingarda velha. $\mathrm{Vi}$ em Salvador várias espingardinhas velhas que a polícia recolheu e não recolheu as principais armas que está na mão dos fazendeiros, que permanecem matando gente. Então, depois da campanha do Governo Federal de desarmamento, a gente teve perda de mais de oito trabalhadores, no Brasil, do Movimento Sem Terra. Matado por fazendeiros e a gente sabe que não somos nós que estamos armados e que nem a justiça nem o Governo vai fazer nada para desarmar esses trapaceiros que andam por aí fazendo o que faz com a família que luta por um pedaço de chão.

Durante o evento que marcou o final da marcha, no dia da manifestação na Praça dos Três Poderes, ocorreu um conflito entre os manifestantes e a policia. A imprensa registrou a desavença e a publicou nos jornais do dia seguinte. O que pude presenciar foi que os flashes das câmeras fotográficas foram responsáveis pelo agravamento da situação. Manifestantes que estavam distantes, e nada sabiam do 
conflito, ao ver todo aquele movimento, corriam curiosos em sua direção, com a certeza de que suas expectativas se concretizavam. Alguns falavam em meio à multidão: "É o Lula!", "Ele veio falar com a gente!". Para muitos, esse seria o desfecho esperado. Cabe lembrar que todos tinham caminhado muito para estar ali. Além disso, Lula não representava um presidente comum, muitas vezes é visto como um igual, além disso esse foi o homem que em sua posse abraçou manifestantes e rompeu com protocolos de segurança do Palácio do Planalto. Muitos dos presentes achavam possivel que ele viesse à praça receber a marcha.

O resultado disso foi que policiais a cavalo, para acabar com o conflito, avançaram sobre a multidão, machucaram algumas pessoas e causaram um grande tumulto. Entre os que vinham para "ver o presidente" e os que corriam dos policiais, algumas crianças e várias pessoas perdidas, não sabiam o que deviam fazer, nem para onde correr. Um helicóptero com soldados armados voava bem baixo sobre o local. Assim, muitos, amedrontados, foram embora antes do fim da programação. É sobre isso que Ana Paula refere-se em sua entrevista quando falou:

Porque a gente sabe que estava fazendo uma manifestação passiva. E como que os caras reagiram?! Isso foi já uma coisa planejada, pensada, dá para perceber a provocação que fizeram. A gente percebe o quanto eles estão articulados, o quanto nós temos que nos organizar para não cair nessas provocações e o quanto a gente falhou. Isso marcou de forma negativa pelo fato de que em toda a trajetória da marcha, fizemos tudo certinho. Apesar de toda aquela coisa bonita que a mídia mostrou, no final fechar com isso, a imagem do Movimento. E isso é muito ruim para nós.

Ana Paula lamenta que o evento tenha terminado dessa forma. Mais uma vez a imagem do Movimento podia ser associada à violência e à baderna. O significado da marcha e da ação do MST foi misturado a um turbilhão em que se desqualificava a luta pela cidadania. Para os telejornais daquela noite e toda a produção da mídia no dia seguinte, esse foi assunto de "primeira página". A 
violência, mais uma vez, se fez presente no cotidiano de quem busca a inclusão.

\section{Semente no campo da inclusão}

A possibilidade de inclusão aberta pela participação no MST ganha dimensão e importância quando se lê uma entrevista como a de Wanderléia que inicia contando a história de como conheceu o MST e o quanto isso mudou sua vida.

Bom, me chamo Wanderléia, sou do Rio de Janeiro. Morava em Japeri, e conheci o Movimento através de vizinhos, que eu tinha... Sofria muito antes de conhecer o Movimento, meu marido estava desempregado. Eu era doméstica, às vezes tinha trabalho, às vezes não. Tinha três filhos, passava muitas necessidades. Meu marido ficava atrás de emprego, saía de manhã, voltava à noite com fome, cansado, e não tinha nem o que dá para os filhos comer. A gente vivia muito apertado... Eu já estava em pânico, quando um vizinho me falou do Movimento, do MST, me convidou para participar de uma reunião.

A exclusão também pode ser percebida nas diversas passagens em que os narradores contam o cotidiano de violência no qual tiveram que conviver.

Tem coisa que aconteceu que talvez são difíceis. Não só para mim, mas para um certo grupo de pessoas. Por exemplo, quando a gente fala dos despejos, que aconteceram na nossa região nos últimos tempos que foram bastante violentos... Ninguém quer viver aquilo. $O$ que aconteceu num dos despejos nossos, foi à polícia dando muito tiro no meio de homens, de mulheres, de crianças, de velhos e tirando duzentas famílias de uma área que tu tinha certeza de que era improdutiva. Tinha consciência que era de uma pessoa, que se dizia proprietário, e que não depende dela para viver, nem para nada. Nem para explorar. Mas não basta dizer "não quero viver mais", e desistir, tem que lutar. Porque senão vai acontecer de novo. Mesmo lutando vai acontecer de novo, em outras áreas. Mas lutando pode ser que chegue o dia que não aconteça mais. (Adelir) 
Invisibilidade é outro tema importante, que marca a exclusão e o trauma. De maneira geral, existe uma apropriação de temas, por determinados grupos, como se mais nenhum grupo tivesse vivido algo semelhante ou que o trauma pudesse ser mensurado como mais ou menos intenso. Esvazia-se o trauma de outros a ponto de torná-los silenciosos. Esse é um processo de enquadramento, pelo qual a memória de uma sociedade pode passar. Segundo Pollak, esse "enquadramento da memória" provoca o silenciamento de grupos, (que sofrem exclusão ou perseguição). ${ }^{174}$ Isso é o que por vezes gera a invisibilidade de ações de movimentos sociais, que tentam romper o silêncio.

A memória, essa operação coletiva dos acontecimentos e das interpretações do passado que se quer salvaguardar, se integra, como vimos, em tentativas mais ou menos conscientes de definir e de reforçar sentimentos de pertencimento e fronteiras sociais entre coletividades de tamanhos diferentes: partidos, sindicatos, igrejas, aldeias, regiões, clãs, famílias, nações etc. A referência ao passado serve para manter a coesão dos grupos e das instituições que compõem uma sociedade, para definir seu lugar respectivo, sua complementariedade, mas também as oposições irredutiveis. ${ }^{175}$

Para relacionar a exclusão com idéia de trauma é preciso lembrar de uma seqüência histórica do Brasil, que se inicia com a colonização e a formação do latifúndio, se desdobra na exclusão do índio e no uso da mão-de-obra escrava negra. A opção mercantilista da escravidão favoreceu poucos, ao mesmo tempo em que excluiu muitos. Elementos que somados a fatores de continuidade de uma história de exploração geraram no presente a pobreza, a concentração de renda, o preconceito e a desigualdade social. Desigualdade esta que sustenta a situação de exclusão desses sem-terra.

A exclusão, a desigualdade, são sintomas de uma situação de exceção. Estar no espaço da absoluta exceção, segundo Agamben, é extremamente traumático, pois "é este espaço de exceção, no qual o

\footnotetext{
${ }^{174}$ POLLAK, Op. Cit. 1989, p. 7.

${ }^{175}$ Idem, ibidem.
} 
nexo entre localização e ordenamento é definitivamente rompido". ${ }^{176}$ A desordem absoluta traz consigo a falta de sentido, assim não é possivel que cada pessoa entenda onde está e organize sua lógica, pois tudo é arbitrário e sem limites. A falta de perspectiva de mudança dessa situação torna esse cotidiano traumático.

Toda vez que ouvia essas histórias, ao mesmo tempo em que me sentia sensibilizada, me sentia mal, por pertencer a uma classe social distinta que, mesmo nascida em um país de maioria da população pobre, pôde estudar e ter acesso a uma vida diferente. Sentir-me desta forma conduziu-me a uma ação. A ação possivel nesse momento se traduz na escritura desta tese. Mas no decorrer da pesquisa significou um envolvimento com projetos educacionais do MST, o que proporcionou um afastamento de algumas certezas - por vezes preconceituosas e etnocêntricas - e possibilitou a construção de novos referenciais particulares e o entendimento de outros contextos. Nesse processo, pude sentir-me "descolonizando" a mim mesmo.

Em todas as entrevistas estive aberta a conhecer esse mundo novo com o qual não me relacionava antes. A experiência de entrevistar mudou também a entrevistadora que no mínimo pode dizer que ampliou seu mundo.

\section{Narrativas testemunhais}

Essas tramas que contam sobre a exclusão social, a convivência com o autoritarismo, com a perseguição política e exploração econômica conduziram a uma reflexão sobre testemunhos. As narrativas que ora se apresentam são cotidianas e testemunhais. Como as presentes nos livros Me llamo Rigoberta Menchú y asi me nació

\footnotetext{
$\overline{{ }^{176} \text { AGAMBEM, Op. Cit, 2004, p. } 27 .}$
} 
la conciência, ${ }^{177}$ Se me deixam falar ${ }^{178}$ e Memórias de um Cimarron. ${ }^{179}$ São testemunhais, pois têm o sentido de transpor a dor e a exclusão. Esse é seu caráter específico. Por meio delas o narrador quer reestabelecer-se e buscar a justiça.

Torna-se importante enfrentar a questão sobre a veracidade do livro escrito por Burgos, encabeçadas por David Stoll,180 que apontavam críticas com relação aos "erros" e ocultações de seu testemunho. Essas críticas fizeram com que eu refletisse sobre a produção dos testemunhos e (auto)biografias populares como gêneros específicos, que mereciam cuidados especiais. De qualquer maneira, gostaria apresentar a defesa formulada pelo próprio comitê que outorgou o prêmio Nobel à Rigoberta: "toda autobiografia se adorna hasta cierto ponto". E de acordo com Lienhard:

Sin duda, tanto Rigoberta como el Instituto Nobel tienen toda la razón em cuanto al trasfondo político del asunto y el carácter parcial, em los dos sentidos de la palabra, de la investigación de Stoll. ${ }^{181}$

Testemunhos devem ser considerados textos plurais, um coral de vozes, que narram memórias individuais e coletivas em torno de sua luta politica, ou seja, ao testemunhar, se organiza um discurso, que por ser ação, marca uma posição do sujeito em busca da justiça.

Nesta tese, trata-se de narrativas que nasceram da experiência de pessoas que buscam representar situações históricas determinadas, pelas quais elas (ou outras pessoas) passaram, marcadas pela extrema violência e que exigem uma narração. Segundo Seligmann-Silva, essas narrativas, paradoxalmente, visam não só o 'esquecimento' (o afastamento da dor) mas também um tratamento formal histórico e jurídico.

\footnotetext{
${ }^{177}$ BURGOS, E. Me llamo Rigoberta Menchú y así me nació la conciência. Barcelona: Argos Vergara, 1983.

${ }^{178}$ VIEZZER, M. Se me deixam falar... Domitila - Depoimento de uma mineira boliviana. São Paulo: Ed. Global, 1984.

${ }^{179}$ BARNET, M. Memórias de um Cimarron: testemunho. São Paulo: Marco Zero, 1986.

${ }^{180}$ STOLL, D. Rigoberta Menchú and the story of all poor Guatemalans. Boulder: Westview Press, 1999.

${ }^{181}$ LIENHARD, M. Los testemonios populares y la cuestión de su lectura. Cuadernos de Literatura, vol.38, La Paz: Casa montes, 2001, p. 8.
} 
... o testemunho deve ser compreendido tanto no seu sentido jurídico e de testemunho histórico - ao qual o testimonio tradicionalmente se remete nos estudos literários - como também no sentido de "sobreviver", de ter-se passado por um evento limite, radical, passagem essa que foi também um "atravessar" a "morte", que problematiza a relação entre a linguagem e o "real". De modo mais sutil - e talvez dificil de compreender - falamos também de um teor testemulhal da literatura de modo geral: que se torna mais explícito nas obras nascidas de ou que tem por tema eventos-limite. ${ }^{182}$

Seguindo as reflexões apresentadas no livro organizado por Seligmann-Silva, no presente trabalho gostaria de sinalizar a possibilidade de pensar o conceito de narrativas nascidas de experiências traumáticas para além dos estudos da Shoah e do testimonio na América Latina.

O século XX foi marcado por grandes conflitos e catástrofes dentre os quais o Holocausto se destaca. Mas gostaria de referenciar que em seus últimos anos viveu-se o fim o Apartheid, o que trouxe a público todo o horror da segregação na África do Sul, e fez com que muitos repensassem o trauma da colonização africana que gerou a escravidão e a exploração da população de um continente. O início do século XXI mostrou que o século anterior tinha deixado tristes heranças. Os conflitos ainda não resolvidos, como as guerras civis que produziram e produzem refugiados na África, na Ásia e no leste europeu. O terrorismo que não sem razão amedronta países mais ricos. O 11 de setembro fixou-se na memória de todo o mundo e traumatizou a população estadunidense. Outros ataques fazem com que o terror não seja esquecido.

Com esse cenário em mente, e os estudos provocados por ele, evoca-se as reflexões de Ferreira, sobre projetos testemunhais :

Quais seriam os pontos comuns entre os projetos testemunhais da atualidade? Um primeiro ponto em comum é a utilização da oralidade como instrumento político para recuperar a memória de massacres. Através do registro de depoimentos orais busca-se oferecer às vítimas a possibilidade

\footnotetext{
182 SELIGMANN-SILVA, M. (org). História, memória, literatura: o testemunho na Era das Catástrofes. Campinas: Ed. Unicamp, 2003, p.8.
} 
de perpetuar as suas memórias. Assim, além de possibilitar a publicidade de uma narrativa que muitas vezes seria obliterada pelos discursos oficiais, tais projetos visam também a uma espécie de catarse social, muitas vezes com o objetivo de obter a pacificação de conflitos imediatos... ${ }^{183}$

Ao unir as reflexões desses autores propõe-se a própria aplicação do conceito de testemunho de forma que possa ser entendido como um discurso do "sobrevivente" que precisa narrar sua história como forma de se recompor, de saber quem ele é. Narrar o trauma é algo necessário para tais pessoas. O trauma narrado é revivido e resignificado, fazendo com que o "fluxo (encantado) da narrativa" possa carregar a dor para longe. Ao ser retrabalhado, este trauma expresso na narrativa representa a vontade do sujeito de marcar com suas palavras a resistência e a busca por justiça, após ter sobrevivido a tanta injustiça.

Entretanto, como bem alertou Ferreira, não se pode pensar no testemunho, e nos projetos desenvolvidos com base neles, de forma ingênua:

... talvez seja elucidativo deixar claro que a memória em si, não é boa nem má. Muitas vezes os beneficios que se procura extrair dos projetos testemunhais podem ser desvirtuados devido às formas assumidas pelas rememorações. Pode-se lembrar de uma violência com o objetivo de evitar sua repetição, porém pode-se acionar essa mesma memória para justificar vinganças violentas no presente. Tal é o princípio dos revanchismos sociais, que estão longe de favorecer um apaziguamento de conflitos. ${ }^{184}$

No caso de grupos como o dos membros do MST entrevistados para esse trabalho, essa luta politica tem plataforma definida, o que fica claro na leitura de suas narrativas. A busca de cidadania é carro chefe dessa luta. Os processos de identificação são parceiros dessa "cidadanização". Isso pode ser notado nas palavras de narradores como Wanderléia ou Aquiles, que apresentam sua entrada no MST, como

${ }^{183}$ FERREIRA, M. M. Oralidade e memória em projetos testemunhais. In: LOPES, A.H., VELLOSO, M. P., PESAVENTO, S. J. (orgs.) História e linguagens: texto, imagem, oralidade e representações. Rio de Janeiro, Edições Casa de Rui Barbosa e 7 Letras, 2006.

${ }^{184}$ Idem, 199. 
formadora de si. É a partir daí que passam a existir, a sentir-se gente e a significar sua vida. Ou seja, a militância lhes deu segurança e foi a saída, não só para o narrar, mas para o viver.

As relações entre o antes e o depois da entrada no Movimento, entre discurso pessoal e discurso militante se fazem presentes o tempo todo. É mostrando causa e conseqüência que as narrativas parecem fazer sentido. Assim Wanderléia, parece afirmar que só é suportável lembrar de tudo aquilo acontecido no passado, porque o presente é diferente. E aqui é importante explicar o que é diferente. A situação material melhorou um pouco, mas o ter não é o suficiente para marcar a mudança. O que parece relevante é a transformação do sentir-se. É no ser que a diferença se define. Em um novo ser, com uma identidade de grupo, mais autoconfiante, que ao narrar sua história reafirma sua agência. É olhando por esse prisma que se pode entender a afirmação:

Aqui na marcha a gente reparte. No nosso acampamento é repartido tudo, pode ser um quilo de arroz, um quilo de fubá... Quando o governo demora para mandar alimentação, passava tempo de pegar um quilo de fubá botar no panelão, para fazer uma água de fubá para todo mundo. Mais de 100 famílias comer! Ficava aquela água suja, porque não tinha outra coisa para poder sobreviver e agüentar a luta. Já passamos isso.

Como apresentou Lasch ${ }^{185}$, em uma reflexão sobre a sociedade estadunidense, atualmente pode-se perceber no cotidiano da sociedade contemporânea uma superação das lutas e conquistas coletivas pelas expectativas e aspirações individuais e imediatas. Investe-se em "auto-crescimento psíquico", e as "grandes causas comuns da humanidade" passam a ser emblemas de três décadas atrás.

No geral, atualmente, ser membro da comunidade é ser um indivíduo que trabalha exercendo suas funções estabelecidas, ganhando dinheiro e consumindo. Quanto maior o poder aquisitivo de um indivíduo, maior é seu grau de inserção social, ou seja, é membro de destaque da comunidade, é mais cidadão.

\footnotetext{
${ }^{185}$ LASCH, C. A cultura do narcisismo: a vida americana numa era de esperanças em declínio. Rio de Janeiro; Imago Editora, 1983.
} 
As pessoas que estão na fronteira emprego/desemprego e, portanto, pendendo entre ser ou não membro dessa comunidade vivem em uma posição pouco confortável, tentam sobreviver e não têm acesso a seus direitos. A sociedade constantemente está produzindo formas de exclusão e discriminação.

Uma importante mensagem passada por essas entrevistas é a tentativa de superação dessa exclusão. Pode-se dizer que o MST age como agregador de um grupo acerca de um ideal - o ser - e luta pela a conquista da terra - o ter. A busca por uma condição, que de alguma forma foi negada - a procura por ser e por ter algo - é o que leva essas pessoas para a luta coletiva.

Wanderléia expressou o seguinte pensamento: "Sei que o Movimento proporciona muita coisa boa. Antes quando estava fora do Movimento não me sentia uma brasileira, uma pessoa importante, eu me sentia... nada!...".

Até mesmo uma identidade de nação se forma a partir da participação ativa em um grupo. Wanderléia coloca em destaque que antes de entrar para o movimento não se sentia cidadã, não sabia o que significava ser brasileira, e por isso não se sentia como tal. Sentir-se importante no presente mostra uma conscientização de uma situação anterior de exclusão, portanto aparece em oposição ao como ela hoje vê sua situação no passado. Wanderléia define com segurança "O Movimento resgatou minha dignidade!". Importante lembrar que essa situação de exclusão para Wanderléia culminou em uma tentativa de suicídio que foi narrada com muita dor.

A dignidade referida está relacionada a uma "nova pessoa" que se forma a partir da entrada no Movimento e que tem uma perspectiva de futuro, que sonha, que tem amigos e pode conversar com eles.

[No movimento] A gente tem chance de aprender, de compartilhar o seu sofrimento com outras pessoas. Pode conversar com elas. Se por algum motivo levanta de manhã e está de mau humor, ou angustiado com alguma coisa, os companheiros chegam, conversam... [...] Ensina as coisas e dá a chance para ser alguém. Se o que a pessoa não sabe é ler, 
ensinam a ler, dá chance para ser alguém na vida. Veja, jamais eu poderia estar aqui em Brasília, sou do Rio de Janeiro, qual movimento que poderia fazer isso? Me trazer até aqui. Quando poderia conhecer Brasilia? Como? Jamais poderia conhecer Brasília. Estou aqui. Graças a quem?

Nisso reside a força implícita desse movimento social. Não é exagero, para Wanderléia, afirmar que o MST salvou sua vida. Nossa colaboradora, portanto, assume essa identidade de forma profunda, pois ela representa uma possibilidade de vida digna. Segundo as narrativas construídas a entrada no MST, portanto, é uma semente plantada no campo da inclusão.

\section{Tornar-se cidadão}

A trajetória que precede a entrada no Movimento consistiu em uma vivência traumática, marcada pela condição de despossuído (no fato de não ter terra, mas também não ter emprego, escolarização ou condições dignas de vida). Ou seja, a essas pessoas não foi permitida a cidadania plena e seus direitos não foram reconhecidos ou garantidos pelo Estado. Paradoxalmente, é na luta por esse reconhecimento e por sua efetivação que uma cidadania é conquistada.

A entrada no movimento social marca como seus participantes sentem a conquista de sua cidadania. O Brasil não tem tradição de luta por direitos, em geral eles foram legalizados pelo Estado. "O processo de construção da cidadania enquanto afirmação e reconhecimento de direitos é, especialmente na sociedade brasileira, um processo de transformação das práticas sociais enraizadas na sociedade como um todo."186

Cabe expor aqui uma reflexão elaborada por Roseli Salete Caldart, membro do setor de educação do Movimento dos Sem Terra ao dizer que o intuito do MST é educar cidadãs e cidadãos do seu tempo:

É bem verdade que a palavra 'cidadão' é ainda parcial, à medida que remete à cidade. Seria o caso de inventarmos uma

\footnotetext{
${ }^{186}$ DAGNINO, E. Os movimentos sociais e a emergência de uma nova noção de cidadania. In: Os anos 90: política e sociedade no Brasil. São Paulo: Brasileiense, 1994, p.109.
} 
nova palavra, que tenha o mesmo sentido, mas que faça referência aos moradores do campo? Ou deveríamos recuperar o sentido da palavra camponês? ${ }^{187}$

Ou ainda, como apresentado por Paladim Júnior:

Será que o que se delineia a partir do que esse estudo revela não poderia ser denominado de campesinia? [...] os assentamentos são lugares de construção e/ou reconstrução de relações sociais e de possibilidades de ser cidadão, camponeses e agentes de transformação da sociedade brasileira. Campesinia seria a cidadania camponesa. ${ }^{188}$

Muitas entrevistas mostram como essas pessoas sentem sua transformação, contando as mudanças de atitudes ocorridas em suas vidas após a entrada no Movimento dos Sem Terra. Fica evidente na fala de pessoas como Wanderléia o sentido de luta que encontrou. Sua narrativa mostra que por meio desse processo a família recebeu nova significação e o indivíduo ganhou força ao enxergar-se agente social ativo. Com isso, um novo conceito de cidadania passa a ser desenhado, que não se vincula a uma estratégia de governo.

A nova cidadania requer (e até é pensada como sendo esse processo) a constituição de sujeitos sociais ativos definindo o que eles consideram ser os seus direitos e lutando pelo seu reconhecimento social e político. Nesse sentido, ela é uma estratégia dos não-cidadãos, dos excluídos, uma cidadania "de baixo para cima". 189

As mudanças são muitas. A entrada num movimento social representa um salto qualitativo no padrão de vida. Pessoas que antes viviam em favelas na cidade conquistam um espaço para morar e passam a refletir sobre sua própria condição anterior. Para os narradores a entrada para o MST simbolizou o retorno ao convivio

\footnotetext{
${ }^{187}$ A relevância de colocarmos aqui tal pensamento, é a de mostrarmos que o Movimento dos Sem Terra não apenas discute a idéia de cidadania, mas também questiona a qualidade do conceito aplicado. Ou seja, a reflexão se distância de uma mera repetição dos tradicionais temas da esquerda, mas renova-se ao questionar termos já cristalizados. CALDART, R. S. Educação em movimento: formação de educadoras e educadores no MST. Petrópolis/RJ: Vozes, 1997, p.113.

${ }^{188}$ PALADIM JÚNIOR, H. A. Insurreição dos saberes, territorialização e espacialização do MST: um estudo de caso da Escola Agrícola 25 de maio - Fraiburgo/SC. O ensino de geografia em questão. Dissertação de Mestrado. São Paulo: Dep. de Geografia FFLCH/USP, 2004.

${ }^{189}$ DAGNINO, E. Op. Cit., p.108.
} 
social, às relações de carinho, enfim a condição humana que lhe havia sido roubada.

Em paralelo a essa discussão sobre cidadania cabe agregar a importância de um processo de formação e educação das pessoas do campo. Sobre isso quero destacar a atuação do Setor de Educação do Movimento, que pude acompanhar de perto durante alguns anos. Dessa experiência de acompanhamento resultou a escrita de um boletim de educação intitulado "20 anos de educação"190 em que estão registradas as principais conquistas desse setor, desde a primeira ocupação e o início dos trabalhos com as Cirandas, até a conquista das politicas públicas da Escola Itinerante e da formação dos cursos técnicos e parcerias com universidades para a realização de cursos de nível superior.

As palavras de Stédile, ao falar dos 20 anos do Setor de Educação, enfatizam o quanto essas conquistas foram para o próprio Movimento:

Temos muito a comemorar. Primeiro comemorar a lucidez de termos construído uma consciência de que o acesso à educação era fundamental, para "libertar" as pessoas, como dizia Paulo freire. Libertar da escuridão, da ignorância, da falta de democracia. E também podemos comemorar, como conseguimos engajar milhares de companheiros e companheiras em atividades especificas da educação. E também temos a comemorar muitas conquistas, desde nosso programa de alfabetização de jovens e adultos, nossas escolas técnicas, como o IEJC - Instituto Josué de Castro. Nossos convênios com as universidades brasileiras, nossos programas de pós-graduação. Nossos convênios inclusive com universidades do exterior, que permitem que hoje mais de 60 jovens, sem-terra estejam estudando medicina em Cuba. E que haja outros jovens estudando idiomas em outros países. Temos a comemorar a construção de nossa escola nacional, que depois de cinco anos de verdadeiro mutirão nacional, esta quase pronta, e vai se tornar um centro de ensino superior, para nossos jovens. ${ }^{191}$

\footnotetext{
${ }^{190}$ RIBEIRO, S. L. S (org). 20 anos de Educação. Boletim de Educação do Movimento dos Trabalhadores Rurais Sem Terra, nº 09. São Paulo: MST, 2004.

191 STÉDILE, João Pedro. A história do MST é um aprendizado coletivo In: RIBEIRO, S. L. S. Op. Cit. 2004.
} 
O Movimento com isso tentou e tenta superar o analfabetismo e a baixa escolaridade, um quadro bastante triste que se desenhou principalmente para os moradores do campo brasileiro e que de certa forma, está caracterizado nas histórias de nossos colaboradores. Destaco a narrativa de Wanderléia:

Eu não tinha nem chance de ir para escola. Foi depois de grandona que consegui estudar alguma coisa... fiz até a $5^{\text {a }}$ série, mais ou menos... (...) Fui para escola, tinha uns... uns 13 anos, mas aquela coisa assim... Entra na escola e sai porque tem que mudar de fazenda. Nunca consegui aprender nada!

\section{Wanderléia}

De forma geral, mesmo com as significativas melhoras em termos da abrangência da educação básica e do ensino fundamental, no campo, quem realmente quer estudar tem que fazer grandes sacrificios. E nesse sentido ainda há muito por fazer para superar a situação que Ana Paula descreveu sobre sua mãe:

Todo sábado, ela tinha que pagar passagem para ir até a cidade fazer as provas. Ela estudava a semana inteira e no sábado ia fazer as provas daquele conteúdo. Então, um detalhe bem interessante é que para minha mãe para sustentar a gente e pagar essas passagens tinha que quebrar coco a semana inteira. Cuidava dos filhos, estudava e quebrava coco. A primeira professora do nosso povoado foi ela.

É preciso atentar para a consciência que esses narradores apresentam. O testemunho é um ato político que ao demonstrar em palavras sua preocupação com a educação para formar um cidadão mais participante, forma, na prática, esse cidadão. Assim, os membros do Setor de Educação trabalham em prol de um processo educativo que pondere a especificidade da educação no campo, para pessoa do campo e por pessoas do campo. Assim, os membros dos movimentos sociais conjuntamente mobilizaram o poder público federal que criou dentro do ministério da educação um departamento para cuidar das questões da 
educação do campo. No primeiro relatório parcial do segundo ano de execução do Programa Brasil Alfabetizado, ${ }^{192}$ pode-se ler:

... entendemos por educação do campo um processo de aprendizagem que aconteça no campo - pois as pessoas têm o direto de estudarem onde vivem; desenvolvido pelos educadores do campo - pensada a partir de sua realidade, com a sua participação e vinculada à sua cultura; e evidentemente para o campo - podendo responder às suas demandas sociais e humanas. 193

Importante ressaltar que a educação é direito do cidadão, conquistado historicamente e, portanto, dever do Estado. No entanto, esse direito ainda não está assegurado para os moradores do campo. Normalmente, a busca por escolas para os trabalhadores rurais e seus filhos esbarra em vários entraves. O primeiro é o geográfico, ou seja, a escola, geralmente, não está no campo. Depois, mesmo quando está lá, raras são as vezes em que foi pensada pelo e para o campo.

Para o Movimento Sem Terra, a “educação do campo"194 se concretizaria por meio da instalação de escolas no campo com um projeto político pedagógico que respeite o imaginário camponês, e que esteja ligada a sua história, aos seus sonhos e seus desafios. Neste plano a escola pensada pelo MST deve ter local e ensino próprios. Caminhando nessa direção é que foi oficializada a politica pública da Escola Itinerante nos três estados da região sul do país. E é por isso que Daniel pode acompanhar seus alunos, em marcha. Nesse tipo de escola a marcha e as atividades desenvolvidas durante esse tempo são consideradas carga horária pedagógica, como explicou Daniel:

\footnotetext{
${ }^{192}$ Associação Nacional de Cooperação Agrícola - ANCA, foi a entidade jurídica ligada ao MST parceira do MEC para a realização desse programa de alfabetização de jovens e adultos nos anos de 2003 e 2004.

${ }^{193}$ Primeiro Relatório Parcial do Projeto de Alfabetização - Convênio ANCA/FNDE - Ações do Programa Brasil Alfabetizado, janeiro de 2004, p. 9.

${ }^{194}$ A ação de movimentos sociais no campo fez com que surgisse a diferenciação entre educação do campo e educação no campo. A educação no campo é uma reivindicação permanente, pois a maior parte das escolas está na área urbana dos municípios. A educação do campo, no entanto, representa algo que vai além, é a demanda por uma política pública: uma educação que aconteça in loco e valorize os sujeitos e o modo de vida rural. Foram importantes passos para a concretização desta política pública a criação do Grupo Permanente de Trabalho de Educação do Campo (GPT Educação do Campo), no âmbito da estrutura da SECAD/MEC (Secretaria de Educação Continuada, Alfabetização e Diversidade do Ministério da Educação) e a implementação das Diretrizes Operacionais para Educação Básica do Campo (CNE/CEB nº1. 3/04/02), aprovadas pelo Conselho Nacional de Educação a partir do diálogo com movimentos sociais.
} 
Por exemplo, quando a gente chegar da marcha, vamos assinar o livro do ponto e essas crianças daqui também que vão ter o caderno, e no diário de classe vai estar anotadas as atividades. Conta como aula normal esse tempo da Escola Itinerante na marcha.

Daniel descreve o funcionamento da escola, no Rio Grande do Sul, primeiro estado em que foi oficializado esse tipo de ensino:

Prestamos contas para a escola base, e ela presta conta para a $27^{\text {a }}$ Coordenadoria de Educação que é de Canoas. Isso todo final de ano. As aulas são de janeiro a janeiro, não tem férias. Por esse motivo de ser itinerante. Em tempos de ocupação tem que mudar a aula. A criança sai, vai para base, fica três dias, volta... Só final de ano que a gente tem uma liberaçãozinha de quinze, vinte dias. É dada liberação massiva para o pessoal ir para base, passar Natal, final de ano, e a gente também é liberado. Mas a gente reveza porque tem gente que continua no acampamento: algumas crianças ficam e elas não podem ficar sem aula. Daí um educador fica o Natal, e o outro, o Ano Novo. Tem dado certo. Às vezes alguém fica de cara virada, mas é feita a discussão, se a maioria aceitou... A gente vive no coletivo tem que aceitar.

As relações entre o estudante, o local e o modo com que o processo educativo é realizado fazem parte de uma formação identitária que tenta marcar um vínculo com o campo e a valorização da experiência do trabalho com a terra. Assim, para o Setor de Educação é fundamental legitimar a busca por políticas públicas que priorizem a formação desse homem do campo. É com esse objetivo claro que Elizandra chega a dizer:

Gosto muito do trabalho que eu faço dentro do Movimento, porque é em busca, como diz Paulo Freire, de uma educação libertadora. Uma educação diferente desse modelo educacional da nossa sociedade. É nas escolas da cidade que querem colocar as crianças do campo, não respeitando as diferenças, a identidade do povo camponês.

Afirmar uma identidade camponesa, diferente de uma urbana é o que legitima a existência de um cuidado do poder público específico para com esta comunidade. Este é o argumento para a luta por escolas nas áreas rurais visando atender as crianças que lá moram, pois na 
maioria das vezes as escolas se localizam em áreas urbanas. As crianças, portanto, participam de manifestações pela conquista do direito ao estudo, reinvidicando transporte para a cidade, ou indo além, conquistando as escolas do campo. Esta não é questão simples, porque instalar escolas no campo é algo que reconhece o direito de minorias e coloca em cheque um modelo urbano de desenvolvimento e progresso para o país.

A luta por direitos e mudanças também afeta os pequenos e isso justifica a existência de marchas e atos públicos em que os personagens principais são os chamados "sem-terrinhas". Ao mesmo tempo dá esperança de continuidade de estudos a jovens como Aquiles, que quer ser advogado, e Daniel, que quer um "monte de coisas", mas faz planos para fazer um curso de magistério ou de pedagogia em escolas vinculadas ao Movimento, como o Iterra. ${ }^{195}$

De forma geral, o que gera espanto em pessoas fora do Movimento, é que uma pessoa de origem pobre almeje se tornar um advogado ou mesmo queira continuar a estudar. Isso é algo que por muito tempo foi impensável para esse grupo social. Estudar e ter um curso universitário era um luxo e não uma possibilidade de crescimento pessoal e afirmação do grupo.

Esses membros do MST, ao darem passos nessa direção, ocupam espaços antes reservados a outros grupos, ampliam seus horizontes e incluem-se no espaço democrático re-significando o mundo em que vivem. Assim, a educação é uma forma de suplantar barreiras, e faz parte de uma estratégia de mudança social.

Estratégia essa que tem outra base nas manifestações públicas e na pressão política. Tem-se, no entanto, que atentar até que ponto o fato de sair às ruas faz com que as demandas desse grupo sejam ouvidas como expressão de um cotidiano democrático. Caso contrário as manifestações sociais apresentam-se apenas "como um

195 O Iterra - Instituto Técnico de Capacitação e Pesquisa da Reforma Agrária - é a instituição mantenedora do Instituto de Educação Josué de Castro - IEJC. Essas instituições mantêm uma parceria e um compromisso com o projeto político e pedagógico do Movimento dos Trabalhadores Rurais Sem Terra e tem sua sede e funcionamento atual no município de Veranópolis, Rio Grande do Sul. 
ruído de corpos sofredores irritados, ruído que a intervenção da autoridade pública deve fazer cessar."196

Rancière ao desenvolver a idéia de que o consenso é a supressão da política e que apenas leva em conta as opiniões enunciáveis, diz que, dessa forma, acaba-se por excluir toda a parcela da população que não participa ativamente do mesmo pensar político, mas que não teve condições de enunciar sua plataforma.

... o consenso suprime todo cômputo dos não contados, toda parte dos sem-parte. Ao mesmo tempo pretende transformar todo litígio político num simples problema colocado à comunidade e aos que a conduzem. Pretende objetivar os problemas, determinar a margem de escolha que comportam, os saberes requeridos e os parceiros que devem ser reunidos para a sua solução. Disso supõe-se decorrer a composição dos interesses e das opiniões no sentido da solução mais razoável. 197

É a presença de tais manifestações que mostra haver uma relação entre o público do debate e da fala e o privado do trabalho e das necessidades, obrigando a discussão e a argumentação, criando assim um mundo comum. O conflito refere-se à constituição desse mundo comum, diz respeito ao que nele se vê e ouve. Todavia, para a criação desse mundo, e para que ele faça sentido para todos os envolvidos, é necessário um alargamento dos horizontes. Saber o quê e como falar. Por isso mesmo, os colaboradores dessa pesquisa se mostraram tão atentos durante as entrevistas.

A direção do MST fala de interesses maiores para a sustentação da luta camponesa, não mais se busca apenas a posse da terra, mas também uma estabilidade na vida rural e melhores preços dos produtos agrícolas no mercado por meio de financiamentos com juros menores. Isso proporcionará vantagens não apenas ao produtor rural, mas afetará toda a população dos que consomem seus produtos.

Pode-se concluir, portanto, que a importância de existir um movimento social como o Movimento dos Trabalhadores Rurais Sem

\footnotetext{
${ }^{196}$ RANCIÈRE, J. O dissenso. In: NOVAES, A. (org). A crise da razão. São Paulo: Cia das letras, 1996, p.376.

${ }^{197}$ Idem, p,379.
} 
Terra vai além da razão social da realização da reforma agrária, da conquista de terras. Ou ainda da razão econômica do aumento da produção e queda dos preços dos produtos; mas é também de fundamental importância política, posto que abrange a criação de um espaço público que discuta questões como inclusão social, educação, cidadania e democracia.

\section{Democracia dissimulada}

Cabe tratar conjuntamente as questões da democracia, da cidadania e das relações existentes entre público e privado, na medida em que se trabalha com pessoas marginalizadas, apartadas da possibilidade de exercerem sua cidadania plenamente e que passam a (re)conquistar direitos, num processo de luta coletiva.

A questão público e privado tem sido amplamente discutida no contexto político atual. As decisões que determinaram e estão determinando a vida social foram e são tomadas em âmbito privado. A "conta" é paga pela sociedade, mas a ela, muitas vezes não é dado o direito ao debate público de tais questões. A relação Estado-sociedade, hoje, não está fundada em bases completamente democráticas, portanto se impõe a necessidade de se disputar um espaço público para discussão de assuntos públicos, para que decisões que devem ser coletivas possam ser tiradas das sombras dos gabinetes trancados.

Bom ressaltar também que na história política recente isso vem se fazendo, e que alguns trabalhos acompanharam essa trajetória do Movimento. Esse é o caso do trabalho de Comparato, ao propor um "estudo do MST a partir da leitura que a imprensa faz das ações do Movimento e do lugar que esse ocupa no cenário político nacional". ${ }^{198}$ Outro trabalho que estudou o envolvimento do MST na politica foi realizado por Santos. ${ }^{199}$ Nessa tese é apontada a parceria do MST em

\footnotetext{
${ }^{198}$ COMPARATO, B. K. A ação política do MST. São Paulo: Ed. Expressão Popular, 2003, p.27. ${ }^{199}$ SANTOS, A. P. Reforma agrária entre a polarização a negociação e o conflito: resistência e participação do MST nos governos do PT do MS e do RS (1999-2002). Tese de doutorado. São Paulo: DH/FFLCH/USP, 2003.
} 
gestões públicas de dois governos estaduais, ou seja, estudou-se a efetiva participação do MST na formulação de politicas públicas e ocupação dos espaços públicos institucionais.

Enfrenta-se assim outro problema. A participação dupla em governos e movimento social fez com que algumas pessoas entendessem a limitação dos governos e, paralelamente, continuassem a exigir seus direitos desses mesmos governos trazendo novas questões para ambas organizações. Assim cindem-se militâncias e surgem problemas. Nas palavras de Santos:

... de um lado, passaram a estar os que participavam dos governos e dos movimentos sociais e, de outro lado, os que participavam apenas dos movimentos sociais. Os primeiros foram aos poucos percebendo as limitações que os governos tinham em termos de recursos financeiros e de estrutura administrativa disponivel para o atendimento das demandas, o que se relacionava tanto com a herança histórica dessas instituições quanto com a conjuntura local, diante da nacional e internacional sob o neoliberalismo. Já os segundos, continuaram a exigir o atendimento das demandas, cobrando as promessas de campanha, muitas das quais passaram a se revelar impossiveis de serem atendidas nas condições que estavam postas. Isso, logicamente, gerou conflitos internos nos movimentos sociais e nos partidos de esquerda, especialmente no MST e no PT. E também originou conflitos entre esses agentes que, pela posição que ocupavam, percebiam de forma diferenciada - e até mesmo divergente as possibilidades históricas de exercício do poder voltado para a realização de conquistas econômicas, socials e políticas que pleitearam ao longo de suas trajetórias. ${ }^{200}$

O Movimento Sem Terra usualmente se caracteriza como de resistência à ordem capitalista estabelecida. Esta caracterização parece coerente, muito embora não se possa afirmar que sua atuação é apenas de resistência. Seus membros participaram efetivamente de algumas gestões e por isso é importante marcar que:

Em que pese as contradições e os conflitos, presentes nos percalços e nas dificuldades com que se depararam (...) estes sujeitos historicamente excluídos do poder puderam, então,

${ }^{200}$ Idem, p.283. 
exercer o poder público em prol do atendimento de demandas históricas dos trabalhadores. ${ }^{201}$

Uma crítica precisa ser colocada às claras: é mais fácil ser visto e se ver como um movimento de resistência, que se envolver como parceiro nas elaborações de políticas públicas de governos, sejam eles, municipais, estaduais ou federal. Dessa forma, o Movimento também se isenta de ser pressionado e até mesmo cobrado a realizar políticas públicas que respondam às demandas específicas do grupo que representa. Isto porque muitas vezes a participação em governos, de cunho mais popular, foi bastante conturbada resultando em uma experiência dificil para os participantes sem-terra que foram envolvidos neste exercício político. Em uma análise da participação do MST nas gestões dos estados do Mato Grosso do Sul e do Rio Grande do Sul, o que se pode perceber, foi que:

... os governos petistas não passaram incólumes pela influência das práticas de poder vigentes, autoritárias e neoliberais, muitas vezes não conseguindo tratar de forma democrática e popular os conflitos que se apresentaram. Tal qual nos governos conservadores, a movimentação popular foi por vezes tida como agente instabilizador do poder e da ordem, não as relacionando com a luta por direitos, por demandas historicamente dadas, percepção que por vezes também se estenderia para ao governo federal petista iniciado em 2003. ${ }^{202}$

Quando esses envolvimentos resultaram em politicas públicas, pode-se dizer que o espaço público e a democracia foram ampliados. Todavia, as heranças de um Estado fechado para a participação popular também foram sentidas. Em alguns casos, mesmo chamando movimentos sociais para a cena principal da disputa política, houve modos de silenciá-los e cooptá-los não respondendo às suas demandas principais e concedendo politicas apenas conciliatórias.

De toda forma, pode-se dizer que a não transparência acaba sendo argumento legítimo para a estabilidade e governabilidade do

\footnotetext{
${ }^{201}$ Idem, p.286.

202 Idem, p.291.
} 
Estado. Há uma disseminação da técnica como modo de governar. Com isso não existe mais crítica. Tudo parece plausivel e se apresenta como a única opção. Ou pura contingência. Um dos resultados dessa estratégia é a não formação do cidadão ciente de seus direitos e deveres, o que prejudica o processo democrático.

Marilena Chauí203 chegou a afirmar, na década de 90, que se vivia no Brasil sob um governo despótico. Esse “déspota” aparecia à medida que se separava ética e politica e se personaliza as qualidades dos governantes. A “arte" de governar passava a ser despolitizar o cidadão. A virtude democrática politica transformava-se. A ética tornava-se moral privada e a política, exercício técnico.

De modo geral, a crítica de Chauí reflete sobre a dificuldade dos governos lidarem com a idéia de conflito e a ação popular, pois esta é tida como agente instabilizador do poder. Desta forma toda e qualquer oposição tende a ser eliminada, não pelo uso da força, mas pelo simples não ouvir ou ainda, ouvir e não tomar nenhuma providência. É aí, no seio da democracia, que se instala, segundo Chauí, o déspota disfarçado, que eleito pelo voto democrático se apropria do espaço público e personalizando o poder.

Sob outro ponto de vista, mas abordando o mesmo tema, Francisco de Oliveira constrói sua argumentação dizendo que alguns regimes ditos democráticos "revelam-se pastiches dos regimes ditatoriais [...] tentam apagar os últimos vestígios de independência e autonomia, numa espécie da cura pelo veneno". ${ }^{204}$ Assim, as questões são postas de lado antes mesmo de serem discutidas. Há um encolhimento da esfera pública frente à regulação do regime. A confecção de um Estado mínimo (para preocupações com o público, mas bastante preocupado com os interesses das grandes corporações) cria uma política social que se resume a caridade e assistência, prestando-se mais ao clientelismo utilitário e à absorção de tensões do

\footnotetext{
${ }^{203}$ CHAUI, Op. Cit.

${ }^{204}$ OLIVEIRA, F. Os direitos do antivalor. Petrópolis: Vozes, 1998, p. 208.
} 
que ao enfrentamento efetivo dos problemas ${ }^{205}$. Desse fato advém a importância da luta política para reverter para o conjunto da população do país o fundo público, que hoje serve o capital.

Ao aproximar o pensamento de Oliveira ao do filósofo francês Rancière tem-se que a dominação se dá quando governantes não dão atenção às demandas da sociedade. É o não ouvir, ignorando o que é falado e reivindicado por movimentos sociais, que faz com que a conversa entre Estado e sociedade seja silenciada. Retomar a fala é o que tem sido feito por parte da luta de movimentos sociais como o Movimento dos Trabalhadores Rurais Sem Terra.

Este contexto de não entendimento mútuo distingue-se do modelo proposto por Habermas, que acredita em uma negociação, em que, Estado e cidadãos partam de pressupostos baseados na razão. Expressando-se por meio de um diálogo no qual as partes interessadas devem chegar a uma idéia de consenso que seja satisfatória para ambas. O acordo comunicativo, fruto da interação desses dois sujeitos, deve ser o objetivo primeiro dessa conversa, e, para isso, todos devem estar preparados para fazer concessões convenientes. Sobre isso Rancière argumenta:

Com efeito, o modelo comunicativo da razão política supõe certa lógica da situação de fala. Dois locutores se vêem confrontados e são levados, pela própria lógica da confrontação, a ultrapassar seu ponto de vista limitado. São obrigados a explicitar as normas que os guiam e experimentar seu caráter contraditório ou não contraditório. São assim levados a universalizá-las tendencialmente e se aproximarem um do outro nesse movimento de universalização. O núcleo dessa lógica é a prova da contradição performativa: se um dos parceiros se recusa a ouvir o que o outro diz ou a justificar o que ele próprio diz, entra em contradição com o que sua posição mesma de discutidor requer, ele próprio não se reconhece como locutor racional. 206

Caso as condições não sejam as propostas pelo pensador alemão, ou seja, os elementos como lugar, objeto ou sujeito capacitado

\footnotetext{
${ }^{205}$ A esse respeito ver: OLIVEIRA, F. O surgimento do antivalor: capital, força de trabalho e fundo público. In:OLIVEIRA, Op. Cit, p. 46, e YAZBECK, M. C. A política social brasileira nos anos 90: a refilantropização da questão Social. In: Cadernos Abong. São Paulo: Abong, 1995.

${ }^{206}$ RANCIÈRE, Op. Cit, p.376-7.
} 
a falar não estejam constituídos, então o diálogo deixa de existir. Não há possibilidade de acontecer o acordo, posto que não há consenso.

$O$ que se destaca na teoria politica de Habermas é a importância que dá à existência da esfera pública, espaço em que esse diálogo deve ocorrer, e que, portanto, é imprescindivel para a democracia. Como apontou a cientista politica Nancy Fraser:

The idea of 'the public sphere' in Habermas's sense is a conceptual resource that can help overcome such problems. It designates a theater in modern societies in which political participation is enacted through the medium of talk. It is the space in which citizens deliberate about their commum affairs, hence, an institutionalized arena of discursive interaction. [...] Thus, this concept of the public sphere permits us keep in view the distinctions between state apparatuses, economic markets, and democratic associations, distinctions that are essential to democratic theory. ${ }^{207}$

A racionalidade política para Rancière, ao contrário de Habermas, não está identificada com consenso e muito menos o consenso é identificado com o princípio da democracia. Para Jacques Rancière o motor da prática democrática é o conflito. A capacidade de discordar e mostrar novos caminhos. É, portanto, o dissenso, o resíduo que fica de uma discussão e que volta a tona. O que não consegue ser negociado.

A escolha desse termo [dissenso] não busca simplesmente valorizar a diferença e o conflito sob suas diversas formas: antagonismo social, conflito de opiniões ou multiplicidade das culturas. O dissenso não é a diferença dos sentimentos ou das maneiras de sentir que a política deveria respeitar. É a divisão do núcleo mesmo do mundo sensivel que institui a política e sua racionalidade própria. Minha hipótese é, portanto, a seguinte: a racionalidade da política é a de um mundo comum instituído, tornado comum, pela própria divisão. ${ }^{208}$

O governo e a mídia tendem a rotular e não ouvir os "baderneiros" ou "vândalos". Não ouvindo se destrói qualquer possibilidade de entendimento e assim se desmancha a politica posto

\footnotetext{
${ }^{207}$ FRASER, N. Rethinking the public sphere: a contribution to the critique of actually existing democracy. In: Social Text, $n^{0}$ 25/26. Durham, NC: Duke University Press, 1990, p 57.

${ }^{208}$ RANCIÈRE, Jacques. Op. cit. p.368.
} 
que não existe o diálogo. Aquiles mostra ter perfeita noção disso ao afirmar:

Às vezes, a gente tem muitos presos políticos. Que vai preso pela versão da justiça... não tem a versão do trabalhador. "O Movimento Sem Terra é formador de quadrilha... Está preso!" Aí bota isso na mídia, e muita gente pensa que é verdade. Pensa que assistir a mídia é saber da verdade. Mas não é porque queremos a reforma agrária que somos formador de quadrilha.

De forma geral a população comum não partilha dessa opinião, e várias vezes durante a marcha pude presenciar o que Wanderléia contou em sua entrevista, ao falar de um despejo quando foram para a beira da estrada:

Daí os carros passava, chamava "cambada de vagabundo, vão trabalhar". Eu respondia: "Dá o trabalho, que é isso que a gente quer!" Outro aplaudia, falando que a gente tinha que fazer isso mesmo!

Evidentemente, pode-se pensar que há diferenças de pontos de vista, mas essa é também uma disputa que deve ser travada, pois na maioria das vezes o que ocorre é que a polifonia é silenciada, ouve-se apenas um único som e o aceita-se como verdadeiro.

Assim o dissenso antes de ser oposição entre um governo e as pessoas que o contestam, é um conflito sobre a própria configuração do sensivel. Os manifestantes põem na rua um espetáculo e um assunto que não têm aí seu lugar. E aos curiosos que vêem esse espetáculo, a polícia diz: 'Vamos circular, não há nada para ver'. O dissenso tem assim por objeto o que chamo o recorte do sensivel, a distribuição dos espaços privados e públicos, dos assuntos que nele se trata ou não, e dos atores que têm ou não motivos de estar aí para deles se ocupar. Antes de ser um conflito de classes ou de partidos, a política é um conflito sobre a configuração do mundo sensivel na qual podem aparecer atores e objetos desses conflitos. ${ }^{209}$

É isso que ocorre nas manifestações organizadas pelo MST. Evidencia-se o conflito entre mundos tão distintos, de incluídos e estabelecidos versus excluídos e outsiders. Nesses momentos, surgem

\footnotetext{
${ }^{209}$ Idem, p. 373.
} 
"atores" como os que aparecem nesse trabalho. Nessas manifestações emergem suas preocupações e demandas.

A indignação [das elites] torna-se ainda maior pelo fato de que o MST faz política. Seus dirigentes e militantes são afiliados a partidos políticos, candidatam-se a cargos eletivos, apóiam publicamente candidatos a cargos majoritários. Como a elite considera a política seu "território de caça privativo", a reação é violenta. Mas isso ainda não é tudo: o MST organiza e participa de todo e qualquer protesto social. Não há manifestação feminista, ato público pró-indígena, comício contra o pagamento da dívida externa, sem a presença das bandeiras do movimento e sem a palavra inflamada de seus dirigentes. O tom dessas manifestações é sempre o mesmo: a necessidade de completar a construção da Nação brasileira. ${ }^{210}$

Não se pretende aqui fazer uma teoria inovadora sobre a importância da atuação de movimentos sociais para o surgimento de um espaço de discussão, debate, reflexão, educação e formação. Propõese entender algumas das leituras de pensadores da realidade específica do Movimento dos Trabalhadores Rurais Sem Terra.

À luz dessas reflexões pode-se pensar que o resultado da ação do MST não é apenas a conquista da terra, mas buscar ser visivel e audivel, aparecendo assim no espaço público, e tornando seus membros cidadãos mais atuantes.

O impacto do movimento social é trazer seus motivos a público, não apenas suas estratégias e políticas, mas evidenciar a montagem de um referencial público de dignidade, de eqüidade. Para Habermas tem-se que lutar por qualquer forma de sociabilidade, e é em decorrência disso que se dá importância ao movimento social, à medida que é o catalisador dessa prática.

Nesse sentido, a luta do Movimento dos Sem Terra é também por ser visto e ouvido. Constantemente seus membros buscam ser visiveis. A partir da negativa do governo em atender as reivindicações, os trabalhadores passam a "usar formas de pressão política mais fortes

\footnotetext{
${ }^{210}$ SAMPAIO, P. A. A mística. Disponível em: http://www.landless-voices.org/vieira/archive05.phtml? rd=MSTICAOF657\&ng=p\&sc=3\&th=42\&se=0, acessado em 18/04/07.
} 
tais como ocupações de terra, acampamentos, ocupação de prédios públicos, bloqueio de rodovias, ocupações de praças públicas etc". 211 Com isso vê-se emergir neste quadro social diversas estratégias de luta com diferentes objetivos. Há a ocupação de terras improdutivas ou devolutas, com o claro intuito realização da reforma agrária, mas também a ocupação de locais públicos chamando a atenção da mídia para que suas vozes sejam ouvidas e repercutam em prol da aceleração de algum projeto de assentamento específico, ou mesmo para reivindicar maiores financiamentos ou prazos aos bancos. Enfim, ações práticas com metas bastante concretas.

O que se passa é uma contestação das propriedades e do uso de um lugar: uma contestação daquilo que é uma rua. Do ponto de vista da política, uma rua é um espaço de circulação. A manifestação, por sua vez, a transforma em espaço público, em espaço em que se tratam os assuntos da comunidade. Do ponto de vista do que enviam as forças da ordem, o espaço onde se tratam os assuntos da comunidade situa-se alhures: nos prédios públicos previstos para esse uso, com as pessoas destinadas a essa função. ${ }^{212}$

A inserção do indivíduo em um movimento social dá a sua existência um sentido coletivo, um projeto. A vida em grupo, como acontece nas cooperativas, faz com que a esfera do estritamente privado perca significado e sentido. Os que estão ali presentes não mais estão isolados, agem solidariamente na coletividade. O caminho de casa para o trabalho, (a plantação, o setor de máquinas, o setor de construção e o administrativo) é permeado por conversas, fazendo com que o debate de questões politicas e sociais passe a ser parte do cotidiano.

À medida que membros do MST definem o objetivo de sua luta, conversam, mobilizam-se, decidem conjuntamente, ocorre a formação de pessoas capacitadas a ocupar e ampliar o espaço público $O$ ativismo nem sempre resulta em conquistas concretas, mas assegura um lugar para o fazer democrático.

As discussões travadas nos acampamentos e assentamentos pelas pessoas que participam dos processos de produção é elemento

\footnotetext{
${ }^{211}$ STÉDILE, J. P. e Frei Sérgio. A luta pela terra no Brasil. São Paulo: Scrita, 1993, p. 51.

${ }^{212}$ RANCIÈRE, Op. Cit., p.373.
} 
básico da democracia. Nessas discussões são expostos pontos de vista diferentes e os membros daquela comunidade devem, em meio ao dissenso, chegar a um denominador comum. Aprende-se muito nessa vivência sobre negociações e sobre o fazer político. Algo impensável na vida dessas pessoas antes da entrada no movimento social.

Dito isso, retoma-se a discussão proposta por Castoriadis e afirmar que essas discussões, que no caso desse trabalho acontecem no espaço dos acampamentos e assentamentos, retomam o "germem"213 grego, democrático, para discutir a relação política. Essas pessoas repensam, portanto, a concepção de Estado e Sociedade em termos contemporâneos. O contrato social passa a ser pensado por meio de grandes coletivos de cidadãos.

Castoriadis pressupõe um indivíduo pensante, que media o mundo em conflito no qual vive e que direciona suas escolhas por meio de suas experiências. Pensa o cidadão democrático como sendo o indivíduo que tenta ultrapassar a esfera de suas preocupações mais particulares e passa a se interessar ativamente pelo que acontece na sociedade em geral e afirma que "são esses mesmos homens e mulheres que devem tornar-se sujeitos ativos da política explícita"214.

Sendo assim, o MST amplia e recria o espaço público ao falar e fazer ser ouvido. E isso só é possível, como grupo ou coletivo, por meio da "cidadanização" de seus membros, sistematizando suas aspirações, consolidando uma identidade central ou oficial. Com a organização de seu discurso passa a ter a possibilidade de poder dialogar, pois os ruídos animalescos transformam-se em fala humana articulada e, portanto, política.

"Esquecemos que essa conjunção banal de palavras foi o confronto violento não apenas de interesses, mas de mundos contraditórios."215 Parafraseando Rancière, esquece-se a violência simbólica que o simples fato de colocar a terra como objeto de discussão

\footnotetext{
213 “... a Grécia é para nós um gérmem: nem um ‘modelo’, nem um espécime entre outros, mas um gérmem.” CASTORIADIS, C. As encruzilhadas do labirinto II. Os domínios do homem. s/d, p. 271.

${ }^{214}$ CASTORIADIS, C. Os intelectuais e a história. In: As encruzilhadas do labirinto 13. O mundo fragmentado. Rio de Janeiro: Paz e Terra, 1992, p.113.

${ }^{215}$ RANCIÈRE, Jacques. Op. Cit., p.375.
} 
pública pôde representar em um país com uma estrutura fundiária como a brasileira.

Os sem-terra enfrentaram esse debate e com isso alargaram o espaço público de sua atuação, pois ela passa a ser ao mesmo tempo ação "perturbadora” e, portanto segundo Rancière, política.

Proponho reservar a palavra politica ao conjunto das atividades que vêm perturbar a ordem da polícia pela inscrição de uma pressuposição que lhe é inteiramente heterogênea.

Essa desordem, ou sobre outro ponto de vista, essa nova ordem organiza o viver dos sem-terra cotidianamente. Quando acampados ou em marcha estão "fora da ordem" previamente estabelecida, falando sobre assuntos que não devia ser tratados, pela organização política tradicional da sociedade brasileira. Falam de distribuição de terra, de igualdade jurídica, de respeito à diversidade, de justiça para os pobres. Da exclusão se levantam e se incluem, sem pedir licença, as discussões políticas nacionais, lembrando a muitos que um princípio da democracia e da politica é a igualdade, mas uma igualdade que deve ser entendida de forma diferente.

A política, em última instância, repousa sobre um único princípio, a igualdade. Só que esse princípio só tem efeito por um desvio ou uma torção específica: o dissenso, ou seja, a ruptura nas formas sensiveis da comunidade. Ele tem efeito ao interromper uma lógica da dominação suposta natural, vivida como natural. Esse efeito é a instituição de uma divisão ou de uma distorção inicial. Essa distorção é que é testemunhada pelas palavras aparentemente muito simples: demos e democracia. ${ }^{216}$

Os sem-terra, assim, passam a também realizar novos modos de fazer politica: participando de governos ou manifestando-se. Gostaria de dizer que ao colocar o "pé na estrada" retomam formas de manifestações e resistências tradicionais dos camponeses. Contudo, como dominam certos protocolos e não estão distantes do mundo político institucional reivindicam seus direitos e fazer pressão efetiva

\footnotetext{
${ }^{216}$ Idem, p.370.
} 
sobre o governo, sendo ouvidos para que políticas públicas sejam realizadas.

Pode-se perceber uma mudança de outras marchas para essa ao se levar em conta o que representa um governante "vindo de baixo", como eles, ocupar o cargo mais alto do executivo federal do país. Os politicos, em um governo popular, no mínimo, se apresentam mais próximos dessas pessoas e de fato, mesmo não dando conta das mudanças prometidas, não se fecham ao diálogo. Mas esse encantamento não cega para problemas e contradições dessas gestões.

Os membros do MST têm uma visão perspectiva e por isso apontam suas frustrações atuais geradas pela contradição entre a prática politica e a trajetória vivida anteriormente por politicos como o presidente Lula. Sobre isso, destaca-se um trecho da entrevista de seu Luís:

Acho bom marchar para melhorar o país. A gente está sempre fazendo uma força. Vamos ver se dessa vez melhora, porque o Lula prometia muita coisa e para nós ele não está fazendo. Quando o Lula perdeu, uma vez, ele foi no acampamento e falou muita coisa da reforma agrária. Falou que precisava fazer a reforma agrária e que não era só dar terra, era dar um jeito de tocar a terra. Falou que o agricultor precisava de remédio, estrutura, essas coisas. Ele falou isso. Queria falar com ele, se alembra. Eu lembro do que ele falou. Mas ele, não sei se lembra.

Além da crítica frente às promessas históricas, tais pessoas têm clara a noção do abismo que separa os mundos dos quais cada um faz parte. E em narrativas como a de Wanderléia essa diferença, e a privação imposta por ela é reforço para uma identidade de resistência.

Queria que o presidente visse isso e passasse pelo menos uma semana debaixo da lona preta para ele ver que durante o dia se botar um bolo você assa e a noite, fica uma friagem... Quando chove é uma tristeza, a gente dorme dentro d'água. Muitas vezes, eu e meus filhos dormiam, assim em pé... Época de natal, de festa, ano novo passava com as crianças no braço e a chuva caindo dentro da barraca. Muitas vezes passei isso. Mas não fui só eu, as outras famílias também. 
Nesses dias a gente não tinha para onde ir. Passamos muito sufoco, com fome... A barriga roendo e nós lá. Por quê? Acreditando que um dia o ser humano pudesse ter alguma coisa na vida, já passamos muita necessidade.

Ao ler as narrativas pode-se ter contato com as várias reflexões feitas pelos colaboradores dessa pesquisa sobre os deveres do poder público. Nesses momentos transparece a crítica, mas também uma esperança em Lula, o presidente que, como eles, era pobre. De forma geral, esse governo não é visto como inimigo, mas como ineficiente e não cumpridor das promessas feitas. Com isso mantêm-se uma expectativa de que essa situação possa mudar.

Assim, pessoas marcadas pela exclusão, passam a ter uma esperança de inclusão, de tornarem-se cidadãs e construírem uma democracia mais participativa e não necessariamente consensual. A “inclusão" proporcionada pelo grupo, é da ordem do sentir-se parte, não necessariamente do estar materialmente melhor. Contudo, isso aparece nas histórias de vida com uma força que leva a pensar que mesmo em semente a possibilidade de inclusão guarda uma potência criativa, que ao mesmo tempo é contestatória, quando se pensa na estrutura política e social brasileira, e acalentadora, ao possibilitar que tais pessoas façam parte de uma comunidade, na qual não se sentem excluídas. 


\section{Processos de identificacão:}

mediação no Movimento

É dificil explicar o que é ser sem terra. Como eu vou falar? Acho que bastante gente é sem-terra e não sabe. Daniel

A identidade sem terra é muito forte porque não é pelo fato de plantar, de ser uma camponesa, de trabalhar na terra, mas sim pelo fato de você levar essa identidade com você. Essa identidade é muito forte, ela vai além disso. A gente sente essa identidade quando leva os sentidos da organização, como o compromisso. Um dos princípios é a organicidade. Quando você vê a organização no todo, se sente como sem terra. Essa coisa da organização interna da nucleação, da estruturação... Ana Paula

Interpretar é sempre um risco. As análises são transitórias, incompletas e contingenciais, pois não é possível falar com todos os sem-terra e ainda que fosse, não se conseguiria acompanhar as mudanças de todo um grupo. Com isso, o exercício de interpretar é sempre mostrar uma forma de ver o assunto.

Além disso, a interpretação de uma história de vida ou um de evento é resultado da relação estabelecida pelo pesquisador com o assunto pesquisado. Por isso, ela pode ser diferente da interpretação de outros pesquisadores ou mesmo daquela que os narradores fariam de sua própria história. Isso porque cada um interpreta algo usando as ferramentas e referências presentes em seu próprio mundo. Nesse sentido: "if you say to a child 'the day is almost gone' he will take you at your world and will find wonder in it. But if you say this to a man whom the world disappointed, he will be bound to doubt it"217.

Sendo assim, acredita-se que cada pessoa é capaz de fazer sua própria interpretação e certamente a que os colaboradores dessa

\footnotetext{
${ }^{217}$ McCONKEY, J. The anatomy of memory: an anthology. New York: Oxford University Press, 1996, p.
} 238. 
pesquisa fariam seria diferente da que ora se apresenta. Escrever, entretanto, é ocupar uma posição de autoridade e independência, que deve ser exercida com responsabilidade.

As análises, interpretações ou leituras sobre a identidade desses narradores não correspondem exatamente àquilo cada um deles pensa ser sem-terra, mas leva em conta esse conjunto de referências que foram coletadas ao longo da pesquisa. É o que se viu a partir das tramas biográficas e de uma vivência de campo. Elas não são as únicas versões possíveis, nem tão pouco são a História do Brasil ou da luta de trabalhadores. São partes de uma história brasileira de trabalhadores, que compõe um panorama muito mais complexo.

Nesse trabalho, procura-se analisar como identidades relacionadas aos sem-terra ${ }^{218}$ se formam na fala das pessoas que fazem parte do MST. Nesse sentido, o processo de narrar as histórias de vida e as relações desta com o Movimento são a base para se entender a construção da identidade, ao mesmo tempo, o narrar é ele também construção.

A narrativa é, pois, base e pode dar significado à formação da identidade. Por sua vez, a memória, de algo vivido ou não, é essencial para a constituição da narrativa. A memória coletiva de um passado de lutas e a vontade de conquistar a terra, recontadas em cada narrativa individual foi o solo de onde cresceu o Movimento e brotaram identidades. Neste processo pode-se entender a relação entre memória coletiva e individual, trabalhada por Halbwachs. Hoje, entretanto, há uma maior abrangência desse processo. O MST passa a atuar nos campos da educação, da cultura, da produção, pensando um jeito de

\footnotetext{
${ }^{218} \mathrm{O}$ termo sem-terra será utilizado para denominar o grupo de pessoas que, fazendo ou não parte do Movimento dos Trabalhadores Rurais Sem Terra, luta para conquistar seu pedaço de chão. Em algumas passagens desse trabalho é usado "Sem Terra" para denominar o membro do MST e marcar a constituição de uma identidade mais oficial, ligada a esse pertencimento, de acordo com a perspectiva do próprio Movimento.
} 
viver do campo em equilíbrio com o meio ambiente ${ }^{219}$. Suas preocupações no presente vão "além da terra"220.

Esse apoio é importante e fica bem claro dentro dos objetivos do Movimento Sem Terra. Lutar pela terra. Entender que os nossos problemas não estão resolvidos mesmo depois ter a terra, porque estão dentro de um conjunto bem maior. Nós estamos lutando com cinco, seis alqueires de terra, dependendo da região, contra um latifúndio. Nós não vamos conseguir competir com ele. É desigual. Além disso, é importante lutar pela reforma agrária para que te possibilite ter uma vida melhor, na terra que conquistou, e também para que as outras famílias sem terra tenham acesso a essa terra. Também acho que é a questão da sociedade diferente. A nova sociedade que queremos construir... Vamos conseguir se lutar pela reforma agrária e fazer a luta maior para transformar a sociedade que está aí!

Neste trecho fica claro o objetivo principal do MST, todavia pode-se notar que a partir da entrada no Movimento novas preocupações começam a fazer parte do cotidiano dessas pessoas que entendem seus problemas de forma mais complexa e que por isso passam a sonhar com uma sociedade diferente. E Adelir vai além:

A gente costuma dizer que se hoje tem a terra, o local para plantar, a vaca para tirar o leite, a casa para morar... Tem tudo isso porque a organização fez com que tivesse. Lógico que cada um de nós fez a sua parte, mas quem possibilitou foi ela. Não conseguimos imaginar como seria fora dela. Com certeza, as dificuldades seriam muito maiores.

Neste fragmento, aparece a gratidão ao MST pelas conquistas, mas o reconhecimento de que ela é resultado da ação conjunta, entre sujeito e movimento social. Ou melhor, de sujeito organizado em movimento social. Adelir compreende que o movimento é a junção das várias pessoas e que essa união organizada faz a diferença para a vida de muitas famílias e é essa sua forma de mostrar a gratidão reconhecendo o próprio esforço.

\footnotetext{
${ }^{219}$ Idéia trabalhada no capítulo “A opção verde” do livro BRANDFORD, S. e ROCHA, J. Rompendo a cerca: a história do MST. São Paulo: Casa Amarela, 2004, pp. 285-323.

${ }^{220}$ Preocupação marcada em publicações como: MENESES NETO, A. J. de. Além da terra: cooperativismo e trabalho na educação do MST. Rio de Janeiro: Quartet, 2003.
} 
Adelir explica que fazer parte da "luta" é algo difícil, mas sem ela seria pior. Esse é um discurso de uma liderança, mas é preciso notar que essa liderança se formou em plena luta. O conjunto das entrevistas mostra a consciência que os narradores têm de que ao pobre resta a opção da esperança de uma mudança no futuro, mas que esse futuro apenas se concretizará por meio da ação organizada.

A partir destas afirmações de Adelir pode-se constatar que as identidades relacionadas ao Movimento Sem Terra foram se organizando, aos poucos, e um dos principais elementos que contribuíram nesse processo é a conquista da terra. A existência dos assentamentos e a dinâmica da vida dentro deles é uma alavanca para a questão identitária. Assim os sem-terra vão forjando suas identidades em um território, na medida em que sua territorialização acontece.

Cabe notar a distinção feita pelas lideranças do MST do uso de sem-terra e Sem Terra. A primeira expressão, grafada com iniciais minúsculas e com hífen, ora no singular, ora no plural é a designação de um grupo social, que projeta uma identidade comum, não necessariamente vinculada a nenhum movimento social específico. Nessa visão, são sem-terra os membros de vários movimentos camponeses, a saber: MAB - Movimento de Atingidos por Barragens, MMC - Movimento de Mulheres Camponesas ou MSTR - Movimento Sindical dos Trabalhadores e Trabalhadoras Rurais. Por fim Sem Terra, com iniciais maiúsculas, sempre no singular refere-se à formação da identidade do grupo que é estudado por essa pesquisa, ou seja, membros do Movimento dos Trabalhadores Rurais Sem Terra.

O MST nunca utilizou em seu nome nem o hífen, nem o s, o que historicamente acabou produzindo um nome próprio, Sem Terra, que é também sinal de uma identidade construída com autonomia. O uso social do nome já alterou a norma referente à flexão de número, sendo hoje já consagrada a expressão são os sem-terra. Quanto ao hífen, fica como um distintivo da relação entre esta identidade coletiva de trabalhadores e trabalhadoras da terra e o Movimento que a transformou em nome próprio, e a projeta 
para além de si mesma. ${ }^{221}$

Uma outra explicação necessária é o uso da palavra Movimento, com maiúscula, para designar o MST. Essa palavra é usada também por conter idéias de mudança em continuidade, de ação, de transformação constante que evidentemente permeia um processo contínuo de identificação.

A escolha do tema de estudo "identidade" dentro de um movimento social foi impulsionada pelo fato de haver debates e disputas em torno dessa questão, que acabaram por alargar o uso do conceito dentro do MST. Assim são apresentados contrapontos à própria identidade "Sem Terra", denominada por lideranças e assumida pelo Movimento frente às várias identidades dos sem-terra.

Essa disputa se dá tanto no campo acadêmico, posto que algumas lideranças ocupam lugares nesses meios, quanto nas reuniões de coletivos, nos assentamentos e acampamentos do MST. Tais disputas se dão em meio à continuidade da luta pela reforma agrária, que ainda se caracteriza como um dos amálgamas para a luta desses sujeitos por seus direitos, embora seja importante marcar que a luta pela terra não é mais a única bandeira do Movimento dos Sem Terra. Daniel deixa claro o entendimento dessa questão ao afirmar:

No começo da luta, a gente entra no acampamento só por um lote de terra. Mas percebe que tem uma luta maior, que é educação, saúde e até mesmo a construção da nova sociedade que a gente quer. Eu acho que é mais isso. Depois que a gente vai aprendendo... O acampamento é uma escola. A gente vê as coisas, e vai despertando o senso crítico. Vê o mundo como está.

Mais uma vez a entrada no MST é destacada como momento de tomada de consciência, não apenas de uma situação anterior de exclusão, mas da percepção de que para se viver ${ }^{222}$ é preciso ter acesso a um conjunto de direitos que lhes foi negado, como educação e saúde.

\footnotetext{
${ }^{221}$ CALDART, R. S. Pedagogia do Movimento Sem Terra: escola é mais do que escola. Petrópolis, RJ: Vozes, 2000, p. 17.

${ }^{222}$ Bios e não zoe - segundo diferenciação mostrada por AGAMBEM, op cit, 2002, p. 9.
} 
Freqüentando a "escola do acampamento" essas pessoas passam a dimensionar suas atuações, buscando uma mudança estrutural de suas vidas que tem como meta a conquista da terra, mas não se basta nisso.

Autores que se dedicaram a estudar o Movimento percebem essa questão da seguinte forma:

Neste mundo de monopólios e desemprego, de concentração e exclusão, a luta do MST é a luta de cidadãos, de trabalhadores, em busca do direito ao trabalho, à saúde, à escola, à cultura, ao lazer, etc. Enfim é uma luta pelos bens e direitos de cidadania. Neste sentido, a terra é, não o fim, mas o meio, para viabilizar esta inserção no mundo da cidadania. A luta do MST transcende, assim, a luta pela terra. ${ }^{223}$

Durante os últimos cinco anos, enquanto foram desenvolvidas atividades de pesquisa e militância, participei de muitas reuniões do Setor de Educação, e em uma delas deparei-me com uma disputa interna, em um grupo que até então me parecia coeso. Era um momento de comemoração, pois dois Setores do Movimento assumiam uma parceria: Educação e Cultura trabalhariam juntos em alguns projetos. Estávamos reunidos em um alojamento em Cajamar - SP, para que pudéssemos nos dedicar inteiramente às atividades do encontro. Tínhamos horários para as refeições, para nos reunirmos em assembléia ou em grupos e para estudarmos individualmente. Com raras exceções, esses horários eram rigorosamente cumpridos pelas mais de cem pessoas convidadas.

Entretanto, foi fora desses horários estabelecidos que aconteceu um confronto entre duas concepções de ser/agir dos membros do MST. Um dia, à noite, em nosso horário livre, membros dos dois setores estavam numa varanda cantando ao som de um violão um repertório bastante nordestino, como a maioria dos presentes. Animados, não vimos o tempo passar. Foi quando uma liderança sulista do Setor de Educação veio pedir silêncio, e notificar que deveriamos dormir, para estar dispostos ao trabalho no outro dia. Evidentemente,

${ }^{223}$ MENESES NETO, A. J. de. Op. Cit., p. 13. 
mesmo com alguma razão, aquela fala foi um banho de água fria nos cantadores presentes. Duas ou três músicas mais foram tocadas e todos foram dormir, alguns bastante constrangidos. Talvez inclusive por questão de honra, no dia seguinte, os "cantadores" estavam bem cedo na fila do café da manhã, provando que a "indisciplina" do dia anterior não afetaria os trabalhos a fazer.

Naquela noite, havia presenciado um embate entre duas visões, uma, que tem a festa e o compartilhar como forma de agremiação, e outra, que tem a ordem e a disciplina como forma de organização e mobilização. Pude observar essa disputa, em maior ou menor grau, ocorrendo em várias outras ocasiões. ${ }^{224}$ Embates como esses são constantes motores para mudanças do modo como o MST age e se pensa.

Dilemas assim marcam as relações estabelecidas entre militantes do Sul e Nordeste, assim como entre homens e mulheres e entre as várias gerações. Esses grupos e seus diversos componentes têm idéias bastante particulares a respeito de o que é ser "Sem Terra". Frente a essa pluralidade comecei a questionar a própria validade da formação dessas identidades.

De forma geral, nas mobilizações e nas festas pessoas de diversas procedências e pontos de vista se encontravam. Ao mesmo tempo em que esses eram momentos de sociabilidade, também eram situações de negociação e troca de experiência. Dançava-se vaneirão ou forró, independentemente da origem da pessoa. Dessa experiência de vida conjunta e trocas constantes pode-se afirmar que não há um padrão para ser sem-terra, e nem mesmo que essa identidade se consolidou, ela está em constante diálogo e mutação.

O objetivo desse trabalho foi, portanto, registrar e analisar as narrativas dos sem-terra, para entender como e com que importância o

\footnotetext{
${ }^{224}$ Vários autores utilizam o artifício de contar algo que aconteceu na vivência de campo, para a partir disso, analisar um determinado tema. A esse respeito ver : FONSECA, C e BRITES, J. (Orgs)

Etnografias da participação. Santa Cruz do Sul: EDUNISC, 2006. Neste livro destaca-se o trabalho de CHAVES, C. A., pp. 36-58.
} 
MST aparece nelas e se ele é um elemento de (re)estruturação de identidades.

A partir desse objetivo central, buscou-se nessa pesquisa entender porque uma pessoa se torna membro do Movimento Sem Terra. A maioria das pessoas com que falei aponta dois argumentos principais que poderiam ser caracterizados como objetivos e subjetivos. Chamo de razões objetivas, embora nem sempre possam ser percebidas objetivamente, a questão da violência, do desemprego, da crise social, da fragilidade da economia brasileira, do descaso político, dentre outros, que já foram trabalhados no capítulo anterior. As razões subjetivas podem ser relacionadas à decepção, às crises pessoais e familiares, à solidão e a vontade de acabar com ela e sentir-se parte de algo.

Posto isso, cabe ressaltar a importância da subjetividade que, ao ser explorada, ajudou a mostrar outras verdades, interpretações diferenciadas, que superaram a idéia de um passado único, "real" e "científico" até então construído.

Com isso não quero apontar a objetividade como algo negativo ou positivo, mas como algo que deve ser entendido em conjunto com outros conceitos, como subjetividade, para que ganhe significado. Caso contrário se torna algo inalcançável. Portanto o que pretendo é me afastar das pretensões de objetividade que muitas vezes marcam a utilização das tecnologias, dos registros e da pesquisa em história oral, mesmo no campo teórico em que a questão da interpretação se firmou. ${ }^{225} \mathrm{Um}$ desvio tende a confundir a representação do real com o real mesmo, ou a representação do passado com o que de fato ocorreu, e que porque passado, é impossivel de ser revivido.

Propõe-se então que se faça a transição da valorização da objetividade "pura" e se assuma a subjetividade como algo importante e de grande valor para entender os movimentos de uma sociedade. Dessa forma, as narrativas aqui colocadas são exemplos de objetivações da

\footnotetext{
${ }^{225}$ No campo da história oral podemos citar alguns trabalhos como os de Portelli, no entanto muitos outros são os teóricos a desenvolver tais argumentos nas diversas áreas das ciências humanas, apenas a título de exemplificação podemos citar as obras de autores como: Foucault, White e Gertz.
} 
subjetividade. O narrar é um processo de objetivação de subjetividades, pois é momento em que memórias são acessadas, selecionadas e traduzidas em palavras a serem gravadas e transcritas. Processo que o colaborador sabe que acontecerá, pois toda entrevista é precedida de uma introdução em que se fala, em linhas gerais, a intenção do projeto.

Tem-se em mente que cada uma das histórias narradas é uma construção que só pode ser entendida na ativação de suas subjetividades. Para isso é importante lembrar o que Foucault definiu como práticas subjetivadoras, objetivadoras e discursivas. Não cabe aqui buscar definir fronteiras entre os tradicionais pareamentos fato/ficção, parcialidade/imparcialidade, verdade/mentira, objetividade/subjetividade. Mais que opostos, essa pesquisa quer pensá-los como complementares.

Faz-se necessário, no momento, levar em conta que os historiadores e etnógrafos estão no ramo da ficção tanto quanto romancistas e poetas; em outras palavras, que também eles são produtores de "artefatos literários" de acordo com regras de gênero e estilo (quer estejam conscientes dessas regras, quer não) (White, 1973, 1976; Brow, 1977, Clifford \& Marcus, 1986). Recentes estudos sobre a "poética da etnografia" descreveram os trabalhos de sociólogos e antropólogos como a construção textual" da realidade, comparando-a a obra de romancistas. ${ }^{226}$

As ciências são formas de objetivação, segundo Boaventura Sousa Santos:

As leis da ciência moderna são um tipo de causa formal que privilegia o como funciona das coisas em detrimento de qual o agente ou qual o fim das coisas. É por essa via que o conhecimento científico rompe com o conhecimento do senso comum. É que, enquanto no senso comum, e portanto, no conhecimento prático em que ele se traduz, a causa e a intenção convivem sem problemas, na ciência a determinação da causa formal obtém-se com a expulsão da intenção. É este tipo de causa formal que permite prever e portanto, intervir no real e que, em última instância, permite à ciência moderna responder à pergunta sobre os fundamentos do seu rigor e da sua verdade com o elenco dos seus êxitos na manipulação e na transformação do real.

${ }^{226}$ BURKE, Op. Cit., 2002, p.176 
Um conhecimento baseado na formulação de leis tem como pressuposto metateórico a idéia de que o passado se repete no futuro. ${ }^{227}$

Práticas discursivas são o que constituem o sujeito (discurso escrito, oral, representações) - e essas permeiam as práticas objetivadoras e subjetivadoras. Subjetividade e objetividade são dois lados de uma mesma moeda, inseparáveis, que de certa forma se complementam, ao mesmo tempo que se auto-constituem, lembrando que sujeitos constroem e desconstroem suas estruturas. ${ }^{228}$

Discute-se a construção de uma abordagem específica a partir da pesquisa desenvolvida e da mediação feita junto ao grupo de trabalhadores sem terra. Fixando as narrativas, impulsionadas pela memória, desenvolve-se uma reflexão sobre as possibilidades de compartilhar representações, repensando o movimento de construção de sentidos na dinâmica das relações sociais.

Pretende-se organizar uma reflexão sobre a construção da auto-imagem, e da auto-imagem do grupo ao qual cada um desses narradores pertence. Uma reflexão sobre o trânsito estabelecido entre imaginário, memória e a vivência concreta do mundo a partir de alguns personagens e seu cotidiano. Tanto os colaboradores quanto o cotidiano por eles vivido foram abordados por meio da realização de gravações de suas tramas biográficas, que depois foram transpostas do código oral para o escrito. Nesta experiência a realização desses registros se transformou num espaço de elaboração de questões conceituais que alimentaram a pesquisa e que serão trabalhadas ao longo do texto. Assim, reflexões de cunho mais metodológico ou mais

\footnotetext{
${ }^{227}$ SANTOS, B. S. Um discurso sobre as ciências. São Paulo: Cortez editora, 2005, p. 30.

${ }^{228}$ O termo “desconstrução” provém da obra do filósofo francês Jacques Derrida, que intencionou destruir logocentrismo do sujeito universal. O conceito de desconstrução suscitou admiradores no mundo acadêmico, principalmente nos departamentos de Letras, ao mesmo tempo que provocou revolta e polêmica no mundo da filosofia canônica, visto como uma ameaça aos estudos clássicos. Sua aplicação levanta todo o problema de uma terminologia científica, secularmente dominante em nossa cultura ocidental. A “desconstrução” de um texto pressupõem a inexistência de uma leitura verdadeira, tornando qualquer leitura feita uma dentre as possíveis, nunca "a” correta. Para Derrida "A linguagem se cria e cria mundos”, assim os textos corrompem seus significados tradicionais e os conceitos arrastam consigo uma pluralidade de interpretações, criando novos contextos que permitem novas leituras, em um processo contínuo. DERRIDA, J. Gramatologia (1967). São Paulo: Perspectiva; Editora da USP, 1999.
} 
temático serão tratadas em conjunto, estabelecendo uma relação entre esses dois aspectos da pesquisa. Ou seja, entendo que os momentos de produção de documentação são privilegiados para a reflexão desde que pensados como o lugar do encontro, da intersubjetividade, criando intertextualidade. ${ }^{229}$

Os narradores parecem em suas entrevistas relatar uma história onde há um rompimento com um processo de desenraizamento e o restabelecimento e a criação de vínculos. O enraizamento é um dos conceitos desenvolvidos por Simone Weil, e comentado por Ecléa Bosi: "O ser humano tem uma raiz por sua participação real, ativa e natural na existência de uma coletividade que conserva vivos certos tesouros do passado e certos pressentimentos do futuro".230 Ou seja, não se pode entender o ser humano se não se prestar atenção à sua inserção em seu contexto social. O grupo representa um conjunto de oportunidades - embora não único - a partir das quais se concretizam as ações particulares. É uma base sobre a qual se desenvolvem as ações significativas da pessoa, efetuadas no espírito de pertencer e de participar.

Retomo assim a reflexão tecida por Giddens. Para o autor, o aspecto central para a constituição da vida social é entender o desempenho das práticas sociais. Não há como entender a vida dos Sem Terra sem entender suas práticas, assim vê-se no decorrer das entrevistas que os sem-terra sentem-se mais Sem Terra quando estão envolvidos em mobilizações, cursos, manifestações, e que elas são constantes no Movimento, pois ao tornarem-se rotineiras e efetivas têm a capacidade de alterar a vida dessas pessoas. Ser um coordenador de acampamento, um educador, um agente de saúde, militante ou

\footnotetext{
${ }^{229}$ Desta forma, transponho para este trabalho, traçando paralelos, uma reflexão tecida por David MacDougall sobre o a realização do documentário etnográfico como elemento fundamental no processo da pesquisa antropológica. A elaboração de um filme pressupõe um diálogo "intertextual” em que "sérios problemas teórico-metodológicos se apresentam, tais como: cinema de observação ou cinema de participação; presença afirmada do realizador-antropólogo ou ensaio de objetivação da observação; intervenção sobre o evento ou registro; descrição do discurso ou desenvolvimento com comentários; legendas ou cartões explicativos; tamanho de equipes de filmagem; construção ou reconstrução da realidade observada. MONTE-MÓR, P. Sobre antropologia e imagem. In: ABA, nº 31, Museu Nacional, Departamento de Antropologia, 1999, p.15.

${ }^{230}$ BOSI, E. Op. Cit., p. 75.
} 
dirigente, empodera esses sem-terra e transforma em cotidiano essa mudança e esse vínculo com o MST. A questão do empoderamento dessas pessoas, provocado pelo MST é muito importante, pois com isso elas se sentem melhores, percebem possibilidades de outros caminhos além de receber um suporte para o caminhar conjunto.

"Vendo tudo isso eu me assustei" afirmou Ana Paula, ao marcar o momento em que foi desafiada a realizar tarefas que achava que não ia dar conta. Mas deu. Vê-se assim a construção de uma autoestima. Nesse sentido, ao se dividir as tarefas, há um empoderamento desses sujeitos, que vão assumindo responsabilidades frente ao grupo.

O processo de reconhecimento de uma responsabilidade e do empoderamento por parte do que chamam de "companheiros" é fundamental. Esse processo estende-se, no caminho percorrido por Elizandra, desde a elaboração de atas de reuniões até o efetivar-se membro do setor de educação. Ela resistiu a assumir a posição de educadora no assentamento, mas acaba cedendo e se sentindo capaz de realizar o trabalho para o qual foi designada, por ter auxílio de outros.

A idéia de representar o Movimento é relacionada à responsabilidade nas entrevistas de Ana Paula e Adelir. Quando se está em um lugar público quem está falando não é uma pessoa comum e sim um Sem Terra. Isso marca a diferença entre os sem terra e as outras pessoas.

Essa responsabilidade fica evidenciada no discurso de militantes quando estão negociando junto ao governo financiamentos ou parcerias em programas, em viagens que fazem para firmar acordos em outros países e mesmo nos marchantes, quando se dizem "Sem Terra", ou falam que não existiam antes de entrarem para o Movimento. Nesses eventos, esses sujeitos são o MST. Suas ações, mesmo que individuais, representam o Movimento. E eles têm clareza disso, por isso têm tanto cuidado com o que dizem e como se apresentam. Manifesta-se uma identidade do Movimento, “central”, que permite que sejam vistos como membros de um coletivo uniforme, coeso e, portanto, forte. 
O desempenho de ações, em companhia de outros, em determinados cenários, é condição necessária à reprodução de práticas sociais. Por sua vez, este desempenho reforça a consciência dos participantes quanto à constituição de suas circunstâncias sociais.

A força e a permeabilidade das fronteiras sistêmicas dependem de como se produzem as articulações na práxis social. A estruturação (isto é, reprodução ou alteração) de relações sistêmicas, através do tempo e do espaço pode ocorrer exclusivamente através de conseqüências nãointencionais, da práxis, ou implicar a administração intencional através de tempo e espaço. ${ }^{231}$

Adelir conta um pouco das contradições do "conforto" dessa experiência de viver o coletivo:

A vida no acampamento é sofrida, mas ao mesmo tempo não é sofrida... É o exemplo aqui da marcha. Por mais que monte o barraco, ponha o colchão no capim, enfrente um sereno... ao mesmo tempo que tem esse sofrimento, é um momento divertido! É um momento que tu olha para o companheiro e vê que ele está mais molhado que você! Tu olha para o companheiro e vê que o torrão que ficou embaixo dele, o carocinho embaixo do colchão é maiorzinho do que o teu. $\mathrm{E}$ faz a caminhada. Se está doendo o pé, não é só teu.

Esse argumento, mais ligado ao companheirismo encontrado no movimento, é contraponto à solidão experienciada anteriormente. Muitos relacionam sua entrada no Movimento ao "ganhar força", "sentir-se parte" e, portanto, tornar-se maior do que apenas um indivíduo.

Em momentos de mobilização os narradores percebem mais profundamente seu pertencimento. Donde se conclui que as mobilizações são momentos importantes na construção de uma identidade Sem Terra. O que também pode ser percebido no trecho em que Wanderléia diz:

A coisa que mais gosto de fazer, que mais me sinto bem é quando a gente reivindica os direitos. Antes de ir para o Movimento eu tinha medo de por exemplo, entrar numa fila e pedir alguma coisa. Eu queria brigar pelas coisas, mas ficava

\footnotetext{
${ }^{231}$ IRA, J. C. Verbete: Estruturação. In: OUTHWAITE, W. e BOTTOMORE, T. (orgs.). Dicionário do pensamento social do século XX. Rio de Janeiro: Jorge Zahar, 1996, p. 274-5.
} 
com medo. Me sentia uma formiguinha!... Me sentia assim pequenininha! Um nada... Agora não, eu sei dos meus direitos, chego num lugar sei que eu tenho direito e vou reivindicar.

O sentimento de não ser mais uma "formiguinha", sem dúvida é reforçado nas manifestações. Ao analisarmos o caso da marcha isso fica claro. Era impossivel estar sozinho em meio a 12 mil pessoas. A marcha se torna importante e visível por seu tamanho. Os sem-terra ali reunidos não eram pequenos.

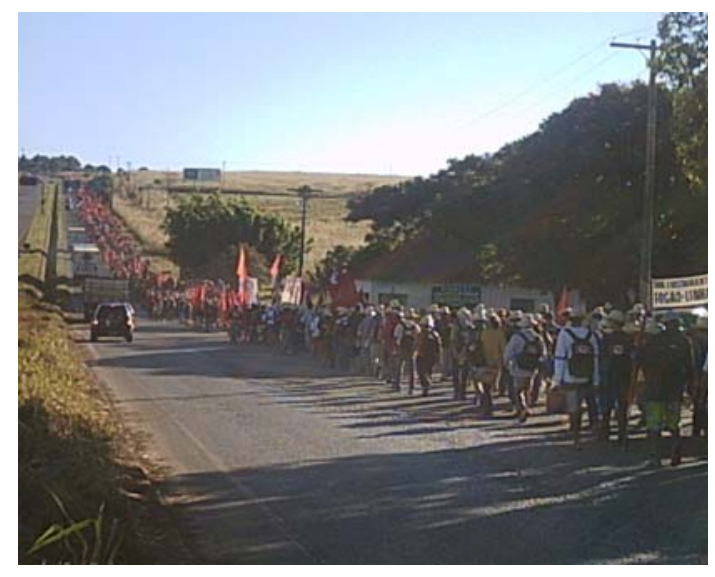

Marchantes atravessando a divisa entre os estado de Goiás e o Distrito Federal.

Os sem-terra na Esplanada dos Ministérios

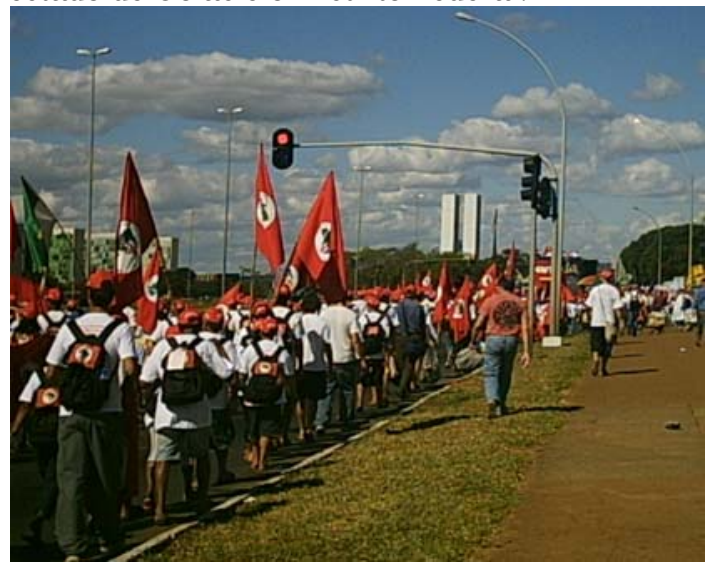
em Brasília.

Não estar sozinho é um grande atrativo para fazer parte do Movimento. Para os sociólogos Thye e Lawler: "Social movements may supply the opportunity to fulfill these demands and better they do, the more movement participation turns into a satisfying experience". ${ }^{232}$

Thye e Lawler se dedicaram ao estudo de grupos, relações sociais e mudanças a elas relacionadas e definiram que há uma distinção entre identidade individual e coletiva, sendo que a identidade coletiva é compartilhada por um grupo e é normalmente politizada. O indivíduo se dá conta dela na "luta com um inimigo", e com isso passa

\footnotetext{
${ }^{232}$ THYE, S. R. \& LAWLER, E. J. Social identification in groups. New York: Elsevier Jai, 2005, p. 153.
} 
a ocupar um lugar específico na sociedade. Sua participação no movimento social reforça seu pertencimento neste lugar. Ao mesmo tempo em que reforça a identidade coletiva e sua própria politização.

Complementariamente, pode-se dizer que, ao reforçar uma identidade politizada e um pertencimento, essas pessoas ficam sujeitas a uma leitura imposta pelo olhar do outro, como expressou Adelir:

Acho que em todos os momentos estou identificado com o Movimento. Isso porque a partir do momento que foi para um acampamento, tudo que fizer, tudo que falar, passa a não ser olhado unicamente como tu. Passa a ser olhado como parte daquele assentamento ou acampamento. Pois faz parte daquele acampamento.

Adelir sabe que os "de fora" vêem os sem-terra como grupo e tudo que for feito por um membro do grupo acaba reverberando para toda a coletividade. Queira ou não, fazer parte do grupo é ser um de seus representantes. A identidade coletiva implica em obrigações comportamentais e respeito a regras de convivio, que muitas vezes geram mudanças individuais. Assumir uma identidade é buscar o semelhante (o idem) e sentir-se acolhido, mas é também ser impulsionado à convivência com a diversidade e à prática da negociação constante para a definição de quem se é.

\section{Jogos de espelhos: historicizando identidade}

O conceito identidade tem uma longa história desenvolvida majoritariamente no campo da filosofia, que se dedicou a examinar a permanência em meio à mudança e a unidade frente à diversidade desde a antiguidade. Mais recentemente podemos relacionar o desenvolvimento do conceito frente às questões impostas pela modernidade e pelo individualismo.

Nos anos 50 do século passado, a busca por se saber quem realmente cada um é, passou a ser parte das preocupações e das bandeiras de luta de grupos sociais. O uso da palavra identidade, sem 
que houvesse um estudo teórico sobre ela, acabou gerando uma banalização de seu significado.

A psicologia também deu passos para a conceituação de identidade. Com destaque para os trabalhos de psicodinâmica desenvolvidos por Freud sobre identificação e de Lichtenstein, que se dedicou ao estudo de identidade como uma capacidade de continuidade frente à mudança constante ${ }^{233}$. Mas foi com o trabalho do psicohistoriador Erik Erikson que esses estudos passam a ter mais interface com as ciências sociais. Erikson desenvolveu estudos sobre "crise de idetidade" relacionados a soldados que retornavam da II Guerra Mundial e iniciou todo um debate em torno do sentido de continuidade histórica que o sujeito constitui ao participar de grupos ao longo da vida, abrindo caminho para os debates sobre múltiplas identidades. Importantes também foram as reflexões tecidas pelo psico-historiador em torno da questão do engajamento do sujeito em uma ideologia social mais abrangente que supra "uma necessidade psicológica universal de um sistema de idéias que proporcione uma imagem do mundo convincente"234. Essa idéia é bastante relevante, em especial para neste trabalho, pois vejo que o MST oferece essa identidade e essa imagem do mundo para seus componentes. Isso dá segurança, em um mundo tão cheio de incertezas, e permite a organização desse grupo, de suas pautas de reivindicações e de sua estratégia de resistência.

$\mathrm{Na}$ sociologia as discussões sobre identidade ficaram marcadas pelos trabalhos de George Herbert Mead, desenvolvidos na década de 1930. Com a delimitação de uma distinção entre "eu" e "eu mesmo" - self - Mead pôde definir identificação como um processo de outorga de nome, que faz com que cada um de nós coloque-se em categorias socialmente construídas, tendo a linguagem um papel importante nesse processo. ${ }^{235}$ Herdeiros mais recentes desse debate, Berger e Goffmann vão desdobrar essa discussão e propor o quanto a

\footnotetext{
${ }^{233}$ LICHTENSTEIN, H. The dilemma of human identity. New York: Jason Aronson, 1977.

${ }^{234}$ PLUMMER, K. Verbete: Identidade. In: OUTHWAITE, W. e BOTTOMORE, T. (orgs.). Op. Cit., p. 369, citando ERIKSON, E. Identity: youth and crises. S/d, 1968, p.31.

${ }^{235}$ MEAD, G. H. Mind, Self, and Society. Chicago: University of Chicago Press, 1934.
} 
identidade é socialmente outorgada, sustentada e transformada, reforçando o argumento de que as pessoas constroem suas identidades pessoais a partir dos grupos e culturas em que vivem. Nessa direção um paralelo interessante pode ser traçado entre a noção de como se constitui memória e como se constrói identidade ${ }^{236}$.

Tanto a sociologia quanto a psicodinâmica na modernidade preocupam-se com a fragmentação e a dissolução das comunidades, que faz com que as pessoas percam seu senso de pertencimento e de identidade, por isso mesmo a anomia, provocada pelas intensas transformações ocorrentes no mundo moderno, tem se tornado importante objeto de estudo no presente, seguindo as trilhas deixadas pelos sociólogos urbanos Simmel e Wirth.

Para Wirth, a dimensão da cidade, na esteira de Simmel, potencia tanto a autonomia dos indivíduos, como o seu anonimato e a perda do sentido de participação, podendo conduzir à anomia e ao vazio social. A densidade, por seu turno, na linha da tradição darwinista social, é tida como potenciadora do espírito de competição, mas também, da tolerância perante os outros. Por fim, a heterogeneidade, ao mesmo tempo em que instiga a necessidade de definição e delegação de interesses e o cosmopolitismo, é responsável pela insegurança dos indivíduos e confere à vida urbana um forte sentido de imprevisibilidade. 237

Mais recentemente a área que mais tem se dedicado aos estudos sobre identidade tem sido a antropologia. A lingüística também presta especial atenção a esse assunto, principalmente em estudos sobre a teoria da comunicação. Além de todas essas áreas da produção de conhecimentos nas ciências humanas, o surgimento dos Estudos Culturais marca a história do conceito de identidade e escritos de autores como Hall são muito importantes para sua revisão. Suas idéias relacionam identidade e diferença, ${ }^{238}$ apresentando identidade como

\footnotetext{
${ }^{236}$ BERGER, P. L. et LUCKMANN, T. A construção social da realidade, Petrópolis, Vozes. 1966, e GOFFMANN, E. Estigma: notas sobre a manipulação da identidade deteriorada. Rio de Janeiro: Zahar, 1982.

${ }^{237}$ FORTUNA, C. Cidade, cultura e globalização: estudos de sociologia. IN:www.ces.uc.pt/publicacoes/outras/199701/01introducao.php, acessado em 22/04/06.

${ }^{238}$ HALL, S., at alli. Identidade e diferença: a perspectiva dos estudos culturais. Petrópolis: Vozes, 2004.
} 
uma construção relacional, que necessita do diferente para se constituir.

As sociedades da modernidade tardia são caracterizadas pela "diferença"; elas são atravessadas por diferentes divisões e antagonismos sociais que produzem uma variedade de diferentes "posições de sujeito" - isto é identidades - para os individuos. Se tais sociedades não se desintegram totalmente não é porque elas são unificadas, mas porque seus diferentes elementos e identidades podem, sob certas circunstâncias, ser conjuntamente articulados. Mas essa articulação é sempre parcial: a estrutura da identidade permanece aberta. ${ }^{239}$

Hall vai além, na medida em que seus estudos retomam todo esse percurso do conceito e sintetizam explicações que aproximam a dinâmica dos significados estabelecidos pela língua da dinâmica social em busca de identidade. Para ele:

... os significados das palavras não são fixos, numa relação um-a-um com os objetos ou eventos no mundo existente fora da língua. O significado surge nas relações de similaridade e diferença que as palavras têm com outras palavras no interior do código da língua. [...] Observa-se a analogia que existe aqui entre língua e identidade. Eu sei quem "eu" sou em relação com o "outro" [...]. Como diria Lacan, a identidade, como o inconsciente, "está estruturada como a lingua". O que modernos filósofos da linguagem - como Jacques Derrida, influenciados por Saussure e pela "virada lingüística" argumentam é que, apesar de seus melhores esforços, o/a falante individual não pode, nunca, fixar o significado de uma forma final, incluindo o significado de sua identidade. As palavras são "multimoduladas". Elas sempre carregam ecos de outros significados que elas colocam em movimento, apesar de nossos melhores esforços para cerrar o significado. Nossas afirmações são baseadas em proposições e premissas das quais nós não temos consciência, mas que são, por assim dizer, conduzidas na corrente sanguínea de nossa língua. Tudo que dizemos tem um "antes" e um "depois" [...]. O significado é inerentemente instável: ele procura o fechamento (a identidade), mas ele é constantemente perturbado (pela diferença). Ele está constantemente escapulindo de nós. Existem sempre significados suplementares sobre os quais não temos qualquer controle, que surgirão e subverterão nossas tentativas para criar mundos fixos e estáveis. ${ }^{240}$

\footnotetext{
${ }^{239}$ HALL, S. A identidade cultural na pós modernidade. Rio de Janeiro: DP\&A, 2005, p. 17.

${ }^{240}$ Idem, p.40-1.
} 
A identidade aparece como o resultado de uma busca, uma ação em sentido contrário à instabilidade constante. Não é algo que se conquiste facilmente, tão pouco que não exija esforços para sua manutenção. É preciso vigilha constante. A diferença de ser despossuído, de não ter terra, que foi elemento de atração para o Movimento, internamente é insuficiente. Outras muitas diferenças surgem, de forma a concorrer ou suplementar o que inicialmente significou ser sem-terra. Isso causa nova instabilidade e mantém o movimento interno do grupo.

Teoricamente, identidade se tornou, em si, um assunto interdisciplinar que passou a ser estudado sob diversos prismas. Os historiadores, por sua vez, aproximam-se desse debate, impulsionados pelos ventos da interdisciplinaridade, mas também por toda a discussão geradas pelos pensadores ditos pós-modernos.

De maneira bastante breve, uma definição de pósmodernidade pode ser atribuída ao filósofo francês Jean-François Lyotard, em O pós-moderno (1988), que parte da análise do mundo ocidental em que vivemos nos termos que colocamos anteriormente. Considera-o como uma formação social na qual, sob o impacto do fim da predominância da influência religiosa, da democratização, da informatização e do consumismo, o mapa e o status do conhecimento estão sendo retraçados e redescritos.

Este ponto central da perspectiva de Lyotard é compartilhado, mesmo que com algumas oposições e diferenças, por autores como Jameson $^{241}$ e Giddens ${ }^{242}$, que usam as denominações capitalismo tardio ou modernidade tardia para enfatizar a decadência da sociedade capitalista. Igualmente, Bauman ${ }^{243}$ defende a idéia de uma modernidade líquida, ressaltando seus aspectos de instabilidade, insegurança, fluidez, gerados pelas mudanças velozes da sociedade capitalista. Lipovetsky ${ }^{244}$ define nosso tempo como sendo o da

\footnotetext{
${ }^{241}$ JAMESON, F. A cultura do dinheiro. Ensaios sobre a globalização. Petrópolis, RJ: Vozes, 2001.

${ }^{242}$ GIDDENS, Op. Cit., 1991, e GIDDENS, Op. Cit., 2002.

243 BAUMAN, Op. Cit, 2001.

${ }^{244}$ LIPOVETSKY, G. Os tempos hipermodernos. São Paulo: Ed. Barcarolla, 2004.
} 
hipermodernidade, caracterizando-o como típico da intensificação do liberalismo, da mercantilização, da exploração utilitarista e instrumentalizada da razão e do individualismo exacerbado. Por sua vez, Auge ${ }^{245}$ denomina de supermodernidade o contexto histórico contemporâneo, destacando traços como a proliferação dos não-lugares (supermercados, shopping centers, aeroportos, rodoviárias). Estes são espaços de não-vivência, mas apenas de consumo e passagem, um mundo provisório e efêmero, comprometido com o transitório e com a solidão. Para ele, os não-lugares são a medida de uma época que se caracteriza pelo excesso de informações e de fatos a serem compreendidos. Época esta caracterizada também pela superabundância espacial e pela individualização das referências, com a publicidade e a história aparentemente voltadas para cada indivíduo, mas contraditoriamente homogeneizadoras de todos.

O mundo tem acompanhado o surgimento de uma exclusão diferenciada e sistêmica. Em um balanço histórico contemporâneo, dessa época que se poderia chamar de pós-tudo (pós-liberal, pósocidental, pós-indústrial, pós-marxista, pós-moderna, pós-colonialista), as velhas teorias (eurocêntricas, positivistas, patriarcais, lineares) que legitimavam os velhos centros não podem mais ser reproduzidas de modo inconseqüente. Novas disputas estão sendo travadas no campo da história e a busca por uma "identidade" tornou-se arma na mão de grupos excluídos.

Segundo Burke a própria produção histórica iniciou seus trabalhos com o estudo das comunidades e apenas mais tarde começou a se preocupar com a identidade. ${ }^{246}$ Para a história, os conceitos identidade e comunidade estão muito próximos e devem ser tratados conjuntamente.

As reflexões sobre identidade se relacionam intimamente com comunidade. Como apontou Burke em um balanço sobre o conceito,

\footnotetext{
${ }^{245}$ AUGÉ, Op. Cit.

${ }^{246}$ Devo dizer que caminho semelhante foi percorrido por mim, no mestrado realizei um estudo sobre uma família e um assentamento do MST e agora debruço sobre a questão das identidades do mesmo movimento. BURKE, P. História e teoria social. São Paulo, Ed. Unesp, 2002, p. 166.
} 
comunidade tem desempenhado papel cada vez mais importante na escrita da história nos últimos anos, extrapolando assim as fronteiras dos estudos antropológicos e sociológicos. É verdade que estudos de comunidades são marcas da história há muito, mas esses eram feitos de forma a manifestar o orgulho local, aos poucos tais estudos foram promovendo um diálogo entre a micro e a macro análise. De qualquer forma Burke ressalta que:

O termo "comunidade", portanto, é ao mesmo tempo útil e problemático. Esse termo precisa livrar-se do pacote intelectual em que ele faz parte do consensual, o modelo durkheimiano de sociedade. [...] as comunidades precisam ser construídas e reconstruídas. E não se pode ter por certo que uma comunidade seja caracterizada por atitudes homogêneas ou esteja livres de conflitos. ${ }^{247}$

O processo de formação de uma comunidade é coletivo e continuo, sempre negociado entre coletividade e indivíduo. Dessas negociações constantes entre seus membros surge um sentimento de pertencimento à comunidade. Nesse sentido:

A comunidade é um lugar "cálido", um lugar confortável e aconchegante. É como um teto sob o qual nos abrigamos da chuva pesada, como uma lareira diante da qual esquentamos as mãos num dia gelado. Lá fora, na rua, toda sorte de perigo está à espreita; temos que estar alertas quando saímos, prestar atenção com quem falamos e a quem nos fala, estar de prontidão a cada minuto. Aqui, na comunidade, podemos relaxar - estamos seguros, não há perigos ocultos em cantos escuros (com certeza, dificilmente um "canto" aqui é "escuro").

Importante lembrar que ao entrevistar essas pessoas na marcha identificada por um crachá, como do Movimento, pude ter acesso a narrativas um pouco mais "relaxadas", embora com o peso do registro para a posteridade. Essas pessoas não falavam a qualquer um. Isso permitiu que se fossem feitas críticas que aqueles narradores pensavam que seriam compreendidas por mim, pois:

${ }^{247}$ Idem, p.86. 
Numa comunidade, todos nos entendemos bem, podemos confiar no que ouvimos, estamos seguros a maior parte do tempo e raramente ficamos desconcertados ou somos surpreendidos. Nunca somos estranhos entre nós. Podemos discutir - mas são discussões amigáveis, pois todos estamos tentando tornar nosso estar juntos ainda melhor e mais agradável do que até aqui e, embora levados pela mesma vontade de melhorar nossa vida em comum, podemos discordar sobre como fazê-lo. Mas nunca desejamos má sorte uns aos outros, e podemos estar certos de que os outros a nossa volta nos querem bem. ${ }^{248}$

Isso é o que ocorre internamente no Movimento. Quando críticas são feitas nas entrevistas elas aparecem com o objetivo de tornar o MST melhor e fazer dele um espaço de convivência em que pessoas de gêneros, raças de formações diferentes possa se sentir confortáveis e aconchegadas.

As discussões sobre os conceitos de identidade e de comunidade, no caso do MST, estão intimamente ligadas. Segundo os procedimentos da história oral adotados, ao se definir um grupo a ser pesquisado define-se uma comunidade de destino, ou seja, uma coletividade que partilha experiências, características e aspirações afins. Nessa pesquisa, considerou-se o MST como comunidade de destino, mas salienta-se que eles também consideram o MST como uma comunidade, a qual cada um dos colaboradores pertence. Assim a definição de comunidade para o Movimento não é alheia aos narradores, e respeita as próprias concepções do MST.

Além disso, importa lembrar o conceito de comunidade imaginada criado por Anderson, que define que uma comunidade se imagina em relação a um passado e ao futuro, sempre utópicos. Para o MST, portanto, a identidade Sem Terra constitui uma comunidade imaginada. ${ }^{249}$

Sobre o estudo do tema da identidade pode-se dizer que todas as áreas de estudo destacam a complexidade da noção de identidade,

\footnotetext{
${ }^{248}$ BAUMAN, Op. Cit., 2003, p. 7-8.

${ }^{249}$ ANDERSON, Op. Cit.
} 
sua enorme importância para a construção do sujeito e da cidadania. Em Identidade, o sociólogo Zygmunt Bauman afirma que o tema que é título de um de seus livros é um assunto intangivel e ambivalente no mundo da "modernidade líquida" onde tudo é precário e provisório. A ansiedade prevalece nos comportamentos humanos em virtude da dissolução de valores e referências que jogou homens e mulheres na permanente inconstância, sem possibilidade de estabelecer conexões entre si mesmos e o mundo na velocidade estonteante das mudanças engendradas pelo processo de globalização. Seu diagnóstico parece caminhar na mesma direção de Hall, em A identidade cultural na pósmodernidade, quando fala das mudanças de concepção de sujeito, especialmente ao falar do sujeito pós-moderno. No entanto, as palavras de Bauman soam mais cortantes. Talvez porque este autor coloque a frente de seu discurso uma questão mais política do que filosófica ou sociológica: a crítica ferrenha ao contexto de globalização capitalista está no centro de sua argumentação ${ }^{250}$.

Bauman afirma que esse panorama da globalização é radical e irreversivel, afetando todas as estruturas sociais e as relações que correspondem a elas. Nesse sentido, as identidades passam a ser consideradas cada vez mais como processos em permanente movimento, e a emergência das comunidades e das políticas de identidades como fenômenos de resistência, conservadora ou progressista, às conseqüências das transformações da globalização.

Dessa forma, qualquer discussão sobre identidades precisa conceber a ambivalência das políticas que elas podem gerar e os desdobramentos que essas ações coletivas podem desempenhar na vida privada e nos espaços públicos.

Bauman tenta definir um sentido para a construção de identidades através do reconhecimento da existência de comunidades de destino e de vida, concordando com S. Kracauer, compostas por pessoas que vivem juntas numa ligação absoluta ou então se fundem por idéias ou por uma variedade de principios. Bauman afirma que é a

${ }^{250}$ BAUMAN, Op. Cit, 2005a. 
partir das comunidades de segundo tipo que se torna mais consciente o fato de que as noções de pertencimento e de identidade são negociáveis e revogáveis e que as escolhas e as decisões que um indivíduo toma são fundamentais tanto para definir identidade como pertencimento. E aqui as reflexões de Bauman lembram as de Pollak, em "Memória e identidade social" 251 .

A memória é um fenômeno construído, social e individualmente, e segundo Pollak, sua construção pode ser consciente ou inconsciente, característica que, segundo Bauman, também pode ser atribuída ao conceito de identidade. O que a memória individual grava, recalca, exclui, relembra é evidentemente o resultado de um verdadeiro trabalho de organização. No caso de nossos trabalhos de pesquisa, somos mediadores dessa organização, ajudando o colaborador a organizar sua própria memória, e assim também a se organizar como coletividade em torno de um projeto ligado aos principios de um movimento social ou de um projeto político e econômico.

Para Pollak, há uma ligação fenomenológica muito estreita entre a memória e o sentimento de identidade. Ele afirma que trata o sentimento de identidade em um sentido superficial, da imagem de si, para si, e para os outros. Isto é, a imagem que uma pessoa adquire ao longo da vida referente a ela própria, a imagem que ela constrói e apresenta aos outros e a si própria, para acreditar na sua própria representação, mas também para ser percebida da maneira como quer ser. O autor recorre à psicologia social e a parte da psicanálise para definir três elementos essenciais na construção da identidade:

- a unidade física, ou seja, o sentimento de ter fronteiras físicas, no caso do corpo da pessoa, ou fronteiras de pertencimento ao grupo, no caso de um coletivo.

- a continuidade dentro do tempo, no sentido físico da palavra, mas também no sentido moral e psicológico.

- o sentimento de coerência, ou seja, de que os diferentes elementos que formam um individuo são efetivamente unificados (de tal forma esses elementos são importantes que se houver uma ruptura podemos observar fenômenos patológicos).

${ }^{251}$ POLLAK, Op. Cit., 1992, pp.200-212. 
A memória é um elemento constituinte do sentimento de identidade (individual e coletiva), na medida em que ela é também fator extremamente importante do sentimento de continuidade e de coerência de uma pessoa ou de um grupo em sua reconstrução de si.

O próprio Pollak admite que nessa sua definição de identidade social há um elemento que escapa ao indivíduo e por extensão ao outro. Ninguém pode construir uma auto-imagem isenta de mudança, de negociação, de transformação, em função dos outros. A construção da identidade é um fenômeno que se produz em referência aos outros, aos critérios de aceitabilidade, de admissibilidade, de credibilidade, e que se faz por meio de negociação direta com outros.

Memória e identidade podem perfeitamente ser negociadas, e não são fenômenos que devam ser compreendidos como essências de uma pessoa ou de um grupo. Se é possível o confronto entre a memória individual e a dos outros, isso mostra que a memória e a identidade são valores disputados em conflitos sociais e intergrupais, e particularmente em conflitos que opõem grupos políticos diversos. Constituem ponto importante na vida das pessoas e na disputa por valores familiares.

Ao falar de memória política como memória constituída, Pollak introduz o conceito de "trabalho de enquadramento da memória" 252 , em parte realizado por "historiadores orgânicos", isto é, inseridos dentro dos grupos e trabalhando em prol da construção das memórias e das identidades dos mesmos. As organizações políticas fazem esse trabalho com a finalidade de levarem os grupos a solidificar uma determinada consciência histórico-social. Há também o trabalho da própria memória em si, ou seja, cada vez que uma memória está relativamente constituída, ela efetua um trabalho de manutenção, coerência, unidade, continuidade da organização. Cada vez que a memória muda e se rearranja, as identidades coletivas também se transformam. O autor define identidade coletiva como todos os investimentos que um grupo

${ }^{252}$ POLLAK, Op. Cit. 1989 e POLLAK, Michael. Op. Cit, 1992. 
deve fazer ao longo do tempo, todo o trabalho necessário para dar a cada membro do grupo o sentimento de unidade, continuidade e de coerência. E, não podemos esquecer que segundo Stuart Hall, tal grupo parece ser analisado sob a concepção de um sujeito sociológico.

Hall mapeia as mudanças conceituais através das quais o sujeito do Iluminismo, tendo uma identidade fixa e estável, foi descentrando, resultando nas identidades abertas, contraditórias, inacabadas, fragmentadas, do sujeito pós-moderno:

O feminismo teve uma relação mais direta com o descentramento conceitual do sujeito cartesiano e sociológico.

- Questionou a clássica distinção entre o "dentro" e o "fora", o "privado" e o "publico". O slogan do feminismo era: "o pessoal é político".

- Abriu a contestação política, arenas inteiramente novas de vida social: a família, a sexualidade, o trabalho doméstico, a divisão doméstica do trabalho, cuidado com as crianças etc...

- Enfatizou, como uma questão política e social, o tema da forma como somos formados e produzidos como sujeitos generificados. Isto é, politizou a subjetividade, a identidade e o processo de identificação (homem $\backslash$ mulheres $\backslash$ mães $\backslash$ pais $\backslash$ filhos $\backslash$ filhas)

- Expandiu-se para a formação das identidades sexuais e de gênero.

Questionou a noção de que os homens e as mulheres eram parte da mesma identidade, a "humanidade", substituindo-a pela questão da diferença sexual. ${ }^{253}$

Num mundo fragmentado como o nosso, dos sujeitos pósmodernos de Hall, as pessoas estão às voltas com uma sobrecarga de identidades, sem conseguir enxergar quais são as que realmente importam para si e quais são as que se apresentam lançadas pelas pessoas em volta. Por isso, a negociação será permanente.

Bauman cita as encruzilhadas culturais, a continua transgressão e expansão de fronteiras como fatores típicos do nosso tempo e que vão também caracterizar a mobilidade das identidades, sua permanente invenção, sempre decorrente de muito esforço e a ser eleita como objetivo de muitos agrupamentos humanos. Assim, no ambiente de desintegração da modernidade liquida, a identidade torna-se um

${ }^{253}$ HALL, Op. Cit., 2005, p. 45. 
problema, uma tarefa, um projeto de vida. Tarefa antes monopolizada pelo Estado-nação, que se incumbia de dar estabilidade às identidades prioritariamente nacionais para que ele próprio pudesse nascer e se desenvolver, de acordo com as reflexões de Agamben.

Torna-se importante salientar esse trecho sobre a identidade nacional, pois é nele que Bauman afirma de maneira mais enfática seu caráter de construção ao destacar o quanto de coerção e de convencimento foram necessários para que ela se constituísse enquanto tal, em nascimento simultâneo com o Estado moderno. E especialmente como essa identidade nunca permitia que outras tivessem estatuto semelhante, não reconhecendo competidores - que dirá opositores -, sendo cuidadosamente construída através de vários mecanismos que, ao mesmo tempo, a naturalizavam como não-construção, a qual era impossível não aderir.

Bauman cita alguns clássicos da Sociologia, como Durkheim, para dizer o quanto não podem servir de parâmetro para as análises atuais, apesar de seu trabalho se inspirar em visões de importantes trabalhos da área, como os de Simmel e de Goffman. Além disso, o autor afirma que outros pensadores como Lucaks ou Marx, forjaram suas análises da sociedade a partir de identidades mais ou menos estáveis que hoje perderam boa parte de seu poder de constrangimento ou convencimento, visto que as identidades ganharam livre curso. A identidade central forjada pelo MST vive a contradição desse debate: almejando a estabilidade de uma plataforma para a luta política, se depara com a fluidez das múltiplas identidades e dos papéis sociais.

Vale lembrar que o uso político de identidade marcou os anos de 1960. A política identitária ligada a minorias étnicas, religiosas, bem como aos movimentos feminista ou homossexual, fizeram com que esses grupos, baseados em suas experiências de opressão e exclusão, criassem uma identidade grupal distinta, em torno da qual se buscou apoio para mudança social e política. A contradição está no processo de luta desses grupos. Contradição gerada pelas mudanças políticas ocorridas na contemporaneidade. De início eles, assim como também o 
MST, se organizaram em torno do modelo marxista, à medida que eram um grupo subordinado que desenvolvia uma consciência e a partir dela se organizava para a ação politica - isso poderia até mesmo ser caracterizado como consciência de classe. Nos anos 1980 e 1990, a luta de classes é relida pela renovação dos movimentos sociais e do sindicalismo, que passa a abraçar novas causas como a ecologia e as questões de gênero. Assim, o MST vivenciou, em seus pouco mais de 20 anos de existência, esse fluxo e esse refluxo. Perto do final do século XX as politicas de identidade já eram vistas como um padrão para as conquistas do futuro.

Dentro do Movimento vê-se essas duas tendências, que caminham lado a lado na maioria das vezes, mas que entram em choque em disputas internas, principalmente nas definições de linhas de ação ou de agendas reivindicatórias de políticas públicas.

No contexto histórico contemporâneo, emergiram então as batalhas por reconhecimento travadas de forma individual ou coletiva. Essas batalhas se dão em torno de identidades escolhidas e preferidas sempre contrapostas àquelas impostas (estereótipos, estigmas, rótulos), antigas, abandonadas ou abominadas. No caso dos membros do MST, nossos narradores abrem mão de suas identidades de "bóia fria", "trabalhador rural sem terra", desempregado do passado para agora se dizerem Sem Terra, lutando por dar um significado diferenciado a esse nome, e encarando junto o preconceito que os "de fora" têm em relação a eles.

Pessoas que vivem em condições de exclusão são consideradas, nas palavras de Bauman, "vidas desperdiçadas", ou "lixo humano". ${ }^{254}$ São pessoas rejeitadas, não necessárias ao funcionamento da economia capitalista global. Para o autor, é essa exclusão, mais do que a exploração, como Marx afirmava, que está na base do aprofundamento da polarização social, da miséria, da desigualdade e da humilhação. Nesse contexto é que o autor explica a ascensão dos fundamentalismos.

${ }^{254}$ BAUMAN, Z. Vidas desperdiçadas. Rio de Janeiro, Jorge Zahar Ed. 2005b. 
Nesse mesmo sentido pode-se destacar o trecho em que Wanderléia afirma: "Agora sim, eu me sinto gente! Me sinto uma pessoa de verdade, um ser humano! Me sentia um lixo antes de entrar para o Movimento... Agora me sinto um ser humano, uma pessoa de verdade." Essa identidade aflora de tal forma, que ela chega a dizer: "o sangue do MST corre na minha veia". E completa:

E quando estou nas manifestações me sinto... nossa me sinto enfeitiçada! Me sinto gente! Quando estou no Movimento, me sinto importante! Cada um de nós aqui é importante! O calor humano que tem entre nós!...

Essa é uma colocação fundamental para que se perceba o alcance da sensação de pertencimento de Wanderléia, e de sua crença na transformação do mundo e da sociedade.

A crença na transformação da sociedade, comum a muitos sem-terra, concretiza, segundo Castells, uma identidade de projeto. ${ }^{255} \mathrm{~A}$ construção da identidade para o autor organiza significados e depende da matéria-prima proveniente da cultura obtida, processada e reorganizada de acordo com a sociedade. Dessa forma categorizam-se três tipos identitários:

- Identidade legitimadora: introduzida pelos dominantes para expandir e racionalizar sua dominação em relação aos demais atores sociais;

- Identidade de resistência: criada por atores contrários a dominação atual, criando resistências com princípios diferentes ou opostos aos da sociedade em que vivem;

- Identidade de projeto: quando os atores constroem uma nova identidade para redefinir sua situação na sociedade ou a própria sociedade.

Castells pondera que uma identidade de resistência pode acabar como de projeto ou até mesmo legitimadora, se aceitar a dominação.

\footnotetext{
${ }^{255}$ CASTELLS, M. O poder da identidade. Coleção A Era da Informação: Economia, Sociedade e Cultura, Volume 2. São Paulo: Paz e Terra, 2006, 24.
} 
Apresento a hipótese de que a constituição de sujeitos, no cerne do processo de transformação social, toma um rumo diverso do conhecido durante a modernidade dos primeiros tempos e em seu período mais tardio, ou seja, sujeitos, se e quando construidos, não são mais formados com base em sociedades civis que estão em processo de desintegração, mas sim como um prolongamento da resistência comunal. Enquanto na modernidade a identidade de projeto fora constituída a partir da sociedade civil (como, por exemplo, no socialismo, com base no movimento trabalhista), na sociedade em rede a identidade de projeto, se é que se pode desenvolver, origina-se a partir da resistência comunal. É esse o significado real da nova primazia da politica de identidade na sociedade em rede. ${ }^{256}$

Seguindo esse raciocinio, acredita-se que a identidade oficial forjada pelo MST é uma identidade, que, por seus desdobramentos pode ser considerada como de projeto, pois é esse tipo de identidade que se desenvolve a partir de uma identidade de resistência que extrapola a ação defensiva e que tem como principal objetivo a reestruturação de uma estrutura social.

As pessoas entrevistadas em suas narrativas mostram a necessidade de assumir a (re)construção das identidades como tarefa permanente, como projeto de vida, num contexto de resistência à exclusão e à marginalidade. Identidade aqui compreendida como processos em que a noção de pertencimento e de continuidade histórica dos grupos sociais são construídas em meio a lutas sociais, políticas e econômicas e suas contradições e ambigüidades.

Nesse sentido, ao se registrar as entrevistas desses colaboradores, contribui-se com essa tarefa de (re)construção identitária abraçada por eles - o pesquisador queira ou não, concorde ou não. Sendo assim, cabe uma autocritica, pois algumas vezes, podese enxergar nesse trabalho a contradição criticada por Hall, em que o pesquisador, na concepção de um sujeito iluminista, dotado de razão e

${ }^{256}$ Idem, p. 28. 
de coerência, passa a buscar essa mesma lógica em seus colaboradores, nos movimentos sociais.

Dessa forma, transita-se na prática de pesquisa entre as concepções de sujeito iluminista e pós-moderno, tentando enxergar como os sujeitos/colaboradores de fato existentes, vão construindo assim como o próprio pesquisador - de forma ambígua, contraditória e bastante fluida suas identidades a partir de subjetividades muito mais complexas do que podemos teorizar ou categorizar. Vale lembrar que:

A formação do eu no "olhar" do outro, de Lacan, inicia a relação da criança com os sistemas simbólicos fora dela mesma, o momento da sua entrada nos vários sistemas de representação simbólica - incluindo, língua, cultura e a diferença sexual. Os sentimentos contraditórios e não resolvidos que acompanham essa dificil entrada, são aspectos chave da "formação inconsciente do sujeito" e que deixam o sujeito "dividido", permanecem com a pessoa por toda a vida, embora o sujeito esteja sempre dividido ou partido, ele vivencia sua própria identidade como se ela estivesse reunida e "resolvida", ou unificada, como resultado da fantasia que ele formou na fase do espelho, de acordo com esse tipo de pensamento psicanalítico, é a origem contraditória da "identidade". 257

Ao levar em conta essa complexidade da formação identitária, é preciso considerar que não há uma coincidência pura e simples entre identidades e subjetividades, como alguns trabalhos nos fazem crer. Muitos trabalhos e muitos grupos que falam de identidades anulam subjetividades, ao homogeneizar idéias, padronizar procedimentos e transformar processos múltiplos em lineares, apagando as contradições. Comumente, essas homogeneizações eram estabelecidas a partir do padrão da sociedade ocidental judaico-cristã que de forma geral tendeu à valorização da história do homem branco. Ao se propor entender a sociedade em sua heterogeneidade, e em suas contradições, declara-se a "morte do sujeito universal", da qual nos falou Hall, que estabeleceu por tanto tempo um referencial de construções narrativas e analiticas.

\footnotetext{
${ }^{257}$ HALL. Op.cit., 2005, p.37.
} 
Muitas necessidades, múltiplas identidades

Ao ler as histórias de vida presentes nesse trabalho pode-se compreender que vários dos narradores apontam sua entrada no MST e sua adesão à identidade oficial do Movimento como formas de fugir desses estereótipos da exclusão, abraçando um outro "estereótipo", muitas vezes também excludente. A diferença é que agora não se sentem sozinhos mais, e, portanto, estão incluídos em alguma parcela de nossa sociedade, mesmo que ainda excluídos num espectro maior.

Em geral, essas pessoas são consideradas como pertencentes a uma "subclasse", sempre inferiores na hierarquia de poder e seus protestos raramente serão ouvidos. Bauman afirma que a maioria das pessoas "paira" entre esses pólos, o do reconhecimento e o da exclusão, vivendo em constante deslocamento, ansiedade, opressão e medo, visto que essas identidades de "subclasses" que se configuram nos limites da sociedade existente constituem-se principalmente como ausência de identidade. É natural pensar que ninguém quer viver assim, por isso uma identidade central forte se torna tão atrativa.

Nesse contexto, nega-se a individualidade e inclusive as possibilidades de afirmá-la, pois essas pessoas são excluídas do espaço social que possibilita afirmá-las, buscá-las, escolhê-las, construí-las, refutá-las ou avaliá-las. E isso acontece tanto no contexto da exclusão fora do MST, quanto na opção por assumir uma identidade oficial "Sem Terra" e sem criticas.

Nesse sentido remete-se às palavras do antropólogo Bruner, ao referir-se a etnografia como narrativa:

... we begin with a narrative that already contains a beginning and an ending, which frame and hence enable us to interpret the present. It is not that we initially have a body of data, the facts, and we then must construct a story or a theory to account for them. [...] the narrative structures we construct are not secondary narratives about data but primary narratives that establish what is to count as data. New 
narratives yield new vocabulary, syntax, and meaning in our ethnographic accounts; they define what constitute the data of those accounts. [...] My focus is on our talk about Indians, not on Indians life itself. Our anthropological stories about Indians are representations, not be confused with concrete existence or "real" facts. In other words, life experience is richer than discourse. ${ }^{258}$

Para entender melhor a ligação entre memória, narrativa e identidade pretende-se também avançar na discussão sobre formas de uso da história oral e compreender como isso se dá na prática, na negociação entre memória de luta e contínua construção de uma identidade Sem Terra.

Identidade esta que se constrói sobre a base da experiência vivida, sentida e memorizada por seus integrantes. Mas, não só. Constrói-se também pelo reviver ou recriar proporcionado pela narrativa de alguns de seus membros. Daí a importância de se estudar a questão da memória, a qual se tem acesso por meio do registro das narrativas, para se entender a identidade Sem Terra.

Quando se fala em narrativa é importante marcar que o tempo trabalhado por ela é o tempo do presente, assim a leitura das histórias de vida remete a uma leitura da memória que essas pessoas têm de sua vivência no MST, e não a história deste movimento. A história oral não produz documentos sobre o passado e sim em diálogo com ele, à luz da circunstâncias do tempo presente.

O que, no entanto, significa definir este como um trabalho de história do tempo presente? Ferreira afirmou que a "chamada 'história do tempo presente' passou das margens do campo histórico para o centro da disciplina”. Além disso, a historiadora analisou que com o uso da história do tempo presente mudou o fazer do historiador, pois:

A valorização de uma história das representações, do imaginário social e da compreensão dos usos políticos do passado pelo presente promoveu uma reavaliação das relações entre história e memória e permitiu aos historiadores repensar

\footnotetext{
${ }^{258}$ BRUNER, E. M. Ethnography as narrative. IN: TURNER, V. W. and BRUNER, E. M. (org). The anthropology of experience. Chicago: University of Illinois Press, s/d, p. 142-143.
} 
as relações entre passado e presente e definir para a história do tempo presente o estudo dos usos do passado. ${ }^{259}$

O historiador francês Rémond alertou que a história do tempo presente tem efeitos sobre a percepção que os historiadores têm sobre seu trabalho. De modo que chegou a afirmar:

Creio que os efeitos podem ir além e contribuir para modificar a idéia que o historiador faz de seu papel e de seu oficio. [...] Cuidemos para não nos transformarmos em corporação, a história não nos pertence, ela pertence a todos, aos magistrados como aos cidadãos. É um bem comum, cada um tem direitos sobre sua história e devemos ser os representantes da sociedade. Cuidemos para não nos apropriarmos da história. A reintegração do tempo presente faz varrer da visão da história os últimos vestígios do positivismo: o historiador do tempo presente sabe o quanto sua objetividade é frágil, que seu papel não é o de uma chapa fotográfica que se contenta em observar fatos, ele contribuiu para construí-los. ${ }^{260}$

Rémond destacou que a história do tempo presente muda também a noção que os historiadores têm sobre o período histórico que estudam. Defendendo que a história do tempo presente "é um bom remédio contra a racionalização a posteriori, contra as ilusões de ótica que a distância e o afastamento podem gerar."261

Assim, lança-se um olhar sobre a história recente do Brasil, tendo como recorte o envolvimento de diversos sujeitos com o Movimento Sem Terra, motivando um estudo sobre identidade, impulsionado por preocupações do presente.

As narrativas muitas vezes repetem experiências semelhantes de expulsão 262 do campo e busca por um lugar na cidade. Sob o ponto de vista teórico, defende-se que os conceitos de memória, narrativa e identidade são interdependentes. Não se pode pensar a identidade de

\footnotetext{
${ }^{259}$ FERREIRA, M. M. História, tempo presente e história oral. Disponível em: http://www.ifcs.ufrj.br/ ppghis/pdf/topoi5a13.pdf, p. 8, acessado em 28/05/07.

${ }^{260}$ RÉMOND, R. Algumas questões de alcance geral à guisa de introdução. IN: FERREIRA, M. M. \& AMADO, J. (orgs). Op. Cit., 1998, p. 208.

${ }^{261}$ Idem, p. 209.

${ }^{262}$ Uso a palavra expulsão, pois não acredito nessa migração campo cidade como um processo voluntário, e sim fruto da política de desenvolvimento violenta, elitista e por vezes omissa que os governos assumem com relação ao campo brasileiro.
} 
um grupo sem refletir sobre sua memória narrada. Dessa forma, memória, narrativa e identidade são conceitos complementares para essa tese e estão sendo tratados em conjunto.

As múltiplas identidades (de gênero, de procedência, de raça, de religiosidade) presentes nas vidas dos sem-terra compõem uma identidade coletiva, entretanto é importante notar que nem sempre reforçam a identidade central que o Movimento quer criar. As tramas biográficas dão acesso às escolhas feitas, aos conflitos, ou às divergências que aconteceram em nivel particular, e acabam por se refletir nas identidades do grupo, mas também a contestam e a modificam.

Nessa direção retoma-se uma reflexão de Bhabha, que definiu a noção de diferença cultural:

A diferença cultural, como uma forma de intervenção, participa de uma lógica de subversão suplementar semelhante às estratégias do discurso minoritário. A questão da diferença cultural nos confronta com uma disposição de saber ou com uma distribuição de práticas que existem lado a lado, abseits, designando uma forma de contradição ou antagonismo social que tem que ser negociado em vez de negado. [...] O objetivo da diferença cultural é rearticular a soma do conhecimento a partir da perspectiva da posição de significação da minoria, que resiste à totalização - a repetição que não retornará como o mesmo, o menos-na-origem que resulta em estratégias politicas e discursivas nas quais acrescentar não soma, mas serve para perturbar o cálculo de poder e saber, produzindo outros espaços de significação subalterna. ${ }^{263}$

Seria interessante mostrar que a "diferença cultural" pode ser percebida tanto de fora para dentro, como interna ao Movimento. A produção de outros espaços de significação subalterna é necessária, pois relações hierárquicas e de poder muitas vezes são reproduzidas internamente. Elas são evidenciadas no discurso no uso de palavras como "chefismo", com a qual Elizandra define algumas relações de trabalho estabelecidas dentro do Movimento.

${ }^{263}$ BHABHA, Op. Cit, p. 228. 
Para além disso, Bhabha ainda afirma que:

[O sujeito do discurso da diferença] é constituído através do locus do Outro, o que sugere que o objeto de identificação é ambivalente e ainda, de maneira mais significativa, que a agência de identificação nunca é pura ou holística, mas sempre constituída em um processo de substituição, deslocamento ou projeção. [...] As designações da diferença cultural interpelam formas de identidade que devido a sua implicação contínua em outros sistemas simbólicos, são sempre "incompletas" ou abertas à tradução cultural. ${ }^{264}$

Com base nessas afirmações pode-se traçar um paralelo com a prática de pesquisa aplicada neste trabalho, pois:

Em história oral, o "grupal", "social" ou coletivo não corresponde à soma dos particulares. A observância em relação à pessoa em sua unidade é condição básica para se formular o respeito à experiência individual que justifica o trabalho com o depoimento. Nesse sentido, a história oral é sempre social. Social, sobretudo, porque o indivíduo só se explica na vida comunitária. Daí a necessidade de definição dos ajustes identitários culturais. 265

Cada pessoa é composta por muitas identidades, pois cada um guarda em si sua etnia, seu gênero, sua geração, sua classe social, sua religião, sua cultura etc. Para fazer parte de um ou outro grupo essa pessoa estabelece um diálogo que implica escolhas e conseqüentemente renúncias, o que gera mudanças no seu modo de se ver o grupo e no modo do grupo ver essa pessoa.

A "multiplicidade de identidades" implica negociações permanentes, requalificação dos pressupostos originais e reafirmação diuturna dos pólos identitários, exigindo escolhas, sempre com opções criteriosas. ${ }^{266}$

Para entender a idéia de identidades múltiplas talvez valha uma referência ao conceito de bricolagem. Pensar a identidade como sobreposição de várias identificações parece ser um caminho viável. Os sem-terra não perdem suas identidades anteriores ao assumir a

\footnotetext{
${ }^{264}$ Idem, ibdem.

${ }^{265}$ MEIHY, J. C. S. B. Manual de história Oral. São Paulo, Loyola, 2002, p.68.

${ }^{266}$ MEIHY, Op. cit., 2002, p.74.
} 
identidade oficial. Essa é mais uma das múltiplas identidades que formam cada um deles. Continuam sendo homens, mulheres, brancos, negros, pernambucanos, paulistas, gaúchos... O que parece estar sendo construído é uma identidade "transidentitária" ou, como apontaram estudiosos da imigração, identidades negociadas ${ }^{267}$. Um teto que abriga uma diversidade identitária.

Um estudo sobre a identidade dos jovens no MST, realizado por Branco, afirma que:

Os diferentes espaços da vida cotidiana moderna - na qual o ser humano aparece como fragmentado, porque experimenta as contradições vivas da sua existência social de diversas formas, em vários lugares (no trabalho, no bairro, na rua e na família) e em diferentes posições (de classe, de parentesco, de gênero, de etnia, de geração) - não produzem identidades retalhadas, mas compõem um sistema contraditório de referências, em que diversas representações e sentimentos entram em luta constante e produzem identidades sempre em mutação.

A identidade, tanto pessoal como social, deve ser considerada como um processo e não um produto acabado, com o pessoal e o social sendo interdependentes, gerando, em determinado momento do ciclo vital, ou da história do grupo social, um sentimento de integridade, unicidade e, ao mesmo tempo, de pertença a um grupo, nação ou espécie. 268

Dessa dinâmica, bastante fluída, surgem as múltiplas identidades, pois cada pessoa pertence ao mesmo tempo a várias comunidades ou grupos.

Poucos de nós, se é que alguém, são capazes de evitar a passagem por mais de uma "comunidade de idéias e princípios", sejam genuínas ou supostas, bem-integradas ou efêmeras, de modo que a maioria tem problemas em resolver (para usar os termos cunhados por Paul Ricoeur) a questão da la mêmete (a consciência e continuidade da nossa identidade com o passar do tempo). Poucos de nós, se é que alguém, são expostos a apenas uma "comunidade de idéias e princípios" de cada vez, de modo que a maioria tem problemas semelhantes

\footnotetext{
${ }^{267}$ LESSER, J. A negociação da identidade nacional: imigrantes minorias e a luta pela etnicidade no Brasil. São Paulo: Editora UNESP, 2001.

${ }^{268}$ BRANCO, M. T. C. Jovens sem-terra: identidades em movimento. Curitiba: Ed. UFPR, 2003, p.155/156.
} 
com a questão da l'ipséite (a coerência daquilo que nos distingue como pessoas, o que quer que seja). ${ }^{269}$

Pensa-se os processos de identificação dos sem-terra como algo negociado, e em marcha. É certo que nem tudo o que se tem hoje foi resultado de negociação com as bases. Por vezes, definiu-se um modo de ser, que não respeitou essa diversidade, o que tornou violento o processo. Por isso, vê-se surgir processos de resistência e mudança dentro do próprio Movimento, que se vê obrigado a repensar algumas de suas idéias, à luz do cotidiano de assentados e acampados.

As várias expectativas e as relações entre lideranças e bases envolvidas no processo de identificação com o MST são abordadas por Branford e Rocha:

Embora o sem-terra possa dizer que só quer um lote, esse pedaço de chão tem sido sempre um símbolo de seus anseios por uma vida diferente, na qual ele e os filhos possam ter melhores oportunidades de se realizarem e de serem aceitos como cidadãos. Terra para eles é a terra prometida e para conquistá-la, os sem-terra têm se disposto a enfrentar a fome, a repressão e a perseguição. Desde a fundação do movimento, o desejo dos camponeses de conquistar a terra e a inclusão na sociedade coexistiu, às vezes não sem conflito, com os objetivos de muitos dos líderes, que querem transformar o MST num movimento revolucionário de acordo com a tradição leninista. Não nos parece correto acusar os líderes de estar manipulando cinicamente familias camponesas ignorantes, visando a seus próprios fins políticos, como diversos intelectuais de direita já apontaram. O que está ocorrendo é mais complexo do que isso: muitos líderes acreditam que os sem-terra só conquistarão a terra almejada, nas condições desejadas, se o movimento conseguir de fato redistribuir poder político no Brasil. E, segundo eles, isso requer algum tipo de revolução. ${ }^{270}$

Nesse trecho Branford e Rocha apontam para a existência de diferentes idéias, representadas pela posição dos "líderes" em contraponto com a das "famílias de camponeses", dentro do MST. Uma identidade revolucionária, marxista, levada adiante por parte das lideranças e uma outra de caráter mais tradicional, emblemada na luta

\footnotetext{
${ }^{269}$ BAUMAN, Op. Cit., 2005b, p.19.

${ }^{270}$ BRANFORD e ROCHA, Op. cit., p. 323/4.
} 
dos camponeses. Essas duas se complementam e se alteram, pois o Movimento é formado na interação de seus componentes. Por isso, vemos constantemente a formação e a transformação de uma prática em que se cria uma identidade do Movimento em movimento.

Cabe dizer que o tema da identidade "Sem Terra" é tratado, mesmo que não de forma central, em vários trabalhos sobre o MST. São textos produzidos por lideranças como Ademar Bogo, Roseli Caldart e João Pedro Stédile, ou mesmo por acadêmicos como Bernardo Fernandes, que reconhecem a importância dessa questão.

Ausências e emergências: subjetividades e identidades

Ao falar de identidade gostaria de lembrar um pouco sobre minhas identidades assumidas durante essa pesquisa. Por vezes fui considerada uma pesquisadora "de dentro", ou seja, ao receber o uniforme e compor um dos setores da marcha fui "promovida" a membro do MST. Entretanto não posso esquecer que em outros momentos fui “de fora”. É claro que ao entrar nessa comunidade recebi credenciais, porém nunca me senti “de dentro", por ter em mente a distância entre minha experiência de vida e a daquelas pessoas. O estranhamento esteve sempre presente.

Tal reflexão, sobre um posicionamento frente à pesquisa, revela como se constroem minhas próprias identidades e memórias, enfim lidando com a complexidade das subjetividades no contexto da modernidade liquida. Afinal, pesquisador algum "paira" sobre a realidade, sobre os colaboradores ou mesmo sobre os discursos da história e das humanidades. O simples reconhecimento do lugar que se (des)constrói cotidianamente junto às pessoas com os quais se trabalha pode tornar mais evidentes quais são as tarefas e os projetos de vida que se abraçou e evidenciar a definição de uma identidade como tarefa.

O sujeito não só tem experiências como pode comunicá-las, construir seu sentido e ao fazê-lo, afirmar-se como sujeito. A 
memória e os relatos de memória seriam uma "cura" da alienação e da coisificação. Se já não é possivel sustentar uma Verdade, florescem em contrapartida verdades subjetivas que afirmam saber aquilo que, até três décadas atrás, se considerava oculto pela ideologia ou submerso em processo pouco acessiveis à simples introspecção. Não há Verdade, mas os sujeitos, paradoxalmente, tornam-se cognisciveis. ${ }^{271}$

De qualquer forma, penso que a subjetividade do entrevistador fica expressa na interação com a do entrevistado. Este, portanto, é um trabalho que apresenta um resultado acadêmico, ao mesmo tempo em que tem um resultado muito pessoal. Penso aqui em intersubjetividade não como um aspecto do encontro de dois indivíduos, mas como algo essencial que deu significado particular a existência das relações de dois sujeitos.

E os sem-terra? Quais identidades assumiram durante essa pesquisa?

Em primeiro lugar, eles falaram do seu cotidiano antes de entrar no MST: suas relações familiares, com destaque para as relações de gênero, com a condição subalterna da mulher no interior da família de pequenos agricultores, no campo ou na cidade, temas conhecidos da realidade histórica brasileira contemporânea. Em seguida contaram da construção de identidades individuais e coletivas, como a identidade feminina ou masculina ou a identidade política e cultural, que aos poucos se contrapõem ao contexto anterior, na fala e na prática.

É impossível entender essa "filiação" ao MST sem pensar na subjetividade vista como um conjunto de fatores pessoais que torna aquela vida única, pois só ela teve aquela exata vivência que cria uma narrativa e, portanto, aquelas identidades. "Valeu a pena" ou "minha vida mudou" ao entrar no MST é o comum da retórica dos sem-terra. Segundo Adelir:

Acho que minha vida mudou muito. A gente costuma dizer que se hoje tem a terra, o local para plantar, a vaca para tirar o leite, a casa para morar... Tem tudo isso porque a organização fez com que tivesse. Lógico que cada um de nós

${ }^{271}$ SARLO, B. Op. Cit., 2007, p. 39. 
fez a sua parte, mas quem possibilitou foi ela. Não conseguimos imaginar como seria fora dela. Com certeza, as dificuldades seriam muito maiores. Como eu colocava que houve a separação do meu pai e da minha mãe e que a gente era pequeno... Na cidade, não teria nenhuma possibilidade da nossa mãe ter dado uma condição de vida melhor para nós, do que conseguiu no Movimento. Porque dentro do Movimento além de tu estar vivendo um pouco na terra em que era acostumado a viver, o conjunto, o acampamento, as pessoas que te cercam também contribuem para educação, para formação, para o crescimento... Às vezes, lá na cidade, não teria isso. Se a mãe fosse trabalhar de empregada certamente a gente iria ficar sozinho.

Para essas pessoas, justificar sua entrada no MST é dificil, pois esta participação impõe a consciência de um estigma, implica em um posicionamento que é visto com muita ressalva. Tais pessoas encaram o preconceito ao se depararem com o discurso hegemônico, em nossa sociedade, que quase sempre associa a ação deste movimento social com situação de ilegalidade. Essa dificuldade é expressa por Daniel na seguinte passagem:

Acho que comecei a ver essas coisas no decorrer do tempo, porque no começo eu tinha vergonha de ser sem-terra. Eu ia para casa no final de semana, e eu tinha vergonha... eu era bastante criticado, eles ficavam zombando. Mas depois, com o que a gente passa dentro do acampamento, vai aprendendo. A gente vai se descobrindo por esse senso crítico das coisas. Passa a pensar que "morava lá no interior, perdeu a terra", e se pergunta, "mas por que perdeu a terra?" Será que perdeu por perder ou teve influência de alguma coisa? Eu acho que foi isso que fui percebendo.

A questão de como eles são vistos aparece em várias entrevistas. Mesmo ao se afirmarem como Sem Terra e dizerem não ter vergonha de se apresentar como tal, alguns apontam que sabem que não serão bem tratados depois de se apresentarem assim. E completam que esse é um enfrentamento necessário para que se mude a imagem que se tem dos sem-terra. Essa discussão remete à reflexão sobre a força do olhar externo sobre a construção da imagem do sujeito ou de seu grupo identitário. Principalmente se esse olhar tem a mídia a seu 
favor. Por isso é interessante ver que vários militantes estão empenhados em que os "outros" tenham uma visão positiva deles.

Paralelamente, para pertencer a um grupo, e se manter nele, é exigido um padrão de comportamento. A identidade construída coletivamente faz imposições, as pessoas do grupo cobram um comportamento que é o de representante. No limite, uma identidade criada para superar a exclusão pode igualmente se tornar excludente e intolerante. Em alguns casos nota-se que comportamentos desviantes também são punidos, e o próprio Movimento, estabelecendo limites, exclui pessoas do relacionamento naquela comunidade. Casos assim se repetem em assentamentos e principalmente em acampamentos relacionados à questão do alcoolismo e da dependência de drogas, o que no limite pode acarretar em expulsão.

A esse respeito, apresenta-se um trecho da entrevista de Pedro, coordenador de seu acampamento no Tocantins, que não faz parte do conjunto de narrativas apresentadas no início desta tese, mas que como compôs o trabalho de campo, certamente inspirou reflexões que agora se fazem presentes:

No acampamento aparece vários tipos de problemas para o pessoal da coordenação. Na verdade aquele pessoal que está lá, tem muitos que já era alguma coisa... foi drogado, tem problemas com alcoolismo, tem problemas de roubos... É nessa parte que a coordenação tem que ajudar a conscientizar aquelas pessoas para elas saírem daquele tipo de problema. A gente chama os coordenadores e vê realmente o que ele precisa e agiliza dentro do acampamento.

A gente trabalha muito forte sobre a parte da conscientização. Mas vai que eles caem, continuam com aquele tipo de processo... Fica complicado. Chega o caso até de expulsão por causa das outras famílias que já conscientizaram e tentaram mudar. Aí eles pressionam, ficam cobrando e fica complicado para gente. Tem vez que é o caso, não é um caso bom, não é legal, mas infelizmente chegamos a uma conclusão de expulsar do acampamento. Isso já aconteceu. Era problema de roubo. Nosso acampamento, no caso, estava mal visto. Chegava na cidade, o pessoal via a gente diferente, que era um bando de baderneiros, igual eu pensava antes. Entrava num supermercado, entrava o pessoal junto para conferir se não ia pegar alguma coisa. Foram três famílias expulsas por 
causa desse tipo de coisa, roubando em supermercado. Não teve outra maneira.

Mas para isso acontecer primeiro a gente faz o trabalho na coordenação, que senta e conversa. Daí vai para uma assembléia, chama todo o povo e o pessoal decide. A gente da coordenação não pode tomar uma decisão. É junto com o pessoal. A maioria decide.

Pedro ainda complementa dizendo como se sente quando se decide expulsar alguém do acampamento:

Dessas coisas que eu faço, não me sinto bem à vontade com o caso da expulsão do pessoal de acampamentos. São companheiros que estão há muito tempo com a gente. Naquela hora de decidir que ele vai ter que sair do acampamento, não me sinto muito bem...

Acho que o pessoal... até falei isso antes com os companheiros... que a gente procurasse outra maneira... Tipo, dar uma segunda, terceira chance... $\mathrm{Na}$ verdade, dá três chances, depois disso vai expulso. Acho que se prolongasse mais um pouco, mesmo para cinco... para tentar ver se conscientiza essa pessoa... Porque é triste ver um companheiro que está acampado, oito meses, colocar a bagagem em cima de um carro e sair... deixar a gente... Não gosto dessa parte. Acho que eles caem nesse tipo de problema porque não está bem consciente ainda. Acho que se descobrisse outra maneira de trabalhar com eles, pegava melhor. Também porque aqueles que saem não fica bem para gente... Tem uns que sai consciente do que fez. Tem deles que a gente não precisa nem fazer assembléia. Teve um caso no nosso acampamento... Ele apronta, sabe que aprontou e a terceira chance dele está esgotada, então ele simplesmente arruma as coisas e vai embora. Mas tem uns que não têm essa consciência aí e fica perseguindo a parte da coordenação e alguns dos acampados também.

Pedro não gosta de tirar ninguém do grupo. Parte da entrada no MST caracteriza a tentativa de sair da exclusão. Contudo, os casos de expulsão, mostram que esse não é um passo simples, pois cada grupo tem suas regras. Nas palavras do jovem Pedro percebe-se uma esperança nas pessoas, uma certeza de que todos podem mudar. A expulsão do acampamento é uma segunda exclusão, que resulta na volta da condição anterior. O paradoxo é que a "identidade" que seria inclusiva, e o é para muitos, se torna novamente excludente para aqueles que não se encaixam nas regras do grupo e seus padrões de 
comportamento. Dentre outros fatores, este paradoxo torna o estudo sobre o MST ainda mais rico, pois nele pudemos ver essas contradições e dualidades que fazem com que por vezes a luta contra a exclusão seja também excludente. Assim a comunidade faz imposições, as outras pessoas cobram um comportamento. Sobre isso Bauman também afirmou:

"A comunidade realmente existente" será diferente da de seus sonhos - mais semelhante ao seu contrário: aumentará seus temores e insegurança em vez de diluí-los a deixá-lo de lado. Exigirá vigilância vinte quatro horas por dia e à filiação diária [...] para manter os estranhos fora dos muros e para caçar os vira-casacas em seu meio próprio. E, num toque final de ironia, é só por essa belicosidade, gritaria e brandir de espadas que o sentimento de estar em uma comunidade, de ser uma comunidade pode ser mantido e impedido de desaparecer. O aconchego do lar deve ser buscado cotidianamente, na linha de frente ${ }^{272}$.

A promoção da segurança requer, para Bauman, um sacrificio da liberdade, pois caso contrário é como estar abandonado. Há nisso um paradoxo, porque segurança sem liberdade pode significar escravidão. Assim os membros de comunidades enfrentam diariamente esta contradição. Refletindo sobre essa questão Bauman completa:

A insegurança tende a transformar a multiculturalidade num "multicomunitarismo". Diferenças culturais profundas ou irrisórias, visiveis ou quase despercebidas, são usadas na frenética construção de muralhas defensivas e de plataformas de lançamento de mísseis. "Cultura" vira sinônimo de fortaleza sitiada, e numa fortaleza sitiada os habitantes têm que manifestar diariamente sua lealdade inquebrantável [...]. A "defesa da comunidade" tem que ter precedência sobre todos os outros compromissos. [...] Comunidades assim construídas viram expedientes que objetivam principalmente a perpetuação da divisão da separação e do isolamento ${ }^{273}$.

Como disse Hall, a identidade se define na diferença. Diferença que também foi um dos focos da pesquisa de Elias, definida

\footnotetext{
${ }^{272}$ BAUMAN, Op. Cit., 2003, p.22.

273 Idem, p.127.
} 
como os estabelecidos e os outsiders ${ }^{274}$ de uma comunidade. Ou seja, entre os de fora e os de dentro do grupo que como "iguais" sustentam e cobram uma determinada forma de agir nessa coletividade. O que está em jogo é o grau de identificação do indivíduo com o grupo. Quanto maior, menor a cobrança e maior a sustentação. De acordo com esse nível de cobrança o grupo pode se tornar excludente em sua radicalidade. Traçando um paralelo com estudos realizados com Foucault sobre a realidade iraniana, do crescimento do segmento xiita, nos anos 70, pode-se transportar algumas reflexões e justificativas:

Ela faz de milhares de descontentamentos, de ódios, de misérias, de desesperos, uma força. E faz de tudo isso uma força porque é uma forma de expressão, um modo de relações sociais, uma organização elementar fluida, amplamente aceita, uma maneira de estar junto, um modo de falar e de ouvir, algo que permite fazer-se ouvir pelos outros e querer com eles, simultaneamente a eles. 275

Pode-se aqui também correlacionar com alguns "guetos" urbanos (ou mesmo movimentos sociais) que buscam garantir coesão e estabilidade às pessoas que neles se agregam para fugir do estigma do fracasso, da derrota e da inferioridade social e que vão ser reconhecidos como pertencentes a uma detestada e abominada subclasse, por parte da opinião pública. Pois bem, são precisamente essas pessoas que, para parafrasear Hall, precisam de identidade no contexto excludente da globalização capitalista. As histórias de vida dessa tese a partir de suas subjetividades expressam esse caráter identitário.

Essas subjetividades devem ser respeitadas. O Movimento não pode homogeneizar os estilos de ser e muitas vezes isso acontece. Então a mulher acaba por reproduzir padrões (ter filhos e cuidar da casa e do marido) ou mesmo que contraditoriamente abrindo mão de sua feminilidade, deixando a vaidade de lado, vestindo sempre roupas "masculinizadas", sem cores ou complementos. Parece que essa nova

\footnotetext{
${ }^{274}$ ELIAS, N. e SCOTSON, J. L. Os estabelecidos e os outsiders. Sociologia das relações de poder a partir de uma pequena comunidade. Rio de Janeiro: Jorge Zahar Ed, 2000.

275 Téhéran: la foi cntre le Chah. Dits et écrits (éditions Quarto) II, 1978, n. 234, p.688. Citado por ARTIÈRES, P. Dizer a atualidade: o trabalho de diagnóstico em Michel Foucault. In: GROS, Op. Cit, p. 25.
} 
mulher não pode ser sexuada e o desejo tem que ser afastado. Talvez essas coisas tenham relação com a origem do Movimento, vinculado à igreja católica que tradicionalmente afastou a questão da sexualidade de sua homilia. Muito embora seja preciso criar relações pessoais diferenciadas, se o objetivo da ação dessas pessoas for criar um novo mundo em que se sintam confortáveis em seus papéis sociais.

Mas o que significa dizer que se quer um mundo novo, outro ou diferente? Significa no contexto do Movimento, mudar padrões, superar relações de dominação, sejam elas no mundo do trabalho, na família, na sociedade ou nas relações humanas, significa buscar a valorização do ser humano.

Outro ponto diz respeito ao trabalho e à questão do "espírito de sacrifício". A idéia do sacrifício é comumente associada a experiências religiosas do passado. Sua prática está relacionada ao tornar-se sagrado, pois o sacrificio tem como objetivo aproximar homens e mulheres comuns do desconhecido, do divino.

Marcel Mauss e Henri Hubert foram os primeiros pensadores a realizar um estudo que enfrentou a diversidade de fenômenos relacionados ao sacrifício, lido como um conjunto de ações dotadas de significado social. ${ }^{276}$ Claude Lévi-Strauss retoma o tema, pensando as estruturas dos sistemas sacrificiais como um elo de ligação com a divindade. ${ }^{277}$

Seguindo uma prática cristã, os integrantes desse movimento social têm no sacrifício uma forma de imaginar que serão recompensados de alguma maneira por viver um cotidiano duro. Os sem-terra caminham para um sagrado, em que utopicamente receberão como dádiva a "terra prometida" da reforma agrária.

Não se pode, contudo, pensar que todo trabalho dignifica o homem. Afinal há muitos que exigem um grande esforço. Claro que não se pensa ser possivel uma sociedade apenas de prazeres. A vida é

\footnotetext{
${ }^{276}$ MAUSS, M. \& HUBERT, H. Sobre o sacrifício. São Paulo: Ed. Cosac Naify, 2005.

${ }^{277}$ LÉVI-STRAUSS, C. O Pensamento selvagem. Rio de Janeiro: Zahar Ed., 1983.
} 
composta de várias facetas, nem todas boas. Mas nem por isso deve se fazer a apologia ao sacrificio e ao sofrimento.

Identidade camponesa no Brasil: essa é uma questão importante, o conceito deve ser reorganizado, refeito frente à realidade da diversidade cultural e regional do povo brasileiro. Além de pensar em processo de identificação e de constituição de uma identidade devemos pensar em identidades.

O perfil dos sem terra no Rio Grande do Sul, é bastante urbano, porque o pessoal do campo já foi quase todo assentado. Agora o perfil é do pessoal da cidade mesmo, que vive nas vilas, nas favelas. Daniel

Para pensar em identidades negociadas, exemplifica-se que a maior parte dos membros do MST, hoje, vive ou quer viver no campo, mas tem sua origem na cidade. Essa identidade então é uma identidade rural e urbana ao mesmo tempo.

Supõe-se também que é uma identidade mestiça, pois traz consigo as várias etnias que resultaram na formação do povo brasileiro. Evidentemente, há uma influência da cultura gaúcha, observada na presença do chimarrão nas reuniões dos coletivos, seja onde for que elas aconteçam. Isso é resultado de uma luta que teve um de seus inícios no sul do país, mas nessas mesmas reuniões a variedade de sotaques, tons de pele e vestimentas é notável, mostrando visivelmente o crescimento e a expansão desse movimento, e o engajamento de pessoas oriundas de diversos estados ocupando todos os postos da organização. São ao todo 23 estados, das cinco regiões brasileiras, em que o MST está organizado. Todos eles estão representados na estrutura orgânica da instituição por meio da participação nas discussões de pessoas deles oriundas.

Um exemplo concreto da participação dos estados e dos diferentes regionalismos envolvidos na criação identitária do MST são apontados no primeiro Censo da Reforma Agrária 278 de 1996 . Contudo o

\footnotetext{
${ }^{278}$ Um resumo das principais conclusões desse censo foi publicado em: Estudos Avançados, $n^{0} 31$. São Paulo: IEA, set/dez de 1997, pp. 7-36.
} 
último Censo Agropecuário, também realizado em 1996279, apontou o Nordeste como a região de maior concentração de cooperativas. Isso vai de encontro ao que vulgarmente pode-se relacionar ao Sul do Brasil. Claro que este dado não pode ser relacionado à ação do Movimento, apresento-o aqui com o objetivo de mostrar essas diferenças culturais e sociais que respondem a demandas de organizações locais.

De qualquer forma alguns preconceitos permanecem, como pode-se notar na narrativa de Daniel, que demonstra a dinâmica do processo interno:

E também porque tem as tuas crianças que tu conhece lá no estado, não convive com elas, mas conhece dos encontros que vai trabalhar na Ciranda ou nalgum outro negócio. Mas aqui é diferente, tem umas crianças de outra realidade diferente. Tem uns que mordem. Tem umas crianças que são muito dificil da gente trabalhar, que a gente não conhece.

Atualmente, como já foi dito, a identificação dos sem-terra extrapola a própria condição de não possuir terras, embora isso ainda seja algo importante. O que marca o início desse processo geralmente é a ida para um acampamento, como podemos perceber nas palavras de Adelir:

A ida para o acampamento foi uma decisão da minha mãe. Mas, na verdade, foi meio que uma contribuição nossa também. Como vivia no campo o sonho era sempre ter um pedaço de terra, para trabalhar, morar e construir alguma coisa. Então também contribuímos para que ela tivesse a coragem de ir. O fato é que o Movimento não era tão conhecido como hoje, era o início do Movimento. Faz 16, 17 anos.

O mesmo Movimento abriga pessoas de origens muito diversas. Essas pessoas, independente de suas histórias prévias, ou objetivos imediatos, são identificadas como "Sem Terra" e efetivamente, muitas vezes, assim se sentem. Ser "Sem Terra", para a identidade “oficial”, é mais do que não ter o próprio chão, abrangendo assim o

\footnotetext{
${ }^{279}$ O IBGE - Instituto Brasileiro de Geografia e Estatística - fará este ano o levantamento em 5 milhões e 700 mil estabelecimentos agropecuários de todos os municípios brasileiros.
} 
assentado e algumas vezes até mesmo o pequeno proprietário. Parte significativa do processo de formação dessa identidade central, como mostram as entrevistas, acontece nas marchas, nos cursos de formação e nas mobilizações que envolvem a luta pela conquista da terra ou por um ideal comum da conquista da cidadania e da reforma agrária. Parte desse processo de identificação principal é compartilhar de uma "revolta mística" e acreditar em uma sociedade transformada e melhor, que se crê, por meio da luta dos sujeitos, possivel no futuro. Assuntos esses que serão tratados com maior atenção no próximo capítulo.

Vários dos entrevistados contaram que a decisão de entrar no Movimento foi tomada por seus pais, como é o caso de Elizandra, Ana Paula, Adelir, entre outros. Essa entrada para eles foi o início de um processo de identificação. Antes disso, tinham pouca ou nenhuma ligação com o que ali (no acampamento, no assentamento, ou no próprio Movimento) era feito ou pensado. Nessas narrativas, são apontados outros momentos em que essas pessoas são chamadas à ação e percebem sua importância. Esses momentos são como uma confirmação da opção realizada por seus pais. Traça-se um novo projeto familiar. Essa confirmação é um momento sempre narrado com muito detalhe e emoção, nos levando a refletir sobre sua importância para a formação desse sujeito que passa a pensar e agir de forma diferente da anterior. É o momento em que passa a se sentir parte do grupo, não por uma opção alheia, mas por decisão própria.

$\mathrm{Na}$ história de vida de Elizandra podemos até mesmo ver um certo ressentimento em relação à opção de sua mãe. Ela chega a afirmar "Foi a segunda vez que a minha mãe deixou tudo, abandonou tudo e foi." Abandonou a família e os filhos...

A entrevista de Ana Paula caracteriza uma experiência de vida prévia fora do Movimento que, embora pobre, possibilitou algumas inserções (educação, namoro e emprego). Ana Paula parece resistir a mudanças e não foi diferente quando foi morar com seu pai em um assentamento. A entrada no MST não era algo pensado por ela. Não gostava dali, não conhecia ninguém, estava longe das relações que com 
tanta dificuldade conseguiu construir na cidade. Negava sua presença ali, ficando horas no telefone com os "de fora".

A sensação de ser importante para o Movimento, ser útil para as pessoas e de estar atuando no Setor de Educação - ou outros setores, no caso dos demais narradores - re-significa sua jornada. Ana Paula, hoje, é "mais importante" para ela mesma, o que muda a maneira como se percebe, criando para si, uma nova identidade.

Assim, pode-se refletir que em maior ou menor grau, a entrada no Movimento transforma as pessoas que dele participam. Alguns passam mesmo a "existir", outros alteram seus comportamentos e hábitos e adotam uma nova identidade. Como é o caso de Aquiles, que narrou:

Você me pergunta sobre minha vida antes de entrar no MST... Eu não tive vida fora do Movimento. Tudo que sou é graças ao Movimento. Aprendi tudo aqui. Antes... não tem como contar. Entrei com sete anos no MST. Tudo que fiz... Todos meus estudos... Não fiz nada fora do MST. (...) Hoje, se o povo perguntar: "Quer uma vida fora do Movimento Sem Terra?" Vou responder assim: "Que vida fora do Movimento Sem Terra? Essa foi a vida que nós construímos!" Quando constrói, não pode abandonar o que construiu.

Evidentemente que Aquiles viveu sua primeira infância antes de sua entrada no Movimento Sem Terra, mas escolheu não falar sobre isso. Para ele o que importa é a vida depois, quando pode estudar, aprender e atuar. Sentir-se acolhido é um dos passos desse processo de identificação, seja na primeira reunião ou nas festas do acampamento/assentamento. O que importa é a forma mais humanizada com que as pessoas se tratam, o respeito e o carinho demosntrados. Assim, quando do primeiro contato esses narradores contam como se sentiram acolhidos e repete-se em várias histórias a idéia de que "não estava acostumado com aquilo", ou ainda, "foi muito 
diferente para mim", de forma a concluir: "me senti bem ali". Elizandra conta:

Uma coisa que me lembro bem era o cuidado com a gente, com o ser humano em si. "Seja bem vindo ao assentamento", o jeito na festa de apresentar a gente. "Ó, essas aqui são as filhas da professora Cida", "Vão vir morar aqui no assentamento junto com a gente". A gente não era acostumado com isso. Minha mãe ia tomar chimarrão na casa da senhora vizinha. Pessoal muito humilde também.

Em suas histórias de vida os sem-terra mostram suas formas simultaneamente individuais e coletivas de comunicar e de agir. Trazem à tona novas percepções, novos conceitos, novas histórias, novas questões que eclodem na vida de pessoas que antes estavam à margem da sociedade. Para os trabalhadores rurais, todo esse universo inédito, rico e conflituoso traz consigo a novidade da consciência de si mesmo e do mundo, também criando condições extraordinárias para se libertarem de várias formas de opressão que perpassam as formas de comunicação existentes e que obliteram a troca e a transmissão de experiências como as suas.

A partir das reflexões de Giorgio Agamben sobre a noção de experiência, quer-se debater o papel atribuído aos narradores quanto à não destruição da experiência. Nesse sentido, busca-se compreender como as narrativas de histórias de vida - elaboradas a partir de um processo de trabalho ligado à história oral - inserem suas práticas cotidianas, tramando possiveis sentidos e significados das memórias, das identidades e das subjetividades em permanente (des)construção no cotidiano da história.

Os processos de identificação mediados pela participação das pessoas no MST estimulam a formação de uma identidade coletiva, a qual se chama nessa tese de "central" ou "oficial". Como as pessoas se vêem, em plena negociação entre suas muitas necessidades e suas múltiplas identidades, são jogos de espelhos que levam em conta a emergências das subjetividades envolvidas. 


\section{Participação e atuação:}

\section{processos de consolidação identitária}

Digo que o sangue do MST corre na minha veia. E quando estou nas manifestações me sinto... enfeitiçada! Me sinto gente! Quando estou no Movimento, me sinto importante! Cada um de nós aqui é importante! O calor humano que tem entre nós!... Wanderléia

A constituição de uma identidade pensada pelo Movimento Sem Terra muitas vezes faz parte de estratégias elaboradas pelas lideranças. As mobilizações são momentos em que dois dos objetivos do MST podem ser trabalhados conjuntamente: as reivindicações e a agremiação (ou como os próprios sem-terra chamam, a massificação). De qualquer forma, os envolvimentos acontecem ou se estreitam ao se participar de uma ação coletiva concreta. Dentre os vários tipos de mobilizações que são organizadas, destacam-se, nas narrativas, a formação de acampamentos, as ocupações, os despejos, os cursos de formação, as místicas e as marchas como momentos centrais para a consolidação do conjunto de referências a que se remete a uma identidade "Sem Terra".

Manifestações são exemplos de ações que promovem uma identidade oficial, que se pretende coesa, linear e homogênea. Escolheu-se o verbo pretende, pois:

... toda homogeneidade deve ser "pinçada" de uma massa confusa e variada por via de seleção, separação e exclusão; toda unidade precisa ser construida; o acordo "artificial produzido" é a única forma disponível de unidade. O entendimento comum só pode ser uma realização, alcançada (se for) ao fim de longa e tortuosa argumentação e persuasão, e em competição com um número indefinido de outras potencialidades - todas atraindo a atenção e cada uma delas prometendo uma variedade melhor (...) de tarefas e soluções para os problemas da vida. 280

\footnotetext{
${ }^{280}$ BAUMAN, Op. Cit, 2003, p.19.
} 
$\mathrm{Na}$ busca desse "entendimento comum" e se utilizando de uma "longa e tortuosa argumentação e persuasão" é que se organizam mobilizações como reuniões, encontros ou cursos de formação, ministrados com apoio de materiais didáticos, boletins, livros e textos elaborados com essa finalidade.

Além dessas publicações de circulação interna, há outras. O Movimento mantém uma página na internet, um informativo eletrônico "Boletim dos Sem Terra", o "Jornal Sem Terra"281, a revista "Sem Terra"282 e o programa "Vozes da Terra"283. Essas publicações podem ser assinadas e são distribuídas entre os assentamentos do Distrito Federal e dos 22 estados onde o MST está organizado.

Conjuntamente, um grande trabalho de base é realizado pelo setor de Frente de Massa. Nas palavras de Adelir:

Ainda temos dificuldades, no Movimento, de fazer esse trabalho, mas sempre é feito. Acho que no momento que nós vamos fazer a reunião para que a família venha para o acampamento, participa gente que não vai vir para o acampamento. Mas mesmo que não venha, de uma certa forma, vai ficar conhecendo o Movimento. Alguma coisa do Movimento fica, vai ter a referência de um amigo que foi para o acampamento. O mesmo acontece com o trabalho com estudantes.

Com isso Adelir defende a validade do trabalho da Frente de Massa, independentemente dele agregar ou não pessoas novas. Parte da função do trabalho é, para esses militantes, divulgar e mudar a

\footnotetext{
${ }^{281}$ O Jornal Sem Terra é uma publicação mensal, “voltada, principalmente, para seus militantes. Surgiu antes da fundação oficial do MST e, desde então, tem sido um instrumento de formação e informação para o Movimento e para a sociedade. Com tiragem de 20 mil exemplares, o JST procura agregar forças na luta pela Reforma Agrária e por um projeto popular para o Brasil”". http://www.mst.org.br/mst/jornal_pagina.php?ed=37\&cd=736, acessado em 07/02/07. ${ }^{282}$ A revista Sem Terra é uma publicação bimestral, editada há oito anos pelo MST.

${ }^{283}$ O programa "Vozes da Terra" foi criado em julho de 2000 com a proposta de apresentar a "visão de mundo do Movimento Sem Terra e tratar de temas relacionados à luta pela terra pelo rádio. Por meio de parcerias com a Universidade Católica de Santos (Unisantos) e com o Departamento de Jornalismo da Faculdade da Comunicação e Filosofia da Pontifícia Universidade Católica (PUC-SP), junto com a participação de estudantes universitários, foram produzidos 20 CDs e, no total, cerca de 80 programas (disponíveis na internet). Em julho de 2005, passamos a produzir programas semanais, de três minutos em média, distribuídos pela internet.” http://www.mst.org.br/mst/vozes_pagina.php?cd=1303, acessado em 07/02/07.
} 
imagem do MST. Mesmo sabendo das limitações e do alcance da ação dos membros desse setor Adelir continua:

Acreditamos que teria que trabalhar melhor essas questões da reforma agrária e do conjunto com a sociedade como um todo: a Igreja, os estudantes, o desempregado. Fazer com que cada um construa um pouco da história.

Elizandra complementa essa idéia quando diz:

Isso mal ou bem, porque não é fácil o coletivo. A gente sempre está ampliando, massificando, mas a gente nunca consegue, pois sempre têm uns indo, outros vindo.

Ronaldo contou em sua entrevista detalhes de como se organiza esse trabalho de base e como se entra em contato com as pessoas.

Antes de nós ir fazer um trabalho na Frente de Massa, passa um dia de estudo, conhecendo a realidade da cidade. Tem apoio na cidade e nós vamos lá passar dois, três meses organizando as famílias dos bairros carentes, convidando, porta a porta, para uma reunião. Trabalhamos mais com associações e centro comunitário. Tentamos organizar as famílias, que foram cadastradas pelo correio antigamente, por aquela propaganda que o Fernando Henrique Cardoso fez. Muitas pessoas têm esperança daquilo. De conseguir junto do Banco da Terra um crédito fundiário. A gente vai lá tentar mostrar a realidade que não é aquela. Mostrar a realidade da vida das pessoas! A nossa atividade é ir para as cidades carentes com o objetivo de formar acampamento.

Evidentemente, a certeza em sua verdade é característica de quem toma posição de liderança dentro de um grupo. E não é exclusividade da narrativa de Ronaldo. Ela é compartilhada em versos como mostrou Seu Luiz:

"Com a verdade na frente e a cara não esconder, e não deixo nada encoberto porque vou no caminho certo com o MST."

Acreditar nessa realidade dá à fala de Ronaldo e de Seu Luiz um tom quase missionário. Esses homens são representantes do 
Movimento e por isso carregam essa "verdade". No caso específico de Ronaldo, seu setor é o responsável por trazer pessoas novas, um dos trabalhos mais dificeis e ao mesmo tempo importantes para a sobrevivência e renovação da organização. Esse primeiro contato deve ser reforçado por trabalhos futuros com essas pessoas. Normalmente, em uma reunião prepara-se uma ocupação para se formar um acampamento. Quando ocorre o despejo, esse acampamento é transferido para outra área e ali pode ficar por muitos anos. Mas a ocupação só ocorre quando um número razoável de famílias é mobilizado e concorda em participar.

Nem todos os mobilizados pelo trabalho de base passam a se sentir parte do Movimento. Quando isso acontece é um processo. Elizandra contou sobre sua primeira atividade no Movimento, um encontro de jovens, tudo ali era interessante e novo. É relevante como ela mesma conta: "comprei boné, já queria colocar. Estava naquele momento me apaixonando pelo Movimento!” É fato que não estava apaixonada ainda, mas se apaixonando, ou seja, em pleno processo de identificação. Ela mesma complementou: "Eu sei que não queria mais parar de participar, depois do encontro."

De forma geral, pode-se identificar nas narrativas alguns dos momentos em que essa identidade se manifesta com uma força maior, ou o instante em que o narrador se percebeu identificado com o Movimento.

Nesse sentido, cita-se uma entrevista, que não foi apresentada na integra, para que esse trabalho não se tornasse muito grande. Este trecho é bastante representativo desse momento em que a pessoa se sensibiliza e se identifica com o grupo. Rosângela se definiu em sua entrevista como uma ex-burguesa, pois antes de entrar no MST, vivia na cidade, não trabalhava e tinha boas condições de vida. Entretanto, seu marido resolveu entrar no Movimento e ela o acompanhou. Para ela:

A coisa mais importante que aconteceu dentro do Movimento, foi o dia do nosso despejo. Fazia um mês que nós estávamos acampados, daí nós tivemos o despejo. Hoje em dia, para mim 
é normal, mas a primeira vez... quando eu olhei dentro do ginásio... não sei se dá para identificar a sensação, principalmente, vindo de mim, que nunca tinha visto isso na minha vida! Eu e meu marido dormimos no carro, e o pessoal dormiu dentro do ginásio... De madrugada me deu vontade de ir no banheiro. Eu fui para o ginásio. Quando eu entrei, que eu vi aqueles colchões tudo no chão, e todo mundo deitado, as crianças... Parei, fiquei olhando. Comecei a chorar!... Foi uma emoção tão grande ver aquilo! Naquela hora eu falei: "acho que a gente não deve abaixar a cabeça. Tem que erguer a cabeça e batalhar e vencer".

$\mathrm{Na}$ verdade, naquele momento eu tive vontade de ter um braço bem grande para abraçar todo mundo. Lá é quente, mas estava uma noite fria naquele dia, chovendo. Estava vendo o incômodo daquelas pessoas. Tinha uma criança que tinha sete dias, a mãe, nova também, com 16 anos... dormindo no chão... A vontade que eu tinha é de abraçar todo mundo e acolher. Mas é uma coisa que não podia fazer. É uma sensação que não tem como descrever.

Evidentemente, momentos como esse, vivido por Rosângela, marcam o início de uma relação diferenciada, mas essa relação deve continuar e se confirmar em outros atos num contínuo movimento entre sujeito e coletividade. Relações essas que se interpenetram fazendo com que coletivo e sujeito sejam conjuntos com uma área maior ou menor de intersecção.

Esses momentos de identificação profunda se dão de diferentes formas para cada um. Por mais que o MST se organize para sensibilizar seus membros e criar condições para uma "conversão" ocorrer, como ela não é algo formal, pré-definido, determinado, ela depende das subjetividades de cada um.

Isso porque, como Denzin discutiu em seus estudos, entender como os indivíduos identificam os "turning points" de suas vidas é fundamental para que o pesquisador possa interpretar suas histórias. Em seu livro Interpretative Biography, ele apresenta o conceito de "epiphanies," que pode significar: o momento que muda sua vida; o momento que vem sendo construído quando o indivíduo percebe que a mudança é irrevogável; ou ainda em suas palavras a "minor epiphany", 
um simbolo que trás um "insight" para compreender um evento e dar a ele significado. ${ }^{284}$

De qualquer forma o que se destaca é o componente emoção, tanto que Daniel chega a afirmar:

Acho que não tem um momento que eu seja mais sem-terra... $\mathrm{Eu}$ acho que tem alguns momentos que arrepiam. Por exemplo, numa ocupação, numa marcha... no começo da marcha aqui. A gente fica mais emocionado que em outros momentos. Participei acho que de umas quatro ocupações.

Nesse sentido, destacam-se as místicas, que se fazem presentes no cotidiano dessas pessoas, como forma de organizar a comunidade em torno de elos identitários. No entanto, as místicas são argumentos pouco objetivos, mexem com as emoções, acionam relações muito particulares, estabelecidas de acordo com a experiência de cada sujeito. Como definiu Boff, "não é o limite da razão, mas o ilimitado da razão". ${ }^{285}$ Seu resultado é menos previsível e muitas vezes pode organizar identidades diversas, tornando esse quadro de possibilidades identitárias mais cheio de cores. As místicas podem sensibilizar para o questionamento de relações de gênero e raça, por exemplo, fomentando um posterior debate/embate.

De forma geral, quando se fala de mobilizações e de místicas é inevitável trazer para essa discussão uma reflexão sobre ritual. Esses momentos podem ser comparados a rituais que caracterizam uma passagem de um tipo ou estilo de vida para outro. Segundo Van Gennep, autor que, no início do século XX, dedicou-se ao estudo dos rituais - os ritos de passagem são momentos de mudança, de transição de pessoas ou grupos sociais para uma nova etapa da vida, para um novo espaço social, ou, no caso dos sem-terra, ambos. A obra de Van Gennep influenciou vários pesquisadores, entre eles o antropólogo Victor Turner. "Turner concebe os eventos conflitivos enquanto 'drama social' (os rituais, aqui, servem basicamente para resolver conflitos,

\footnotetext{
${ }^{284}$ DENZIN, Norman K. Interpretative Biography. Thousand Oaks, CA: Sage, 1989.

${ }^{285}$ BOFF, L., Alimentar a nossa mística, mimeo, 2001, citado por SAMPAIO, P. A. Op. Cit.
} 
diminuir rivalidades). Victor Turner analisou os rituais de iniciação..."286 Os estudos sobre rituais continuaram e elos entre ritos de iniciação e de passagem foram sendo pensados.

Podemos dizer, assim como Andràs Zempléni, que o protótipo dos ritos de passagem são os ritos de iniciação: como os ritos de passagem, os ritos de iniciação marcam a transição de um status social para outro (morte e renascimento simbólicos). A iniciação é, portanto, a "forma sintética dos ritos de passagem, por meio dos quais ela opera". Mas a iniciação é mais do que simplesmente um rito de transição, ela é um rito de formação. Esta formação vai diferenciar os participantes ou o círculo dos neófitos dos "de fora", daqueles exatamente nãoiniciados. Numerosas iniciações contam com ritos de inscrição nos corpos de marcas, signos visíveis da formação e transformação de nova identidade (escarificações, circuncisões, modificação do formato dos dentes, perfurações no nariz ou lábios etc.). ${ }^{287}$

De qualquer forma, mesmo com muitas definições apresentadas, como marcou a antropóloga Mariza Peirano:

A compreensão do que é ritual não pode ser antecipada. Ela precisa ser etnográfica, isto é, compreendida pelo pesquisador em campo junto ao grupo que ele observa. Esta postura deriva da noção de que a antropologia sempre deu (ou teve como intenção dar) razão e voz aos nativos, levando em consideração a perspectiva de um "outro" diferente, de grupos que não pensam e agem como nós. Explico em relação aos rituais: em todas as sociedades existem eventos que são considerados especiais. ${ }^{288}$

Depois de marcada essa posição, em defesa do trabalho de campo, a autora forneceu sua "definição operativa", inicialmente formulada por outro antropólogo - Stanley Tambiah - dedicado aos estudos contemporâneos sobre rituais.

O ritual é um sistema cultural de comunicação simbólica. Ele é constituído de seqüências ordenadas e padronizadas de palavras e atos, em geral expressos por múltiplos meios. Estas seqüências têm conteúdo e arranjos caracterizados por graus variados de formalidade (convencionalidade), estereotipia

\footnotetext{
${ }^{286}$ RODOLPHO, Adriane Luisa. Rituais, ritos de passagem e de iniciação: uma revisão da bibliografia antropológica. In: Estudos Teológicos, v. 44, n. 2, p. 138-146, 2004, p. 143. ${ }^{287}$ Idem, p. $144 / 5$.

${ }^{288}$ PEIRANO, M. Riruais ontem e hoje. Rio de Janeiro: Jorge Zahar Editor, 2003, p.9.
} 
(rigidez), condensação (fusão) e redundância (repetição). A ação ritual nos seus traços constitutivos pode ser vista como "performativa" em três sentidos; 1) no sentido pelo qual dizer é também fazer alguma coisa como um ato convencional [como quando se diz "sim" à pergunta do padre em um casamento]; 2) no sentido pelo qual os participantes experimentam intensamente uma performance que utiliza vários meios de comunicação [um exemplo seria o nosso carnaval] e 3), finalmente, no sentido de valores sendo inferidos e criados pelos atores durante a performance [por exemplo, quando identificamos como "Brasil" o time de futebol campeão do mundo]. 289

No caso desta pesquisa, pode-se fazer um paralelo das reflexões sobre o trabalho etnográfico com a história oral e assim, destacar que para essa comunidade estudada esses momentos de encontro e mobilizações são ritualísticos, ou seja, a primeira reunião com membros do MST, as marchas e as ocupações podem ser caracterizadas como rituais de passagem. Esses momentos são lembrados e destacados, ao lado de eventos da vida particular como o nascimento de um filho ou a morte de um familiar.

Supõe-se que o convite para participar dessas reuniões é o início dos procedimentos desse ritual. A mudança para uma nova etapa da vida pode ser percebida em falas de narradores que, como Wanderléia, não se sentiam "gente", sujeitos de suas histórias e dão sentido à sua vida a partir da entrada no MST. Esses rituais transmitem valores e ajudam a forjar identidades.

Ao contar sua história, Wanderléia fala da primeira reunião da qual participou. Não foi fácil para ela ir até lá, como contou, ao chegar foi "conhecendo várias pessoas" e se sentiu importante. Esse foi seu primeiro contato com o MST. É nesse instante que foi convidada a fazer parte do grupo. Essa é uma das passagens em que parece acontecer o que Leach conta ter acontecido com ele mesmo em seu texto sobre "Como nasce um cavaleiro britânico", em que retoma o conceito de Van Gennep de "rito de passagem".

\footnotetext{
${ }^{289}$ Idem, p.11.
} 
O iniciante, tendo sido "morto" no seu antigo papel, precisa ser "trazido de volta à vida" em seu novo papel. Para que isso possa ser realizado, o poder da Soberania precisa fluir através da Rainha para o iniciado. $\mathrm{E}$ isso se consegue através do contato físico com o corpo da Rainha. A accolade moderna é, na verdade, o aperto de mãos! 290

Wanderléia, assim como outros, foi “agregada” ao MST, pelos apertos de mão que deu na noite da reunião. A entrada no MST é acompanhada pela organização de uma ocupação, responsável por mudar o status social dela e de sua familia.

Assim a partipação, seja ela em uma reunião, uma manifestação, uma ocupação ou qualquer outro momento de atuação junto ao grupo, é fator que ajuda a consolidar uma identidade. O processo de identificação tem, portanto, na atuação das pessoas um passo importante para que se possa chegar à formação de uma identidade cada vez mais relacionada ao Movimento dos Trabalhadores Rurais Sem Terra.

\section{Simbologia sem-terra}

Nas mobilizações há uma série de símbolos. Uns particulares do MST, outros gerais, do Brasil. É importante notar o respeito que o Movimento tem pelos símbolos nacionais. Em especial pela bandeira brasileira. Sampaio lembra a aparente contradição gerada pela apropriação e uso desse elemento.

Não há reunião, grande ou pequena, em que a bandeira brasileira não penda de algum lugar saliente. O curioso é que a bandeira brasileira é um símbolo do poder da elite que proclamou a República, no século XIX. Como o símbolo do opressor pode pontificar em uma assembléia de militantes socialistas? A explicação é simples: no decurso da história, um povo despolitizado apropriou-se do símbolo da elite, sem perceber seu significado e atribuindo-lhe outro: o da Nação que querem construir. Não foi assim que aconteceu com o símbolo romano da morte execrável, transformado pelos cristãos no símbolo de uma vida gloriosa?291

\footnotetext{
${ }^{290}$ LEACH, E. Once a knight is quite enough (sic): Como nasce um cavaleiro britânico. Mana, Abr. 2000, vol 6, n.1, p. 48.

${ }^{291}$ SAMPAIO, P. A. Op. Cit.
} 
O Movimento, portanto, apropriou-se de símbolos como a bandeira nacional, mas criou outros, para compor suas referências. Alguns já são do conhecimento geral. Quando se fala em sem-terra, a relação é quase imediata: imagina-se uma pessoa vestida de vermelho com seu boné, empunhando sua bandeira, também vermelha. É importante lembrar que existem vários movimentos sociais no campo e na cidade, a grande maioria utiliza o mapa do Brasil em seu emblema e o vermelho como cor predominante em suas bandeiras. Quase todos usam bonés, camisetas, chinelos, foices, pás e outros instrumentos de trabalho em suas manifestações.

Como exemplo apresenta-se imagens dos emblemas do MST e de outros movimentos sociais ${ }^{292}$, cujas particularidades não estão sendo analisadas.

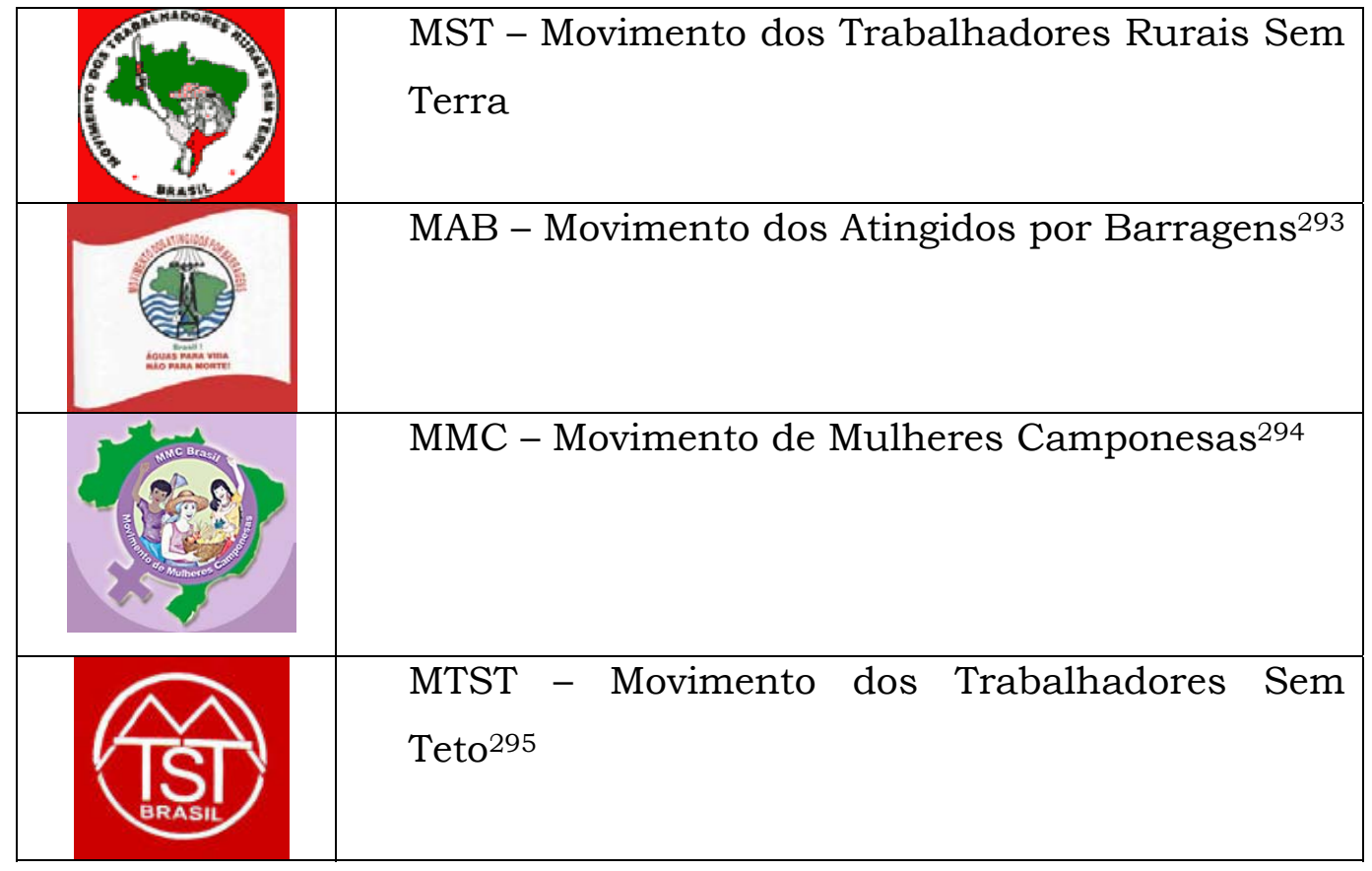

Esses emblemas, presentes nos bonés, bandeiras e camisetas, são identificadores. O uso desses simbolos foi uma construção e hoje se

\footnotetext{
${ }^{292}$ Há ainda outros movimentos sociais rurais como MPA - Movimento dos Pequenos Agricultores, Mast ou Master - Movimento dos Agricultores Sem Terra, PJR - Pastoral da Juventude Rural, que não estão presentes nessa lista pois não foi possível encontrar seus símbolos.

${ }^{293}$ Imagem retirada do site, http://www.mabnacional.org.br/atuacao.html, acessado em 15/03/07.

${ }^{294}$ Imagem retirada do site http://www.mmcbrasil.com.br/index.html, acessado em 15/03/07.

295 http://www.mtst.info/, acessado em 15/03/07.
} 
caracteriza como um elemento de união e identidade sem-terra. Segundo Branford e Rocha "para milhares, o boné não é importante porque representa o socialismo - para muitos um conceito vazio -, mas porque identifica a pessoa que o usa como um sem-terra"296. Assim, se cria um "espírito de corpo". O boné e a bandeira passam a ser uma marca de sua presença. Estratégia semelhante à descrita por Hobsbawm sobre a formação da classe operária inglesa, com a adoção de seus "bonés chatos, de bico"297.

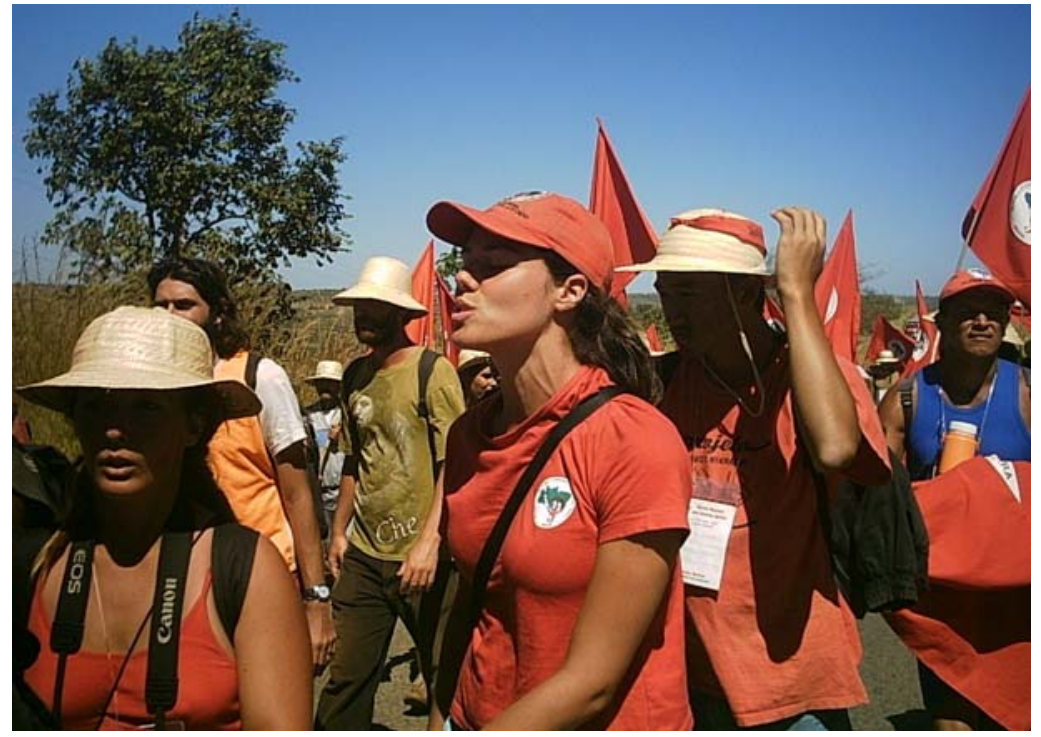

Marchantes suas camisetas, bonés e bandeiras a caminho de Brasília, maio/05.

Esses emblemas estão presentes nos palcos das ações de luta, mas são também cotidianamente significados nas místicas. Nessas ocasiões as bandeiras e bonés ganham um sentido subjetivo, quase sentimental. Representam o trabalho, mas, mais que isso, representam também a memória dos que morreram, os que conquistaram suas terras e os que continuam lutando.

Quando Ana Paula descreve como foi seu primeiro contato com o Movimento pode-se refletir sobre a importância dos símbolos para o processo de identificação.

\footnotetext{
${ }^{296}$ BRANFORD e ROCHA. Op. cit., p 328.

${ }^{297}$ HOBSBAWM, E. Worlds of labour: futher studies in the history of labor. London, Weidenfeld and Nicolson, 1984, p.199, citado por BRANFORD e ROCHA, Op. Cit., p.330.
} 
Nesse momento ele entrou no MST. Mas eu nem sabia o que era. Às vezes ia para casa na Bomba e ele estava lá. Ele falava e eu sempre dizia: "Ah papai, parece que tá é doido". "Ficar com esse povo, que não tem nada o que fazer!". Ele participou de um ato em São Luiz e trouxe umas fotos dos companheiros que estavam nesse ato. Todo mundo vestido, com a blusa do MST, blusa branca e as letras em vermelho M S T. Eu achei muito bonito. Todo mundo com bandeiras, debaixo de uma árvore. Era assim... umas trinta pessoas. Achei muito bonito e eu comecei a perguntar para ele como que era. Ele sempre foi trancadão, mas falou: "Isso daí é muito organizado, Ana Paula, é muito bonito o trabalho que eles fazem".

Ao achar "muito bonito", Ana Paula começava a desfazer a imagem do "povo que não tem nada o que fazer", substituí-la por algo diferente, e mais positivo. A idéia de organização, enfatizada por seu pai, reforçou essa aproximação. Nesse momento, não se pode falar de uma identidade sem-terra para Ana Paula, mas pode-se dizer que por meio dessa aproximação, inicia-se um processo de identificação.

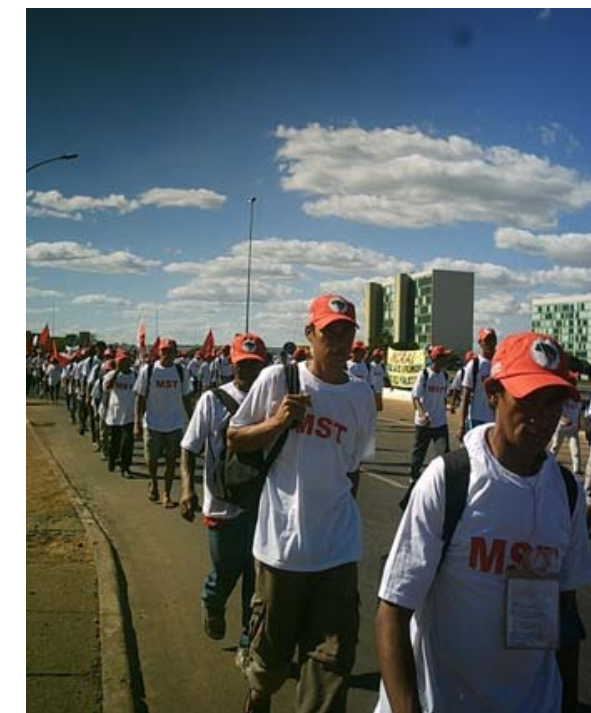

Os sem-terra com bonés e camisetas novas (brancas com as letras em vermelho M S T), entregues pelo Movimento, para a caminhada na Esplanada dos Ministérios, Brasília-DF.

Essa aproximação, que caracteriza uma mudança de visão, ora aparece mediada pela entrada no MST do pai ou da mãe, como no caso de jovens como Ana Paula e Elizandra, ora pelo desafio da precariedade da vida dada aos filhos, como é o caso de Wanderléia. Há ainda os casos em que essa aproximação é resultado de conquistas concretas, como explicou Seu Luiz, justificando conjuntamente sua entrada no MST e a participação nas marchas.

Quando foi em 1996, meu filho tinha acampado e já estava assentado. Eu vi que o MST deu condição da gente pegar uma terra para melhorar de vida. Então, me enfiei numa marcha. 
Outro elemento agregador pode ser percebido no uso de lemas e expressões do Movimento que acabaram incorporados no discurso desses narradores. Aquilo que podia parecer um slogam vazio ganha força e peso, quando re-significado em sua experiência concreta de vida e de luta dessas pessoas. Wanderléia, em sua entrevista, cita o lema "Não queremos guerra, queremos terra!" falado inúmeras vezes nas fileiras da marcha, e completa "queremos vida digna" explicando o quê, para ela, é ter uma vida digna. Ou seja, o grito de guerra tem função prática. Por ter sido incorporado, faz sentido e dá força para o caminhar.

Importante notar que há ainda outros símbolos, como os mártires ou heróis dessa luta, que se fazem presentes nas caminhadas e nos diversos encontros do MST. Sampaio explica:

As celebrações são sempre enquadradas pelos grandes retratos de lutadores do povo. Aqui explode o sincretismo da mística dos sem-terra: Marighela, o lider comunista guerrilheiro, figura ao lado de Paulo Freire, o revolucionário pedagogo católico; Rosa de Luxemburgo junto com Madre Cristina, freira católica; Florestan Fernandes, sofisticado intelectual marxista, vizinho ao Padre Josimo, cura do sertão, assassinado pelos jagunços do latifúndio; Carlos Marx ao lado de Jesus Cristo.

Quem se espanta com a mescla, na verdade, conhece muito pouco da mentalidade do povo brasileiro e nem parece também estar atento as verdadeiras dimensões do humanismo socialista. 298

Esses homens e mulheres que estampam cartazes são símbolos porque exemplos de vida e de luta. Toda essa simbologia semterra "identifica o grupo e o vincula ao passado, mas, ao mesmo tempo o projeta no futuro, com a imagem de um Brasil justo”. ${ }^{299}$ Dessa forma a presença de todos esses símbolos nas manifestações do Movimento dá força aos que estão marchando para a construção desse país melhor.

\footnotetext{
${ }^{298}$ SAMPAIO, P. A. Op. Cit.

${ }^{299}$ Idem.
} 
Paradoxos cotidianos de uma luta

Sem dúvida é na busca por inclusão, por uma vida melhor, que essas pessoas marcham, acampam e se mobilizam. Mas estar no MST é partilhar de um cotidiano cheio de contradições e provações.

Pode-se dizer que é bom estar no acampamento, assentamento, na marcha, pois nesses contextos as pessoas tornam-se "iguais", estão em meio de seus pares. "Lá" esses sujeitos deixam de ser sozinhos e passam a ser grupo. Fora de lá são "minorias", mesmo representando a maior parcela da população, ou seja, são vidas sem valor político, social e econômico e que, portanto, podem ser ignoradas, pois são "refugo humano"300, "sem lugar e sem função"301.

Essas pessoas, durante o processo de luta, vivem em lugares especialmente "planejados" para elas. Os acampamentos são estruturas transitórias que se formam, onde mora, por um tempo indeterminado, um número flutuante de integrantes. Entretanto, o que há em comum a todos eles é a falta de infra-estrutura. Esses locais não possuem água, energia ou instalações sanitárias. Acampamentos são ocupações de pequenos espaços, que podem estabelecer-se em um pedaço de terra a ser desapropriada ou com a permissão do proprietário, ao longo das rodovias - geralmente públicas - ou mesmo nas cidades, como forma de pressão mais efetiva. Seja onde for, os acampamentos, parafraseando Bauman, abrigam pessoas que podem ser comparadas a refugiados em seu próprio país.

Tornar-se "um refugiado" significa perder "os meios sobre os quais assenta a existência social, ou seja, um conjunto de coisas e pessoas comuns portadoras de significados - terra, casa, aldeia, cidade, posses, empregos e outros marcos divisórios cotidianos. Essas criaturas à deriva e à espera não têm nada senão sua "vida crua", cuja continuação depende da ajuda humanitária”. ${ }^{302}$

\footnotetext{
${ }^{300}$ BAUMAN, Z. Vidas desperdiçadas. Rio de Janeiro, Jorge Zahar Ed., 2005, p. 88.

${ }^{301}$ Idem, p. 97.

${ }^{302}$ Idem, ibidem, citando AGIER, Michael. Aux bourds du monde, lês refugies. Flammarion, 2002, p.55/6.
} 
Tais "refugiados" brasileiros perderam seus "marcos divisórios cotidianos", de onde extraíam suas identidades e buscam novas possibilidades de construção. Sem poder contar com o apoio do Estado, buscam asilo em tais acampamentos, e passam a viver ali uma dualidade, pois permanecem na exclusão - sem terra, sem casa, sem emprego, sem bens - mas começam a sentir a inclusão - ali formam uma nova "aldeia" e passam a viver em comunidade.

Assim o acampamento ao lado de encontros, cursos e da própria marcha, pode ser visto como um momento de formação, que ajuda a consolidar uma identidade. Como contou Adelir:

... a formação se dá também no acampamento. Desde que se começa o acampamento, além de ter o barraco e de estar lutando pelo teu pedaço de terra, está participando da reunião de como organizar a infra-estrutura: a segurança, a alimentação... Então isso também faz parte da formação porque ela exige que a pessoa não passe a pensar só no "eu", mas a pensar e discutir o "nosso". E tem momentos lá dentro do acampamento de estudos mais teóricos, juntando com a prática também do dia-a-dia. Tem uma coordenação que vê o todo do acampamento. Tem encontros da regional e da estadual. E tem vários cursos de formação política e técnica, que vai pessoas dos acampamentos e dos assentamentos.

Ao mesmo tempo em que foi proposto no capítulo "Exclusão: uma história anterior ao MST", uma leitura da experiência de exclusão desses sujeitos como traumática, pode-se agora pensar o caminho inverso. A inclusão, mesmo que numa situação de acampado, é algo prazeroso. Essas ações coletivas são momentos importantes, que envolvem tensão, mas nas quais amizades são feitas, namoros começam... Sempre junto a essas grandes mobilizações são realizadas noites culturais, festas, bailes, ocasiões cheias de músicas, em que as pessoas se divertem.

Tudo é celebrado, como contou Elizandra, que conheceu o acampamento de sua mãe em uma noite cultural e mais tarde voltou com uma amiga para a "festa do corte do lote", uma festa realizada na conquista do assentamento, quando o Incra demarca os lotes e 
regulariza a ocupação das terras. Por fim, ela disse que quando se mudou com toda a família para o assentamento:

Teve uma festa de final de ano. Assentamento novo, o pessoal sem terra gosta muito de festa. Fomos na festa, o pessoal sempre tratando a gente super bem, uma recepção muito boa. E aí fui mudando... me apegando... vendo aquele povo que eu achava que não trabalhava, não prestava, que eram baderneiros, vagabundos. Foi mudando essa lógica de pensamento...

Paradoxalmente, a entrada no MST seduz e dá medo. A vida que se vislumbra à frente - num futuro bastante idealizado - é boa, mas o cotidiano de um acampamento é bastante difícil, embora não seja solitário.

É preciso ponderar que nem sempre mobilizações como as ocupações dão o resultado esperado. Mesmo assim continuam sendo apresentadas como algo relevante pelas narrativas. Participar de uma ocupação é um marco que demonstra, ao mesmo tempo, coragem, solidariedade e engajamento.

De qualquer maneira, seja na terra escolhida ou na beira da estrada, essas pessoas passam a ser, acampadas, parte de um coletivo organizado, em que todos vivem em condições muito semelhantes. Ganha-se prestígio em meio a esse novo grupo. Por vezes, passa a fazer parte da coordenação do acampamento e a ser respeitada. Quem antes saía em busca de emprego passa a organizar reuniões "para organizar o dia, quem vai fazer o quê, o que tem de trabalho no acampamento".

A vida no acampamento viabiliza realizações. Como no caso de Wanderléia, que pode realizar o casamento de sua filha. Ao continuar a leitura da narrativa, percebe-se que essa foi uma data importante não somente para a mãe, mas também para a mulher, que pode depois de 23 anos de convivência realizar seu próprio casamento.

O casamento da filha e dela, celebrado junto com toda a comunidade, se encontra relacionado ao Movimento, pois foi "graças ao MST" que isso pode acontecer. A reunião e o casamento foram momentos de transformação na vida da colaboradora. Tornaram-se 
momentos de mística pessoal, que contribuíram para o estreitamento dos laços identitários.

A ocupação, o acampamento, a marcha, são, muitas vezes, um processo irracional para a lógica alheia, por isso é comum pessoas fazerem colocações do tipo: como tais pessoas andam tantos quilômetros com seus filhos no colo? Como pequenos agricultores estão lá e não permanecem em suas terras produzindo? Porque eles "invadem" terras alheias e propõem a reforma agrária se querem revolucionar a estrutura social? Assim, a caracterização externa pode taxar as ações dos sem-terra como supersticiosas, místicas ou messiânicas, ao mesmo tempo em que podem ser desqualificadas como "algazarra", negando-os o direito de ser sujeitos de interlocução. E impondo a eles uma lógica externa.

Nos acampamentos são superados alguns preconceitos e encarados outros, as pessoas passam a viver mais juntas, mas nem por isso seu cotidiano é menos sofrido.

No fim da entrevista, com o gravador desligado e a filha ao seu lado, Wanderléia continuou conversando um pouco comigo. Nesse momento a mulher que há seis anos participa do Movimento e ainda está acampada, passando de acampamento para acampamento contou que as filhas antes de entrar no Movimento tinham vergonha até mesmo de ir para a escola. A filha mais velha era a que sentia mais vergonha, segundo a mãe porque ela não tinha uma roupa bonita e o material dela era mais feio que das outras crianças. Wanderléia deu razão à filha, quando contou que muitas vezes não tinha nem absorvente íntimo para usar. Valéria, a filha mais nova, lançou um olhar triste quando sua mãe contou um pouco dessa história. Ela é uma menina de 14 anos e confessou estar cansada de viver acampada, que embora goste bastante do acampamento, o que ela mais queria era uma casa, pois queria viver em algum lugar mais "estável”.

Assim evidenciam-se duas faces da mesma moeda. A vida no acampamento ora é boa, ora é ruim. Ela é includente sem acabar com a exclusão. O acampamento ao mesmo tempo em que propõe um nivel de 
inclusão garante a manutenção da exclusão por não possibilitar condições dignas de vida. Essa dualidade aparece em algumas histórias de vida. Estas mostram uma certa nostalgia à medida que o narrador recorda do acampamento como o lugar do encontro para uma nova vida, onde as crianças ficam juntas, por outro lado outras lembranças podem vir recheadas de sentimentos ruins, pois esse era também o lugar em que não se tinha energia, água, escola, ou mesmo comida para todos.

Outro paradoxo vivido nos acampamentos ocorre em relação à questão do público e do privado. Vale lembrar, portanto, que para falar de acampamento, tem-se que pensar nas diferenças e intersecções das esferas do público e do privado. Ora, dentro de uma “casa” estamos num ambiente totalmente privado, entretanto isto não é completamente aplicável para a vida dos acampados, posto que, na maioria das vezes, estão morando em locais de passagem, locais públicos.

O acampamento seria o "estágio" inicial da luta, criado para ser um lugar passageiro. Mas isso tem acontecido cada vez menos. Há a busca por politicas públicas que se instalem nesse espaço e melhorem a vida das pessoas que moram ali. Esse é o caso da regularização das Escolas Itinerantes (que ocorreu nos estados do Rio Grande do Sul, Santa Catarina e Paraná) que ao mesmo tempo que garantem escolarização para as crianças acampadas, se transformam num fator a mais para que o Estado se acomode com a situação de "transitoriedade permanente" em que vivem essas pessoas.

A introdução, por meio de reivindicações, de politicas públicas no acampamento revela a força do MST. Isso demonstra que os governos começam a dialogar, ao invés de ignorar os acampados. É uma melhoria dessa relação, pois o que existia anteriormente era a imposição de uma política autoritária, que só usava a polícia como "negociadora" em casos de despejo.

Entretanto essa nova relação que está sendo construída revela uma ambigüidade, pois apenas minimiza a situação de 
conflito entre Estado e movimento social e o objetivo final, a Reforma Agrária, é relegado para segundo plano. ${ }^{303}$

O acampamento é um símbolo da luta do MST, por isso existe uma construção de uma memória coletiva que não pode ser apagada. Nessa construção a vida no acampamento é sempre tomada como algo transitório, mesmo que durando anos. Compartilhando dessa "memória coletiva" pode-se perceber nas narrativas um movimento dialético entre o gostar e não gostar, entre o lembrar e não lembrar, entre o estar e não estar neste lugar.

Pode-se dizer também que, para os sem-terra, o acampamento se caracteriza como "lugar de memória", que constitui identidades, muitas vezes antagônicas.

À medida que se indica alguns paradoxos, pode-se traçar um paralelo com as reflexões da historiadora Beatriz Sarlo quando afirma que a memória tende a retomar os "episódios singulares, clamorosos ou terriveis" da vivência desses colaboradores. Neste caso, as narrativas expressam em tom de aventura, experiências bastante duras, traduzindo-as como ocasiões de grande aprendizado.

Cotidianamente, os sem-terra vivenciam as contradições impostas por estar em um movimento social que luta pelo fim da exclusão, mas que não tem condições de promover automaticamente a inclusão de seus membros. Nessa medida, a única coisa que o Movimento pode oferecer é a luta e é a essa esperança que as pessoas se filiam.

Misticas: emblemas identificadores

Nesse momento aproximam-se os significados dados à palavra "mística" pelos narradores com quem se conversou. Nesse

${ }^{303}$ TAKAU JR, Op. Cit, p. 49. 
texto estarão presentes constantemente palavras como: sonho, mística, esperança, utopia, transformação, projeto... Palavras estas nada concretas, mas que sem dúvida, movem as pessoas e as fazem se juntar a lutas que, sem tais sentimentos, seriam impensáveis e insuportáveis.

Pode parecer até mesmo contraditório, no âmbito da ciência e da academia, tratar de tais assuntos que mais dizem respeito a uma espiritualidade que à razão. A partir das reflexões de Foucault sobre o cuidado de si, justifica-se a presente preocupação:

Se, por um lado, historicamente preponderou nas filosofias o âmbito restrito do conhecimento, por outro, Foucault faz ver que filósofos da antiguidade grega e do período helenístico e romano não dissociavam a questão da filosofia (a saber, "como ter acesso à verdade") da questão da espiritualidade (a saber, quais são "as transformações no ser mesmo do sujeito que permitirão o acesso à verdade"). É esta junção, por assim dizer, de filosofia e espiritualidade, da verdade e sua prática que estaria designada na noção de cuidado de si. De sorte que o cuidado de si, assim entendido, remete não somente ao plano da intelecção ou do conhecimento - embora o inclua -, não apenas ao âmbito das teorias - embora as justifique -, não somente à ordem da representação - embora a fundamente -, mas também ao plano das atitudes, ao âmbito do olhar, à ordem das práticas, que constituem todo um modo de existência. ${ }^{304}$

A capacidade de unir esperança à luta e a possibilidade de celebrar cada conquista é o que faz a força desse movimento e une essas pessoas. Seria possivel afirmar, então, que se criam identidades sonhadoras? Sim, mas não só. São também identidades realizadoras, batalhadoras, que se alimentam de mística.

Existe uma dificuldade de falar sobre mística em uma tese. Até certo ponto isto é contraditório, pois se propõe explicar aquilo que, por natureza, não é conceituável, que é inexprimivel e inexplicável. No entanto, posso aceitar o desafio de identificar algumas linhas mestras desta prática. Como apontou a professora de filosofia da linguagem,

\footnotetext{
${ }^{304}$ MUCHAIL, S. T. Cuidado de si e coragem da verdade. In: GROS. Op cit, p. 9.
} 
Patrizia Manganaro, ${ }^{305}$ Mística é um conceito que pode ser relacionado com utopia. Por vezes, a narrativa é a própria concretização dessa utopia, nela passa a existir um novo senso de pertencimento, que supera a exclusão. E mesmo não havendo provas mais concretas, a presença na fala dos entrevistados marca sua existência e importância.

Frequentemente, mística é enquadrada como emocional, intimista. Para entendê-la é preciso pensar na relação entre o físico, o psíquico e o espiritual. A corporeidade viva fala de todo ser que a habita e o seu dizer pertence àquele extraordinário "modus" comunicativo que utiliza o alfabeto dos símbolos. Sendo que símbolo é um sinal concreto que evoca sem revelar, não permite uma apreensão totalizante do que indica: pelo contrário, respeita seu silêncio.

Por ser a mais emocional de todas as estratégias que citamos da formação identitária, a mística não é apenas um apoiador do processo de identificação, está presente em todos esses e, portanto, participa de modo capital da fundamentação de uma identidade central do Movimento Sem Terra. Para pensar a mística é importante remeter-se à relação dinâmica "Eu-Tu" pessoal e recíproca, em uma espécie de atravessamento do tempo que se anuncia como acontecimento tenso entre o 'já' e o 'ainda não' ${ }^{306}$, ou seja, entre a sua verdade vivida, atuada e conhecida e o que está por vir.

A mística alimenta o espírito da luta coletiva, fazendo com que as pessoas sintam e sonhem juntas. Os narradores apresentaram várias explicações para o que é mística, dentre elas:

Essas homenagens são as místicas. Cantam música, chamam as pessoas na frente e homenageia. Por exemplo, entregam a bandeira, o boné e aplaudem as pessoas que são homenageadas. É um calor humano, é muito bom... As festas do MST. O MST não é rico, a nossa riqueza é a união. Eu me lembro de uma mística que me tocou lá no Manuel Congo, quando o acampamento fez um ano. A gente fez uma festinha e uma mistica, que homenageava os amigos do Movimento.

\footnotetext{
${ }^{305}$ MANGANARO, P. Alteridade, filosofia, mística: entre fenomenologia e epistemologia. Disponível em http://www.fafich.ufmg.br/ memorandum/artigos06/artigo01.pdf, acessado em 12/07/06.

${ }^{306}$ MANGANARO, P. Alteridade, filosofia, mística: entre fenomenologia e epistemologia, p.5.

Disponível em http://www.fafich.ufmg.br/ memorandum/artigos06/artigo01.pdf, acessado em 12/07/06.
} 
Fez uma mística, com a gente entrando na terra, parecia que estava vivendo aquilo de novamente!

Nesse fragmento da narrativa de Wanderléia podemos ver esses diferentes tempos, o tempo do vivido (passado e presente), mas também o tempo do porvir (futuro), pois logo será tempo de viver a mística e entrar em uma terra novamente, desta vez para ficar.

Aquiles usa uma terminologia religiosa para definir mística:

...mística é uma conversão que desperta dentro da gente a necessidade de estar permanecendo, construindo. A mística, cada dia que passa você vai construindo. Inclusive depois de amanhã a gente estar participando de uma mística fenomenal! A gente nem sabe direito que papel vai ter... Hoje à noite vou estudar o meu papel. Sei que a mística é o resgate, da cultura brasileira, principalmente na Bahia. Candomblé, índio, isso e aquilo outro... Estamos firme na questão da mística para despertar nos companheiros a vontade de viver e lutar.

Viver e lutar, para Aquiles, são sinônimos. Parece claro pensar o MST como um movimento que propõe mudanças significativas na ordem social e que sonha com uma sociedade mais justa. Dessa forma, podemos vê-lo como um movimento revolucionário, mas não só. A palavra sonho faz referência ao conteúdo utópico de sua luta. Essa sociedade mais justa nunca se concretizou no passado, mas seus membros acreditam em sua realização no futuro. Essa "fé" por vezes toma uma forma milenarista ${ }^{307}$ ou mesmo messiânica ${ }^{308}$. A identidade dos membros do MST está relacionada a seu trabalho vinculado à terra. Existem elementos da cultura camponesa que surgem em suas vivências, mesmo que nem todos tenham essa origem.

Aqui, propõe-se entender o sentido do processo de identificação observado. Como base para essa análise tomam-se as diversas estratégias e ações, que vêm sendo lembradas em registros de narrativas realizadas. Pode-se destacar as ações de ocupação (de terras, prédios públicos etc.), mas também práticas cotidianas, como a mística. Acredita-se que essas estratégias de luta imprimam, em seus sujeitos,

\footnotetext{
${ }^{307}$ HOBSBAWM, E. Rebeldes primitivos. Estudos sobre formas arcaicas de movimentos sociais nos séculos XIX e XX. Rio de Janeiro: Zahar Editores, 1970.

${ }^{308}$ QUEIROZ, M. I. P. Messeanismo no Brasil e no mundo. São Paulo: Alfa-Omega, 2004.
} 
formas de pensar resultantes do agir, portanto, formam laços de união dessa comunidade e até mesmo suas identidades. Uma delas é a mística:

A mística não é apenas a "alma" do sujeito coletivo Sem Terra e da identidade do MST, que se revela como uma paixão contagiante, que nos ajuda a "sacudir a poeira e dar a volta por cima", que nos coloca a caminho e nos encoraja a vencer obstáculos. A mística é a energia que perpassa o cotidiano e que nos ajuda a vivenciar os valores e nos desafia a ir concretizando, no aqui e agora, o projeto popular.

A mística é também um dos mais densos momentos de formação humana: ela cola o conhecimento à emoção, através da cultura. Nela expressamos vivências e conteúdos humanos fundamentais através da poesia, do teatro (encenação), da música, do canto, da dança, dos gestos, dos símbolos do MST, das ferramentas de trabalho, dos elementos da natureza, do resgate da memória das lutas e do exemplo de grandes lutadores e lutadoras da humanidade, ... Ela permite vivenciar um mesmo sentimento, assumir uma determinada postura, sentir-se parte de uma mesma identidade (MST), envolver as pessoas em um mesmo movimento, levando-as a se assumir como lutadores e lutadoras do povo.

A mística irriga, pela paixão, a razão, nos ajudando a ser mais humanos, dispostos a desafiar pessoal e coletivamente os nossos limites; nos impulsiona a ir além do esperado, alimenta os valores humanistas e socialistas e nos faz sentir membros de uma grande família: somos Sem Terra. 309

Vê-se neste texto a relação estreita que é estabelecida entre os processos de identificação desta comunidade com a mística, que se torna uma cerimônia de identificação. Estas são os momentos que precedem, acompanham e encerram qualquer atividade organizada pelo MST, quando os sem terra escolhem um tema, selecionam e recitam textos literários e políticos, cantam músicas de artistas locais, nacionais ou do próprio movimento social, exibem imagens audiovisuais, fotográficas ou próximas de uma arte de inspiração muralista, e ainda interpretam pequenas peças de teatro em geral por eles inventadas com base nas concepções do Teatro do Oprimido ${ }^{310}$.

\footnotetext{
${ }^{309}$ MST. Caderno de Educação, $n^{\circ} 11$. Educação de jovens e adultos: sempre é tempo de aprender. São Paulo: Iterra, 2003, p. 49.

${ }^{310}$ Teatro do Oprimido é o nome dado por Augusto Boal para uma forma radical de representação teatral. Boal o definiu da seguinte forma em uma entrevista: "Teatro do Oprimido é um teatro sem dogmas e
} 
Na visão de Daniel:

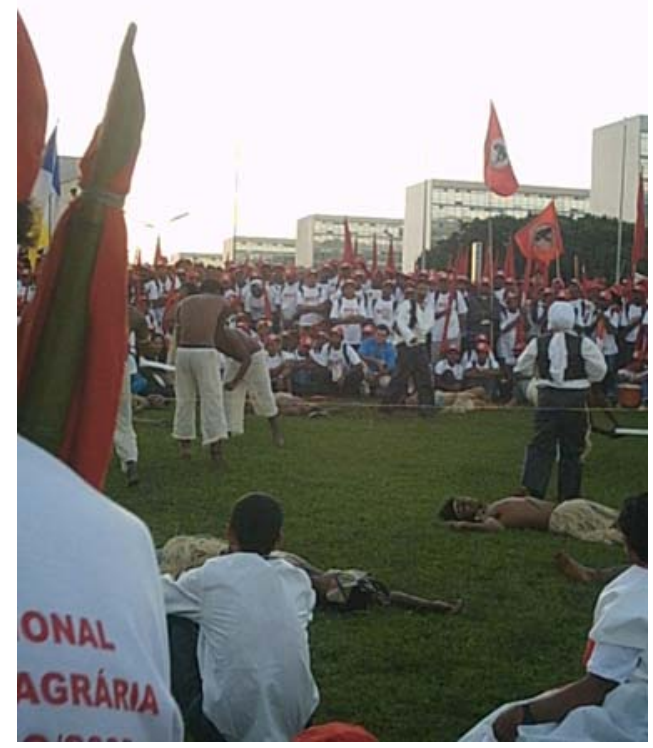

A mística tem vários significados. Mas para mim, acho que ela tenta passar alguma coisa que aconteceu... O que a gente quer passar para as pessoas depende do tema que a mística trabalha, de como ela é feita, de como ela é pensada. Às vezes tem que estar horas pensando.

Mística sobre a colonização realizada em frente ao Congresso Nacional - Brasília/DF.

Quem pensa a mística tem uma tarefa importante nas mãos. Diversos são seus elaboradores, qualquer membro do MST ou pessoa convidada para participar de um evento pode fazer parte da equipe de elaboração de uma mística. Também diversas são suas fontes de inspiração. De forma geral são utilizadas poesias e a literatura em geral, músicas, imagens, que quase sempre remetem às experiências de exclusão, de marginalidade e de resistência dos trabalhadores. A mística se torna o espaço de recriação e de transmissão dessas experiências, onde as práticas artísticas e culturais muitas vezes partem das experiências vividas pelos sem-terra e por darem sentido a elas são retomadas e incorporadas pelas tramas biográficas. A partir das histórias de vida, contadas e compartilhadas no sentido benjaminiano, muitas poesias, músicas, imagens e peças teatrais são criadas e vivenciadas nas místicas. Ao mesmo tempo, é comum que os narradores contem momentos de extrema emoção a partir das lembranças de uma mística.

realizado por meio de um conjunto de exercícios que ensinam o ser humano a utilizar uma ferramenta que ele já possui e não sabe. O homem traz esta característica teatral dentro de si. O que este tipo de teatro faz é liberar esta capacidade e ensinar à pessoa como dominá-la.” In: http://www.sinpro-

rs.org.br/extra/ago99/entrevista.htm, acessado em 10/06/2007. 
Como as místicas contribuem para a formação de uma identidade coletiva, se são pensadas e lembradas de formas tão particulares? Penso que o que ocorre é que esses momentos acabam por se tornar marcantes, determinantes, explicadores e inspiradores das trajetórias pessoais, de vários dos sem-terra e, portanto, tornam-se momentos marcantes, determinantes, explicadores e inspiradores de toda uma coletividade. Transformam-se em momentos históricos individuais e coletivos que conformam memórias (individuais e coletivas), em permanente mudança e re-significação. Essas memórias dinâmicas criam e recriam as subjetividades plurais e contraditórias que alimentam as identidades do movimento social, aqui compreendidas como processos que abarcam um sentido de ligação e continuidade num tempo e num espaço e, sobretudo, de pertencimento a um grupo.

No caso dos sem-terra, memórias, subjetividades e identidades se (re) constroem permanentemente em confronto e em diálogo com as formas de narratividade caracterizadas pelas diversas formas de manifestação, místicas ou não.

"Revolta mística": tradição e transformação

A palavra mística não deixa esquecer das "origens sócioreligiosas do Movimento dos Trabalhadores Sem Terra do Brasil"311, vinculadas a ação as Comunidades Eclesiais de Base (CEBs), da Comissão Pastoral da Terra (CPT), impulsionadas pela Teologia da Libertação. Mas para pensar o MST e sua mística é preciso colocar mais tintas e mais cores nesse quadro:

A mística do MST tem raízes no milenarismo camponês. Em todo o mundo e desde sempre, o camponês é a pessoa que aspira e acredita na possibilidade de um mundo justo e em harmonia com a natureza. Em nome dessa utopia, as massas

\footnotetext{
${ }^{311} \mathrm{Um}$ texto com este nome, que trabalha com as questões aqui apontadas, foi escrito por LÖWY, M. in Revista Cultura Vozes, n.3, 2000, pp. 12-20. Sobre o mesmo assunto o autor publicou o artigo A mística da revolução, FSP, 02/04/2001, Caderno Mais!, p.16.
} 
rurais têm se levantado, através dos tempos, contra o mundo real, sempre injusto, cruel e desequilibrado. [...]

A mística camponesa provoca antagonismos, mas gera igualmente adesões definitivas e tem efeitos concretos. Crêem alguns que não, que as rebeliões camponesas não conduzem a uma ordem social nova porque o culto do passado não tem o poder de organizar o futuro. Sem entrar no mérito desta discutida tese, o fato é que todas as revoluções sociais do século XX tiveram por base e condição de êxito a esperança camponesa em um mundo melhor.

Pois bem, a base da mística do MST é essa cultura da população rural do país. É na força telúrica dessa população que o movimento alicerça sua fé na possibilidade de mudança e extrai os valores, os sentimentos, as intuições que alimentam a sua mística. A esse alicerce somam-se duas grandes vertentes místicas: a cristã e a socialista-marxista. ${ }^{312}$

As místicas favorecem um espírito de comunhão ao misturar cristianismo e socialismo. Essa celebração acontece no início e no final de atos políticos, reuniões de trabalho, atividades de formação, materializando o significado das lutas por meio de uma simbologia e uma liturgia. Segundo Sampaio:

Toda mística expressa-se numa liturgia, ou seja, numa linguagem de símbolos que une a palavra ao gesto. Cada liturgia é uma estética que traduz a visão transfigurada do mundo, "resgate de um drama que conhecerá um fim bom".

A liturgia do MST é bastante diversificada e muito bela, na singeleza das formas que desvelam a presença da cultura do povo rural. Essa cultura expressa a luta de uma população desde sempre oprimida por um quotidiano vivido no limite da sobrevivência física; humilhado pela prepotência da classe social que a explora; aviltado por um trabalho que se transformou em jugo. O fantástico é que, apesar dessa condição de vida, o camponês brasileiro tenha sido capaz de produzir beleza, solidariedade, ternura, alegria. 313

Os símbolos são aliados desses momentos:

A apropriação simbólica permite que as pessoas mantenham seu estado de comunhão, convencendo-se da necessidade da luta no dia-a-dia, num aprendizado de novos valores que passa a ser ritualizado. [...] A mística cria novos heróis, diferentes dos já sagrados pela história oficial. Esses heróis são os próprios participantes do MST [...] que também

\footnotetext{
312 SAMPAIO, P. A. Op. Cit.

${ }^{313}$ Idem.
} 
reinventam a história elegendo nomes com um passado de lutas populares. Che Guevara, Chico Mendes, Antônio Conselheiro mesclam-se com lembranças dos indios que resistiram à colonização, assim como dos trabalhadores rurais e religiosos assassinados na luta pela terra. ${ }^{314}$

A identidade oficial do Movimento Sem Terra é uma criação, que usa elementos da memória da luta pela terra, da exclusão social, da busca de justiça e cidadania, o sonho de um mundo melhor, como elos para a união de diversos trabalhadores em torno de uma mesma bandeira. Essa identidade concilia elementos religiosos de esperança e fé. Ou seja, inspirada na Teologia da Libertação e carregando consigo traços do que Hobsbawm chamou de "relações políticas dos camponeses 'tradicionais"'315, aponta para uma identidade messiânicamilenarista.

Evidentemente, não se trata de defender raízes tradicionais de um campesinato que nem se sabe ao certo se um dia existiu no Brasil. O que se quer é marcar um diálogo com a produção de Hobsbawm e Löwy sobre o assunto, pois apontam para uma linha interpretativa sobre movimentos sociais do campo.

Seguindo a sugestão deixada por Löwy ${ }^{316}$ foram realizados cruzamentos sobre os estudos feitos sobre o MST a fim de verificar se o milenarismo revolucionário - "a forma mais radical de resistência camponesa contra a modernização capitalista"317 - tal como foi estudada por Hobsbawm - permanece como fenômeno, no presente, na ação de movimentos como o MST.

Além disso, Löwy, citando Hobsbawm, faz o balanço da importância da população rural, que até a década de 50 era a maioria no mundo todo, e coloca sua tomada de consciência como explicação para o século XX ser tão revolucionário. ${ }^{318}$ Ao ler essas reflexões fui

\footnotetext{
${ }^{314}$ RIBEIRO, SANTOS e MEIHY, Op. cit., p.248.

${ }^{315}$ HOBSBAWM, E. Pessoas extraordinárias: resistência, rebelião e jazz. São Paulo: Paz e Terra, 1998. p. 215.

${ }^{316}$ LÖWY, M. “Do Capitão Swing a Pancho Villa: resistências camponesas ao capitalismo na historiografia de Eric Hobsbawm”. MIMEO, s/d p. 1-10.

${ }^{317}$ Idem, p.1.

${ }^{318}$ HOBSBAWM, E. Op. Cit, 1970, p.23.
} 
conduzida a pensar sobre o papel de um movimento como o MST, que surge no final do século XX impulsionado por uma tomada de consciência, possibilitada pela abertura politica, vivida no Brasil dos anos 80, e contraditoriamente inspirado em idéias socialistas que viviam uma grande crise, que culminou nas quedas do muro de Berlim em 1989 e da União das Repúblicas Socialistas Soviéticas em 1991. Para eles, esse é um movimento herdeiro de uma história revolucionária, mesmo tendo nascido em um momento no qual os ideais do socialismo viviam este refluxo.

Os camponeses do MST não acreditavam que a modernização, ou seja, a irrupção do capitalismo nas sociedades tradicionais, fosse uma catástrofe, como apresenta Hobsbawm. Mas também, tal como é realizada, ela não é celebrada. As mudanças no modo de vida estão acontecendo mesmo com as resistências em aderir a esses novos projetos.

Mudanças representativas podem ser percebidas nas novas formas de produção implementadas. As vantagens dessa proposta refletem-se na maior produtividade da terra, posto que os assentamentos passam a ter uma lavoura mecanizada, melhorando também a qualidade de vida do trabalhador rural. A mudança do tipo de trabalho ultrapassa a condição do fazer manual, e propõe a esses indivíduos um pensar coletivo.

Ao mesmo tempo em que se leva em conta essas idéias traçadas inicialmente por Hobsbawm, é relevante marcar que o ponto de vista aqui defendido é diferente do apresentado pelo historiador em dois aspectos: Primeiro, no que toca à questão do banditismo. Nessa pesquisa, o MST é visto como um movimento que trabalha na maior parte de suas ações dentro da lógica legal e institucional. A questão das ocupações - ação que aproxima o MST do método de resistência desses grupos "primitivos", nas palavras de Hobsbawm - também merece atenção. A ocupação, ação em primeira instância ilegal, busca a revisão de uma situação injusta e por vezes também ilegal. Por meio dela, 
consegue-se a aceleração do processo de desapropriação, sendo assim, um forte instrumento de pressão.

O objetivo da ocupação é negociar com os governantes saídas para os problemas dos sem-terra e tornar produtivas terras ociosas. Nesse sentido a ocupação é comparada ao direito de greve dos trabalhadores urbanos. Um instrumento de luta para exigir seus direitos. Os sem-terra não têm como fazer greve. Sua forma de pressionar é ocupar o latifúndio, para mostrar que existem terras ociosas e gente capacitada e disposta a trabalhar a terra para produzir alimentos. ${ }^{319}$

A criminalização situa-se justamente quando essas ações começam a surtir efeito e a ameaçarem o capital fundiário concentrado. Isto faz com que o Estado brasileiro, defendendo a propriedade privada, declare, arbitrariamente, que "terras invadidas", independemente de sua situação legal, não podem ser alvo da Reforma Agrária. Duas idéias estão presentes neste posicionamento: garantir o não cumprimento da lei que estabelece o valor social da terra; e iludir-se, ou iludir outras pessoas dizendo que o Brasil tem um plano de Reforma Agrária. O que comumente acontece é confundir Reforma Agrária com politicas de assentamento paliativas, frente ao imenso problema da concentração fundiária brasileira.

O segundo ponto dissonante desta análise é o pressuposto de que haja uma base mística e tradicional comum a esses movimentos, ou a esses grupos de camponeses. Essa ressalva é feita, porque no Brasil tem-se que enfrentar a discussão se há mesmo uma base tradicional de formação do camponês, a medida que não se pode dizer que a maior parte das terras brasileiras tenha sido apropriada e trabalhada por pessoas livres que tivessem tradição na atividade agrícola. Assim, é preciso, no mínimo, lembrar que existem distinções entre o camponês brasileiro e o inglês.

Deste modo, em geral, as ações do MST não podem ser denominadas como "primitivas", mas algumas ações do presente podem ser aproximadas de eventos descritos pelo historiador inglês. A

${ }^{319}$ STÉDILE e GÖRGEN, Op. Cit., 1993, p. 59-60. 
destruição de propriedades ou mesmo o abate de alguns animais podem da mesma maneira com que na revolta dos trabalhadores agrícolas ingleses em 1830, ser interpretados como "uma resistência improvisada, espontânea, "arcaica" contra a lógica do mercado, em pleno triunfo do capitalismo rural". 320

Esses atos são formas de expressão violenta de pessoas que viveram anos em condições de vida bastante precárias, à margem da sociedade e desempregadas. A própria situação de exclusão pode gerar uma forma agressiva de agir e tais pessoas enfrentaram um processo de “desumanização”. Mesmo que a presença desses eventos não possa ser negada, é importante frisar que ela não é regra no comportamento dessas pessoas. Talvez aqui esteja uma das forças deste movimento social, que age como regulador nestas situações, promovendo um debate constante sobre a melhor forma de lutar pela terra.

Para reverter este processo, o MST se lança na defesa das camadas rurais mais pobres, num desejo de estabelecer uma relação humana de trabalho com a terra. Nesse sentido, é possivel caracterizar o MST como um movimento romântico, não reacionário ou passadista, por querer a volta ao passado, pois não o quer. Recusa-se a entrar de cabeça no mundo capitalista, por auto-preservação, por consciência de que seu lugar nesse cenário será sempre periférico e por continuar acreditando que um outro modelo de desenvolvimento é possível.

O MST não aceita esse papel reservado a ele pela lógica do capital e se coloca no centro promovendo um debate em torno da questão agrária. Ao se organizarem, esses trabalhadores rurais revelamse como um forte movimento social de resistência. Conseguem, ao mesmo tempo, provocar o debate, politizar-se, sensibilizar pessoas e efetivar a desapropriação de terras.

Paralelamente, pode-se considerar o MST como um movimento milenarista à medida que acredita em uma mudança radical do mundo que se traduzirá no futuro. Essa transformação não virá pura e simplesmente pelo passar do tempo. É preciso fazer algo. Por

${ }^{320}$ HOBSBAWM, E. citado por LÖWY, M. Op. Cit., mimeo, p.1. 
isso ele também é um movimento revolucionário. "As revoltas de camponeses em massa contra esta nova ordem vivida como insuportavelmente injusta, tornam muitas vezes uma forma milenarista". 321

Incorpora-se aqui esses traços milenaristas, pois ajudam entender a identidade que está em construção. Sem dúvida, o MST é resultado de questões objetivas como os problemas econômicos vividos por sem-terras. No entanto, somente isso não explica sua força e seu espírito de grupo. Um aspecto bastante subjetivo na constituição desse coletivo é a afinidade que faz com que pessoas com terra, assentados e pequenos produtores rurais, continuem parte do Movimento. Como disse Löwy:

...graças à problemática do milenarismo, a historiografia de Eric Hobsbawm integra toda a riqueza da subjetividade sócio-cultural, a profundidade das crenças, sentimentos e emoções em sua análise dos acontecimentos históricos que não são mais nessa, perspectiva, percebidos simplesmente como produtos do jogo 'objetivo' das forças econômicas ou políticas. Essa abertura à dimensão subjetiva se traduz também pelo fato de que a análise em termos de classes sociais não elimina o lugar irredutivel dos indivíduos tanto célebres como desconhecidos - a quem o historiador amiúde dá a palavra. ${ }^{322}$

Embora seja necessário distinguir os movimentos milenaristas e messiânicos primitivos dos revolucionários modernos, é importante ressaltar que o próprio MST elege como um de seus heróis Antônio Conselheiro, líder do movimento de Canudos, caracterizando-se como herdeiros dessa luta e de outras emblemadas pelas ligas camponesas.

O MST não pode ser compreendido apenas por seus últimos vinte anos. Na verdade ele é fruto de uma longa história realizada por nosso povo. Nós somos filhos do povo brasileiro. Filhos que necessariamente temos nossos pais, avós, e antepassados na vida do povo brasileiro. Assim, só existimos

\footnotetext{
${ }^{321}$ LÖWY, M. Origem sócio-religiosas do Movimento do Trabalhadores Sem Terra (MST) do Brasil. Citando HOBSBAWM, E., Primitive rebels. Studies in archaic forms of social movement in the $19^{\text {th }}$ and $20^{\text {th }}$ centuries. New York, Norton Library, 1959, p.3, 67, 119. In Revista Cultura Vozes, n.3, maio/junho de 2000, p.13.

${ }^{322}$ LÖWY, M. Op. Cit. Mimeo, p. 2-3
} 
hoje, porque antes de nós, o povo brasileiro organizou outras formas de organização e de luta por justiça no meio rural. Somos herdeiros das lutas históricas dos povos indígenas. Somos herdeiros das lutas históricas dos negros pela liberdade, quando fugiam, e conquistavam sua liberdade e construíram os quilombos. Somos herdeiros dos primeiros movimentos camponeses. Alguns se transformaram em verdadeiras epopéias, como Canudos, Contestado, Caldeirão. $\mathrm{E}$ muitos outros não foram registrados pela história oficial da classe dominante, mas certamente houve sempre muitas lutas sociais, nos cafezais, nos canaviais, e por esse sertão afora.

Somos herdeiros da experiência de organização classista dos camponeses, que construíram muitas organizações nacionais a partir da década de 50, e que depois foram massacrados pela ditadura militar, como as ULTABs - União dos Lavradores e Trabalhadores Agrícolas do Brasil, as Ligas Camponesas e o Master - Movimento dos Agricultores Sem Terra. ${ }^{323}$

A partir dessas reflexões, pode-se salientar que o MST brasileiro, que tem uma de suas raízes sócio-culturais na Teologia da Libertação, se caracteriza também por uma mescla surpreendente de religiosidade popular, revolta camponesa "arcaica" e organização "moderna" em uma luta radical pela Reforma Agrária e, finalmente, por uma sociedade sem classes.

Para o movimento social é importante estabelecer alternativas politicas, pois isso vai dar razão a sua luta. "Mas por que comprometerse politicamente? Para efetuar uma mudança social, econômica e politica, que permitisse que as classes exploradas (primeiro), os pobres (mais teologicamente) e o povo latino-americano (por último) alcançassem uma vida justa, humana, realizada"324.

É importante dar continuidade às propostas encaminhadas pelos teólogos da Libertação. No entanto, como movimento independente, o MST trilha seu próprio caminho, muitas vezes repensando decisões e discutindo novamente algumas práticas, por vezes se tornando mais dogmático e adaptando decisões/ações as suas próprias demandas.

\footnotetext{
${ }^{323}$ RIBEIRO (org), Op. Cit., 2004, p. 9-10.

${ }^{324}$ DUSSEL, E. Teologia da Libertação e marxismo. In: LÖWY, Michael (org). O marxismo na América Latina: uma antologia de 1909 aos dias atuais. São Paulo: Ed. Fundação Perseu Abramo, 2003, p. 491.
} 
Não é o caso de criar uma nova teoria (nem capitalismo, nem socialismo), mas pensar as adaptações necessárias para a vida humana no presente.

O desafio, portanto, é perceber na atuação do Movimento uma re-significação dos conceitos de revolução ou reforma. A identidade que se forma faz referência ao que Boff define como "utopia de Brasildiferente"325. A sociedade brasileira que se quer é criada "a partir de baixo, democrática, popular, aberta à nova fase da Humanidade, a planetária, mas de forma soberana e não subalterna, a sociedade na qual todos possam caber - a natureza incluída"326. Uma sociedade em que se possa trabalhar, comer, estudar, se tratar quando doente, enfim, viver dignamente. No entanto, esse querer não resulta de um mero voluntarismo, "vem carregado de reflexão acumulada, paciência histórica e atenção às condições existentes ou a criar"327.

O MST vem aprendendo, nesses pouco mais de 20 anos de existência e resistência, a ser mais aberto ao subjetivismo, o que era apenas um sonho distante cercado por uma prática objetivadora, passa a acontecer internamente. Rompe-se assim com uma ótica objetivista, marxista, e reconhece-se o papel da subjetividade humana na história. "A prática revolucionária extrapola o conceito e não se esgota em análises estritamente científicas, pois encerra necessariamente dimensões éticas, místicas e utópicas". ${ }^{328}$

Frei Betto, fazendo relações entre o marxismo e cristianismo conclui seu artigo da seguinte forma:

Marxistas e cristãos têm mais arquétipos em comum do que supõe a nossa vã filosofia. Um deles é a utopia da felicidade humana no futuro histórico - esperança que faz mística a prática de inúmeros militantes que não temem o sacrifício da própria vida. Marx chama esta plenitude de reino da liberdade e, os cristãos, de reino de Deus. No terceiro volume de $O$ Capital ele escreve que 'o reino da liberdade inicia ali onde cessa o trabalho condicionado pela necessidade e pressão externa; o reino da liberdade está situado, pois, e

\footnotetext{
${ }^{325}$ BOFF, Op. Cit, 2004.

${ }^{326}$ Idem, p. 54.

${ }^{327}$ Idem, p. 60.

${ }^{328}$ BETTO, Frei. Cristianismo e marxismo. In: LÖWY, Op. Cit, 2003, p. 486.
} 
por força das coisas, além do âmbito da produção material'. Ora, nada na política ou na história garante a realização dessa meta, como também a salvação esperada pelos cristãos não tem explicação, é dom de Deus. Mas há, no mais profundo do nosso ser, o desejo comum de inúmeros marxistas e cristãos de que a humanidade elimine todas barreiras e contradições que dividem ou separam os homens. E a esperança incontida de que o futuro será como a mesa posta em torno da qual, irmanados, todos haverão de partilhar a fartura do pão e a alegria do vinho. ${ }^{329}$

Nesse sentido, parte das lideranças do Movimento é marxista a medida que se nutre da originalidade de uma teoria que está vinculada à prática revolucionária. É marxista também ao comportar uma relação dialética consigo mesmo que "confere e contesta a teoria que inspira e orienta" 330 .

O Movimento está sempre se repensando. Ao final de cada reunião é feito um momento de avaliação onde todos podem se posicionar pontuando críticas e sugestões, dizendo o que funcionou e o que não funcionou, o que foi aprendido e o que ainda está nebuloso. Essa reflexão organiza novos rumos para futuras negociações, convênios, conversas e reuniões.

Talvez na contramão da afirmação de que "a religião é o ópio do povo", religião e marxismo se encontram no cotidiano de práticas políticas, revolucionárias e místicas do MST. As "classes populares", portanto, apoiando-se em sua fé e respondendo às suas próprias necessidades, passam da crença à militância. $O$ cristianismo, reinterpretado, "passa a revelar seu caráter libertador como expressão de resistência e luta dos oprimidos". 331

O MST, em torno deste sonho, agregou forte componente emocional, místico - termo usado pelos próprios militantes para designar o estado de espírito dos participantes - ou milenarista, em sentido amplo. Reuniu centenas de milhares de camponeses, parceiros e trabalhadores agrícolas. E se converteu atualmente no movimento

\footnotetext{
329 Idem, p. 489.

${ }^{330}$ Idem, p. 486.

${ }^{331}$ Idem, p. 487.
} 
social mais importante do Brasil e na força de protesto principal contra a política de modernização neoliberal dos sucessivos governos brasileiros.

Educação e formação: bandeiras de luta

A questão do estudo que é o primordial. E as pessoas às vezes não conseguem admitir, um sem-terra estudando. Dizem: "para quê esse povo quer estudar?" Acho esses valores do estudo, da disciplina, do cuidado com o ser humano, os maiores da nossa organização. O Movimento tem muito esse cuidado que acho que é a injeção que vai animando a gente. Elizandra

Para falar de consolidação identitária preciso falar do processo de formação e educação. Talvez uma explicação advenha do fato de ser professora e acreditar na educação como elemento central para a formação do ser humano, ou ainda, por ter atuado diretamente no Setor de Educação do Movimento Sem Terra durante cerca de quatro anos. De uma ou outra forma, penso que não se pode deixar de observar que é notável a importância que o MST dá à educação que pode ser aqui compreendida como escolarização formal, mas também como um processo de formação mais amplo que envolve toda uma proposta de mudança de valores. Assim, colaboradores como Daniel relacionam sua permanência no movimento à educação:

O que me fez ficar, acho que foi mais por ser educador. Por exemplo, eu trabalho com as crianças, e eu gosto de fazer isso. É um trabalho gratificante ver a criança aprendendo, se ensinar a ler e escrever.

Além da educação básica, pela qual educadores como Daniel são responsáveis, há também uma preocupação com a formação desses educadores. Um dos palcos em que a educação ganha centralidade são os cursos de formação, aos quais vários narradores se referiram. Nessas oportunidades o Movimento reúne vários de seus militantes e realiza 
uma sensibilização junto ao processo de formação. Foi o que contou Ana Paula:

O primeiro momento que me emocionei foi na noite cultural, que teve uma mística muito bonita. Muito bonita mesmo! A $\mathrm{CPP}^{332}$ que fez. Foi sobre a integração, o compartilhar. Nessa mística todo mundo pegava uma fita e colocava no braço do outro. Teve uma falação muito bonita sobre o peso da responsabilidade nossa. E naquele momento eu senti o quanto eu era importante! Para o povo do meu assentamento, para as pessoas. O quanto minha responsabilidade era grande. E eu não podia deixar, tinha que carregar o peso dessa cruz.

E esse "peso", ao qual se referiu Ana Paula, parece ter sido recompensado, pois:

Quando terminou a primeira etapa do curso e a gente foi para o momento comunidade, teve uma mística muito bonita. Nesse momento todo mundo chorou, apesar de ser primeira etapa e de todo mundo estar se conhecendo. Foi um momento muito bonito! Todo mundo se despedindo.

A exemplo de narrativas como essa, retoma-se a idéia de que essas pessoas se tornam úteis/necessárias, pois precisam fazer algo a alguém. Assim, o conhecimento passa a ter uma utilidade prática à vida e às pessoas.

É possivel apontar também o curso de Pedagogia da Terra para Ana Paula, como um ritual de iniciação e de entrada para o Movimento.

Aî daí começa a ter uma relação maior com Movimento Sem Terra. Fui para segunda etapa e foi melhor ainda. Hoje está com três anos, está quase no final do curso! Vai terminar no final do ano. Eu percebo o quanto cada etapa que passa, a cada atividade, a gente vai aumentando o nivel de consciência e de certeza de que aqui é o lugar onde tem que estar. Junto com o povo. Nós precisamos uns dos outros para poder superar esse problema, essa desigualdade social. Tudo isso que nos oprime e nos exclui.

\footnotetext{
${ }^{332}$ CPP - Coordenação de Política Pedagógica.
} 
Há, no entanto, uma contradição entre o estar junto e a prática de como se livrar de tudo que oprime e exclui. A própria Ana Paula, em sua história, contou como, logo ao entrar no quarto, foi olhada por algumas militantes mais velhas de um modo nada acolhedor: "Elas me olharam de um jeito desconfiado [...] imaginavam que eu era uma menina rebelde que não ia ficar ali de jeito nenhum.” Nessa passagem percebe-se a existência de um preconceito de militantes mais antigos em relação aos jovens. Assim evidencia-se um contra-senso, pois ao mesmo tempo em que se quer/precisa incluir e empoderar adolescentes e jovens na luta, há uma resistência em fazê-lo.

Sobre o curso de Pedagogia da Terra cabe explicar que geralmente são cursos organizados pela Pedagogia da Alternância ${ }^{333}$. Prática educativa que prevê que o aluno revese seu tempo entre estudos na escola - chamado de Tempo-Escola - e atividades junto à comunidade - denominado Tempo-Comunidade, de forma a desempenhar em tempo integral cada uma dessas etapas. A Pedagogia da Alternância vem sendo apresentada como uma alternativa bastante viável para a Educação do Campo já que com ela é possível se definir um calendário em que a criança e principalmente o jovem, possa estar em casa nos tempos de plantio e colheita. A descrição do "tempo escola" é feita por Ana Paula:

A gente ficava 70 dias lá estudando, cedo, tarde e noite. À noite eram questões mais gerais do Movimento, formação, diversos setores, enfim, do conjunto do Movimento. E, durante o dia, são as questões mais da universidade, da grade curricular do curso. Depois do Tempo-Escola que a gente fica lá, retorna e tem o Tempo-Comunidade. Aí vinha um monte de tarefas para a gente fazer no estado, no assentamento, na região. Mas para mim era normal aquilo ali, porque eu tinha que fazer independente do curso porque estava na direção. Tinha que contribuir, fazer as atividades. Mas só que além de eu cumprir as atividades, tinha que fazer relatórios, leituras dirigidas...

\footnotetext{
${ }^{333}$ Há muitos trabalhos sobre o assunto, dentre eles destaco: CALIARI, R. O. Pedaggia da Alternâncias e desenvolvimento local. (Dissertação de Mestrado). Administração, Universidade Federal de Lavras, MG, 2002; e PIZETTA, A. J. Formação e práxis dos professores de escolas de assentamentos: A experiência do MST no Espírito Santo. (Dissertação de Mestrado). Educação, Universidade Federal do Espírito Santo, 1999.
} 
Esses cursos preparam a militância, à medida que trabalham as linhas políticas do Movimento, ao mesmo tempo que capacitam professores para melhorar seus conhecimentos de conteúdo e suas práticas pedagógicas. Questão bastante importante, principalmente se for levada em conta a baixa formação dos professores que dão aula nas áreas rurais, em todo o país.

Quando narradores, como Daniel, destacam a importância de uma educação que parta da realidade do aluno, demonstram sua sintonia com as posições defendidas pelo educador Paulo Freire ${ }^{334}$.

Freire defendia uma educação desalienante e ligada ao universo do educando. A educação para Freire era um ato revolucionário e humanizador. Assim, para ele, educar era transformar a realidade. Em tom de denúncia apontou:

Quem atua sobre os homens para, doutrinando-os, adaptálos cada vez mais a realidade que deve permanecer intocada, são os dominadores. [...]

Esquecem-se de que seu objetivo fundamental é lutar com o povo pela recuperação da dignidade roubada e não conquistar o povo. Este verbo não deve caber na sua linguagem, mas na do dominador. Ao revolucionário cabe libertar e libertar-se com o povo, não conquistá-lo. 335

E ao dar exemplos de sua prática pedagógica, Daniel demonstra como acontece nos acampamentos uma educação que parta do educando e que portanto possa ser libertadora, porque entendida.

Por exemplo, não podemos ensinar para uma criança do campo que não conhece o mar o "b" de baleia, afinal ela talvez não conheça uma baleia, ou mesmo o "a" de avião, que ela vê que passa lá em cima da roça. Ela vai ver o avião, mas são coisas muito distantes da realidade dela. Trabalhando mais a realidade delas, as crianças assimilam bastante. Por exemplo, no acampamento você trabalhar o "b" de barraco, o "a" de acampamento, de assentamento. Partir da realidade é mais ou menos isso. Não que seja só isso, mas é essa base que eu tenho. A idéia é partir do palpável, do concreto, do que você está vendo. Assim a criança entende.

\footnotetext{
${ }^{334}$ Os livros de Paulo Freire são bibliografia obrigatória nos cursos de formação e parte integrante da proposta de educação do MST.

335 FREIRE, P. Pedagogia do oprimido. Rio de Janeiro: Paz e Terra, 1987, p.84/85.
} 
Mas Daniel vai além. Em sua entrevista fala de "tema gerador" e mostra que sua formação dá abertura para práticas pedagógicas flexiveis:

Hoje, com as crianças, a gente inventa. No meu acampamento tem uma roça de milho, a gente faz boneco de milho, faz colagem. Aprende a fazer brinquedo das coisas que estão ali nos Tempos-Oficina. Se alguma criança tem alguma experiência, alguma coisa para mostrar, tem que deixar ela ser educadora.

Tais idéias aparecem de forma mais teorizada na narrativa de Elizandra, quando apresenta:

Gosto muito do trabalho que faço dentro do Movimento, porque é em busca, como diz Paulo Freire, de uma educação libertadora. Uma educação diferente desse modelo educacional da nossa sociedade. É nas escolas da cidade que querem colocar as crianças do campo, não respeitando as diferenças, a identidade do povo camponês. É um grande desafio para nós.

Esse desafio foi proposto aos movimentos sociais por Freire, a medida que defendia que:

Este ensinamento e este aprendizado têm de partir, porém, dos "condenados da terra", dos oprimidos, dos esfarrapados do mundo e dos que com eles realmente se solidarizem. Lutando pela restauração de sua humanidade estarão, sejam homens ou povos, tentando a restauração da generosidade verdadeira.

Quem, melhor que os oprimidos, se encontrará preparado para entender o significado terrivel de uma sociedade opressora? Quem sentirá, melhor que eles, os efeitos da opressão? Quem, mais que eles, para ir compreendendo a necessidade da libertação? Libertação a que não chegarão pelo acaso, mas pela práxis de sua busca; pelo conhecimento e reconhecimento da necessidade de lutar por ela. ${ }^{336}$

$\mathrm{Na}$ busca desta "nova" educação o Movimento se impôs a tarefa de além de organizar os cursos de formação, produzir materiais

\footnotetext{
${ }^{336}$ Idem, p.31.
} 
didáticos que pudessem ser neles usados. Assim há uma grande produção de cartilhas, boletins, cadernos e revistas.

Outro material também usado pelos cursos, embora muitas vezes não tenham sido feitos para essa finalidade, são os filmes sobre o MST, elaborados por seus membros ou por pessoas ligadas ao Movimento. Os vídeos provocam, emocionam, chocam, questionam, mostram imagens alternativas ao universo midiático e estão presentes nas narrativas em momentos políticos, educativos e culturais importantes narrados pelos sem-terra, compondo universos subjetivos e identitários complexos, diversos e difíceis de serem reduzidos a esquemas de análises de ação coletiva tradicionais da sociologia ou da ciência política. Ao contrário, nos aproximam dos questionamentos sobre a polifonia das narrativas, a multiplicidade das subjetividades, e a presença constante da defesa da transmissão da experiência humana como forma de vivenciar na memória e na identidade individual e coletiva os processos de resistência, na contramão do contexto de destruição da experiência do contexto histórico atual.

Nessa medida resistência torna-se palavra importante. Resistir é um exercício diário que se estabelece com a sociedade (por seu modo vida), com o governo (em negociações), com a cultura (fazendo com que os hábitos camponeses não morram) e com o próprio corpo (quando não se tem comida suficiente, ou um lugar para se abrigar do frio e da chuva como ocorre nos acampamentos).

A identidade nesse sentido se caracteriza nas palavras de Castells como identidade de resistência, ao mesmo tempo em que inicia a organização de uma identidade de projeto ao propor significados e atuações visando uma mudança estrutural.

É importante destacar o avanço que significam esses cursos de formação para uma população que tradicionalmente foi condenada ao analfabetismo ou à baixa escolarização. Evidentemente, não estou anulando todo um processo de disseminação da educação pública no país. Mas de acordo com as estatísticas nacionais, o campo brasileiro ainda é o local em que as pessoas têm menor escolarização. Assim, há 
uma grande diferença entre as narrativas dos educadores já citados anteriormente e formados nos cursos do MST, se comparados com a geração de seu Luis, por exemplo:

Aprendi a escrever com 14 anos. Não sabia nada, fui morar na fazenda não tinha professor e meu pai foi me ensinando a conhecer as letras, "a", "b", isso aí. Depois que conheci as letras, eu peguei a juntar elas para fazer nome. Comecei assim... Nunca tive um dia de professor, numa escola. Eu tinha vontade, mas naquele tempo, as crianças não tinham isso. Quando nós viemos para São Paulo, que começou a estudar um pouquinho, aprender os nomes. Tinha uma vontade de ir na escola, mas miou... A escola nossa, na roça, é trabalhar, é enxada, é foice, é machado, o que fosse. De tudo eu fui, eu faço de tudo.

A escola da roça ainda é realidade para grande parte das crianças e dos jovens do campo, o que mostra um caminho longo a ser trilhado pelo Estado e por militantes do movimento social em busca da mudança deste quadro.

Marcha, um ritual místico

Por fim, gostaria de me deter e falar um pouco das marchas, que são concomitantemente momentos de místicas e de preparações para novas manifestações.

Fazer parte de uma manifestação como a marcha é ao mesmo tempo uma ação: instrumental, pois os sem-terra querem mudar sua circunstância, seu presente; identitária, pois querem agir como membros de um grupo; mas é também ideológica, pois querem expressar suas visões e sentimentos.

De qualquer forma investe-se no caminho da interpretação da marcha como uma forma de viver místico, um ritual, pensando nela como uma "suspensão do cotidiano", uma renovação de "votos", aproximando-a de celebrações de cunho religioso e tradicional, ao mesmo tempo em que se destaca seu teor político e formador. Um pouco a síntese do que penso ser parte da identidade "Sem Terra", ao 
mesmo tempo tradicional, mística, "religiosa", revolucionária, contestadora e política.

Um pouco dessa religiosidade pode ser vista nas seguintes palavras de Seu Luis:

Então, como estava dizendo, acho muito importante marchar. Porque, se não é com marcha, ninguém faz nada. Vejo falar das marchas que Moisés fez, porque lutou 40 anos para poder pegar uma terra. E a primeira marcha que teve foi no tempo de Abraão que ele saiu de Canaã, procurando chão. Desde aquele tempo que era para ter reforma agrária. Antes, quando Deus fez o mundo, não vendeu a terra para ninguém. As terras foram dadas para o povo trabalhar, para comer, para viver. É isso aí. Essa marcha é importante por causa disso também, porque naquele tempo, 40 anos eles marcharam para ter terra.

Wanderléia, ao contar que seu acampamento foi nomeado "terra prometida", lembra também o peso dessa religiosidade. A referência ao (com)partilhar vem às vezes envolta em um modo de se expressar religioso, do repartir o pão. Ela faz isso quando conta de seu casamento, quando se refere às carências enfrentadas nos dias da marcha, ou ao falar de seus companheiros e a vida no acampamento.

O ritual como sistema cultural de comunicação simbólica é ordenado e padronizado por meio de palavras e atos. Segundo Peirano ele é "performativo" por três motivos:

1 - no sentido pelo qual dizer é também fazer alguma coisa como ato convencional (como quando se diz "sim" à pergunta do padre em um casamento);

2 - no sentido pelo qual os participantes experimentam intensamente uma performance que utiliza vários meios de comunicação (um exemplo seria nosso carnaval); e 3 - finalmente, no sentido de valores sendo inferidos e criados pelos atores durante a performance [por exemplo, quando identificamos como "Brasil" o time de futebol campeão do mundo]. ${ }^{337}$

Adaptando para o presente trabalho a Marcha dos Sem Terra é uma ação ritual performativa nos três sentidos. No sentido de dizer/fazer, pois os marchantes se diziam sem terra e faziam a marcha.

${ }^{337}$ PEIRANO, Op. Cit., p.11. 
No sentido de experimentar a performance, eles estavam sentindo as dores da caminhada e celebrando a chegada em cada acampamento, diariamente. Recebiam jornalistas, davam entrevistas e buscavam seus rostos ou depoimentos nas cenas da televisão, nas vozes do rádio ou nas páginas do jornal. Por fim é também ritual no sentido dos valores, pela disciplina criada, de levantar cedo todos os dias, não atrasar a marcha, não formar buracos nas fileiras, e ao fazerem tudo isso por se identificarem enquanto Sem Terra.

Para definir o ritual da marcha é preciso fazer uma descrição dos "repertórios de eventos", das palavras e atos, mas também das roupas, diálogos, músicas, local dos acampamentos, estrutura de dormitório e estrutura sanitária e estrutura de comércio ambulante não organizado pelo Movimento - que se montava em todas as paradas da marcha.

A análise do ritual pode ajudar a entender formas de sociabilidade. Segundo Glukman, citado por Peirano, por meio do ritual é possivel ter acesso ao exame das estruturas sociais, exatamente por acreditar que ele conduzia a uma forma bastante particular para a resolução de conflitos. Turner, por sua vez, recuperou a noção de ritual de passagem, estabelecendo relações com os estados mentais, afetivos, sentimentais e estados de ser, considerando-os como criações culturais. Em seguida, Lévi-Strauss influenciado pela lingüística de Saussure e Jakobson, elaborou a teoria de que o mito é superior ao rito, por conter uma grande afinidade com a lingua. Assim na discussão entre LéviStraus e Turner diferencia-se o mito e o rito, o pensar e o viver, o dito e o feito.

Também são vistas as proposições de Leach que define com mais detalhe o aspecto ritual da comunicação, considerando também aspectos rotineiros e culturais como o aperto de mão como etiqueta ou cerimonial e, portanto, ato ritualístico. É nesse contexto que surgem os pensamentos de Tambiah que unem ritos e mitos estabelecendo que:

... eram bons para pensar e para viver [...] é assim que ele introduz a idéia de ação performativa: um atributo intrínseco 
tanto à ação quanto à fala, que permite comunicar, fazer, modificar, transformar. 338

O sem-terra que participa de uma mística, de uma marcha, e que vivencia essas experiências não é apenas um homem ou uma mulher que têm uma maior sociabilidade, ou entende melhor o Movimento, é um homem que está construindo, a cada passo, um mundo diferente. Nos acampamentos na beira das estradas esse mundo assumia uma concretude incontestável. Todos dormiam juntos, nas mesmas condições. Alimentavam-se da mesma comida. Passavam pelos mesmos problemas. Viviam as mesmas alegrias. E no dia seguinte depois de acordarem na mesma hora, caminhavam pela mesma estrada.

Nada ali era utópico. Aqueles dias eram realmente diferentes de tudo e a sociedade almejada se tornara muito real. Portanto os rituais fazem com que a sociedade tome "consciência de si, se crie e se afirme" 339 . Assim o ritual é ao mesmo tempo criador e recriador de valores que, ao serem partilhados por todo um grupo, assumem uma conotação mística, que não diz respeito aos deuses ou ao sobrenatural, mas sim às identidades do grupo.

Rituais e representações são tão determinantes da vida em sociedade que, muitas vezes, exigem que os individuos dêem sua própria vida para defendê-los, como, por exemplo em casos de guerra. Mas também estão presentes em grandes festividades como demonstrações populares. ${ }^{340}$

Dessa maneira, segundo a análise de Peirano, rituais não são fins em si mesmos, podem ser vistos como portas de entrada para o entendimento da sociedade brasileira, além de adequados para um exame das ambigüidades e dilemas que a permeiam.

A marcha política como ritual já foi objeto de estudo para Christine de Alencar Chaves. ${ }^{341}$ A Marcha Nacional por Reforma Agrária Emprego e Justiça organizada pelo MST em 1997 foi interpretada por essa antropóloga como um "ritual de longa duração". As marchas,

\footnotetext{
${ }^{338}$ Idem, p.39.

339 Idem, p.18.

${ }^{340}$ Idem, p. 19.

${ }^{341}$ CHAVES, Op. cit.
} 
embora não inseridas em um calendário do Movimento, têm se tornado uma forma de reivindicação que já se organizou nacionalmente em três diferentes ocasiões. Em 1997, houve o formato analisado em Vozes da marcha pela Terra, e em A marcha nacional dos sem-terra: um estudo sobre a fabricação do social ${ }^{342}$, em 1999, sobre a idéia da consulta popular, organizou-se uma nova marcha para Brasília. Recentemente, em 2005, o modelo volta a ser utilizado, mas agora massificado e inteiramente organizado pelo MST.

Chaves, assim como Löwy, ressalta as ligações entre religiosidade e política, presentes no MST. A marcha é exemplo da coerência dessa proposta, pois ao retomar as tradições das romarias, caminhadas e peregrinações, transforma seu fim, que passa a ser politico. Chaves escreveu sobre a marcha de 1997:

No ato de encerramento, formalmente dividido em três momentos - culto ecumênico, ato político, show artístico - as distinções não se mantiveram assim tão nítidas. Embora preservando características próprias, cada um dos momentos guardou elementos dos demais. Neles, categorias e símbolos apresentaram uma incomum transitividade, constituindo, na mistura, uma consagração da Marcha Nacional e dos significados por ela produzidos. A sucessiva dignificação da Marcha e de seus ideais promovida por diferentes atores terminava não só por conferir-lhe validação como por produzir, entre os proponentes dessa legitimação, uma aparente unidade. Sua manifesta diversidade foi subsumida, ao modo da multiplicidade que compôs o próprio ato e foi por ele englobada. No ato de encerramento da Marcha Nacional, o sangue e a cruz converteram-se em simbolos-mestres, portadores de diferentes significados, com ressonâncias simultaneamente religiosas, politicas e estéticas. Eles eram, a um tempo e sem contradição: morte e vida, martírio e renovação, sacrificio e ressurreição. ${ }^{343}$

Por meio da marcha do MST é possivel reconhecer elementos fundamentais do repertório político do campo brasileiro: as peregrinações. Elas indicam a legitimidade social do vínculo entre política e religião no país. Em outras palavras, o ritual mostrou-se uma

\footnotetext{
${ }^{342}$ RIBEIRO, MEIHY e SANTOS Op. Cit. e CHAVES, Op. Cit.

${ }^{343}$ CHAVES, Op. Cit., p.361.
} 
porta heurística, pela qual se pôde vislumbrar aspectos identitários de uma comunidade que dificilmente se manifestariam de outra forma.

Assim, para pensar a participação e atuação dos membros do MST como processos de consolidação identitária foi preciso refletir sobre a simbologia e sobre a mística adotada pelo Movimento, que aparecem de forma marcante nas manifestações dos sem-terra.

Ao se pensar a participação dos sem-terra no Movimento, foi interessante ver que isso implica na vivência de situações de exclusão, bastante dificeis. Acampamentos, ocupações e despejos são paradoxos vividos cotidianamente, já que quando uma pessoa entra no MST ela tem a intenção de mudar de vida, de ser incluída. Entretanto o processo de luta é longo e o ingresso nas fileiras do Movimento não garante a inclusão social imediata dessas pessoas.

Por isso é necessário que o desejo de se manter no grupo seja alimentado para que o vínculo com o Movimento seja mantido. Para isso foi feito um percurso de reflexão sobre as místicas, tanto como meios que possibilitam uma renovação desses "votos", como também como algo que se funda em uma tradição camponesa e se propõe a uma modificação das estruturas sócio-políticas atuais, tanto como denúncia, quanto como forma de reflexão sobre questões do presente.

Além da mística acredita-se que os processos educativos organizados pelo MST também são formas bastante fortes de organização identitária. Como apontei em um dos sub-títulos desse capítulo, a educação é uma bandeira de luta, não só porque é um "símbolo" que une pessoas, mas por ser algo pelo que se luta, por acreditar que por meio dela pode-se mudar estruturas sociais e superar a exclusão.

Manifestações como as marchas são momentos em que tudo isso se encontra. Por isso foram vistas como rituais, em que se celebram, se reforçam e se recriam identidades, portanto foram vistas também como momentos de mística. 


\section{Caminhos pessoais, marchas coletivas}

Viver no início de um novo século e de um novo milênio provoca inquietações a respeito do que se foi, do que se é e do que se deseja ser, por isso a questão da identidade, seja como experiência, memória ou narrativa, aparece revigorada, já que o contexto atual pede e dá passagem às discussões que remetem à busca de sentidos e significados para a existência. A identidade se impôs como uma questão do presente, e por isso foi tratada como tema central de um trabalho sobre a história do tempo presente.

Nesta pesquisa, tratou-se da questão da identidade, pois tanto dentro quanto fora da academia, essa questão vem se delineando como algo central. A importância de se produzir identidades repousa, dentre outras coisas, no fato de as identidades terem como tarefa promover a inclusão social de um grupo específico, no caso estudado, isso ocorre de maneira patente. Existe um debate e uma disputa em torno das questões de identidade e isso não é menos relevante dentro do Movimento Sem Terra.

A preocupação central deste trabalho foi estudar identidades sem-terra e seus processos de construção, que vêm se desenhando e que permanecem em constante movimento. Entretanto, é preciso evidenciar que as tramas biográficas registradas funcionaram como mais uma forma de consolidação de identidades, colocando em questão as identidades subjetivas e a constituição do sujeito através da narração. Assim, no processo de produção dessa tese, ao mesmo tempo em que se falava e narrava processos de formação de identidades, ao mesmo tempo em que elas foram estudadas, elas foram também 
construídas. A história oral ganhou sentido quando pensada como um novo olhar sobre a sociedade, que pode responder às demandas da realidade direta de quem vivencia situações de exclusão no mundo contemporâneo, pois valoriza a subjetividade e as tramas da narrativa. Esse trabalho, portanto, deve ser entendido em um movimento maior, como sendo resultado de uma virada teórica e ideológica que vem ocorrendo nas humanidades, chamada por alguns de "guinada subjetiva", que procura partilhar valores e partir da experiência dos sujeitos para a construção do conhecimento.

As narrativas deixam claro a urgência do debate sobre identidade, assim como mostram as maneiras como elas se constroem e se reconstroem. Não existe identidade sem memória. Esses sujeitos contam a história de como passaram a ser o que são hoje e como vêem a si próprios, ao narrarem, naquele momento específico - literalmente no meio do caminho - suas marchas de vida e seus processos de identificação com o MST. Identidades forjaram-se com base em vivências e existências e se consolidam tanto como tarefa, quanto como projeto. Formam-se identidades individuais e coletivas, múltiplas e contraditórias, que atravessam as experiências de estar no mundo de modos bastante particulares.

O processo histórico é contínuo, mas não linear. Possui idas e vindas, desvios, avanços e recuos, inversões. As tramas, que possuem diversos pontos e laços possiveis (sem uma linearidade préestabelecida), são exemplos de como o modo de contar uma história influencia aquilo que foi, é e será contado. Fatos presentes acabam por re-significar o passado e, consequentemente, modificar o presente e o futuro, embora este seja, é claro, sempre incerto e impreciso.

Não se nega que os acontecimentos narrados possuem relação com os fatos passados. Pelo contrário, muitas vezes essas narrações trazem à tona ligações, justificando que as rupturas de uma história de vida não acontecem de repente, sem explicação. Dentro da construção narrativa confere-se ordem aos caminhos e mesmo sentidos à trajetória percorrida no presente. As mudanças não se dão por mero acaso, 
resultam de uma linearidade interna a um indivíduo ou um grupo, que pode ser caracterizada como contingência para alguém que não tem contato com seu modo de ler o mundo,. Assim a contingência histórica pode ser lida como fundamento de estratégias legitimadoras e emancipatórias de confrontos.

O texto dessa tese foi escrito de acordo com as linhas expostas nos caminhos percorridos pela pesquisadora e pelos entrevistados. $\mathrm{Na}$ primeira parte, foram apresentadas as tramas biográficas dos colaboradores e uma narrativa produzida a partir da experiência de pesquisa, uma reflexão particular sobre o que foi feito, na medida em que se propôs uma história do projeto, e um balanço da experiência de pesquisa. Essa organização inicial foi pensada pois, como apresentado no capitulo seguinte, as memórias narradas têm como base a experiência vivida. Assim, experiência, memória e narrativa foram conceitos trabalhados para que se pudesse fazer um balanço da própria produção de documentação em história oral.

Evidentemente, experiência é conceito chave para a constituição de identidades, e por isso experiência e identidade foram temas trabalhados na segunda parte desta tese. A partir da idéia de que a experiência de exclusão é fundamental para se entender a construção das identidades sem-terra, o texto aborda temas "tramados" pelas narrativas, assim como procura mapear as questões teóricas a eles ligadas. Durante todo o percurso, sempre o olhar para as reflexões elaboradas foi dimensionado a partir da leitura das narrativas, e é por isso que a primeira parte do trabalho apresenta as histórias de vida e cada capítulo inicia-se com pequenas citações de frases extraídas dos textos produzidos a partir das entrevistas com os colaboradores. Frases que ecoaram durante todo o tempo de pesquisa.

Ao se falar em exclusão e formas de inclusão, refletiu-se também sobre a questão da cidadania e da democracia, por estas significarem a inclusão do sujeito no mundo político, e serem e possibilitarem formas de luta e possibilidades de superação da exclusão. Marca concreta dessa inclusão, para os narradores, é a 
diferença da vida antes e depois de conhecerem o Movimento Sem Terra.

A busca pela inclusão resulta na procura em "ser alguém", "ter algo" e em fazer parte de uma comunidade. A comunidade encontrada foi o MST, e por isso o que marca a possibilidade de superação da exclusão é a entrada no Movimento. Essa problemática conduz à reflexão mais detida sobre o movimento social como mediador de um processo de identificação para seus membros, que de acordo com suas próprias subjetividades e necessidades passam a vê-lo de maneira particularizada. Isso produz um caleidoscópio de identidades que se modificam no caminho, ao mesmo tempo em que, estando lado a lado, se complementam num desenho único e cheio de vida.

Frente a essa diversidade, afirma-se que existem muitos movimentos, mas não se pensa que não exista um MST. Apenas é preciso lembrar que ele não é igual para todos. Sendo o Movimento interpretado e entendido de formas tão plurais e diversas por seus componentes, propõe-se que não existe uma identidade "Sem Terra" única, como querem alguns de seus pensadores, mas sim identidades que compõem o Movimento Sem Terra, em sua diversidade. Ao escrever isso, reforça-se uma crítica à construção monolitica de uma identidade que, em seu limite, pode não ser sentida por ninguém. Propomos que essa identidade monolitica dê lugar a expressões e subjetividades que são sempre plurais.

A formação identitária oficial é apresentada nas narrativas pelo envolvimento mais efetivo com o MST. A participação e atuação são elementos fundamentais para a construção das identidades sem-terra. Para tanto, foi preciso pensar um pouco sobre os símbolos escolhidos e rituais realizados pelos sem-terra enquanto grupo. Deu-se atenção especial às místicas, pois a documentação utilizada pelo trabalho em sua maioria foi registrada durante a grande mística que foi a marcha.

Concomitantemente, evidenciaram-se paradoxos, e desconstruíram-se idealizações em torno das experiências dos acampamentos e das ocupações. Por se acreditar que a atuação 
educativa e formativa desenvolvida pelo MST tem um importante papel no processo de identificação, tratou-se com destaque as conquistas da educação apontadas pelas entrevistas.

Desta forma, o trabalho propôs uma discussão em duas direções. A primeira, sobre as construções identitárias que envolvem o MST. Outra, a respeito da aplicação da história oral como forma de produção e análise da documentação produzida por essa pesquisa. Os assuntos foram tratados conjuntamente, mesmo porque, muitas vezes, a reflexão sobre a metodologia envolveu a análise do tema, e vice-versa. Assim, teoria e trabalho de campo, de maneira geral, não foram tratados separadamente, mas de maneira a estabelecer sentidos entre ambos.

Não posso descolar o sujeito que me tornei do tipo de história que quero fazer. Ao mesmo tempo, é necessário pensar sobre o ato de constituição dos sujeitos nessa pesquisa e o quanto isso me influenciou. Afirmar isso não implica em dizer que sou um dos semterra. Tenho outra vivência, pois também me formei em meio aos diálogos acadêmicos e de minhas tradições familiares. Essas outras experiências permitem ver de uma outra forma a vida dessas pessoas. Mas de qualquer maneira tentei sempre manter em mente que é possivel o saber histórico e o engajamento político “alimentarem-se mutuamente".

O diálogo entre produção de conhecimento e posicionamento político também se fez presente na constituição das histórias de vida transcriadas, pois elas resultam da interação entre intenções dos colaboradores e da pesquisadora. Intenções que se colocavam em negociação no momento da entrevista, à medida que se apresentavam concepções diferenciadas de produção de conhecimento e luta política.

Durante esse tempo dedicado à pesquisa foi possivel acompanhar algumas mudanças internas no grupo dos sem-terra, motivadas por muitos fatores, entre eles, e nada despreziveis, as mudanças da sociedade brasileira e do mundo, frente aos avanços dos processos de globalização. Boa parte delas foi incorporada pelas 
narrativas sem que se evidenciasse uma ruptura. Não porque se quer esconder algo, mas porque para o olhar dos que vivenciam o cotidiano do Movimento, não houve ruptura.

As mudanças integram o processo. Elas também aconteceram na própria pesquisa e em como achava ser "o melhor modo" de apresentar os resultados desse trabalho. Hoje, não é possível defender que exista uma forma definitiva para tal tarefa. Antes mesmo de acabar esse texto outras formas melhores poderão surgir e certamente durante sua elaboração, a estrutura do trabalho mudou várias vezes.

Tendo isso em mente, nesse trabalho a identidade sem-terra foi vista como algo múltiplo. Para tanto, foram evidenciadas contradições, ambigüidades e paradoxos e procurou-se mostrar como a identidade "central" formada por algumas lideranças do Movimento se descentra.

Dizer isso não invalida ou desvaloriza a entrada no movimento social. Sinalizou-se o quanto fazer parte do MST é importante para essas pessoas, representando diferenças concretas em suas vidas. Isso significou sim uma virada. No entanto, ela não deve ser vista como redentora. Pode-se apontar que, se por um lado, a (re)conquista da cidadania acontece, por outro ela é limitada, há muito por fazer.

$\mathrm{Na}$ interpretação das narrativas percebeu-se uma separação entre público e privado. Ou seja, a vida privada não está exposta para a maioria dos colaboradores, ela apareceu algumas vezes, motivada por perguntas. No entanto, o que se deve notar é que a vida familiar/privada, de modo geral, não faz parte dessas entrevistas, que têm um caráter mais militante/profissional. Pode-se explicar isso pelo lugar onde foram gravadas tais entrevistas - a marcha - o que sem dúvida ajudou a direcionar o conteúdo das narrações. Uma outra leitura possivel é que tais narrativas são assim, porque essas pessoas acreditam que a história que vale a pena ser contada não é a pessoal, mais subjetiva e provavelmente mais conflituosa, e sim a marcada pela experiência do grupo. Afinal foi o participar do grupo que a fez ser escolhida para narrar essa história. Dessa forma, pode-se pensar que 
existe um discurso "pronto" que justifica a militância, reforça o pertencimento ao MST e expõe uma identidade do grupo, em que particularidades como a família e os sentimentos aparecem apenas nas entrelinhas, quando aparecem.

É possivel perceber ainda um fascínio pela organização e pelo tamanho do Movimento. Assim, momentos como a marcha de 2005, que reuniu cerca de doze mil pessoas, são elementos fortes para a consolidação de uma identidade que se enxerga assumindo contornos e demarcando-se como coletiva, particular, organizada e independente.

É também importante pensar que a maioria das pessoas que estão em marcha tem um grau de identificação com o movimento, ao mesmo tempo em que estão construindo possibilidades e escolhendo suas identidades, ao participar desse ritual. Por isso, nas entrevistas, a identidade central aparece muito mais como sustentação que como cobrança. Quando são feitas críticas ao Movimento são críticas à forma de agir. Esse é o perfil das críticas apresentadas por Ronaldo com relação à forma com que desempenha seu trabalho e às cobranças que são feitas por parte de algumas pessoas do MST. Ou ainda, as apresentadas por Elizandra sobre o comportamento autoritário das pessoas em posição de mando dentro da estrutura do Movimento.

Há uma caracterização da identidade do MST por meio da atuação dos vários setores, em especial o Setor de Frente de Massas o Setor de Formação e o Setor de Educação. Isso permite a existência de um denominador comum que pode ser percebido na leitura do material de apoio ou didático produzido pelo Movimento. Mas esses materiais são assumidos com critérios diferentes, dependendo das tradições individuais e das subjetividades envolvidas. Sem descaracterizar a diferença, no MST, pode haver espaços para reorganizações identitárias a partir das releituras da identidade central.

É no cotidiano interno do MST que acontecem negociações e se estabelecem novas identidades. Novas diferenças aparecem e assim novas identidades se formam. Em meio a essas mudanças, a identidade oficial, que se pretendia sólida, vai sendo liquefeita. As especificidades 
de gênero, raça, religião, idade e origem aparecem com força suficiente para mudar, ou ao menos abalar, "a identidade Sem Terra".

Assim delinea-se "identidade Sem Terra" como aquela "pretensamente" una, definida pela liderança do MST, e "identidades sem-terra" como as construídas por seus membros, que ora complementam, ora se contrapõem à primeira. O interessante é mostrar que essas identidades não são estanques, e constantemente se modificam. Por isso o Movimento não pode ser visto como algo congelado, mas sim como um corpo vivo que muda e marcha.

Há momentos em que o processo de identificação, que atinge a todos - lideranças ou não - convive com um conjunto de dúvidas e questionamentos, de modo que a identidade oficial é redimensionada, fragmentada ou liquefeita. Essa fragmentação apareceu, para a pesquisa, justamente em uma das ocasiões que foram pensadas como identificadoras e unificadoras: a marcha organizada pelo MST. O exemplo mais claro disso é que as entrevistas gravadas em pleno ritual místico da marcha apresentaram contradições e embates que a negociação identitária impõe. Evidenciam-se os conflitos de gênero, raça, poder, nível educacional, dentre outros.

Assim, ser mulher e ser homem no MST são coisas bastante diferentes. Há ainda uma estrutura machista, que faz com que a participação feminina da direção nacional às fileiras da marcha seja minoritária. Ser negro, ser índigena e ser branco também implica em diferenciações, que trazem à tona o debate sobre a colonização e sobre a escravidão. A retomada desses temas marca um discurso que questiona quem são os verdadeiros donos da terra e posiciona os sem-terra como herdeiros de lutas de líderes como Zumbi dos Palmares. A educação se apresenta como algo importante, a busca pelo fim do analfabetismo e a luta pelo aumento e pela melhoria da escolarização de seus integrantes são bandeiras para a superação de uma situação de exclusão histórica. Além dos custos que isso impõe à vida, no Movimento, ser escolarizado ou não, representa uma grande diferença, e a educação é marco de certa hierarquia. 
Apontados tais conflitos, nota-se que este trabalho enfrentou um problema comum a diversas pesquisas que utilizam entrevistas, sobretudo de história de vida. Nas gravações recolhem-se memórias individuais, ou no caso de entrevistas de grupo, memórias que se referem a uma vivência um pouco mais coletiva. $O$ problema resultante dessa operação é saber como interpretar o material, alertando que os pesquisadores deveriam preocupar-se menos com a "factualidade positivista" e mais com as "percepções da realidade".

A proposta da leitura, portanto, foi apresentar os pontos que levaram a refletir sobre a questão da identidade. A leitura que foi feita também procurou entender a construção das histórias desses narradores, suas escolhas, razões e motivos. Evidentemente, apresentaram-se aqui apenas algumas dentre as muitas interpretações que o texto motivado por esse encontro pode gerar. E tais interpretações foram exploradas enquanto possibilidade.

O MST é apresentado como possivel elemento de coesão, e nas palavras da história oral, pode ser considerado a comunidade de destino. Essas pessoas buscam algo em comum, vêem a luta pela terra como meio de conquista de sua cidadania. É também a comunidade afetiva, por ser em torno da idéia de ser sem-terra que pessoas de várias origens se sentem semelhantes e ligadas. $O$ fato concreto de ter conquistado terra, muitas vezes, não afasta essas pessoas do MST, pois como seus membros costumam dizer "enquanto houver um sem-terra, todos são sem-terra". Assim, o afeto e o objetivo comum ligam as pessoas entrevistadas tornando-as membros dessa comunidade.

Ser membro de uma comunidade implica em compartilhar memórias que formam uma memória coletiva. Nesse sentido, a memória compartilhada pelo grupo estudado é da exclusão. Alguns trabalhos que analisam traumas políticos e sociais clássicos, como as ditaduras ou o holocausto, selecionam situações localizadas, datadas historicamente e aparentemente findas. Ou seja, esses são eventos que ocorreram dentro de um espaço e de um tempo, passado e por isso podem ser delineados, mesmo que os traumas por eles gerados não tenham sido resolvidos, e 
seus mortos ainda não enterrados. O estudo da exclusão como trauma, proposto por essa tese, deparou-se com uma situação que está em processo. Tanto as situações geradoras do trauma da exclusão, quanto seus efeitos não cessaram, e mesmo com alternativas sendo propostas, dificilmente podem-se imaginar, no cenário atual, seu fim próximo.

O século XX já foi interpretado como um é um século de traumas, e a própria modernidade, desde Benjamin, é vista como traumática, por anular a possibilidade de experiência narrável. A exclusão, sistêmica moderna, é traumática e suas fronteiras não podem ser definidas em termos precisos. Dentro desse caminho, há, no entanto, eventos que podem ser claramente demarcados como as muitas chacinas de trabalhadores rurais, dentre as quais podemos citar com destaque o Massacre de Eldorado dos Carajás, ocasião em que foram mortos 19 membros do Movimento dos Trabalhadores Rurais Sem Terra.

De forma geral, o que interessa é pensar na exclusão vivida pelos sem-terra como uma herança histórica experienciada coletiva e individualmente e apreendida de forma pessoal, subjetiva, mas que a partir do ingresso no Movimento passa a ser compreendida como um problema político e não individual. Sua tomada de consciência também não é sincrônica. As pessoas ao encontrarem uma comunidade, estabelecem diálogos, constroem identidades, relembrando e elaborando novos sentidos a essas experiências. Dessa forma, esse é um importante passo no caminho para a elaboração de alternativas para o enfrentamento do problema.

Conclui-se que existe uma identidade central ou oficial do Movimento, marcada pela diferença, que se define a partir do trauma da vivência de exclusão. O fato de não ter terra - que significa, entre outras coisas, não ter como viver uma vida plena, em sentido material (da manutenção e reprodução da força de trabalho), e simbólico (da vivência de desejos, sonhos e crenças) - aglutina as pessoas em volta de uma bandeira, que representa o Movimento. Em um primeiro instante uma identidade é definida como norte, para onde se caminhar. 
Paralelamente, existem identidades, múltiplas e subjetivas, que marchando nas mesmas fileiras, escolhem sentidos e propõem novos caminhos. 


\section{Bibliografia}

ADES, César. A memória partilhada. Resenha de Bosi, Ecléa. O Tempo Vivo da Memória: ensaios de Psicologia Social. Disponivel em: http://www.scielo.br/pdf/pusp/v15n3/24613.pdf, acessado em 11/01/07.

AGAMBEM, G. Homo sacer: o poder soberano e a vida nua I. Belo Horizonte: Ed. UFMG, 2002.

AGAMBEN, Giorgio. Infância e história: destruição da experiência $e$ origem da história. Belo Horizonte: Editora UFMG, 2005.

ALCÂNTARA, M; JUSTOS, M. O Movimento dos Sem Terra : uma análise sobre o discurso religioso, in Revista imaginário. Disponivel em:

http://www.imaginario.com.br/artigo/a0061_a0090/a0064.sht ml. Acessado em dezembro de 2006.

ANDERSON, Benedict R. Imagined communities: reflections on the origin and spread of nationalism. London; New York: Verso, 1991.

ANDRADE, Maristela de Paula. Chacinas e massacres no campo. (Coleção Célia Maria Corrêa - Direito e Campesinato, nº 4) São Luís: Universidade Federal do Maranhão, 1997.

ARENDT, Hannah. Entre o passado e o futuro. São Paulo: Perspectiva, 1979.

ATAÍDE, Yara Dulce Bandeira. Decifra-me ou te Devoro, História Oral dos Meninos de Rua de Salvador. São Paulo: Ed. Loyola, 1993.

AUGÉ, Marc. Não-lugares: introdução a uma antropologia da supermodernidade. Campinas/SP: Papirus, 1994.

AZZAN JR, Celso. Antropologia e interpretação: explicação $e$ compreensão nas antropologias de Lévi-Strauss e Geertz. Campinas: Ed. Unicamp, 1993.

BAKHTIN, Mikhail. Os gêneros do discurso. In: Estética da Criação Verbal. 2a. ed., São Paulo: Martins Fontes, 1997, pp. 279-326.

BARBOSA, Márcio Ferreira. Experiência e narrativa. Salvador: EDUFBA, 2003.

BARNET, Miguel. Memórias de um Cimarron: testemunho. São Paulo: Marco Zero, 1986.

BARROS, José D'Assunção. O campo da história: especialidade e abordagens. Petrópolis, RJ: Vozes, 2004.

BARTES, Rolan. Análise estrutural da narrativa. Petrópolis: Vozes, 1976.

BAUMAN, Zygmunt. Modernidade liquida. Rio de Janeiro: Jorge Zahar Editor, 2001. - Comunidade: a busca por segurança no mundo atual. Rio de Janeiro: Jorge Zahar Editor, 2003. . Identidade. Rio de Janeiro: Jorge Zahar Editor, 2005a. 
- Vidas desperdiçadas. Rio de Janeiro: Jorge Zahar Ed. 2005b.

BENJAMIN, Walter. Walter Benjamin. Obras Escolhidas. Magia e

Técnica, Arte e Politica. São Paulo, Ed. Brasiliense, 1985.

BENKO, Georges. Economia, espaço e globalização na aurora do século XXI. São Paulo: Hucitec, 1996.

BERGER, Peter L. e LUCKMANN, Thomas - A construção social da realidade, Petrópolis, Vozes. 1966.

BÉRGSON, Henri. Matéria e memória: ensaio sobre a relação do corpo com o espírito. São Paulo: Martins Fontes, 1990.

BHABHA, Homi K. O local da cultura. Belo Horizonte: Ed. UFMG, 2001.

BLOCH, Marc. Apologia da História ou o oficio de historiador. Rio de Janeiro: Jorge Zahar ed., 2001.

BOFF, Leonardo. Igreja, carisma e poder. Petrópolis: Vozes, 1981. - Responder Florindo: da crise da civilização a uma revolução radicalmente humana. Rio de Janeiro: Garamond, 2004.

BOSI, Eclea. Memória e sociedade. Lembrança de velhos. São Paulo: Cia das Letras, 1994.

O tempo vivo da memória: ensaios de psicologia social. São Paulo: Ateliê Editorial, 2003.

BOURDIEU, Pierre. A miséria do mundo. Rio de Janeiro: Vozes, 1997.

BRANCO, Maria Teresa Castelo. Jovens sem-terra: identidades em movimento. Curitiba: Ed. UFPR, 2003.

BRANDFORD, Sue e ROCHA, Jan. Rompendo a cerca: a história do MST. São Paulo: Casa Amarela, 2004.

BRESCIANI, Stella e NAXARA, Márcia (orgs.) Memória e (res)sentimento: indagações sobre uma questão sensivel.Campinas. Editora da Unicamp, 2001.

BRISON, Susan J. Aftermath: violence and the remaking of a self. Princeton, NJ: Princeton University Prress, 2003.

BRITO, Fábio Bezerra de. Ecos da Febem: história oral de vida de funcionários da Fundação Estadual de Bem-Estar do Menor de São Paulo. São Paulo: DH-FFLCH-USP, 2002.

BRUNER, E. M. Ethnography as narrative. IN: TURNER, V. W. and BRUNER, E. M. (org). The anthropology of experience. Chicago: University of Illinois Press, s/d.

BURGOS, Elisabeth. Me llamo Rigoberta Menchú y así me nació la conciência. Barcelona: Argos Vergara, 1983.

BURGUIĖRE, André (org). Dicionário das ciências históricas. São Paulo: Imago, 1993.

BURKE, Peter. A Escola dos Annalles, 1929-1989. A revolução francesa da historiografia. São Paulo: Unesp, 1991. (org). A escrita da história: novas perspectivas. São Paulo: Ed. UNESP, 1992.

. História e teoria social. São Paulo, Editora Unesp, 2002.

CAIRE-JABINET, Marie-Paule. Introdução à historiografia. Bauru/SP: Edusc, 2003.

CALDART, Roseli Salete. Educação em movimento: formação de educadoras e educadores no MST. Petrópolis/RJ: Vozes, 1997. 
- Pedagogia do Movimento Sem Terra: escola é mais do que escola. Petrópolis, RJ: Vozes, 2000.

CALDAS, Alberto de Lins. Oralidade, texto e história-Para ler a história oral. São Paulo, Ed. Loyola, 1997.

- Transcriação em história oral. In: Neho-história. No 1, novembro de 1999. pp. 71-79.

Nas águas do texto: palavra, experiência e leitura em história oral. Porto Velho: Edufro, 2001.

CALIARI, R. O. Pedaggia da Alternâncias e desenvolvimento local.

(Dissertação de Mestrado). Administração, Universidade Federal de Lavras, MG , 2002.

CANCLINI, N. G. Culturas híbridas, estratégicas para entrar e sair da modernidade. EDUSP, São Paulo. 1997.

CÂNDIDO, Antônio. Parceiros do rio bonito. São Paulo: Duas Cidades, 1987.

CARR, Edward Hallet. Que é História? São Paulo/Rio de Janeiro: Ed. Paz e Terra, 2002.

CASTELLS, Manuel. O poder da identidade. Coleção A Era da Informação: Economia, Sociedade e Cultura, Volume 2. São Paulo: Paz e Terra, 2006.

CASTORIADIS, Cornelius. As encruzilhadas do labirinto II. Os dominios do homem. s/d.

- Os intelectuais e a história. In: As encruzilhadas do labirinto 13. O mundo fragmentado. Rio de Janeiro: Paz e Terra, 1992.

CHARTIER, Roger. A beira da falésia, a história entre certezas e inquietude. Porto Alegre, ed. Universidade/UFRGS, 2002.

CHAUI, Marilena. Público, privado, despotismo. In: Novaes, A. (org.) Ética. São Paulo: Companhia das Letras, 1996, p.345 - 390.

CHAVES, Christine de A. A marcha nacional dos sem-terra: um estudo sobre a fabricação do social. Rio de Janeiro: Relume-Dumará, 2000.

CLIFFORD, James. The predicament of culture. Harvard: Harvard University Press, 1988.

COMPARATO, Bruno Konder. A ação politica do MST. São Paulo: Ed. Expressão Popular, 2003, p.27.

DAGNINO, Evelina. Os movimentos sociais e a emergência de uma nova noção de cidadania. In: Os anos 90: politica e sociedade no Brasil. São Paulo, Brasileiense, 1994.

DENZIN, Norman K. Interpretative Biography. Thousand Oaks, CA: Sage, 1989.

DERRIDA, Jacques e BENNINGTON, Geoffrey. Jacques Derrida. Rio de Janeiro: Jorge Zahar, 1996. . Gramatologia (1967). São Paulo: Perspectiva; Editora da USP, 1999. e ROUDINESCO, Elisabeth. De que amanhã... Diálogo. Rio de Janeiro: Jorge Zahar, 2004.

DIEHL, Astor Antonio. Cultura historiográfica. Memória, identidade e representação. Bauru/SP: EDUSC, 2002. 
DOSSE, François. A História em migalhas. São Paulo: Ed. Unicamp, 1989.

ELIAS, Norbert e SCOTSON, John L. Os estabelecidos e os outsiders. Sociologia das relaçõesde poder a partir de uma pequena comunidade. Rio de Janeiro: Jorge Zahar Ed, 2000.

ENDERS, Armelle. Les Lieux de Mémoire, dez anos depois. In : http://www.cpdoc.fgv.br/revista/arq/119.pdf, acessado em $11 / 01 / 07$.

FEBVRE, Lucien. Combates pela história. Lisboa: Ed. Presença, 1989.

FERNANDES, Bernardo M. MST - Formação e Territorialização. São Paulo: Hucitec, 1996.

. Brasil: 500 anos de luta pela terra. Mimeo, 1999.

FERREIRA, Marieta. M. e AMADO, Janaina. Usos e abusos da história Oral. Rio de Janeiro: Editora FGV, 1996. - Oralidade e memória em projetos testemunhais. In: LOPES, Antonio H, VELLOSO, Mônica P., PESAVENTO, Sandra J. (orgs) História e linguagens: texto, imagem, oralidade e representações. Rio de Janeiro, Edições Casa de Rui Barbosa e 7 Letras, 2006. . História, tempo presente e história oral. Disponivel em: http://www.ifcs.ufrj.br/ ppghis/pdf/topoi5a13.pdf, acessado em 28/05/07.

FONSECA, Claudia; BRITES, Jurema (Orgs.) Etnografias da participação. Santa Cruz do Sul: EDUNISC, 2006.

FORTUNA, Carlos. Cidade, cultura e globalização: estudos de sociologia. Disponivel em: www.ces.uc.pt/publicacoes/outras/199701/01introducao.php, acessado em 22/04/06.

FOUCAULT, Michel. As palavras e as coisas: uma arqueologia das ciências humanas. São Paulo: Martins Fontes, 1985. . A ordem do discurso. São Paulo: Ed. Loyola, 2004.

FRASER, Nancy. Rethinking the public sphere: a contribution to the critique of actually existing democracy. IN: Social Text, $\mathrm{n}^{\circ}$ 25/26. Durham, NC: Duke University Press, 1990, p 57.

FREIRE, Paulo. Pedagogia do oprimido. Rio de Janeiro: Paz e Terra, 1987.

FUKUYAMA, Francis. The End of History and the Last Man. New York: Free Press, 1992.

FURET, François. A oficina da História. Lisboa: Gradiva, 1991.

GARCEZ, Rodrigo. Guia fotocênico dos caracteres macuqueiros. Um estudo da metodologia de Bertolt Brecht aplicada ao universo poético de Plínio Marcos. Dissertação de Mestrado, ECA-USP, São Paulo. 2005. - Movimento no ar - Do kinokaos à lama. Trabalho de conclusão de curso, ECA-USP, São Paulo. 2001.

GEBAUER, G.; WULF, C. Mimesis: Culture, Art, Society. University of California Press, Berkeley. 1995.

GEERTZ, Clifford. A interpretação das culturas. Rio de Janeiro, Zahar Editores, 1989. 
- O saber local: novos ensaios em antropologia interpretativa. Rio de Janeiro (RJ): Vozes, 1997.

- Nova luz sobre a antropologia. Rio de Janeiro: Jorge Zahar, 2001.

- Obras e vidas: o antropólogo como autor. Rio de Janeiro: Ed. UFRJ, 2002.

GIDDENS, Anthony. As conseqüências da modernidade. São Paulo, Ed. UNESP, 1991.

. Modernidade e identidade. Rio de Janeiro: Ed. Jorge Zahar, 2002.

GOFFMANN, Erving. Estigma: notas sobre a manipulação da identidade deteriorada. Rio de Janeiro: Zahar, 1982.

GÖRGEN, Frei Sérgio. Os cristãos e a questão da terra. São Paulo: FTD, 1987.

. O massacre de Santa Elmira. Petrópolis: Vozes, 1989.

GRAZIANO Neto, Francisco. A tragédia da terra. São Paulo: Unesp, 1990.

. Qual reforma agrária? Terra, pobreza e cidadania. São Paulo: Geração Editorial, 1996.

GRELE, Ronald J. La Historia y sus Lenguajes en la Entrevista de Historia Oral: Quién Contesta a las Preguntas de Quién y Por Que? In: Historia y Fuente Oral, n 5, 1991, p. 111-115.

GROS, Frederic (org). Foucault: a coragem da verdade. São Paulo: Parábola Editorial, 2004.

HABERMAS, Jürgen. Citizenship and national identity. In: B. van Steenberg (org.) the condition of citizenship. London: Sage, 1994, pp.21 - 35.

HALBAWCS, Maurice. A memória coletiva. São Paulo: Vértice, 1990.

HALL, Stuart, at alli. Identidade e diferença: a perspectiva dos estudos culturais. Petrópolis: Vozes, 2004.

. A identidade cultural na pós modernidade. Rio de Janeiro: DP\&A, 2005.

HELLER, Agnes. O cotidiano e a história. Rio de Janeiro, Paz e Terra, 1985.

HOBSBAWM, Eric. Rebeldes primitivos. Estudos sobre formas arcaicas de movimentos sociais nos séculos XIX e XX. Rio de Janeiro: Zahar Editores, 1970. . Era dos Extremos. O breve século XX, 1914-1991. São Paulo, Cia. das Letras, 1996.

. Pessoas extraordinárias: resistência, rebelião e jazz. São Paulo: Paz e Terra, 1998.

HOOPES, James. Oral history: an introduction for students. Chapel Hill: The University of North Carolina Press, 1979.

HUNT, Lynn. A nova história cultural. São Paulo: Martins Fontes, 1992.

HUYSSEN, Andréas. Seduzidos pela memória: arquitetura, monumentos, midia. Rio de Janeiro: Aeroplano Editora, 2004.

IOKOI, Zilda M. Grícoli. As lutas camponesas no Rio Grande do Sul e a Formação do MST. In: Revista Brasileira de História 22, 
Estruturas agrárias e relações de poder. São Paulo: ANPUH, Marco Zero, mar/ago de 1991.

Igreja e camponeses. Teologia da libertação e movimentos sociais no campo, Brasil e Peru, 1964 - 1986. São Paulo: Hucitec/Fapesp, 1996.

e QUEIROZ, Tereza Aline P. de. A história do historiador. São Paulo: Humanitas, 2003.

JAMESON, Fredric. A cultura do dinheiro. Ensaios sobre a globalização. Petrópolis/RJ: Vozes, 2001.

JENKINS, Keith. A história repensada. São Paulo: Ed. Contexto, 2005.

LASCH, Christopher. A cultura do narcisismo: a vida americana numa era de esperanças em declínio. Rio de Janeiro; Imago Editora, 1983.

LE GOFF, Jaques e NORA, Pierre. História:Novas Abordagens; Novos Problemas; Novos Objetos. (3 vols.) Rio de Janeiro, Francisco Alves, 1988.

. História e memória. Campinas, SP: Ed. Unicamp, 1996.

LEACH, Edmund R. Once a knight is quite enough (sic): Como nasce um cavaleiro britânico. Mana, Abr. 2000, vol 6, n¹, pp. 31-56.

LEFEBVRE, Henri. La presencia y la ausencia: contribución a la teoria de las representaciones. México: Fondo de Cultura Económica, s/d.

LEFEBVRE, Henry. A Vida Cotidiana no Mundo Moderno. São Paulo, Ed. Ática, 1991.

LESSER, Jefrey. A negociação da identidade nacional: imigrantes minorias e a luta pela etnicidade no Brasil. São Paulo: Editora UNESP, 2001.

LÉVI-STRAUSS, Claude. As estruturas elementares do parentesco. São Paulo: Edusp, 1976.

. O Pensamento selvagem. Rio de Janeiro: Zahar Ed., 1983.

LICHTENSTEIN, H. The dilemma of human identity. New York: Jason Aronson, 1977.

LIENHARD, Martín. Los testemonios populares y la cuestión de su lectura. Cuadernos de Literatura, vol.38, La Paz: Casa montes, 2001.

LIPOVETSKY, Gilles. Os tempos hipermodernos. São Paulo: Ed. Barcarolla, 2004.

LÖWY, Michael. Origens sócio-religiosas do Movimento dos Trabalhadores Sem Terra do Brasil. In Revista Cultura Vozes, n.3, 2000, pp. 12-20.

. A mística da revolução, FSP, 02/04/2001, Caderno Mais!, p. 16 .

- (org). O marxismo na América Latina: uma antologia de 1909 aos dias atuais. São Paulo: Ed. Fundação Perseu Abramo, 2003. - Do Capitão Swing a Pancho Villa: resistências camponesas ao capitalismo na historiografia de Eric Hobsbawm. MIMEO, s/d p. $1-10$.

MANGANARO, Patrizia. Alteridade, filosofia, mística: entre fenomenologia e epistemologia. Disponivel em 
http://www.fafich.ufmg.br/ memorandum/artigos06/artigo01. pdf, acessado em 12/07/06.

MARCON, Telmo. Acampamento do Natalino: história da luta pela reforma agrária. Passo Fundo: Ediupf, 1997.

MARCUS, G. E. A estética do trabalho de campo contemporâneo em Arte e Antropologia, apresentação no Simpósio Internacional Tradução e percepção - Ciências Sociais em diálogo. Disponivel em http://www.lisa.usp.br/simposio, acessado em 20/09/06.

MARTINS, José de Souza. A militarização da questão agrária. Terra e poder: o problema da terra na crise politica. Petrópolis/RJ:

Vozes, 1985.

- Expropriação e violência, a questão politica no campo. São Paulo: Hucitec, 1980.

. A militarização da questão agrária no Brasil. Petrópolis: Vozes, 1981.

. Os camponeses e a politica no Brasil. Petrópolis: Vozes, 1981. - A reforma agrária e os limites da democracia na "Nova República". São Paulo: Hucitec, 1986.

. Não há terra para plantar neste verão. Petrópolis: Vozes, 1986.

. O cativeiro da terra. São Paulo: Hucitec, 1986.

. Caminhada no chão da noite. São Paulo: Hucitec, 1989.

- A chegada do estranho. São Paulo: Hucitec, 1993.

. O poder do atraso - ensaios de sociologia da história lenta. São

Paulo: Hucitec, 1994.

MATOS, Olgária. Narrativa: metáfora e liberdade. In: história Oral. São Paulo: No. 4 junho de 2001, pp. 9-24.

MAUSS, Marcel \& HUBERT, Henri. Sobre o sacrificio. São Paulo: Ed. Cosac Naify, 2005.

McCONKEY, James. The anatomy of memory: an anthology. New York: Oxford University Press, 1996.

MEAD, George Herbert. Mind, Self, and Society. Chicago: University of Chicago Press, 1934.

MEIHY, José Carlos S. B. A colônia brasilianista: história oral de vida acadêmica. São Paulo: Nova Stella, 1990.

\& Levine, R. M. Cinderela Negra. A Saga de Carolina Maria de Jesus. Rio de Janeiro: UFRJ, 1994.

- Canto de morte Kaiowá: história oral de vida. São Paulo: Edições Loyola, 1991. (org). (Re)introduzindo a história oral no Brasil. São Paulo: Xamã, 1996. . Manual de história oral. São Paulo: Edições Loyola, 2002 e 2005. . La radicalización de la historia oral. In: Palabras e silencios. Revista de la Asociación Internacional de Historia Oral. Nueva Época, vol 2, n. 1, junio 2003, pp. 33-45.

. Augusto e Lea: um caso de (des)amor em tempos modernos. São Paulo: Editora Contexto, 2006.

MENESES NETO, Antônio Julio de. Além da terra: cooperativismo e trabalho na educação do MST. Rio de Janeiro: Quartet, 2003. 
MONTE-MÓR, Patrícia. Sobre antropologia e imagem. IN: ABA, no 31, Museu Nacional, Departamento de Antropologia, 1999, p.15.

MOREIRA, Ruy. Formação do espaço agrário brasileiro. São Paulo: Brasiliense, 1990.

MORIN, Edgar. Ciência com consciência. Rio de Janeiro: Bertrand Brasil, 2005.

MORISSAWA, M. A história da luta pela terra e o MST. Expressão popular, São Paulo. 2001.

MST. Caderno de Educação, n 11 . Educação de jovens e adultos: sempre é tempo de aprender. São Paulo: Iterra, 2003.

MUNANGA, Kabengele. $\mathrm{O}$ anti-racismo no Brasil. In: MUNANGA, K. (org.). Estratégias políticas de combate à discriminação racial. São Paulo: Edusp, 1996.

NADER, Ana Beatriz. Os autênticos do MDB. História Oral de Vida Politica. Petrópolis: Paz e Terra, 1998.

NASCIMENTO, Evando (org.). Jacques Derrida: pensar a desconstrução. São Paulo: Estação Liberdade, 2005.

NORA, Pierre. Entre memória e história: a problemática dos lugares. In: Projeto história, no 10. São Paulo, PUC-SP, dezembro de 1993.

OLIVEIRA, Ariovaldo Umbelino. Modo capitalista de produção $e$ agricultura. São Paulo: Ática, 1995.

. Geografia das lutas pela terra no Brasil. São Paulo: Contexto, 1996.

- A longa marcha do campesinato brasileiro: movimentos sociais, conflitos e reforma agrária. Estudos Avançados / Universidade de São Paulo. Instituto de Estudos Avançados, volume 15, número 43, São Paulo: IEA, setembro/dezembro 2001.

OLIVEIRA, Francisco. Os direitos do antivalor. Petrópolis: Vozes, 1998.

OUTHWAITE, W. e BOTTOMORE, T. (orgs). Dicionário do pensamento social do século XX. Rio de Janeiro: Jorge Zahar, 1996.

PAIERO, D. \& DAMATTO JR., J. R. Foices e Sabres. A história de uma ocupação dos sem-terra. São Paulo: Anna Blume, 1996.

PALADIM JÚNIOR, Heitor Antônio. Insurreição dos saberes, territorialização e espacialização do MST: um estudo de caso da Escola Agricola 25 de maio - Fraiburgo/SC. O ensino de geografia em questão. Dissertação de Mestrado. São Paulo: Dep. de Geografia FFLCH/USP, 2004.

PATAI, Daphene. Brazilian Women Speak. New Brunswick: Rutgers University Press, 1988. . \& GLUCK, S. B. Women's Words. The Feminist Practice of Oral History. New York/London: Routledge, 1991.

PEIRANO, Mariza. Riruais ontem e hoje. Rio de Janeiro: Jorge Zahar Editor, 2003, p.9.

PIZETTA, A. J. Formação e práxis dos professores de escolas de assentamentos: A experiência do MST no Espirito Santo.

(Dissertação de Mestrado). Educação, Universidade Federal do Espírito Santo, 1999. 
PLUMMER, Ken. Identidade. In: OUTHWAITE, W. e BOTTOMORE, T. (orgs.). Op. Cit., p. 369, citando ERIKSON, E. Identity: youth and crises. S/d, 1968, p.31.

POLLAK, Michael. Memória e identidade social. In: Estudos Históricos, Rio de Janeiro, vol. 5, ano 10, 1992, pp.200-212. - Memória esquecimento, silêncio. In: Estudos Históricos. Rio de Janeiro, vol. 2, n. 3, 1989, pp. 3-15.

PORTELLI, Alessandro. The death of Luigi Trastulli and other stories: form and meaning in oral history. Albany: N.Y., SUNY Press, 1991.

Elogio de la grabadora: Gianni Bosio y los orígenes de la historia oral. Revista história 30, México: Abril 1993 Septiembre 1993, pp. 3-8.

- Sonhos ucrônicos: memórias e possiveis mundos dos trabalhadores. IN: Projeto história. Revista do programa de Estudos Pós-Graduados em história e do departamento de história da PUC/SP. São Paulo: EDUC, n. 10, dez 1993, pp. 4158.

- O que faz a história oral diferente. Projeto História, São Paulo:

(14) fev. 1997, pp. 31-32.

. Tentando aprender um pouquinho. Algumas reflexões sobre a ética na história oral. Projeto História, $\mathrm{n}^{\circ} 15,1997$, pp. 13-50.

QUEIROZ, Maria Isaura Pereira de. Messeanismo no Brasil e no mundo. São Paulo: Alfa-Omega, 2004.

RANCIĖRE, Jacques. O dissenso. In: NOVAES, Adauto (org). A crise da razão. São Paulo: Cia das letras, 1996, pp.367-382.

. O desentendimento: política e filosofia. São Paulo: Editora 34, 1996.

Revista Estudos Avançados, no 31. São Paulo: IEA, set/dez de 1997, pp. 7-36.

Revista NEHO-História. São Paulo: $\mathrm{n}^{\circ}$ 0, Núcleo de Estudos em História Oral/USP, 1998.

Revista NEHO-História. São Paulo: $\mathrm{n}^{\circ}$ 1, Núcleo de Estudos em História Oral/USP, nov/ 1999.

RIBEIRO, Darcy. O Povo Brasileiro: A formação e o sentido do Brasil. Companhia das Letras. São Paulo. 1996.

RIBEIRO, Suzana L. S., MEIHY, J. C. S. B. e SANTOS, A. P. dos. Vozes da marcha pela terra. São Paulo: Loyola, 1998.

- Processos de mudança no MST: história de uma família cooperada. São Paulo, Dissertação de Mestrado DH/FFLCH, 2002.

(et al.) Adolescentes: sujeitos da escolarização, In: MST. Alternativas de escolarização dos adolescentes em assentamentos e acampamentos do MST. Coleção cadernos Iterra, Ano III, $\mathrm{n}^{\circ}$ 8, novembro de 2003.

. Engenheiro Maia: o dia a dia de conquistas de uma escola. IN:

Cadernos do Iterra "Alternativas de escolarização dos

adolescentes em assentamentos e acampamentos do MST" -

Veranópolis - RS; Iterra, 2003, p.121-144. 
(org) 20 anos de Educação. Boletim de Educação do Movimento dos Trabalhadores Rurais Sem Terra, no 09. São Paulo: MST, 2004.

, IOKOI, Zilda, ANDRADE, Marcia e REZENDE, Simone. Vozes da terra: histórias de vida dos assentados rurais de São Paulo. São Paulo: Fundação ITESP/ Imprensa Oficial, 2005.

RODOLPHO, Adriane Luisa. Rituais, ritos de passagem e de iniciação: uma revisão da bibliografia antropológica. In: Estudos Teológicos, v. 44, n. 2, p. 138-146, 2004, p. 143.

RODRIGUES, Arakcy M. Operário, operária: estudo exploratório sobre o operariado industrial da grande São Paulo. São Paulo: Símbolo, 1978.

ROMEIRO, A. (et al.) (orgs.). Reforma agrária, produção, emprego e renda. Relatório da FAO em debate. Petrópolis: Vozes, 1994.

RORTY, Richard. Verdade e Progresso. São Paulo: Manole, 2005.

ROSALDO, Renato. Culture and Truth: the ranking of social analisys. Boston: Beacon Press, 1989.

SAMPAIO, Plínio de Arruda. A mistica. Disponivel em: http: / /www.landlessvoices.org/vieira/archive05.phtml?rd=MSTICAOF657\&ng=p\&sc $=3 \&$ th $=42 \& \mathrm{se}=0$, acessado em 18/04/07.

SANTOS, Andrea Paula dos. Ponto de vida, cidadania de mulheres faveladas. São Paulo, Ed. Loyola, 1996. - À Esquerda das Forças Armadas Brasileiras: histórias de vida de militares de esquerda. São Paulo: DH-FFLCH-USP, 1998. - Reforma agrária entre a polarização a negociação e o conflito: resistência e participação do MST nos governos do PT do MS e do RS (1999-2002). Tese de doutorado. São Paulo: DH/FFLCH/USP, 2003.

SANTOS, Boaventura de Sousa. A crítica da razão indolente. Contra o desperdicio da experiência. São Paulo: Cortez, 2002. . Um discurso sobre as ciências. São Paulo: Cortez editora, 2005.

SANTOS, Myrian Sepúlveda. A luta da memória contra o esquecimento. In: Sintese Nova Fase 25, n. 82, 1998, pp. 351-368. . História e Memória: o caso do Ferrugem. In: Revista Brasileira de história, vol.23, no 46. São Paulo: 2003, disponível em: http://www.scielo.br/scielo.php?script=sci_arttext\&pid=S010201882003000200012 , acessado em 10/01/2007.

SARLO, Beatriz. Cenas da vida pós-moderna: intelectuais, arte e vídeocultura na Argentina. Rio de Janeiro, Ed. UFRJ, 1997.

- Tempo passado: cultura da memória e guinada subjetiva. São Paulo: Companhia das Letras, Belo Horizonte: Editora UFMG, 2007.

SELIGMANN-SILVA, Márcio (org). História, memória, literatura: o testemunho na Era das Catástrofes. Campinas: Ed. Unicamp, 2003.

SILVA, Maciel Henrique e SILVA, Kalina Vanderlei. Dicionário de conceitos históricos. São Paulo: Ed. Contexto, 2005. 
SILVA, Vagner Gonçalves da. O antropólogo e sua magia: trabalho de campo e texto etnográfico nas pesquisas antropológicas sobre religiões afro-brasileiras. São Paulo: EDUSP, 2006.

SOTO, Angel. Historia y In: http://www.angelsoto.cl/2006/02/ historia_y_memoria.html, acesso em 10/01/07.

STÉDILE, João Pedro e GÖRGEN, Frei Sérgio. A luta pela terra no Brasil. São Paulo, Editora Página aberta, 1993. - A questão agrária hoje. Porto Alegre: Editora Universidade Federal do Rio Grande do Sul, 1994. (org.) A Reforma Agrária e a luta do MST. São Paulo: Vozes, 1997.

- Questão Agrária no Brasil. São Paulo, Atual, 1997.

e FERNANDES, B. M. Brava gente: a trajetória do MST e a luta pela terra no Brasil. São Paulo, Perseu Abramo, 1999.

STOLL, David. Rigoberta Menchú and the story of all poor Guatemalans. Boulder: Westview Press, 1999.

STREY, Marlene Neves (et al.). Psicologia social contemporânea: livrotexto. Petrópolis-RJ: Vozes, 1998

TAKAU JR, Iokisa. Escola itinerante: escola, Estado e MST no espaço do acampamento. Trabalho de Graduação. São Paulo: DG-FFLCHUSP, 2005.

TAUSSIG, M. Mimesis and Alterity - a particular history of the senses. Routledge. New York and London, 1993.

TÉTART, Philippe. Pequena história dos historiadores. Bauru/SP: Edusc, 2000.

THOMPSON, Edward. P. A miséria da teoria ou um planetário de erros. Rio de Janeiro, Ed. Zahar, 1981.

THOMPSON, Paul. A voz do passado. São Paulo: Paz e Terra, 1998.

THYE, Shane R. \& LAWLER, Edward J. Social identification in groups. New York: Elsevier Jai, 2005, p. 153.

TODOROV, Tzvetan. Nós e os outros: a reflexão francesa sobre a diversidade humana. Rio de Janeiro: Jorge Zahar, 1993.

VEYNE, Paul. Como se escreve a história e Foucault revoluciona a história. Brasília: Ed. UNB, 1998.

VIEZZER, Moema. Se me deixam falar... Domitila - Depoimento de uma mineira boliviana. São Paulo: Ed. Global, 1984.

VILANOVA, Mercedez. Las Mayorias Invisibles. Explotación fabril, Revolución y represión. Barcelona: Icaria/Antrazyt, 1997.

WEIL, Simone. A condição operária e outros estudos sobre a opressão. 2a . ed., Rio de Janeiro: Paz e Terra, 1996.

WHITE, Hayden. Metahistória. A imaginação histórica no século XIX. São Paulo: EDUSP, 1992.

WHITE, Hayden. Trópicos do discurso: ensaios sobre a crítica da cultura. São Paulo: EDUSP, 2001.

YAZBECK, Maria Carmelita. A politica social brasileira nos anos 90: a refilantropização da questão Social. In: Cadernos Abong. São Paulo: Abong, 1995. 
YOW, Valerie Raleigh. Recording Oral History: a guide for the humanities and social sciences. Walnut Creek, CA: AltaMira Press, 2005.

ZELDIN, Theodore. Uma história intima da humanidade. Rio de Janeiro/São Paulo: Ed. Record, 1996. 